insuream Flows Needed for Successful Migration and Rearing of Rainbow and Westslope Cutthroat Trout in Selected Tributaries of the Kootenai River
US. Department of Energy Bonneville Power Administration Division of Fish \& Willite

Montana Department of Fish, Willife and Parks

\section{December 1986}

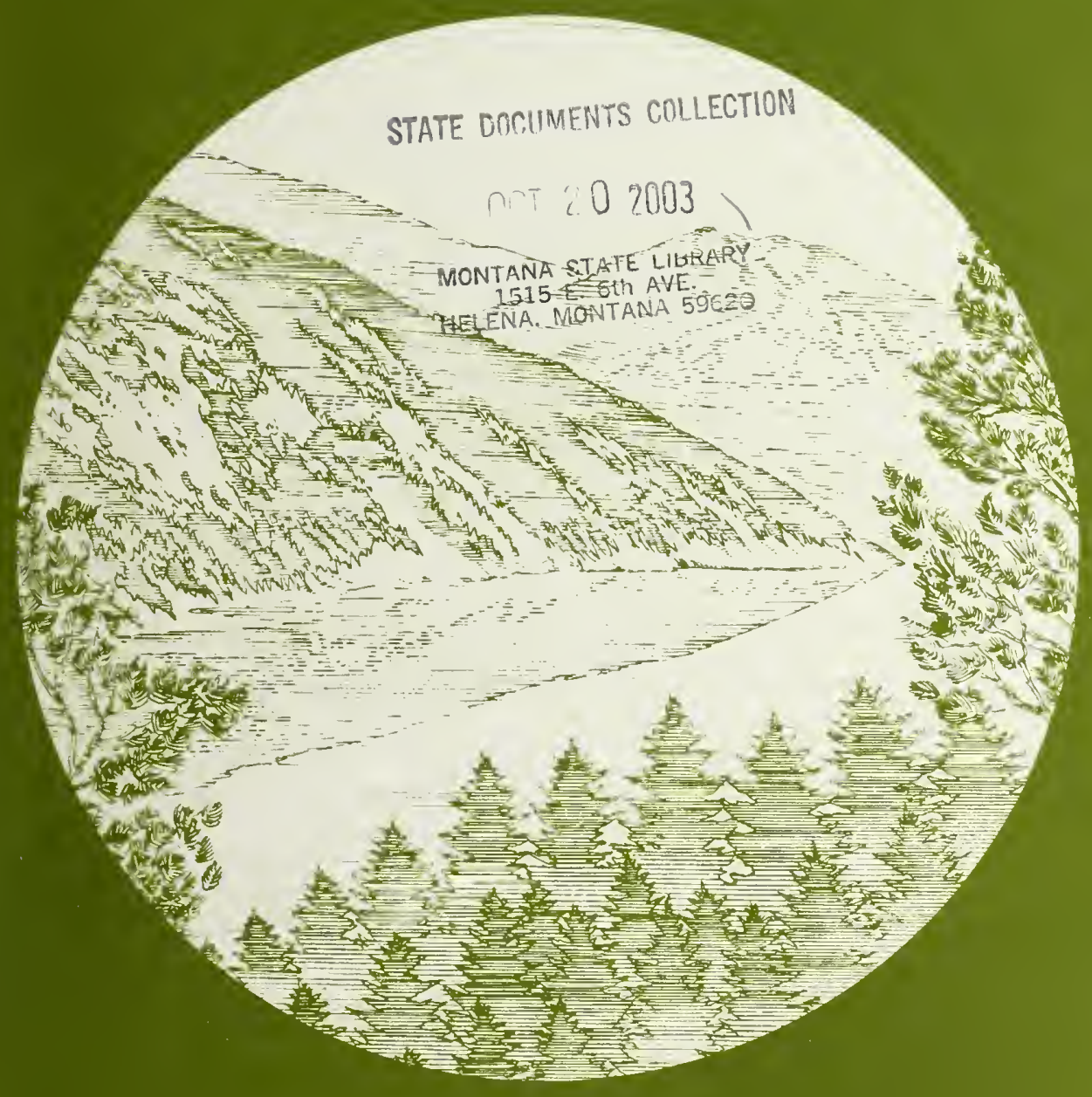


This report was funded by the Bonneville Power Administration (BPA), U.S. Department of Energy, as part of BPA's program to protect, mitigate, and enhance fish and wildlife affected by the development and operation of hydroelectric facilities on the Columbia River and its tributaries. The views in this report are the author's and do not necessarily represent the views of BPA.

For copies of this report, write:

$$
\begin{gathered}
\text { Bonneville Power Administration } \\
\text { Division of Fish and Wildlife } \\
\text { Public Information Officer - PJ } \\
\text { P.O. Box } 3621 \\
\text { Portland, OR } 97208
\end{gathered}
$$

DATE DUE

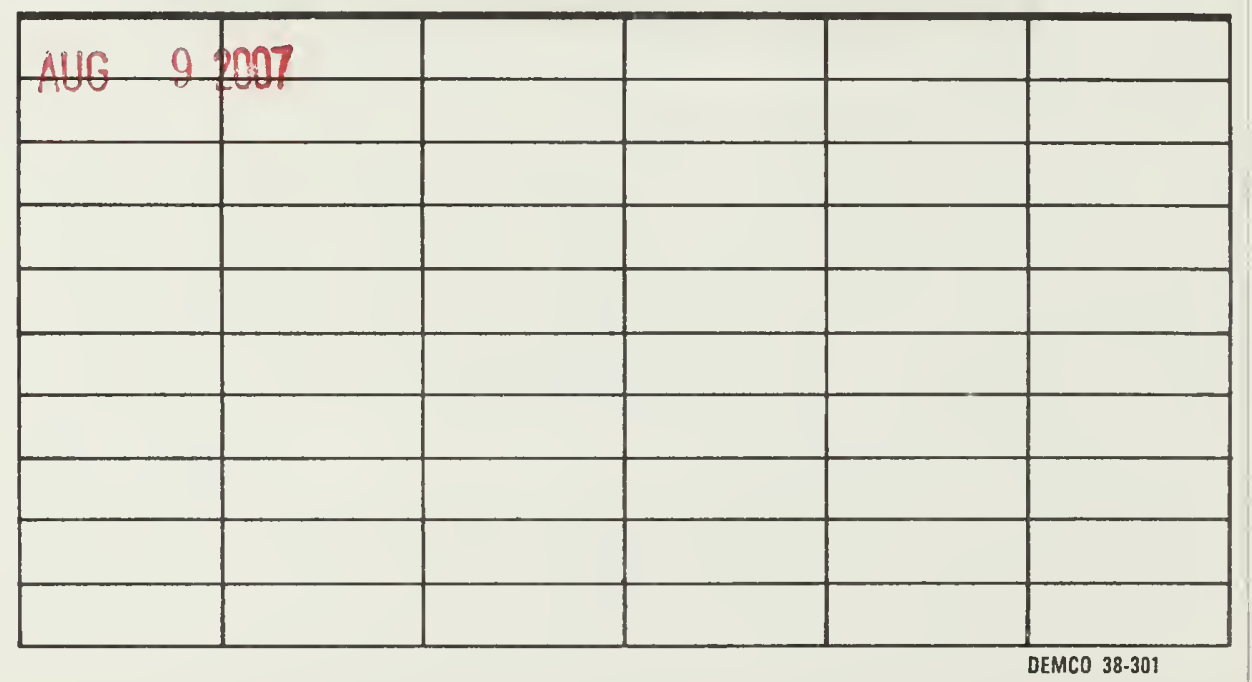


INSTREAM FLOWS NEEDED

FOR SUCCESSFUL MIGRATION SPAWINING AND REARING

OF RAINBOW AND WESTSLOPE CUITHROAT TROUT

IN SETEETED TRIBUIARIES OF THE ROOIENAI RIVER

Final Report 1986

\author{
Prepared by: \\ Brian Marotz - Project Biologist \\ John Fraley - Project Coordinator \\ Montana Department of Fish, Wildlife and Parks \\ P.O. Box 67 \\ Kalispel1, MT 59903
}

Prepared for:

Fred Holm, Project Manager

United States Department of Energy

Bonneville Power Administration

Division of Fish and Wildlife

P.O. BOx 3621

Portland, OR 97208

Contract Number: DE-AI79-85BP23666

Project Number: BPA 85-6 


\section{Digitized by the Internet Archive}

in 2013 


\section{ACKINOWLEDGFMFNIS}

Michael J. Stermitz and John Sullivan assisted in project development and data collections during the first field season. Michael also compiled pertinent text and data useful for completing this document. Barry Hanson and Steve Tralles assisted in the instream flow measurements, migrant trapping and electrofishing during the second field season. Barry deserves recognition for manning the Quartz Creek trap for most of the final four months of the project, and for his work on the stream maps. Steve was responsible for a great share of data entry and computer graphics. David Ellis volunteered his time to assist in electrofishing operations on the Fisher River. They played a major role in this project's success. The reservoir project crew, Paul Hamlin, Nicholas Hetrick, Mark Schafer, Mark Sweeney and Kathleen Walker assisted in stream surveys, electrofishing and Bristow Creek migrant fish trapping. Special thanks to Ian Chisholm, Pat Clancey and Bruce May who provided invaluable discussion and advice. Fred Nelson and Larry Peterman contributed in the analysis and legal aspects of instream flow reservations, respectively. Joe Huston and Jim Vashro provided technical assistance and background information. Thanks also to U.S. Forest Service personnel, Gary Altman, Al Bratkovich, Bob Klarich and John Lloyd who aided in redd surveys and migrant fish assessment. Finally, thanks to Pat Hume of Fortine for diligently noting water stage heights from our Deep Creek staff gauge. 



\section{EXECUITVE SUMMARY}

This study was conducted by Montana Department of Fish, Wildlife and Parks in contractual agreement with Bonneville Power Administration and addresses measure 804(a)(9) of the Northwest Power Planning Council's Columbia River Basin Fish and Wildlife Program. Objectives were to determine instream flow needs in Kootenai River tributaries to maintain successful fish migration, spawning and rearing habitat of game fish, evaluate existing resident and rearing fish populations, and compile hydrologic and fishery information required to secure legal reservation of water for the fishery resource.

The Kootenai River fishery is threatened by microhydro and other water use development which reduce tributary habitat critical for maintaining a healthy spawning and rearing environment. The wetted perimeter method was used to estimate flows required to provide the maximum amount of spawning, rearing and food production area to maintain present $\mathrm{fish}$ populations in 20 tributaries to the Kootenai River and two to the Clark Fork River. Migrant passage flows were determined using the same method based on a discharge - average depth relationship at four (usually five or more) riffle transects. This information will provide the basis to reserve water through application to the Montana Department of Natural Resources and Conservation.

Electrofishing in stream reaches where instream flow measurements were made indicates the relative recruit production value of the various streams. Of all reservoir tributaries investigated, Bristow Creek contained the greatest number of trout (Salmo spp. $\geq 75 \mathrm{~mm})$ per $\mathrm{km}(1,179 \pm 143)$. Quartz Creek, containing an estimated $853 \pm 438$ Salmo spp. ( $275 \mathrm{~mm}$ ) per $\mathrm{km}$, ranked highest among the main stem Kootenai River tributaries. The location of some sampling sections within low stability channels near the tributary mouths may have resulted in underestimates of fish populations further upstream. Westslope cutthroat trout comprised a greater percentage of the Salmo population in reservoir tributaries than appeared in Kootenai River tributary samples.

Migrant Salmo spp. utilizing Bristow and Quartz creeks during spring were captured and released through a bi-directional fish trap. Schnabel's multiple census estimate was used to quantify the total migrant populations. An estimated 285 adult fish (range 224 to 336, $\mathrm{P} \geq 0.95)$ migrated into Bristow Creek to spawn. Quartz Creek was used by an estimated 280 migrants (range 177 to 444). The timing of the run corresponded with increasing water temperatures in both creeks. The Quartz Creek run, predominantly rainbow trout, corresponded with peak flows, whereas Bristow Creek migrants, mainly westslope cutthroat trout, entered the creek during declining flows. 
Fluvial bull trout enter spawning areas in Grave, Quartz, and Pipe creeks during fall. A total of 24 large adult bull trout were captured and released while migrating into Quartz Creek. Adults are highly visible while resting in pools and passing over riffles and are vulnerable to predation and poaching. Debris and log jams may pose critical passage problems during low autumn flows.

Kokanee salmon migrated during fall to spawn in the Tobacco River and its major tributaries, Fortine and Grave creeks, as well as the Fisher River and Libby Creek below Libby Dam. No estimate of kokanee recruitment from these tributaries exists. Most kokanee reproduction occurs in Kootenai River tributaries in Canada.

Log and debris jams are obstacles to migrant fish in Barron, Bobtail, Bristow, Deep, Fivemile, Pinkham, Pipe and Quartz creeks. Periodic debris removal may be needed to maintain access to spawning gravels. Partial blockage is desirable to provide cover, and allow pool formation and gravel deposition. A total fish barrier composed of rock at the mouth of Barron Creek should be modified to allow migrant passage during spring.

Sediment pollution and channel instability caused by man's activities in the Kootenai watershed continue to threaten the health of the fishery resource. 
ACKNOWLEDGEMENTS ................ $\frac{\text { Page }}{i \mathrm{i}}$

EXECUTIVE SUMMARY. ............. i ii

LIST OF TABLES .............. . . vi

LIST OF FIGURES. . . . . . . . . . . . . $x$

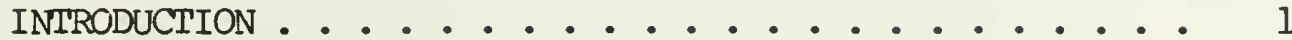

STUDY AREA ....................... 3

METHODS. . . . . . . . . . . . . . 6

Instream Flow Recormendations. . . . . . . . 6

Hydrologic Characteristics . . . . . . . . 6

Water Stage Gauging. . . . . . . . . . 9

Population Estimates ............ 9

Migrant Trapping ............. 11

Spawning Surveys ............. 13

RESULTS AND DISCUSSION ............ 14

Libby Reservoir Tributaries. . . . . . . . 14

Barron Creek............ 14

Big Creek ............. 20

Bristow Creek ........... 27

Deep Creek. . . . . . . . . . . 37

Fivemile Creek. . . . . . . . . . 45

Grave Creek ............. 48

Tobacco River ............ 55

Kootenai River Tributaries ........... 66

Big Cherry Creek. .......... 66

Callahan Creek. . . . . . . . . . 71

Fisher River. . . . . . . . . 78

Libby Creek ............ 83

Quartz Creek............ 93

Wolf Creek. . . . . . . . . . . 106

REANALYSIS OF TRIBUTARIES RESEARCHED BY MAY (1982) • • • 112

RECOMMENDATIONS. . . . . . . . . . . . 134

Instream Flow. . . . . . . . . . . . 134

Fish Populations . . . . . . . . . . 134

Kokanee Spawning . . . . . . . . . . 134

Native Rainbow Trout ............. 135

Fish Barrier Removal ............ 135

Tributary Habitat. . . . . . . . . . 135

LITERATURE CITED .............. 136

APPENDIX A ............... . . A-1

APPENDIX B ................... B-1

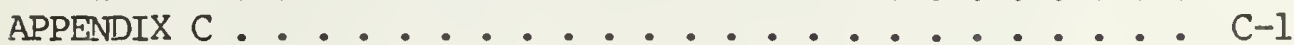





\section{LIST OP TABLES}

Table

Page

1 Trout passage criteria from Wesche and Rechard (1980).

2 The results of a two-pass population assessment conducted in Barron Creek (32N, R29W, Sec. 21) during July, 1985. Discharge approximately 1.9 cfs.

3 Average depth at five riffle transects on Barron Creek at selected flows of interest

4 Results of mark-recapture estimate conducted on Big Creek (T35N, R29W, Sec. 32) during August 1986. Discharge 37.5 cfs.

5 Average depth in five riffle transects on Big Creek at selected flows of interest.

6 Recommended minimum flows for Big Creek and historical water availability records based on ten years of daily records (USGS).

7 The results of a two-pass population assessment conducted in Bristow Creek (T32N, R29W, Sec. 10) during July 1985. Discharge approximately $6.6 \mathrm{cfs}$.

8 Average depth at five riffle cross-sections on Bristow Creek at selected flows of interest.

9 The results of a two-pass population assessment conducted on Deep Creek (T35N, R25W, Sec. 30) during September 1985. Discharge 17.6 cfs.

10 The average depth for 10 riffle cross-sections in Deep Creek at selected flows of interest.

11 The results of a two-pass population assessment conducted on Fivemile Creek (T32N, R28W, Sec. 24) during July 1985. No discharge on record.

12 Average depth at five riffle transects in Fivemile Creek at selected flows of interest.

13 Results of a mark-recapture estimate conducted on Grave Creek (T35N, R26W, Sec. 14, SE-1/4) during September 1986. Discharge $42.8 \mathrm{cfs}$. 
14 Average depich in five riffle transects on Grave Creek at selected flows of interest.

15 Average depth (ft) for five riffle transects in the Tobacco River at selected flows of interest.

16 The average depth for five riffle crosssections in upper Tobacco River at selected flows of interest (May 1982).

17 Recommended minimum flows for the Tobacco River and historical water availability records based on 28 years of daily records (USGS).

18 The average depth for four riffle crosssections on Big Cherry Creek at selected flows of interest.

19 Results of a mark-recapture population estimate conducted in Callahan Creek Creek (T3IN, R34W, Sec. 20) during August 1986. No flow on record.

20 The average depth for nine riffle crosssections on Callahan Creek at selected flows of interest.

21 The results of a mark-recapture population estimate conducted on the Fisher River from Snell Creek to Cow Creek (T28N, R29W, Sec. 12) during August 1986. Discharge $73.4 \mathrm{cfs}$.

22 The average depth for eight riffle crosssections in Fisher River at selected flows of interest.

23 Recommended minimum flows for the Fisher River and historical water availability records based on 18 years of daily records (USGS).

24 Results of a mark-recapture population estimate conducted in Libby Creek (T30N, R31W, Sec. 36) during July 1986. Discharge 27.7 cfs.

25 The average depth for five riffle crosssections in Libby Creek at selected flows of interest. 
26 The average depth for four riffle crosssections in upper Libby Creek at selected flows of interest.

27 Results of a mark-recapture population estimate conducted on lower Quartz Creek (T31N, R32W, Sec. 13) during September 1985. No flow on record.

28 Results of a two-pass population estimate conducted on upper Quartz Creek (T32N, R32W, Sec. 35) during July, 1986. Discharge 8.2 cfs.

29 Captures of Salmo fry in emergence traps set in Quartz Creek (T32N, R32W, Sec. 35) from June 12 through september 2, 1986.

30 The average depth for five riffle transects in Quartz Creek at selected flows of interest.

31 Recommended minimum flows for Wolf Creek and historical water availability records based on ten years of daily records (USGS).

32 The average depths for five riffle transects in Wolf Creek at selected flows of interest.

33 Average depths for five riffle transects on Bobtail Creek at selected flows of interest.

34 Average depths for five riffle transects on the East Fork of the Bull River at selected flows of interest.

35 Average depths for five riffle transects on Fortine Creek at selected flows of interest.

36 Average depths for five riffle transects on O'Brien Creek at selected flows of interest.

37 Comparison of the instream flow recommendations for Pinkham Creek to the approximated median flows of record (May 1982).

38 Average depths for five riffle transects on Pipe Creek at selected flows on interest.

39 Average depths for five riffle transects on Rock Creek at selected flows of interest. 
40 Average depths for five riffle transects of Ross Creek at selected flows of interest.

41 Recommended minimum flows for the Yaak River and historical water availability records based on ten years of daily records (USGS).

42 Average depths for five riffle transects on Young Creek at selected flows of interest. 


\section{LIST OF FIGURES}

Figure

$\underline{\text { Page }}$

1 Relative location of study tributaries to Libby Reservoir and the Kootenai River.

2 A diagram of wetted perimeter.

3 A diagram of the bi-directional fish trapping structure installed in Bristow and Quartz creeks.

4 A map of Barron Creek.

5 An estimated hydrograph for Barron Creek.

6 The wetted perimeter-discharge relationship for five 18 riffle transects on Barron Creek 1985-1986.

7 A map of Big Creek.

8 Mean monthly flows and eightieth percentile exceed23 ence flows based on 10 years of daily stage records for Big Creek (USGS).

9 The wetted perimeter-discharge relationship for five 23 riffle transects on Big Creek 1985-1986.

10 A map of Bristow Creek.

11 An estimated annual hydrograph for Bristow Creek.

12 Length-frequency histograms of Salmo spp. captured while migrating into and out of Bristow Creek during the spring spawning run 1986.

13 Catch direction and distribution over time of migrating Salmo spp. captured at the Bristow Creek trapping structure during spring 1986, and associated water temperatures and stream discharge.

14 The wetted perimeter-discharge relationship for five riffle transects on Bristow Creek 1985-1986.

A map of Deep Creek.

16 An estimated annual hydrograph for lower Deep Creek.

17 The wetted perimeter-discharge relationship for five riffle transects on Lower Deep Creek 1985-1986. 
18 The wetted perimeter-discharge relationship for five riffle transects on upper Deep Creek 1986.

19 Stream discharge derived from stage gauge data for upper Deep Creek, May 16 - September 21, 1986.

20 A map of Fivemile Creek.

21 The wetted perimeter-discharge relationship for five riffle transects on Fivemile Creek 1985-1986.

22 A map of Grave Creek.

23 An estimated annual hydrograph for Grave Creek.

24 The wetted perimeter-discharge relationship for five riffle transects on Grave Creek 1985-1986.

25 A map of the Tobacco River.

26 Mean monthly flows and eightieth percentile exceedence flows based on 28 years of daily stage records for the Tobacco River (USGS).

27 The wetted perimeter-discharge relationship for five riffle transects on the Tobacco River 1985-1986.

28 The wetted perimeter-discharge relationship for five riffle transects on the Tobacco River (May 1982).

29 A map of Big Cherry Creek.

30 Mean monthly flows and eightieth percentile exceedence flows based on ten years of daily stage records for Granite Creek (USGS).

31 The wetted perimeter-discharge relationship for four riffle transects on Big Cherry Creek below the confluence of Granite and Big Cherry creeks 19851986.

32 A map of Callahan Creek.

33 An estimated annual hydrograph for Callahan Creek.

34 The wetted perimeter-discharge relationship for four riffle transects on Callahan Creek below the falls 1985-1986. 
35 The wetted perimeter-discharge relationship for four riffle transects on Callahan Creek above the falls 1986.

36 A map of the Fisher River showing the location of transects and other points of interest.

37 Mean monthly flows and eightieth percentile exceedence flows based on 18 years of daily stage records for the Fisher River (USGS).

38 The wetted perimeter-discharge relationship for eight riffle transects on the Fisher River 19851986.

39 A map of Libby Creek.

40 The wetted perimeter-discharge relationship for five riffle transects on Libby Creek 1985-1986.

41 The wetted perimeter-discharge relationship for five riffle transects on Libby Creek (May 1982).

42 A map of Quartz Creek.

43 An estimated annual hydrograph for Quartz Creek.

44 Length-frequency histograms of Salmo spp. captured while migrating into and out of Quartz Creek during the spring spawning run, 1986.

45 Catch direction and distribution over time of migrating Salmo spp. captured during spring 1986, and associated water temperatures and stream discharge.

46 The wetted perimeter-discharge relationship for five 104 riffle transects on Quartz Creek, 1985-1986.

47 A map of Wolf Creek.

48 Mean monthly flows and eightieth percentile exceed- 108 ence flows based on 10 years of daily stage records for Wolf Creek (USGS).

49 The wetted perimeter-discharge relationship for five 108 riffle transects on Wolf Creek 1985-1986.

50 The wetted perimeter-discharge relationship for five riffle transects on Bobtail Creek (May 1982). 
51 The wetted perimeter-discharge relationship for five riffle transects on the East Fork of the Bull River (May 1982).

52 The wetted perimeter-discharge relationship for five 116 riffle transects on Fortine Creek (May 1982).

53 The wetted perimeter-discharge relationship for five 119 riffle transects on O'Brien Creek (May 1982).

54 The wetted perimeter-discharge relationship for five 119 riffle transects on Pinkham Creek (May 1982).

55 The wetted perimeter-discharge relationship for five 123 riffle transects on Pipe Creek (May 1982).

56 The wetted perimeter-discharge relationship for five 123 riffle transects on Rock Creek (May 1982).

57 The wetted perimeter-discharge relationship for five 126 riffle transects on Ross Creek (May 1982).

58 Mean monthly flows and eightieth percentile exceed- 129 ence flows based on 10 years of daily stage records for the Yaak River (USGS).

59 The wetted perimeter-discharge relationship for five 130 riffle transects on the lower Yaak River (May 1982).

60 The wetted perimeter-discharge relationship for five 130 riffle transects on the upper Yaak River (May 1982).

61 The wetted perimeter-discharge relationship for five 132 riffle transects on Young Creek (May 1982). 


\section{INIRODUCTION}

In recognition of the harmful effects of hydropower development on fishery habitat, the Northwest Power Planning Council (1982) under the direction of the Northwest Power Act of 1980, developed a plan "... to protect, mitigate and enhance fish and wildlife, including related spawning grounds and habitat, on the Columbia River and its tributaries." The program was designed to deal comprehensively with the Columbia drainage system; the Kootenai River is the second largest tributary. This final report is the culmination of research funded by the Bonneville Power Administration and performed by the Montana Department of Fish, Wildlife and Parks to address measure $804(\mathrm{a})(9)$ of the Northwest Power Planning Council's Columbia River Basin Fish and Wildlife Program.

The tributaries to the Kootenai River and Libby Reservoir provide critical spawning and rearing habitat for fluvial and adfluvial fish populations which produce one of western Montana's most popular sport fisheries. The Kootenai watershed is a high water-yield drainage and tributaries have been targeted for microhydro and irrigation development, both of which could reduce available habitat required to maintain the fishery resource. Fisheries production in tributary streams is directly proportional to the amount of insect production, bank cover, and fish spawning and rearing habitat, which in turn are proportional to the amount of wetted riffle areas. When discharge declines, stream flow recedes from the banks and riffle areas, reducing available food, and resting and rearing habitat. Thus, the wetted perimeterdischarge relationship is an important parameter in the assessment of fisheries needs (Leathe and Nelson 1986). It is important that instream flow requirements of game fish species be determined so that fisheries needs can be balanced with those required for power and irrigation facilities.

When completion of Libby Dam on the Kootenai River formed Libby Reservoir (Lake Koocanusa), the initial fish management plan was to establish spawning runs of adfluvial westslope cutthroat and other game fish in suitable tributary streams (May et al. 1983). Similarly, the fishery below the dam was to be managed for increased fish size and to maintain critical spawning and rearing habitat in tributary streams (May and Huston 1983). Popular game fish include westslope cutthroat trout, Salmo clarki lewisi; rainbow trout, Salmo gairdneri; bull trout, Salvelinus confluentis (inland Dolly Varden); kokanee salmon, Oncorhynchus nerka; northern mountain whitefish, Prosopium williamsoni; and the burbot, Lota lota. The westslope cutthroat trout and bull trout are considered species of special concern in Montana because of their limited distribution in the state and reduced presence within their original native range. 
Section 210 of the Public Utility Regulatory Policies Act, passed by congress in 1978, created a strong incentive for developing small hydropower facilities (less than 5 megawatts) in the Pacific Northwest by assuring a high market price for energy from qualifying facilities. In response, applications to the Federal Energy Regulatory Commission (FERC) for small hydro facilities increased in the northwest. In July 1986, the Montana Public Service Commission lowered the rate power companies were required to pay for energy from small hydroelectric facilities, making development less attractive. For this reason, many of the original FERC applications for microhydro development in the Kootenai River tributaries were withdrawn or allowed to expire. However, in 1986, four small hydroelectric projects were pending in the Kootenai Drainage of Montana and another small scale generator was recently installed. Further microhydro development is anticipated when the region's energy surplus declines and costbenefit ratios improve, thereby making construction of new projects once again economically attractive. Development of housing subdivisions, irrigated farmland and mining have also increased competition for water-use on important spawning and rearing tributaries (May and Huston 1983). tives:

This project began in August, 1986, with the following objec-

1) Determine instream flows required to ensure successful migration, spawning and rearing of salmonids in selected tributaries to the Kootenai River (Callahan, Granite, Libby, Quartz and Wolf creeks, and the Fisher River) and tributaries to Libby Reservoir (Barron, Big, Bristow, Deep, Fivemile and Grave creeks, and the Tobacco River).

2) Evaluate existing resident and rearing fish populations in the tributary reaches where the instream flow measurements were made, and assess potential barriers to migrant spawners.

3) Compile available hydrologic and fishery information required to secure legal reservation of instream flows on Kootenai River tributaries identified as containing important or sensitive fishery habitat. 


\section{STUDY AREA}

The Kootenai River, the second largest tributary to the Columbia River, originates in Kootenai National Park near Banff, British Columbia. The river enters Montana near Rexford, Montana, flows southward through the Purcell and Salish mountains and enters the reservoir created by Libby Dam. Below the dam at Libby, Montana, the river turns northwest along the Cabinet Mountain range and crosses the Idaho border near Troy, Montana. The Kootenai is approximately $780 \mathrm{~km}$ long and flows into the Columbia River at Castlegar, B.C.

The drainage basin is characterized by north to northwest trending mountain ranges composed of faulted and folded crustal blocks of metamorphosed sedimentary rocks of the Precambrian Belt Series and minor basaltic intrusions. The area is typified by rugged, steep mountain slopes and narrow valleys. As much as 90 percent of the Kootenai basin is coniferous forest; a small amount (about 2\%) is agricultural land used mainly for pasture and forage production (Bonde and Bush 1982).

Of the approximately $49,987 \mathrm{~km}^{2}$ in the Kootenai drainage, runoff from $5,761.7 \mathrm{~km}^{2}$ enters the Kootenai from the thirteen tributaries under invęstigation (Figure 1). Seven Kootenai tributaries $\left(3,289,8 \mathrm{~km}^{2}\right)$ and two tributaries to the Clark Fork drainage $\left(155.1 \mathrm{~km}^{2}\right.$ ) investigated by May (1982) were reanalyzed. Further tributary descriptions are included in their respective sections of this report.

The tributaries are characteristically high gradient mountain streams with bed material consisting of various mixtures of sand, gravel, rubble, boulders and differing amounts of clay and silt, predominantly of glacio-lacustrine origin. Fine materials, due to their instability during periods of high stream discharge, are continually abraded and redeposited as gravel bars, forming braided channels with alternating riffles and pools.

Siltation and dewatering are major threats to the aquatic habitat in the tributaries. Siltation has been increased by timber harvest, mining, poor agricultural practices, and road construction. A high percentage of fine material in the streambed, unless removed from the gravels by dominant discharge flows, can be deleterious to the spawning habitat, and egg and fry survival (Peters 1962).

Stream flow in unregulated tributaries generally peaks in May and June after the onset of snow melt, then declines to low flows from November through March. Natural low flows during autumn and winter months combined with surface, anchor and frazil ice, as well as channel scouring during ice-out in spring can be especially damaging to fish and fish habitat. For this reason, water withdrawals during this time may have a greater impact on the already stressed fish populations. Decreasing flows during summer 


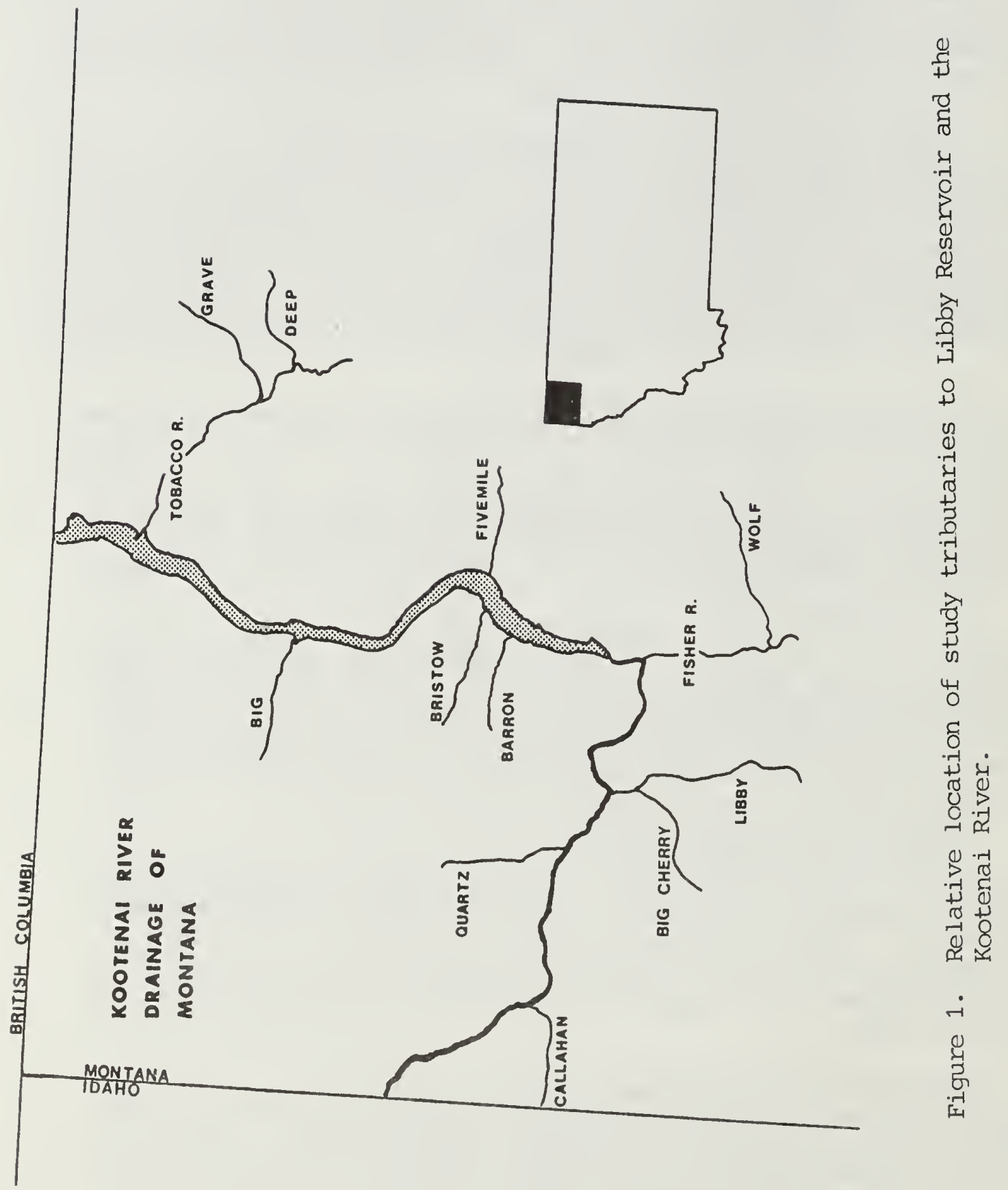


increase water temperature and reduce the amount of cover available to rearing young. Extremely low flows may strand adults and young recruits in rapidly warming pools. Therefore, if trout populations are to be maintained at present levels, it is necessary to discontinue water removal when flows fall below the recommended flow. 


\section{METHODS}

\section{Instream Flow Recommendations}

The wetted perimeter method described by Nelson (1980) was used to determine instream flows needed to maintain existing fish populations and provide adequate passage for spawning migrants. A minimum of four (usually five or more) permanent transects were established across representative riffles in each tributary. Discharge in cubic feet per second (cfs) was measured at low, medium and high stream discharge using a Teledyne Gurley Type AA or Pigmy water velocity meter, depending on water depth (Type AA for water $>1 \mathrm{ft}$ and Pigmy for water <l ft deep). Water velocities were measured at approximately 20 or more stations positioned along each transect. Measurements were made at a standard depth $\mathbf{0 . 6}$ total depth) at each station. At stations deeper than $2.5 \mathrm{ft}$, calculations were based on the average of velocities measured at 0.2 and 0.8 of measured depth. The product of area and water velocity produced stream discharge within each width-depth "cell" along the transect. The sum of discharge in all cells equals total stream discharge.

Water stage and transect profile elevations were determined relative to an established bench mark with a level and stadia rod (Nelson 1984).

Three or more stage-discharge coordinates were linearly regressed on a logarithmic scale to develop a stage-discharge relationship for each riffle transect. Channel profile measurements combined with predicted water stage heights at selected stream discharges yielded accurate estimates of wetted perimeter, that portion of streambed in contact with water (Figure 2). Inflection points, identified from a plot of the curvilinear relationship between discharge and wetted perimeter, and criteria developed by Nelson (1980) were used for recommending stream flows required for maintenance of the fishery. Water depths, over critical riffle features, predicted by the wetted perimeter program (WETP) were used in conjunction with fish passage criteria (Table 1) to derive minimum passage flows for migrants.

The IFGl method was not used for comparison with the wetted perimeter method because it involves the use of the Manning equation and a roughness coefficient which are difficult to apply to high-gradient turbulent streams.

\section{Hydrologic Characteristics}

For ungauged streams, mean annual discharge was estimated from a multiple regression equation derived by Parrett and Hull (1985). The following log-linear form, based on 47 stream-flow measuring 


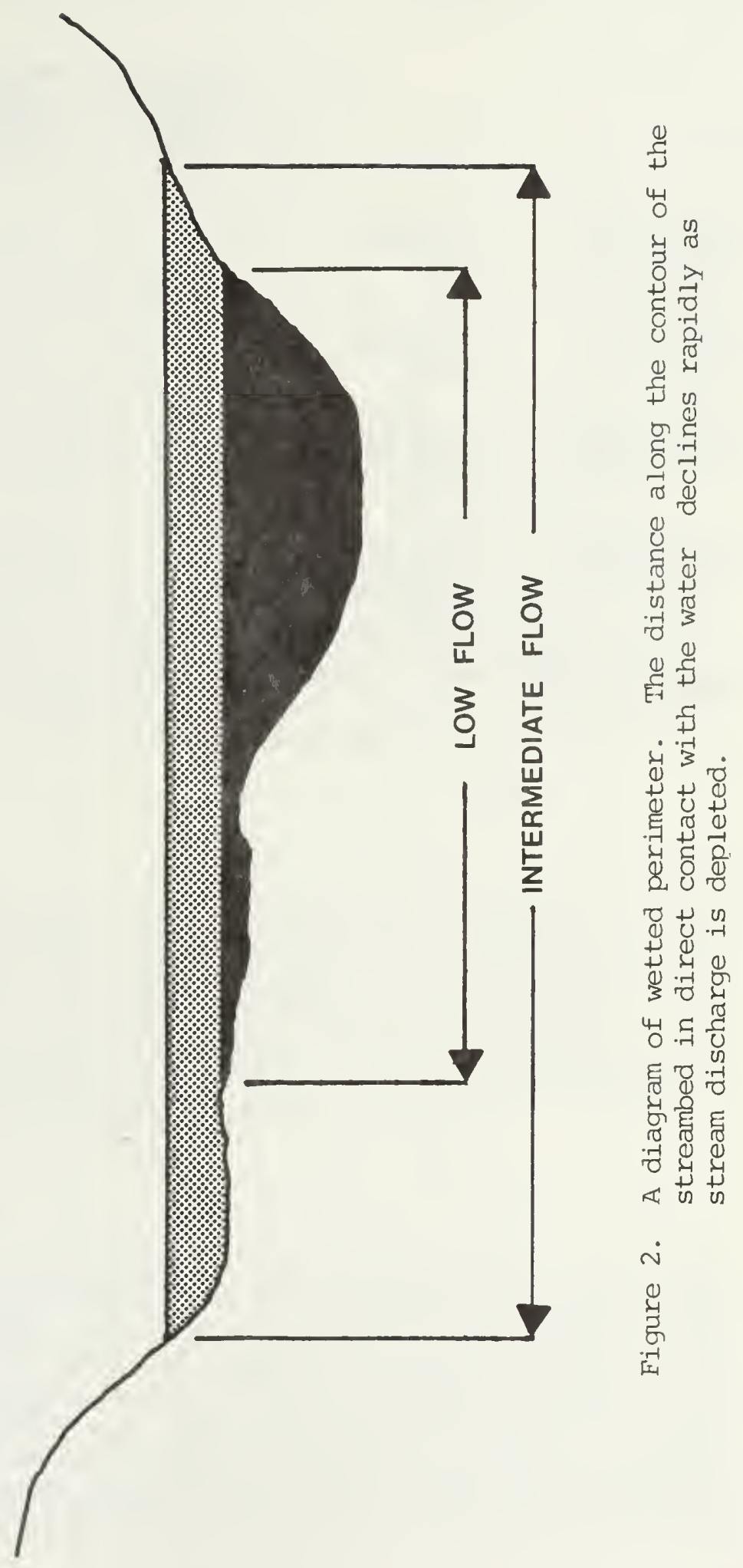


Table 1. Trout passage criteria from Wesche and Rechard (1980).

\begin{tabular}{|c|c|c|c|c|}
\hline Species & Source & $\begin{array}{l}\text { Minimum } \\
\text { depth } \\
\text { (ft) }\end{array}$ & $\begin{array}{l}\text { Average } \\
\text { depth } \\
\text { (ft) }\end{array}$ & $\begin{array}{l}\text { where } \\
\text { developed }\end{array}$ \\
\hline $\begin{array}{l}\text { Large trout } \\
\geq 20 \text { in. }\end{array}$ & $\begin{array}{l}\text { Thompson } \\
1972\end{array}$ & 0.6 & --- & Oregon \\
\hline $\begin{array}{l}\text { Other trout } \\
<20 \text { in. }\end{array}$ & $\begin{array}{l}\text { Thompson } \\
1972\end{array}$ & 0.4 & - & Oregon \\
\hline $\begin{array}{l}\text { Trout streams } \\
>20 \mathrm{ft} \text {. wide }\end{array}$ & $\begin{array}{l}\text { Colorado Div. } \\
\text { of Wildlife } \\
1976\end{array}$ & -- & $\star 0.5-0.6$ & Colorado \\
\hline $\begin{array}{l}\text { Trout streams } \\
10-20 \mathrm{ft} \text {. wide }\end{array}$ & $\begin{array}{l}\text { Colorado Div. } \\
\text { of Wildlife } \\
1976\end{array}$ & -- & $\star 0.2-0.4$ & Colorado \\
\hline
\end{tabular}

* Across riffles 
sites and gauging stations in northwest Montana, has an $r^{2}=0.944$ and a standard error of 33 percent $(p \geq 0.95)$ :

$$
\begin{aligned}
& Q_{A}=0.0165 A^{0.974} \mathrm{P}^{1.159} \\
& \text { Where: } Q_{A}=\text { mean annual dischąrge (cfs) } \\
& A=\text { drainage area }\left(\mathrm{mi}^{2}\right) \\
& \text { and } \mathrm{P}=\text { mean annual precipitation }
\end{aligned}
$$

(from U.S. Soil Conservation Service 1977)

Tributary drainage areas (A) were determined using standard USGS topographic maps ( 1 in $=1 \mathrm{mi}$ scale) and an electronic planimeter. Drainage area was measured repeatedly until the results compared within 0.01 perçent $\left(\mathrm{mi}^{2}\right)$ and the mean of successive trials was converted to $\mathrm{km}^{2}$. The precipitation portion of the equation (P) was based on average annual precipitation from 1941 through 1970 in each watershed (U.S. Soil Conservation Service 1977). Mean annual discharge and eightieth percentile exceedence flow hydrographs were developed for all gauged streams based on a minimum of 10 years of daily readings compiled by the USGS Water Resources Division, Helena, Montana. Annual hydrographs for ungauged streams were estimated by comparing available discharge measurements to concurrent measurements at gauged streams exhibiting the same general hydrologic setting as the site in question (Parrett and Hull 1985). Flow recommendations, based on the results of the wetted perimeter analyses, were compared with base flows derived from existing data to determine applicable minimum flow limits throughout the year.

\section{Water Stage Gauging}

Standard staff gauges were installed in protected areas on Bristow, Deep and Quartz creeks in April 1986. Discharge measurements made at various low, medium and high flows were correlated with water heights read from the staff gauges to develop a loglinear stage-discharge relationship. Stage readings were later transformed to discharge (cfs) based on an algorithm unique to each gauge and associated stream profile.

\section{Population Estimates}

Fish population estimates were intentionally performed during late summer and fall to avoid the capture of Salmo spp. during their spawning run and to target resident and pre-emigrant fish. The timing of the estimate reduces the chance of violating the assumption of a closed population and produces results more comparable from year to year. Electrofishing population estimates were reported in number of $\mathrm{fish}$ per $\mathrm{km}$ based on surveyed sections in all tributary creeks. A 2,000-ft section was surveyed on the Tobacco River and a 15,820-ft section was electrofished on the Fisher River. 
The electrofishing method used depended on the discharge of the stream. Estimates on small tributaries $(\leq 20 \mathrm{cfs})$ were made using a two-sample method explained by Seber (1973). Each sample consisted of an intensive electrofishing effort within a 100-m to $300-\mathrm{m}$ section of stream, isolated from the remaining reach by block nets or natural stream features. A three-person crew (2 netters, 1 shocker) using a Coffelt BP-lC gas-powered backpack electrofishing unit, attempted to capture every fish within the measured stream section on each pass. Captured fish were measured and weighed, then retained in a mesh box for the duration of the experiment. A three-sample estimate of population size and variance was calculated using equations $7.23,7.24$, and 7.30 in Seber (1973) when the following criteria were not met in two passes:

$\hat{\mathrm{p}} \geq 0.50$ and $\hat{\mathrm{N}} \geq 50$, or

$\hat{\mathrm{p}} \geq 0.60$ and $\hat{\mathrm{N}} \leq 50$

where: $\hat{p}=$ probability of capture

and $\hat{\mathrm{N}}=$ the fish population estimate

The probability of capture ( $\hat{p})$ was calculated as:

$$
\hat{\mathrm{p}}=\frac{\mathrm{n}_{1}-\mathrm{n}_{2}}{\mathrm{n}_{1}}
$$

The population size $(\hat{\mathrm{N}})$ and variance $(\hat{\mathrm{V}}[\hat{\mathrm{N}}])$ for two-sample estimates were calculated as follows:

$$
\begin{gathered}
\hat{\mathrm{N}}=\frac{\mathrm{n}_{1}^{2}}{\mathrm{n}_{1}-\mathrm{n}_{2}} \\
\hat{\mathrm{V}}[\hat{\mathrm{N}}]=\frac{\mathrm{n}_{1}^{2} \mathrm{n}_{2}^{2}\left(\mathrm{n}_{1}+\mathrm{n}_{2}\right)}{\left(\mathrm{n}_{1}-\mathrm{n}_{2}\right)^{4}}
\end{gathered}
$$

Where: $\mathrm{n}_{1}=$ the number of fish $\geq 75 \mathrm{~mm}$, TL in the first sample, and $n_{2}=$ the number of fish $\geq 75 \mathrm{~mm}$, TL in the second sample.

Fish populations in tributaries with discharges in excess of 20 cfs were estimated with the mark-recapture method presented by Seber (1973). On smaller tributaries, a mark-recapture effort was made using the Coffelt backpack electrofishing unit described earlier. For larger tributaries ( $\geq 35 \mathrm{cfs}$ ), we used a bank shocking unit or a drift shocking boat containing a Coffelt variable voltage pulsator - 3E electroshocker energized by a Homelite gaspowered generator. The resident population was sampled within a 
representative section of stream 300-600 meters in length depending on tributary size. Block nets or natural barriers were used to isolate the measured section. Individual fish were marked with a pelvic, anal or caudal fin punch and released throughout the electrofishing section and allowed to redistribute for a minimum of 72 hours prior to the recapture run.

Population size $(\hat{\mathrm{N}})$ and variance $(\hat{\mathrm{V}}[\hat{\mathrm{N}}])$ for mark-recapture estimates were calculated according to seber (1973).

$$
\begin{aligned}
& \hat{N}=\frac{(M+1)(C+1)}{(R+1)}-1 \\
& \hat{V}[\hat{N}]=\frac{(M+1)(C+1)(M-R)(C-R)}{(R+1)^{2}(R+2)} \\
& \text { and } R=\text { number of marked fish recaptured. } \\
& \hat{C}=\text { number of marked fish }
\end{aligned}
$$

Where: $M=$ number of marked fish

Fish were analyzed by subgroups based on 5-mm length-frequency histograms and capture efficiency curves. A minimum total fish length of $\geq 75 \mathrm{~mm}$ was used for estimates in which all length groups were pooled. Smaller fish were included in estimates where capture efficiency indicated acceptable accuracy in lower length categories. Subgroup estimates were summed to obtain a total population estimate.

\section{Migrant Trapping}

Two bi-directional fish traps were installed approximately 1 $\mathrm{km}$ upstream from the mouth of Bristow and quartz creeks to capture migrants traveling both up and downstream. Individual traps were 122 by 122 by $70 \mathrm{~cm}$ welded metal frames surrounded on all sides and bottom with $12 \mathrm{~mm}$ hardware cloth mesh. An X-shaped arrangement of poultry-mesh leads with $2.54 \mathrm{~cm}$ openings, supported by metal fence posts driven into the streambed, guided fish toward the throat of the traps. Escape was made difficult by a V-shaped baffle extending inward at the front of the trap to a $5.8 \mathrm{~cm}$-wide, vertical slot in the interior. A trap door in the wooden top and minimal internal reenforcement provided easy access to the catch with a dip net. A water scope was used to assure that all fish were removed from the traps. The trap leads were designed to release if water and debris strained the trap structure (Figure 3). Leads were brushed free of debris up to twice daily and 


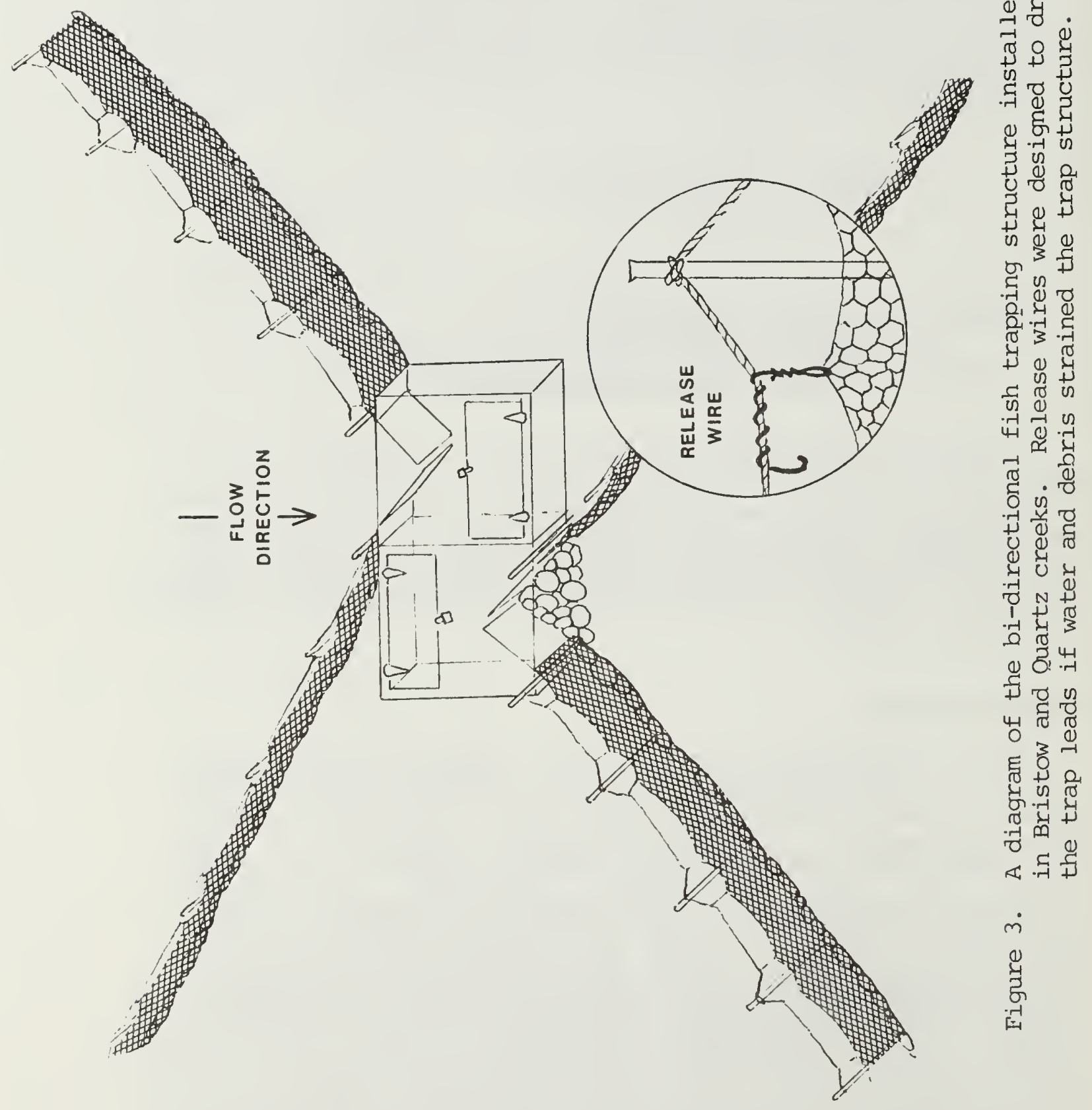


checked with the water scope to maintain trapping efficiency during spring runoff. Catches were standardized to catch-per-day assuming catch rate was constant. Stream discharge and maximumminimum water temperatures were recorded in conjunction with fish catch.

The migrant populations were approximated to the maximum likelihood estimate using Schnabel's multiple census formula modified by Chapman (Ricker 1975):

$$
\hat{N}=\sum \frac{\left(C_{t} M_{t}\right)}{R+1}
$$

Where: $M_{t}=$ the number of marked fish $\geq 180 \mathrm{~mm}$ at large at time $t$,

$$
C_{t}=\text { the number of fish } \geq 180 \text { mm captured at time } t \text {, }
$$

and $\mathrm{R}=$ the number of marked recaptures.

Approximate limits of confidence $(p \geq 0.95)$ for this formula were obtained by considering $\sum R$ as a Poisson variable (Ricker 1977).

\section{Spawning Surveys}

Redds were recorded by survey personnel in Bristow, Grave and Quartz creeks after the spawning run was completed. Redds were listed as definite, probable or possible using criteria described by Shepard et al. (1982). Only those redds classified as "definite" or "probable" were included in the final count. 


\section{RESUISS AND DISCUSSION}

Stream descriptions, population estimates and hydrologic information required for recommending instream flows are presented by stream in two groups: 1) tributaries to Libby reservoir and 2) tributaries to the Kootenai River. Instream flow recommendations by May (1982) were reanalyzed by an updated WETP program and are summarized at the end of this report.

\section{LIBBY RESERVOIR TRIBUTARIES}

Streams entering Libby Reservoir supplement the reservoir fishery through recruitment of the progeny of migrant fish which ascend the tributaries to spawn. These tributaries supply inflowing nutrients from the surrounding watershed and food items such as benthic drift and forage fish. Fish production in the reservoir, therefore, depends greatly on the health of its tributary streams.

\section{Barron Creek}

\section{Description}

Stream reach: Barron Creek from its confluence with the western shore of Libby Reservoir (T32N, R29W, Sec. 27) to the headwaters (T32N, R30W, Sec. 22) (Figure 4).

Stream Length: $10.9 \mathrm{~km}$. Total drainage area: $42.37 \mathrm{~km}^{2}$. Gradient: $\quad 39.6 \mathrm{~m} / \mathrm{km}$.

\section{Source and Land Use}

Barron Creek originates on the southeast slope of the Purcell Mountains and flows east for approximately $11 \mathrm{~km}$ into the western shore of Libby Reservoir. Most of the drainage is in the Kootenai National Forest. All or a portion of five sections of land within the drainage are owned by Champion International. Timber production is the primary land use in the drainage.

\section{Flows}

Little flow data have been collected on Barron Creek except for sporadic measurements taken by personnel of the Kootenai National Forest and Montana Department of Fish, Wildlife and Parks. Miscellaneous measurements were compiled to construct an estimated annual hydrograph for water availability (Figure 5). Estimated mean annual discharge is $14.2 \mathrm{cfs}$. 


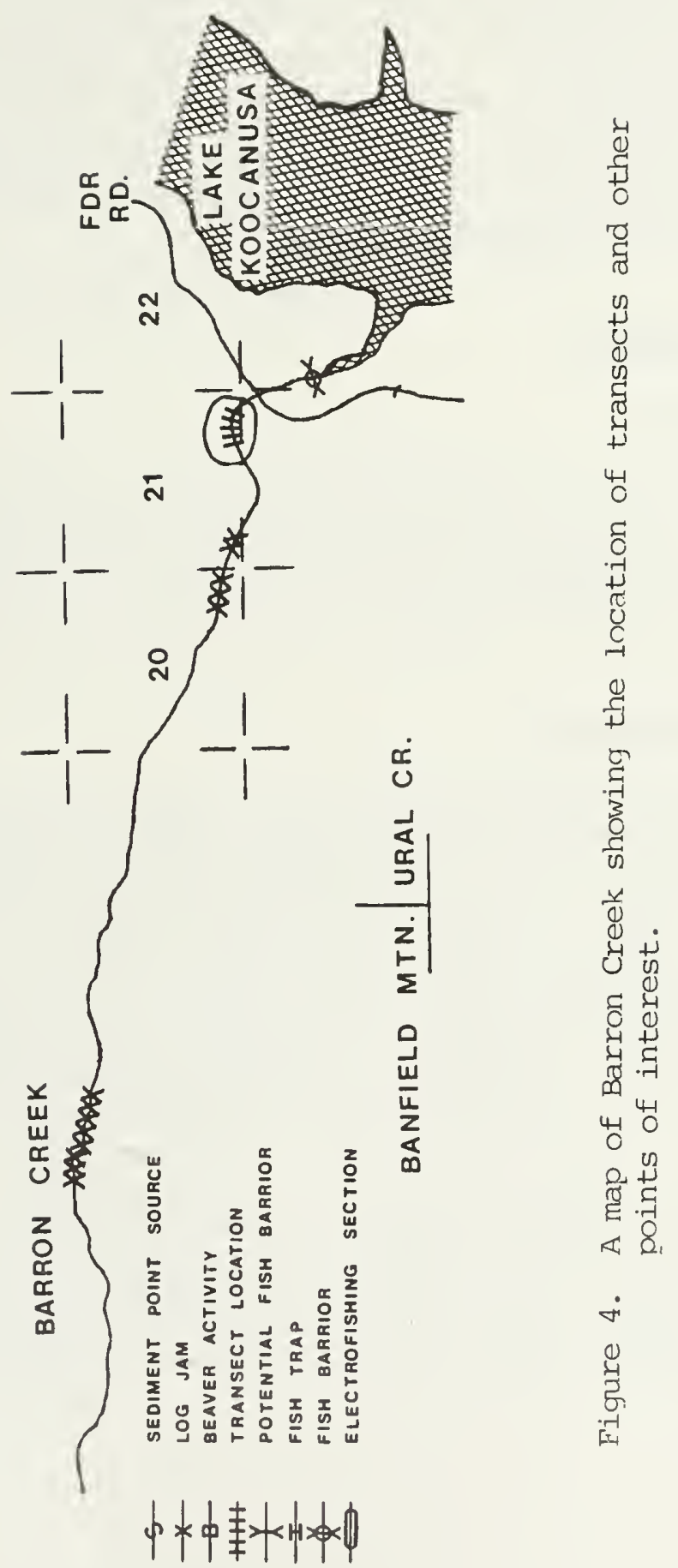


Timber harvesting could increase sediment loading to the system and alter peak flows, causing channel stability problems and damage to fishery habitat.

Original spawning habitat downstream of a rock barrier located within the zone of reservoir surface fluctuation has been inundated. Historical reservoir water elevations are below the height of the rock barrier during the spring spawning period, eliminating Barron Creek as a potential source of rainbow and westslope cutthroat trout recruits to the reservoir. The rock barrier could be modified into a step-like cascade which would allow for migrant passage.

\section{FISH POPULATIONS}

\section{Resident Fish}

The results of a two-pass population assessment conducted within a 108-m blocked-off section of stream revealed that the game fish population in Barron Creek presently consists of eastern brook trout (Appendix Al) and relatively smaller numbers of westslope cutthroat trout and rainbow-cutthroat hybrids (Table 2).

\section{FLON RECOMMENDATIONS}

Five permanent transects were established in riffle areas located approximately $1 \mathrm{~km}$ upstream from the mouth (T32N, R29W, Sec. 21, SE-1/4). The WETP program was calibrated to stage and discharge measurements made at flows of $1.6,3.1,17.7$ and 46.4 cfs. The lower and upper inflection points in a plot of the wetted perimeter-discharge relationship occur at flows of 1 and 2 cfs, respectively (Figure 6). Based on an evaluation of the existing fishery, results of the wetted perimeter analysis and estimated water availability, a discharge of $2 \mathrm{cfs}$ is recommended for the low flow period from July 1 through March 31.

The average depth at the five riffle transects exceeds $0.5 \mathrm{ft}$, the minimum depth estimated for trout passage, at a flow of approximately 12.5 cfs (Table 3). Therefore, a flow of 12.5 cfs is recommended for the period from April 1 through June 30 to ensure passage of spring spawners above the barrier and a possible future spawning run from the reservoir enhanced by barrier removal. 
Table 2. The results of a two-pass population assessment conducted in Barron Creek (T32N, R29W, Sec. 21) during July, 1985. Discharge approximately 1.9 cfs.

\begin{tabular}{lcc}
\hline & $\begin{array}{c}\text { Total Number } \\
\text { Captured }\end{array}$ & $\begin{array}{c}\text { Estimated Number } \\
\text { Fish } \geq 75 \mathrm{~mm} \text { per km }\end{array}$ \\
eastern brook trout & 153 & $1,537 \pm 139$ \\
Salmo spp.a/ & 6 & $83 \pm 55$ \\
\hline
\end{tabular}

a) Species composition: $W C T=67 \%, \quad \mathrm{HYB}=33 \%$ 


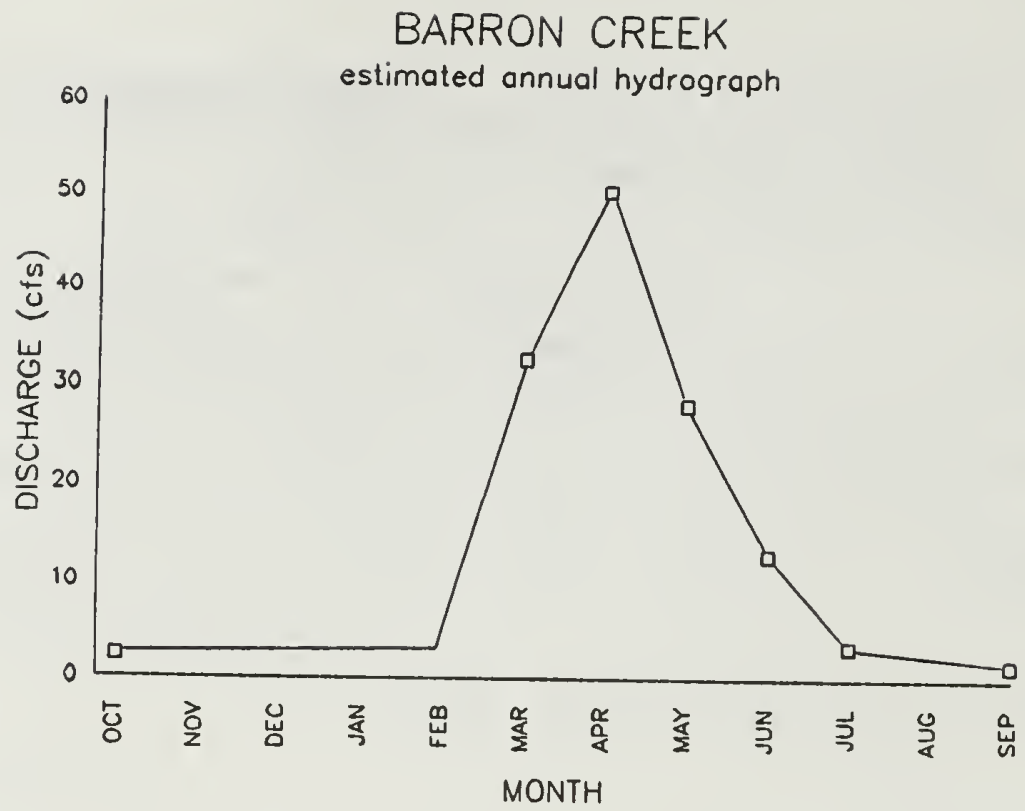

Figure 5. An estimated hydrograph for Barron Creek based on a comparison of 21 concurrent flow measurements made at the Tobacco River USGS stage-discharge gauging station, and miscellaneous measurements.

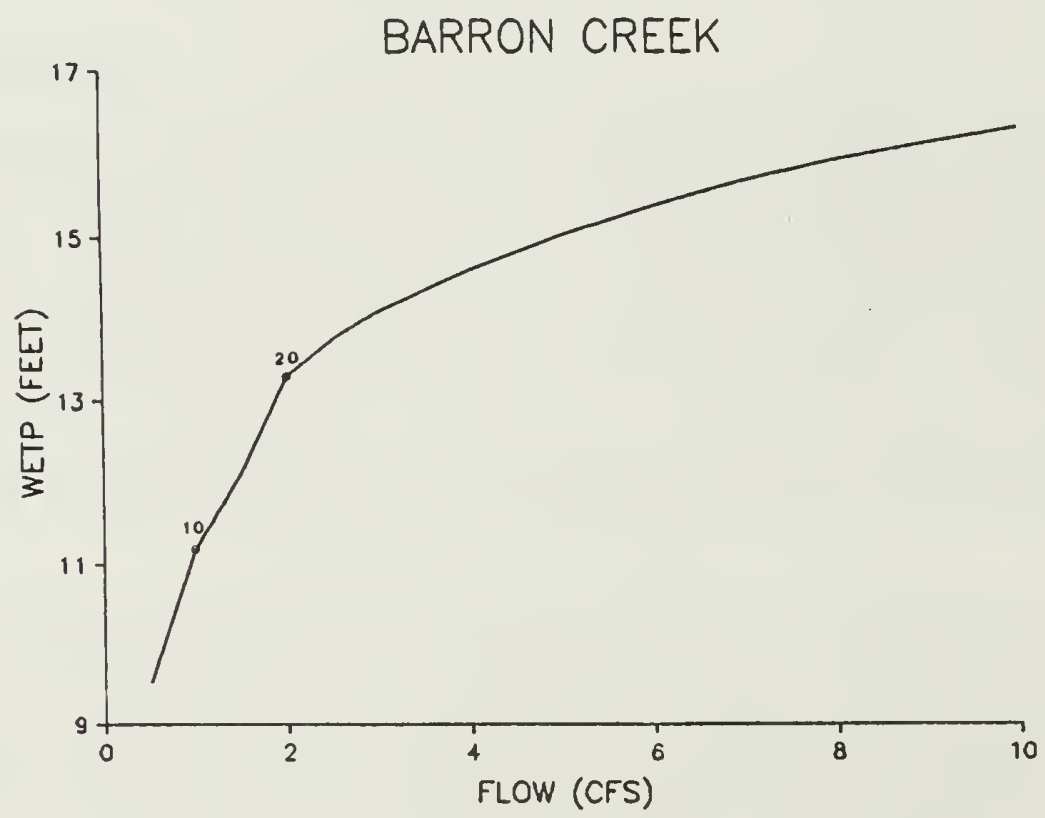

Figure 6. The wetted perimeter-discharge relationship for five riffle transects on Barron Creek 1985-1986. 
Table 3. Average depth at five riffle transects on Barron Creek at selected flows of interest.

\begin{tabular}{|c|c|c|c|c|c|}
\hline \multirow{2}{*}{$\begin{array}{l}\text { Flow } \\
\text { (cfs) }\end{array}$} & \multicolumn{5}{|c|}{ Average depth (ft) } \\
\hline & $\mathrm{CS1}$ & CS2 & $\operatorname{cs} 3$ & CS4 & CS5 \\
\hline 1.0 & .17 & .37 & .16 & .10 & .15 \\
\hline 2.0 & .29 & .56 & .28 & .23 & .23 \\
\hline 12.5 & .60 & .94 & .60 & .52 & .71 \\
\hline
\end{tabular}




\section{Big Creek}

\section{Description}

Stream reach: Big Creek from its confluence with the western shore of Libby Reservoir (T35N, R24W, Sec. 3) upstream to the junction of the north and south forks of Big Creek (T35N, R30W, Sec. 28) (Figure 7).

Stream Length: $11.7 \mathrm{~km}$. Total drainage area: $360.1 \mathrm{~km}^{2}$. Gradient, mouth to north and south forks: $19.8 \mathrm{~m}$ per $\mathrm{km}$.

\section{Source and Land Use}

Big Creek originates on the east slopes of the Purcell Mountains in two major forks which join from the north and south, then flows east for $11.7 \mathrm{~km}$ to the western shore of Libby Reservoir. The entire Big Creek drainage is located in the Kootenai National Forest. Timber production is the primary land use in the drainage.

\section{Flows}

The U.S. Geological Survey, Water Resources Division maintained a water-stage recorder in T35N, R29W, Sec. 33 from October 1972 through September 1981 (USGS 1973-1982). Daily discharge measurements during this period are summarized in an annual hydrograph (Figure 8). Mean annual discharge is $119 \mathrm{cfs}$. Infrequent measurements were also made by personnel of the Kootenai National Forest.

\section{Potential Environmental Problems}

Big Creek has been targeted for small scale hydroelectric development. Although applications for power resource construction were later withdrawn, interest in future development is anticipated as surplus power in the region decreases and costbenefit ratios improve, making hydropower facilities once again economically attractive.

Increased sediment loads and higher peak flows resulting from timber production could reduce recruitment to the reservoir from the Big Creek drainage. 


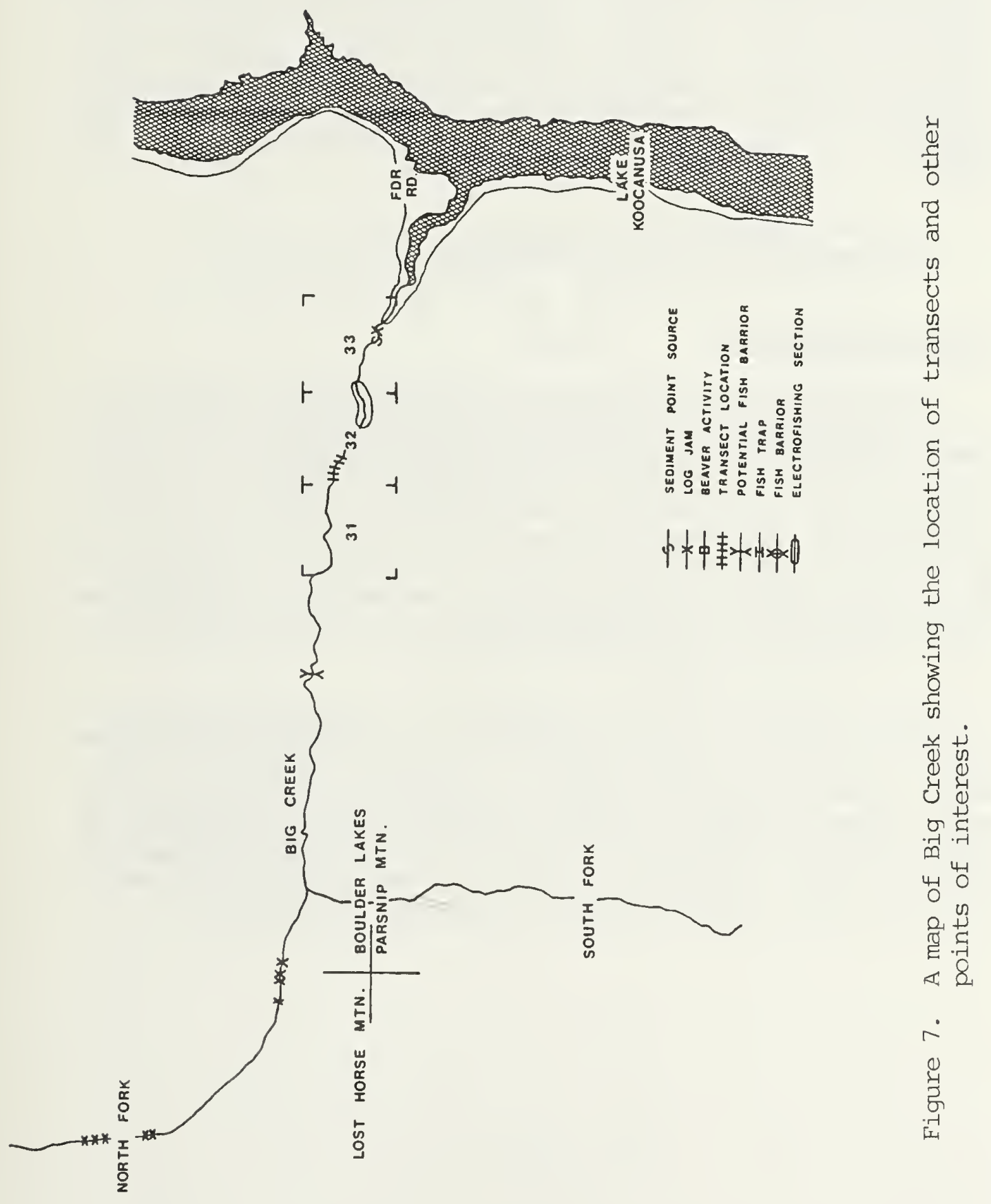


Resident and Pre-emigrant Fish

A mark-recapture population estimate was made on a representative $120-\mathrm{m}$ section chosen for its location between two natural constrictions in the stream. Results revealed that game fish in Big Creek include westslope cutthroat trout, rainbow trout, rainbow-cutthroat hybrids, bull trout, eastern brook trout, mountain whitefish, and burbot (Table 4). Based on a lengthfrequency histogram (Appendix A2) and a capture efficiency curve (Appendix A3), the Salmo spp. population is best described in two groups:

Fish $>85 \mathrm{~mm}$ through $140 \mathrm{~mm}$ TL

and Fish $>140 \mathrm{~mm}$ through $255 \mathrm{~mm}$ TL.

\section{FLOW RECOMMENDATIONS}

Five permanent transects were established on riffle areas located approximately $2.5 \mathrm{~km}$ upstream of the Forest Development Road (T35N, R29W, Sec. 32, NE-1/4). The WETP program was calibrated to stage and discharge measurements at flows of $36.3,42.7$ and $311.0 \mathrm{cfs}$. The lower and upper inflection points in a plot of the wetted perimeter-discharge relationship occur at flows of 19 and $32.5 \mathrm{cfs}$, respectively (Figure 9). Based on an evaluation of the existing fishery, results of the wetted perimeter analysis and water availability, a discharge of $19 \mathrm{cfs}$ is recommended for the low flow period from July 16 through March 31.

An average depth of $0.5 \mathrm{ft}$, required for successful passage of spawning migrants, is not reached in all transects until flows equal or exceed $37.5 \mathrm{cfs}$ (Table 5). A flow of $37.5 \mathrm{cfs}$ is therefore recommended for the period from April 1 through July 15 to ensure migrant passage and protect spawning redds from dewatering. Recommendations have been set for half-month intervals based on historical water availability (Table 6). Recommended flows amount to 45.6 percent of the mean annual discharge on record. 


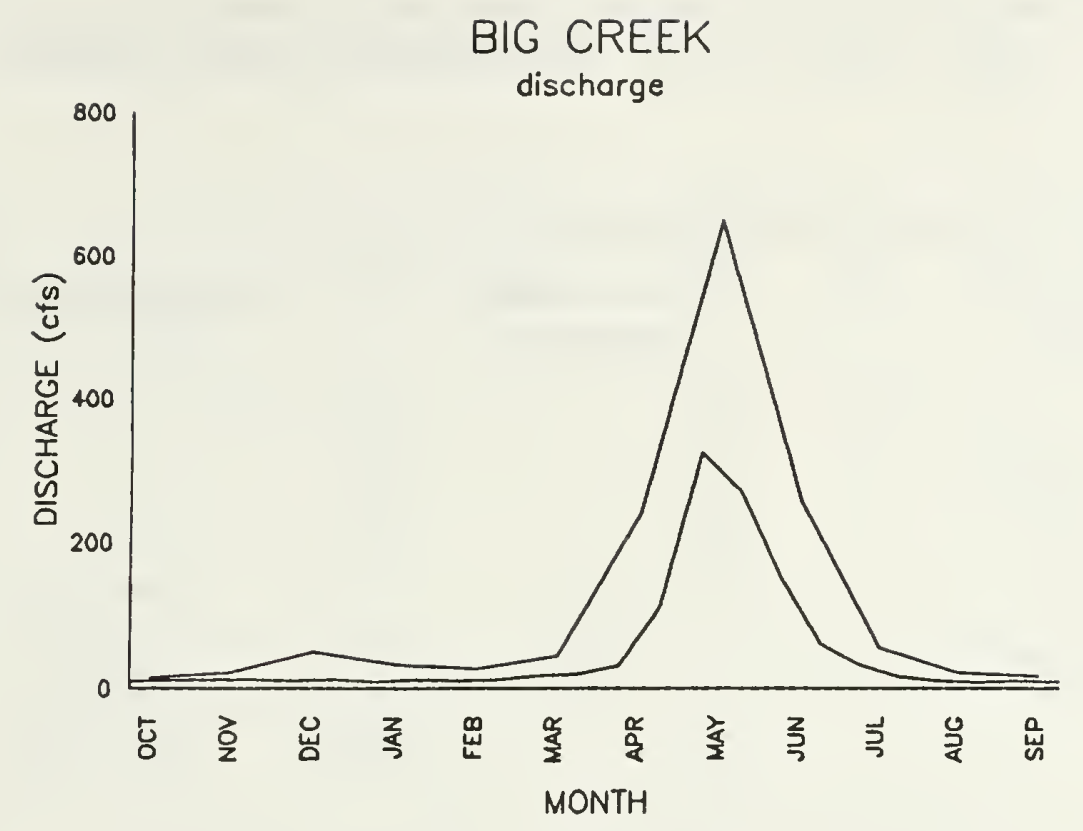

Figure 8. Mean monthly flows (top line) and eightieth percentile exceedence flows (bottom line) based on 10 years of daily stage records for Big Creek (USGS).

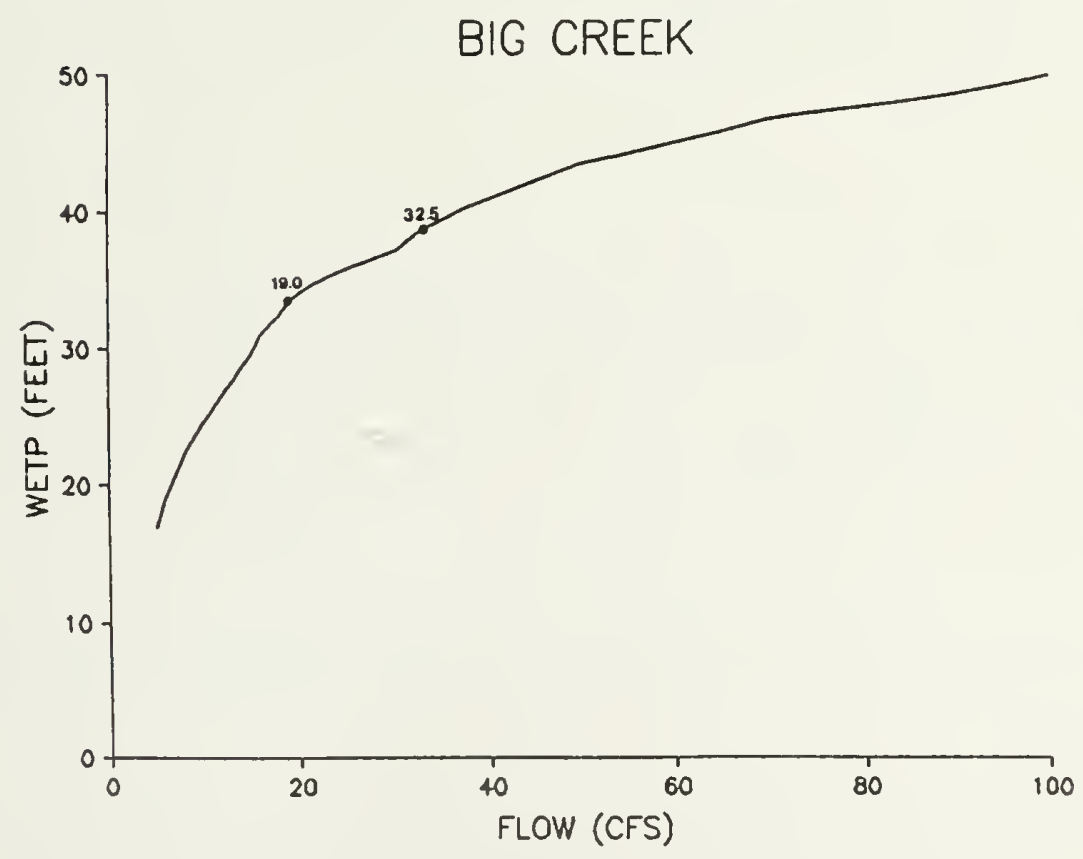

Figure 9. The wetted perimeter-discharge relationship for five riffle transects on Big Creek 1985-1986. 
Table 4. Results of mark-recapture estimate conducted on Big Creek (T35N, R29W, Sec. 32) during August 1986. Discharge 37.5 cfs.

Length

Categories
Total Number

Captured
Estimated mumber per $1 \mathrm{~km}$

Salmo spp. a/

$>85-140 \mathrm{~mm}$

92

$594 \pm 291$

>140-255 mm

54

$225 \pm 97$

TOTAL

$819 \pm 388$

a) Species composition: $\mathrm{RB}=63.4 \%, \mathrm{WCT}=16.8 \%, \mathrm{HYB}=19.8 \%$ 
Table 5. Average depth in five riffle transects on Big Creek at selected flows of interest.

\begin{tabular}{|c|c|c|c|c|c|}
\hline \multirow{2}{*}{$\begin{array}{l}\text { Flow } \\
\text { (cfs) }\end{array}$} & \multicolumn{5}{|c|}{ Average depth (ft) } \\
\hline & $\mathrm{CSI}$ & $\mathrm{CS} 2$ & $\operatorname{cs} 3$ & CS4 & $\operatorname{CS} 5$ \\
\hline 19.0 & .33 & .50 & .55 & .76 & .49 \\
\hline 32.5 & .47 & .72 & .70 & .82 & .64 \\
\hline 37.5 & .50 & .77 & .74 & .88 & .66 \\
\hline
\end{tabular}


Table 6. Recommended minimum flows for Big Creek and historical water availability records based on ten years of daily records (USGS).

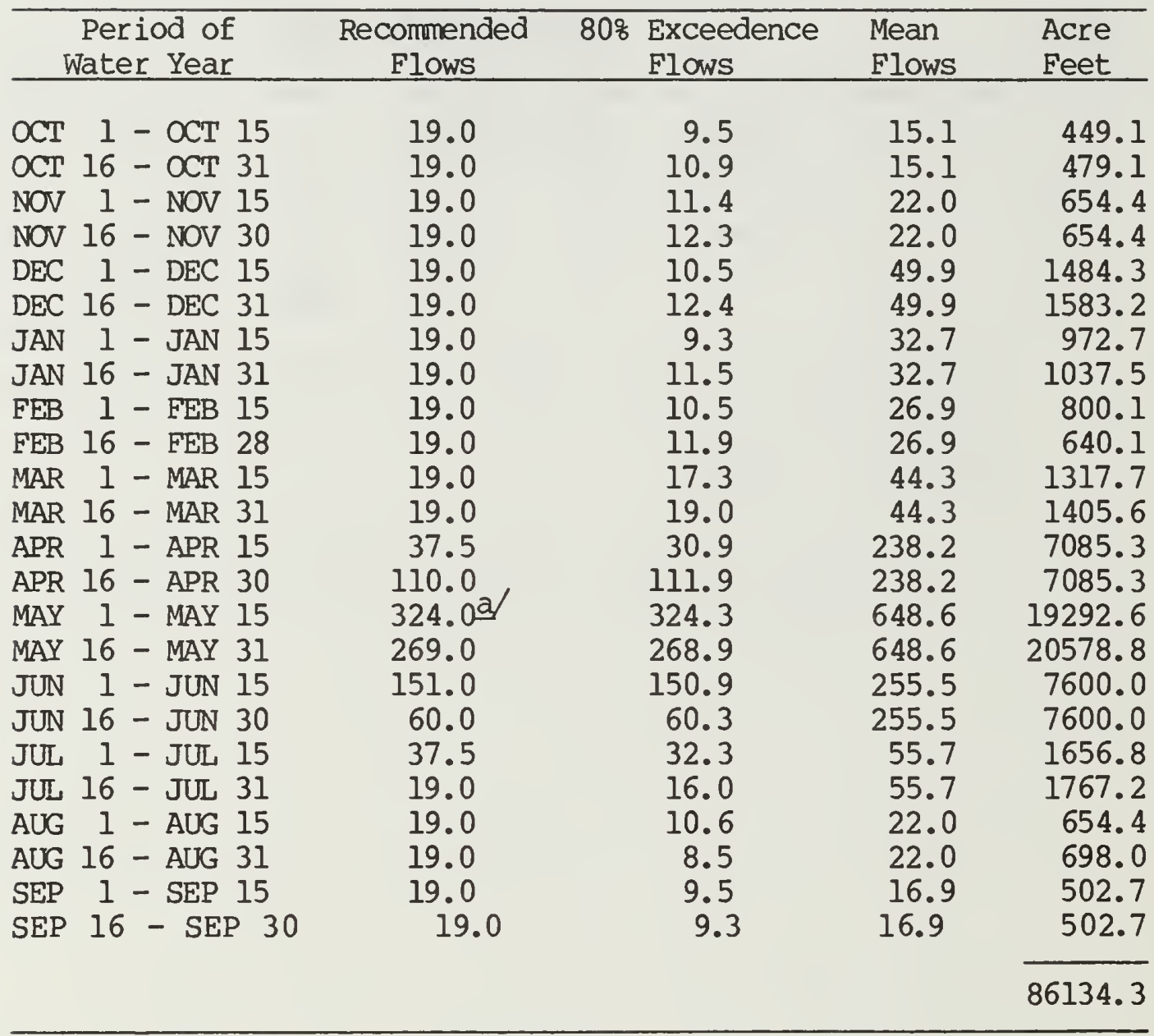

a) A dominant discharge flow (the approximated bank full flow presently undefined) should be maintained for 24 hours during this period. 


\section{Bristow Creek}

\section{Description}

Stream reach: Bristow Creek from its confluence with the western shore of Libby Reservoir (T32N, R29W, Sec. 5) to the source (T32N, R30W, Sec. 2) (Figure 10).

Stream length: $11.6 \mathrm{~km}$. Total drainage area: $60.3 \mathrm{~km}^{2}$. Gradient: $43.8 \mathrm{~m}$ per $\mathrm{km}$.

\section{Source and Land Use}

Bristow Creek originates at the north and south forks on the eastern slope of the Purcell Mountains and flows east for $11.6 \mathrm{~km}$ into the western shore of Libby Reservoir. Except for a small strip of land owned by Champion International located in two sections of the Bristow Creek, the entire drainage is in the Kootenai National Forest. Timber production is the primary land use in the drainage.

\section{Flows}

Little flow information has been collected on Bristow Creek except for infrequent measurements taken by personnel of the Kootenai National Forest and the U.S. Geological Survey 1974-1975. Miscellaneous measurements were compiled to construct an estimated hydrograph for water availability (Figure 11). Estimated mean annual discharge is 18.2 cfs.

\section{Potential Environmental Problems}

Timber harvest in the Bristow Creek drainage has resulted in increased peak flows, causing instability in some portions of the creek. The Kootenai National Forest has selectively cut high-risk trees in the riparian zone to reduce sediment loading associated with root wad dislocation and to retain stream bank cover and stability. Barrier removal has also been conducted to maintain access for migrant spawners.

Planned timber sales in the drainage will probably increase sediment and decrease stream stability and could potentially limit fish production in the stream. 


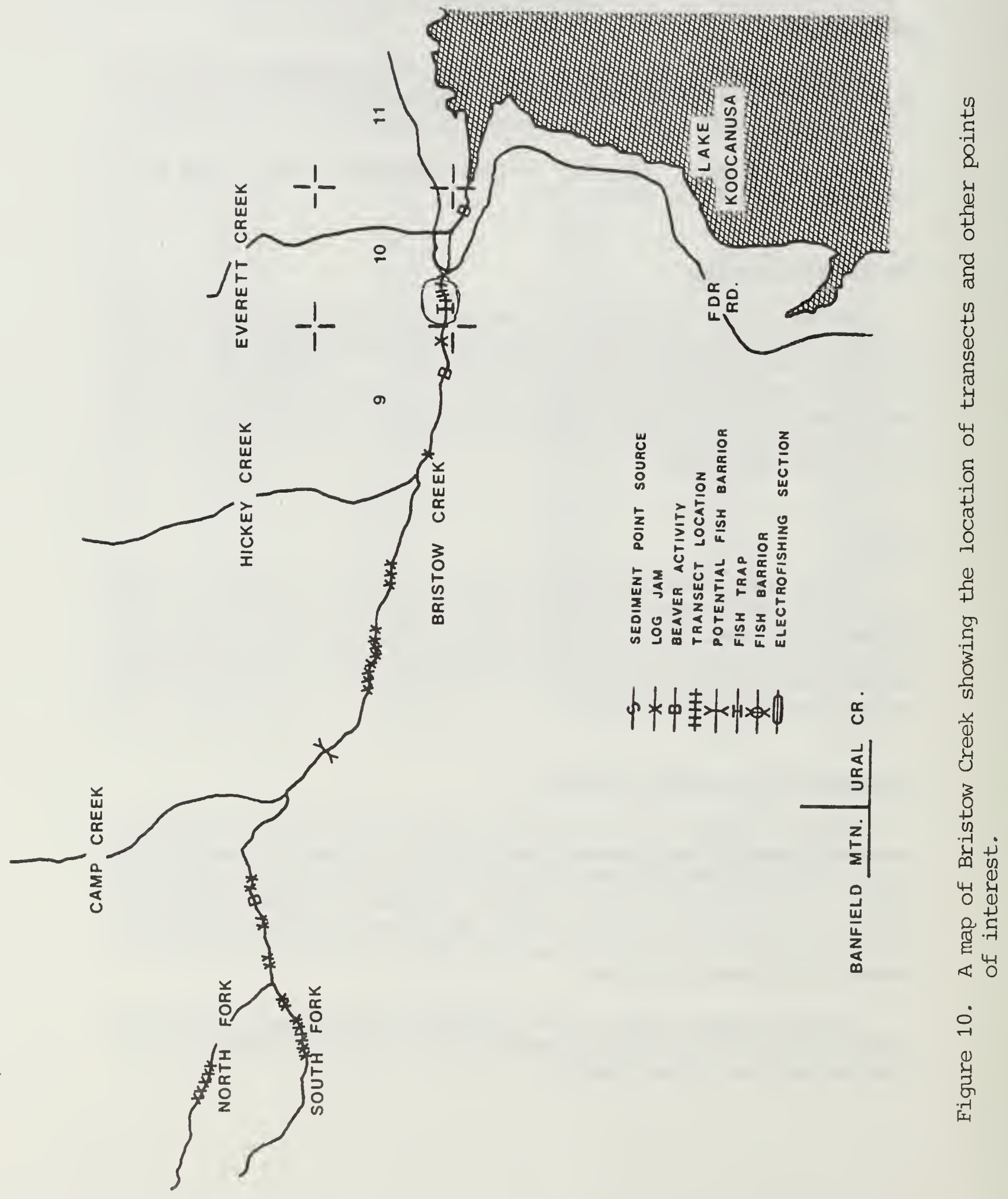




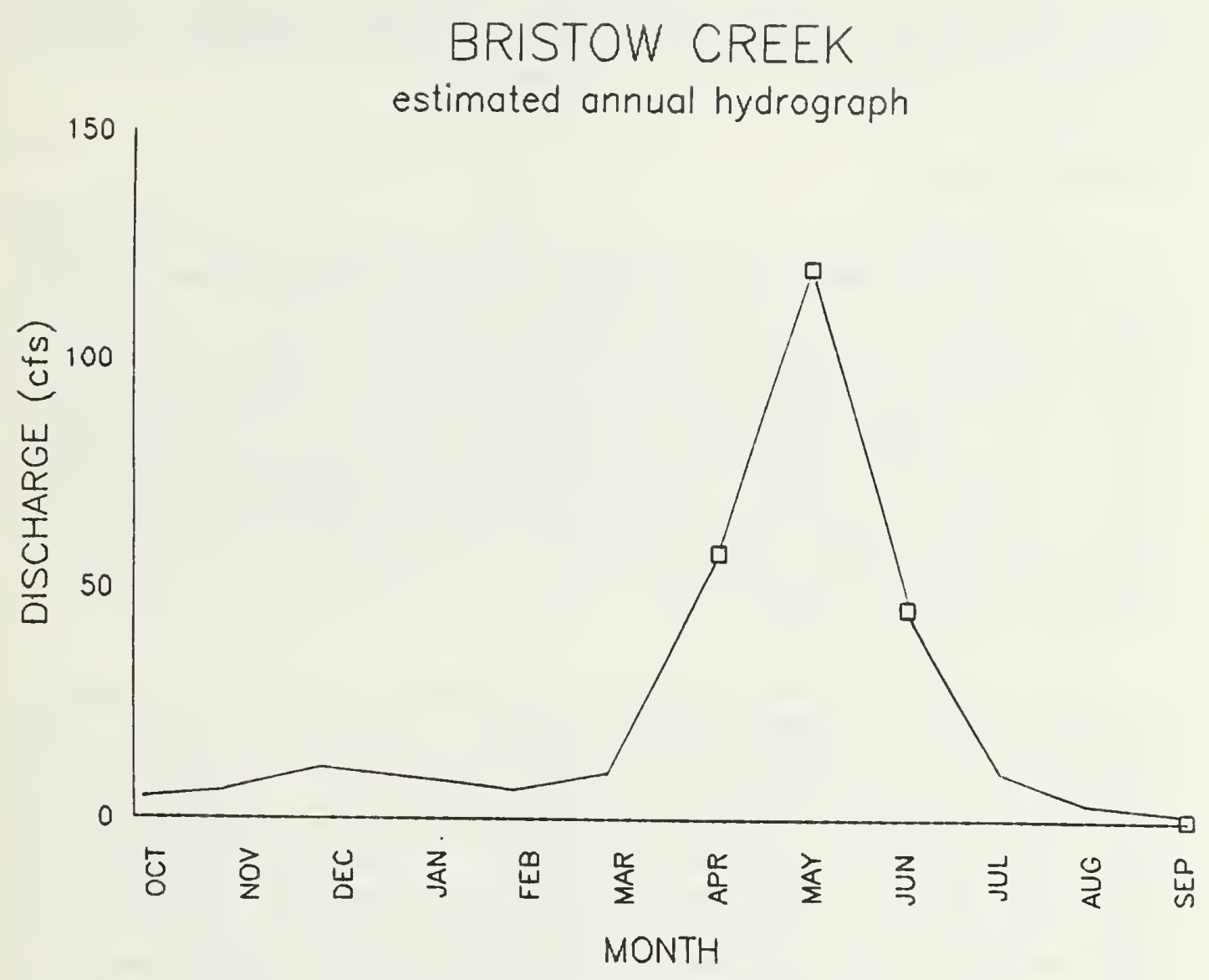

Figure 11. An estimated annual hydrograph for Bristow Creek based on a comparison of six concurrent flow measurements made at the Tobacco River USGS stagedischarge gauging station, and 39 miscellaneous discharge measurements. 


\section{Resident and Pre-emigrant Fish}

Results of a two-pass population estimate on a 112-m blocknetted section of stream disclosed that game fish in Bristow Creek were predominantly Salmo spp. (Appendix A4) and relatively smaller numbers of eastern brook trout (Table 7).

\section{Migrant Trapping}

A bi-directional trap structure was installed approximately $1.5 \mathrm{~km}$ above the mouth in Bristow Creek (T32N, R29W, Sec. 10) to capture migrants traveling both up and downstream. Traps were monitored simultaneously during the period from April 7, 1986 through August 1, 1986. The first capture took place on May 12, 1986. The number of upstream migrants captured in Bristow Creek totaled 161 Salmo spp., whereas 136 spent migrants were captured while exiting the creek. The maximum likelihood estimate of the total migrant population, calculated using Schnable's Multiple Census Formula (Ricker 1975), amounted to 285 fish, with a range of 224-336 ( $p \geq 0.95$, Poisson). Species composition was $R B=9.58$, WCT $=66.9 \%$ and $\mathrm{HYB}=23.68$.

The length-frequency histogram upstream for migrants nearly mirrors that for downstream migrants, indicating that the assumption of a closed population above the double trap structure was not violated (Figure 12). Mortality due to fishing was assumed to be equal among marked and unmarked fish; however, no fish tags have as yet been returned. At no time during the spawning run were both the upstream trap leads and downstream leads breached simultaneously. There is however a possibility that some fish may have escaped being trapped by leaping over or passing under the leads; bias was considered to be negligible since both marked and unmarked fish presumably have equal chance of escape.

The timing of the spawning run was well defined and shortlived, beginning on May 12, 1986 and ending on June 29, 1986. The onset of upstream migration corresponds with declining discharge and rising water temperatures (Figure 13). The length of time marked individuals remained at large in Bristow Creek after passing the trap structure averaged 19 days with a range of 8 to 34 days at large. 
Table 7. The results of a two-pass population assessment conducted in Bristow Creek (T32N, R29W, Sec. 10) during July 1985. Discharge approximately $6.6 \mathrm{cfs}$.

Total Number

Captured

Salmo spp. a/

153

Estimated Number Fish $\geq 75 \mathrm{~mm}$ per $\mathrm{km}$

eastern brook trout
5

$1,179+143$

b/

a) Species composition: $\mathrm{RB}=4 \%$, $\mathrm{WCT}=50 \%$, $\mathrm{HYB}=46 \%$

b/ $\hat{p}=0.33$ insufficient for estimate 


\section{BRISTOW CREEK}
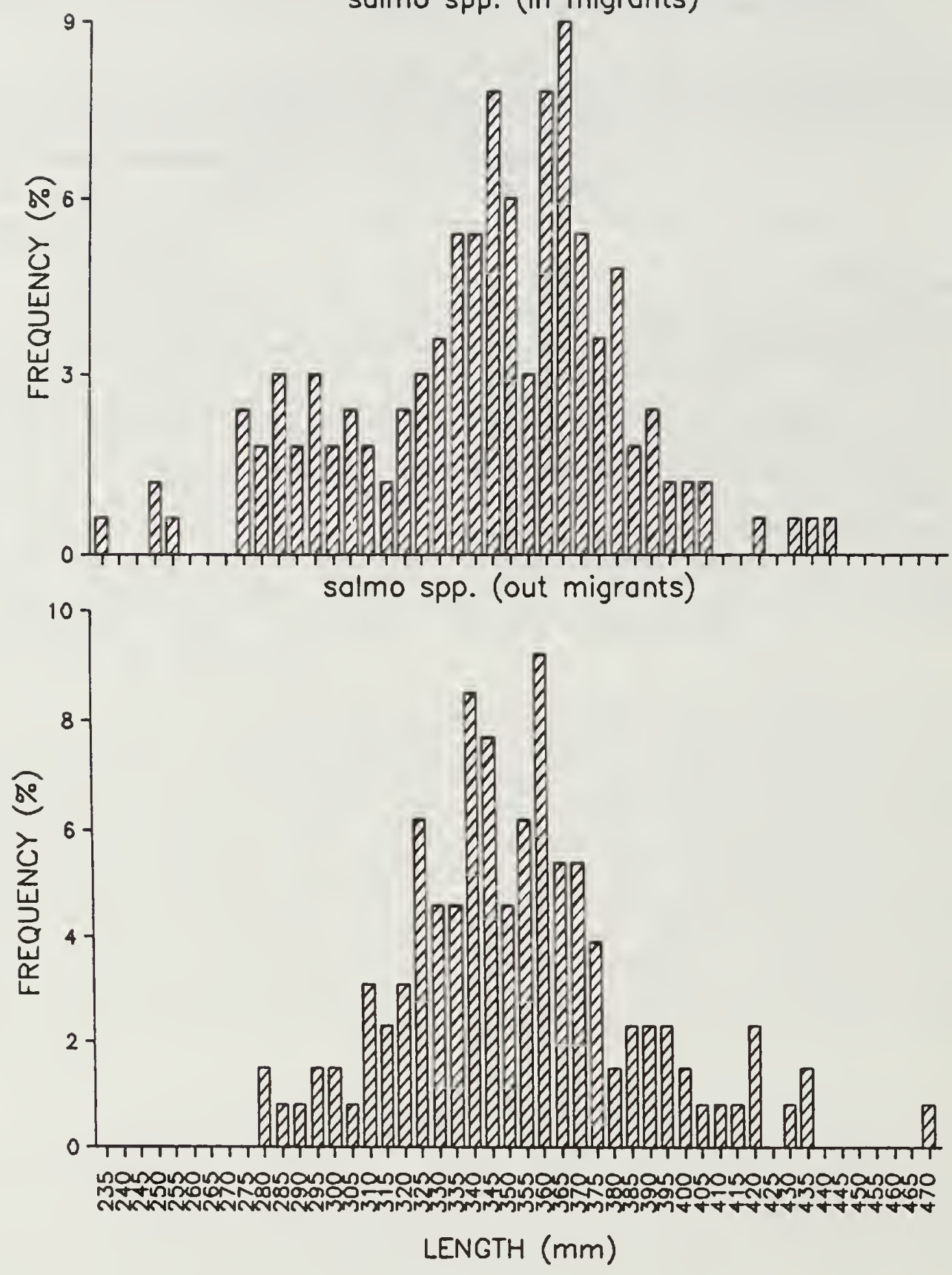

Figure 12. Length-frequency histograms of Salmo spp. captured while migrating into (top) and out of Bristow Creek (bottom) during the spring spawning run 1986. 


\section{BRISTOW MIGRANT TRAPS \\ cotch over time}

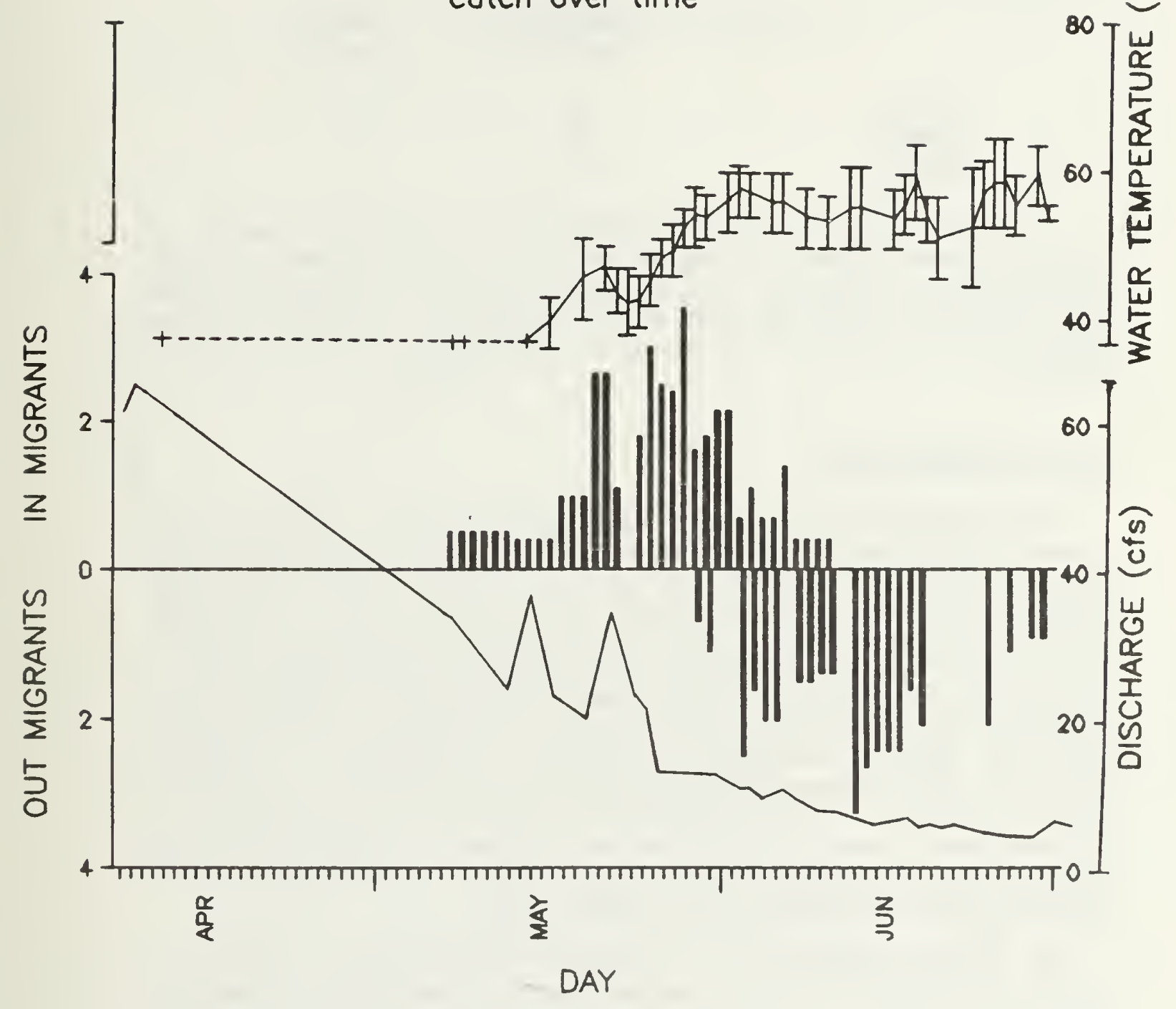

Finure 13. Catch direction and distribution over time 0 minratinn Salmo son. cantured at the Bristow Creek trapoind stmucture durind sorind 10?5 (vortical bars, middle), and associated wator tomoratures (rannc and mean, top) and stream discharge (bottom). (Note: logarithmic scale) 
Redds observed by field personnel were placed into the following categories:

$\begin{array}{cc}\text { Above } & \text { Below } \\ \text { trap site } & \text { trap site }\end{array}$

$\begin{array}{lll}\text { Definite } & 44 & 1 \\ \text { Probable } & 39 & 3 \\ \text { Possible } & 19 & 3\end{array}$

A comparison of estimated spawners (utilizing that portion of Bristow Creek above the trap structure) to the number of redds classified as definite and probable produced an estimate of approximately 3 fish per redd with a range of 2.7 to 4.0 . The sex ratio of individual fish captured in the trap was 1:2 (males to females).

\section{FLOW RECOMMENDATIONS}

Five permanent transects were established on riffle areas located approximately $1.5 \mathrm{~km}$ upstream from the mouth (T32N, R29W, Sec. 10, SW-1/4). The WETP program was calibrated to stage and discharge measurements at flows of $0.7,8.5,11.4,28.1,37.2$, $47.9,50.4$, and $64.7 \mathrm{cfs}$. The lower and upper inflection points in a plot of the wetted perimeter-discharge relationship occur at flows of 5 and $12 \mathrm{cfs}$, respectively (Figure 14). Based on an evaluation of the existing fishery, results of the wetted perimeter analysis and estimated water availability, a discharge of $12 \mathrm{cfs}$ is recommended for the low flow period from July 16 through March 31. Stream discharge was observed to flow subgravel in some areas causing visible stream discharge to fall below the recommended flow, indicating that the fishery environment is below optimum during portions of some water years.

An average depth of $0.5 \mathrm{ft}$ required for successful passage of spawning migrants is not reached until flows equal or exceed $13 \mathrm{cfs}$ (Table 8). A minimum passage flow of $13 \mathrm{cfs}$ is therefore recommended for the period from April 1 through July 15 to ensure migrant passage and protect redds from dewatering. 


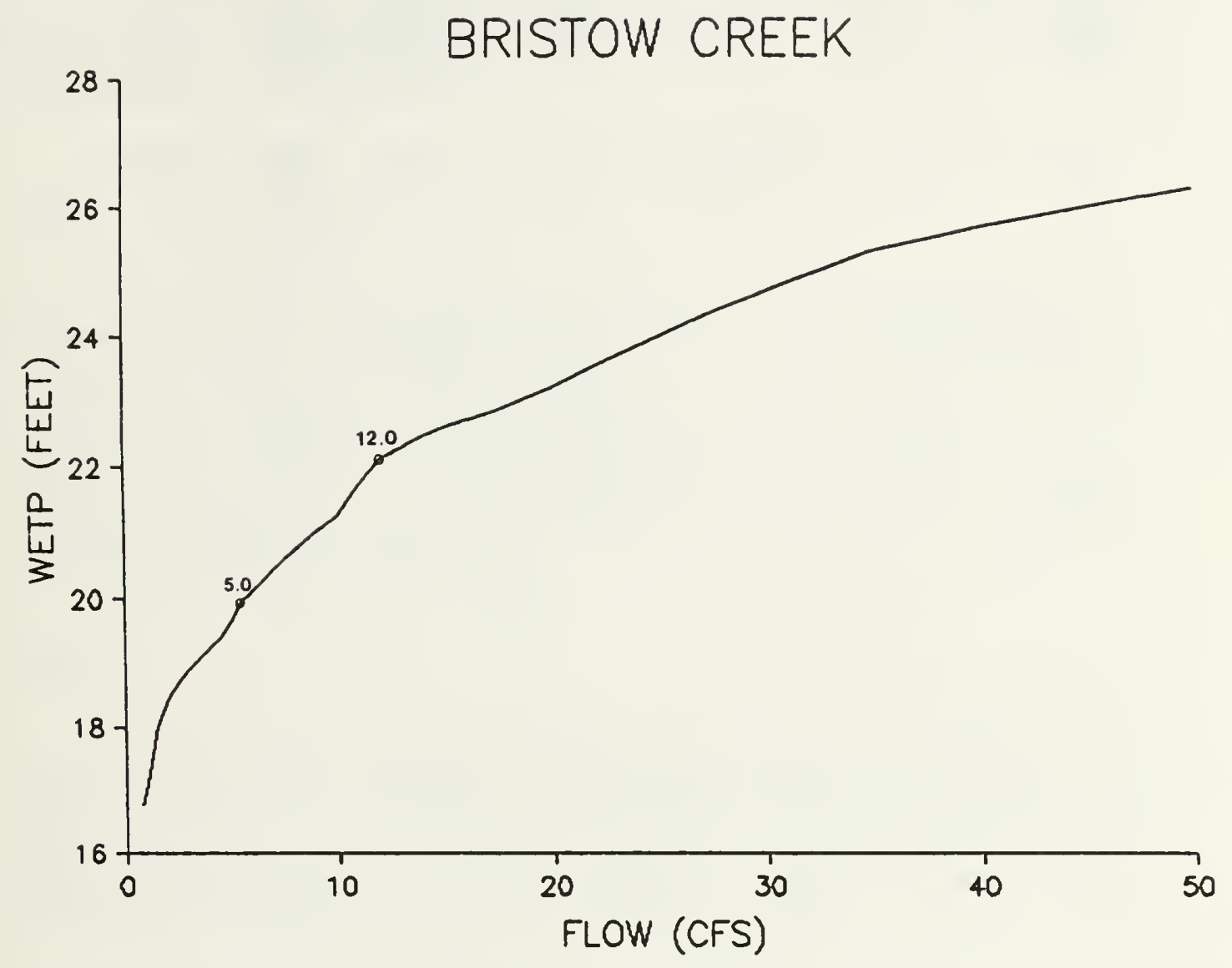

Figure 14. The wetted perimeter-discharge relationship for five riffle transects on Bristow Creek 1985-1986. 
Table 8. Average depth at five riffle cross-sections on Bristow Creek at selected flows of interest.

\begin{tabular}{lllllll}
\hline \multirow{2}{*}{$\begin{array}{l}\text { Flow } \\
\text { (cfs) }\end{array}$} & \multicolumn{6}{c}{ Average depth } \\
\cline { 2 - 6 } 5 & CS1 & CS2 & CS3 & CS4 & CS5 \\
\hline 13 & .65 & .49 & 1.18 & .36 & .73 \\
\hline
\end{tabular}




\section{Deep Creek}

\section{Description}

Stream reach : Deep Creek from its confluence with Fortine Creek (T35N, R26W, Sec. 25) to the spring creeks (T35N, R25W, Sec. 29, SE-1/4) and from the spring creeks to the source (T35N, R24W, Sec. 17) (Figure 15).

Stream length: $16.2 \mathrm{~km}$. Total drainage area: $55.4 \mathrm{~km}^{2}$. Gradient, mouth to the springs: $20.8 \mathrm{~m}$ per $\mathrm{km}$, springs to the source: $64.9 \mathrm{~m}$ per $\mathrm{km}$.

Deep Creek originates on the western slope of the Whitefish Range and flows west-southwest for $16.2 \mathrm{~km}$ to its confluence with Fortine Creek near Fortine, Montana. Portions of six sections within the Deep Creek drainage are privately owned. Of these sections, a segment of one belongs to Burlington Northern. The remainder of the watershed is in the Kootenai National Forest. Timber production is the primary land use in the drainage, although there is a considerable portion of arable land used for pasture and forage production.

\section{Flows}

A crest-stage gauge has been operated by the U.S. Geological Survey from 1959 to present. (T35N, R25W, Sec. 30, SW-1/4). The gauge measures annual maximum discharge. Infrequent data have also been collected by Montana Department of Fish, Wildlife and Parks. Miscellaneous data were compiled to construct an estimated hydrograph for water availability (Figure 16).

\section{Potential Environmental Problems}

Water appropriations listed for Deep Creek amount to $31.09 \mathrm{cfs}$ not including amounts allocated for livestock which are based on stock type and herd size (Index of Claims, State Water Rights, Helena, Montana). Estimated mean annual discharge is $16.7 \mathrm{cfs}$. If all water users exercise their water rights to the fullest extent, the stream will be dewatered during most of the water year. It is not known, however, what percentage of the existing appropriations are valid or presently in use.

Livestock access, unrestrained in pasture lands bordering the creek in the lower $3 \mathrm{~km}$ of Deep Creek, has accelerated bank erosion and sediment loading.

Saw mill waste and leachates are entering Deep Creek near its confluence with Fortine Creek. 


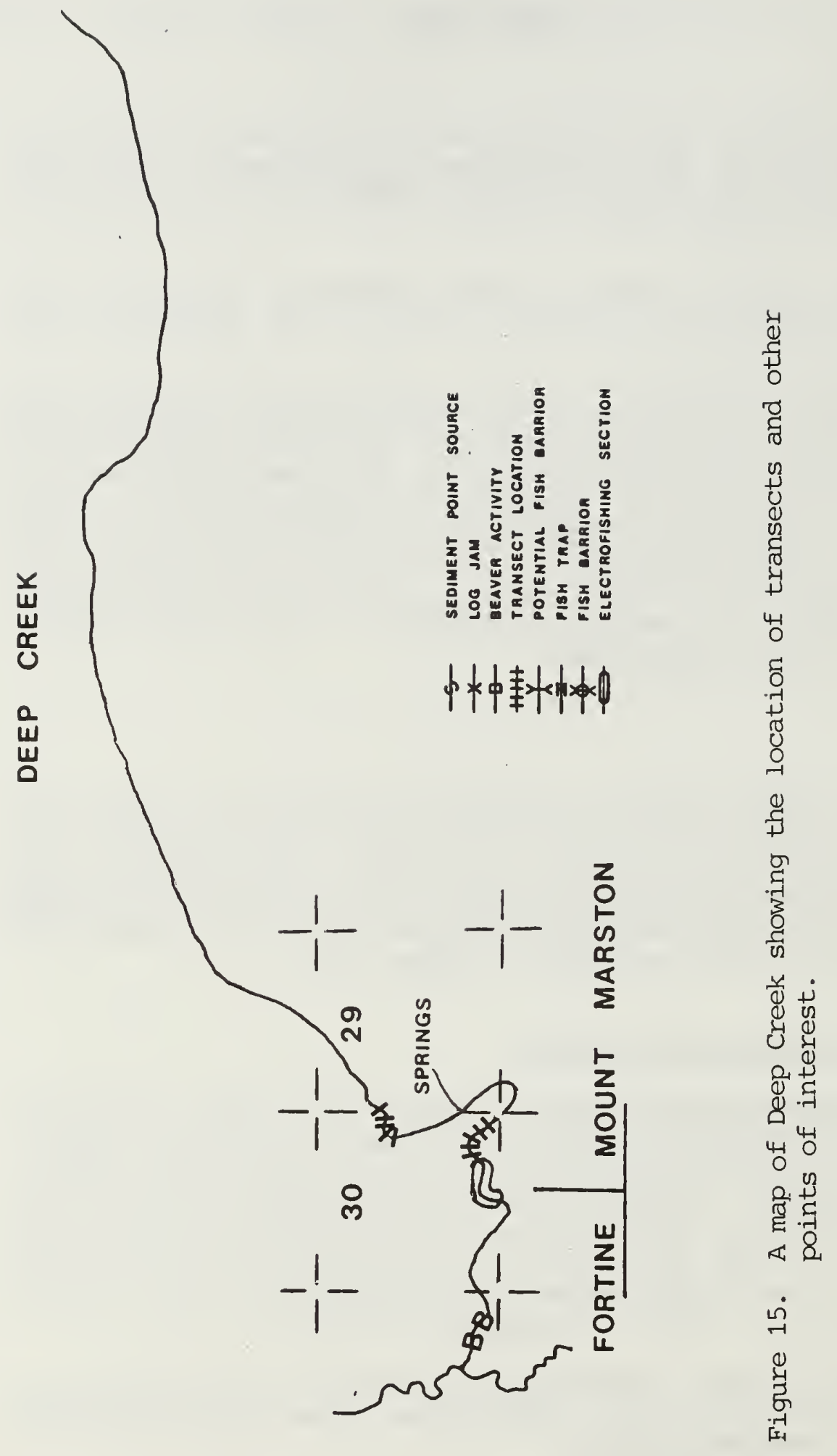




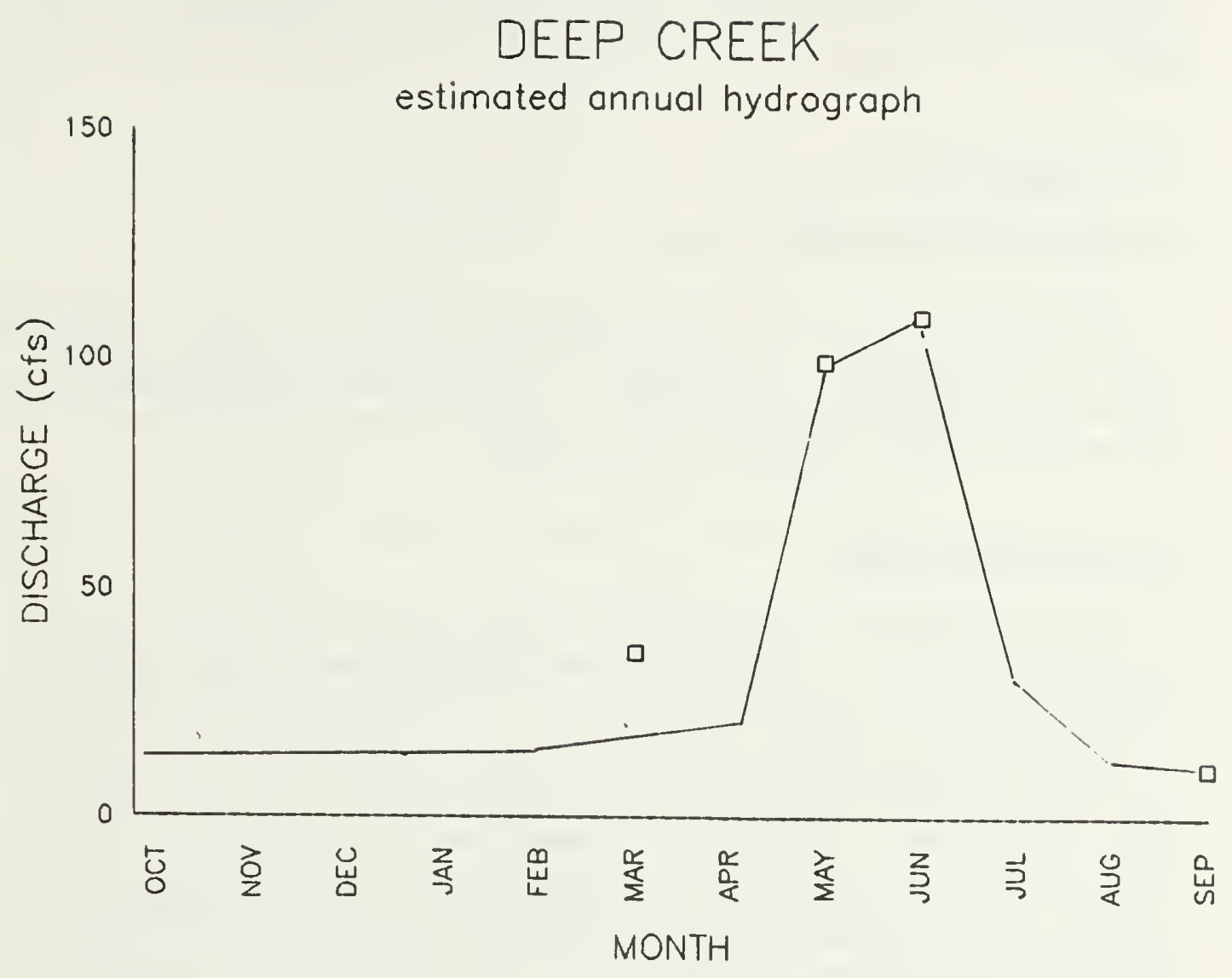

Figure 16. An estimated annual hydrograph for lower Deep Creek based on a comparison of 20 concurrent flow measurements made at the Tobacco River USGS stage-discharge gauging station; 24 years of USGS annual maximum discharge data, and miscellaneous flow measurements. 
Deep Creek has been targeted for microhydro development. Although the original application was later withdrawn, future development is anticipated when the region's power surplus declines and improved cost-benefit ratios make development of hydroelectric projects more attractive.

\section{FISH POPULATIONS}

\section{Resident and Pre-emigrant Fish}

Results of a two-pass population estimate on a 109.7-meter blocknetted section of stream disclosed that game fish in Deep Creek were predominantly Salmo spp. and relatively smaller numbers of eastern brook trout (Table 9). Length-frequency histograms show modal lengths (Appendix A5 and A6).

\section{FLOW RECOMMENDATIONS}

Five permanent transects were established on riffle areas located approximately $1 \mathrm{~km}$ upstream from the mouth (R35N, R25W, Sec. 30, SE-1/4). The WETP program was calibrated to stage and discharge measurements at flows of 17.6, 23.0, and 101.7 cfs. The lower and upper inflection points in a plot of the wetted perimeter-discharge relationship occur at flows of 3.0 and 8.0 cfs, respectively (Figure 17). Based on an evaluation of the existing fishery, results of the wetted perimeter analysis, and estimated water availability, a discharge of $8 \mathrm{cfs}$ is recommended for the low flow period from July 1 through March 31. This segment of Deep Creek is unique in that approximately 40 percent of the flow enters lower Deep Creek from a series of springs in section 29.

Five additional transects and a stage gauge were installed upstream of the entry point of the spring creeks (upper). The WETP program was calibrated at flows of $2.5,14.0$, and $64.0 \mathrm{cfs}$. Lower and upper inflection points occur at flows of 4.0 and 12.0 , respectively (Figure 18). A discharge of 4.0 is recommended for that portion of Deep Creek upstream of the spring streams located in the SWl/4, of the SWl/4, Sec. 29 during the low flow period from July 1 through March 3. Flows calculated from water stage measured during the period from May 16, 1986 through August 1986 ranged from 87.8 to $2.5 \mathrm{cfs}$ and averaged $16.0 \mathrm{cfs}$ (Figure 19).

An average depth of $0.5 \mathrm{ft}$ is met at all transects at a discharge of $30 \mathrm{cfs}$. A minimum fish passage flow of $30 \mathrm{cfs}$ is therefore recommended for the period of April 1 through June 30 to ensure successful passage of migrant spawners (Table 10). 
Table 9. The results of a two-pass population assessment conducted on Deep Creek (T35N, R25W, Sec. 30) during September 1985. Discharge 17.6 cfs.

Total Number

Captured

63

60
Estimated Number Fish $\geq 75 \mathrm{~mm}$ per $\mathrm{km}$
Salmo spp. a/

eastern brook trout
$611 \pm 155$

$301 \pm 32$

a) Species composition: $\mathrm{RB}=7.9 \%, \mathrm{WCT}=76.28, \mathrm{HYB}=15.9 \%$ 


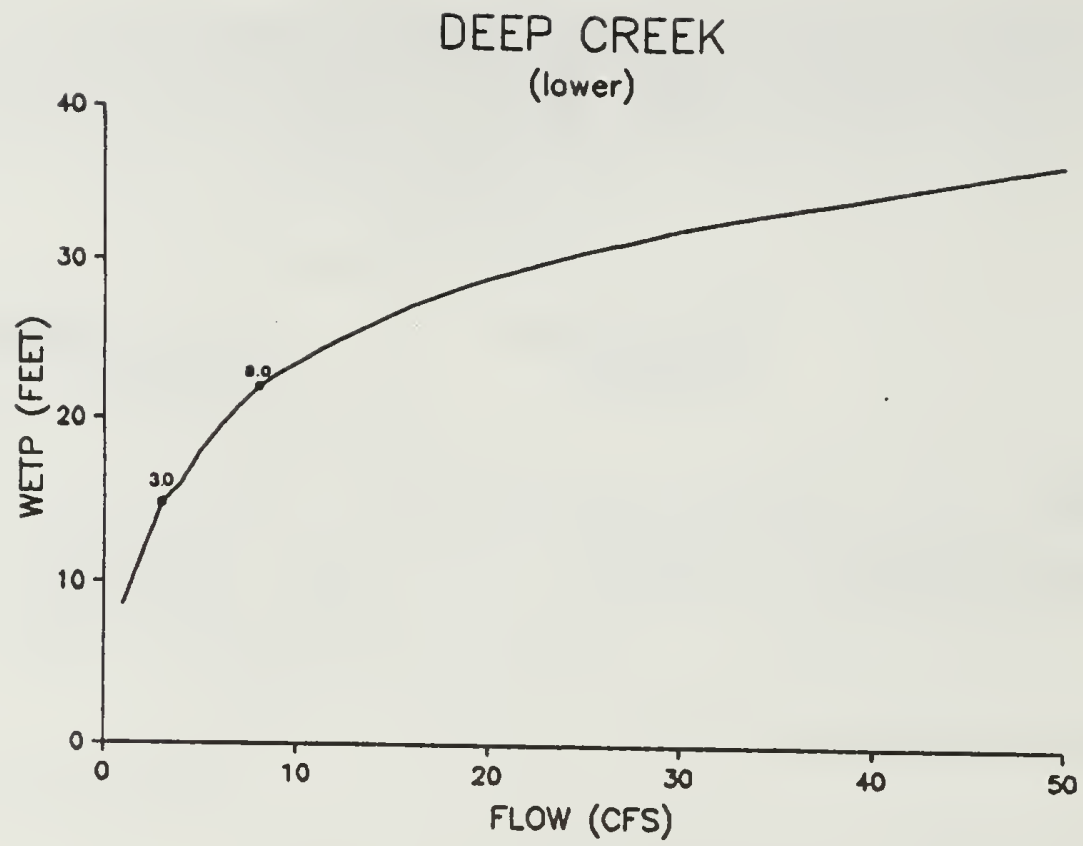

Figure 17. The wetted perimeter-discharge relationship for five riffle transects on lower Deep Creek 1985-1986.

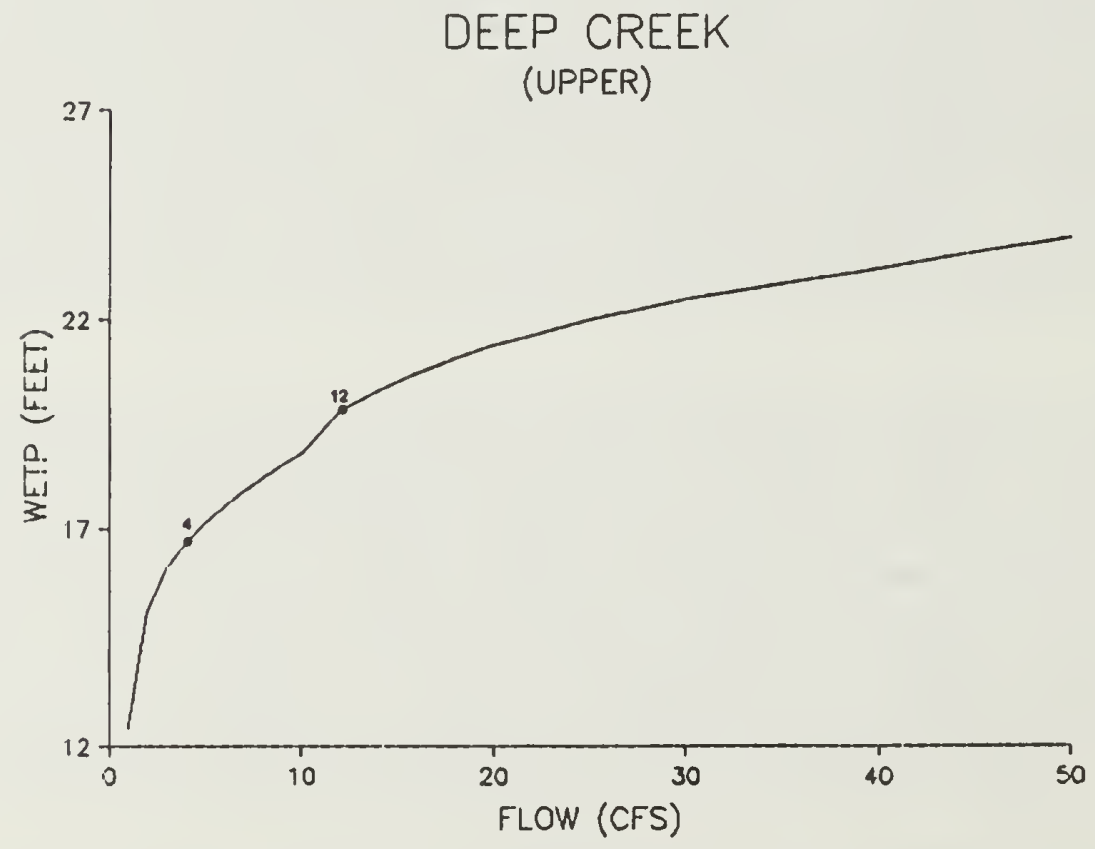

Figure 18. The wetted perimeter-discharge relationship for five riffle transects on upper Deep Creek 1986. 


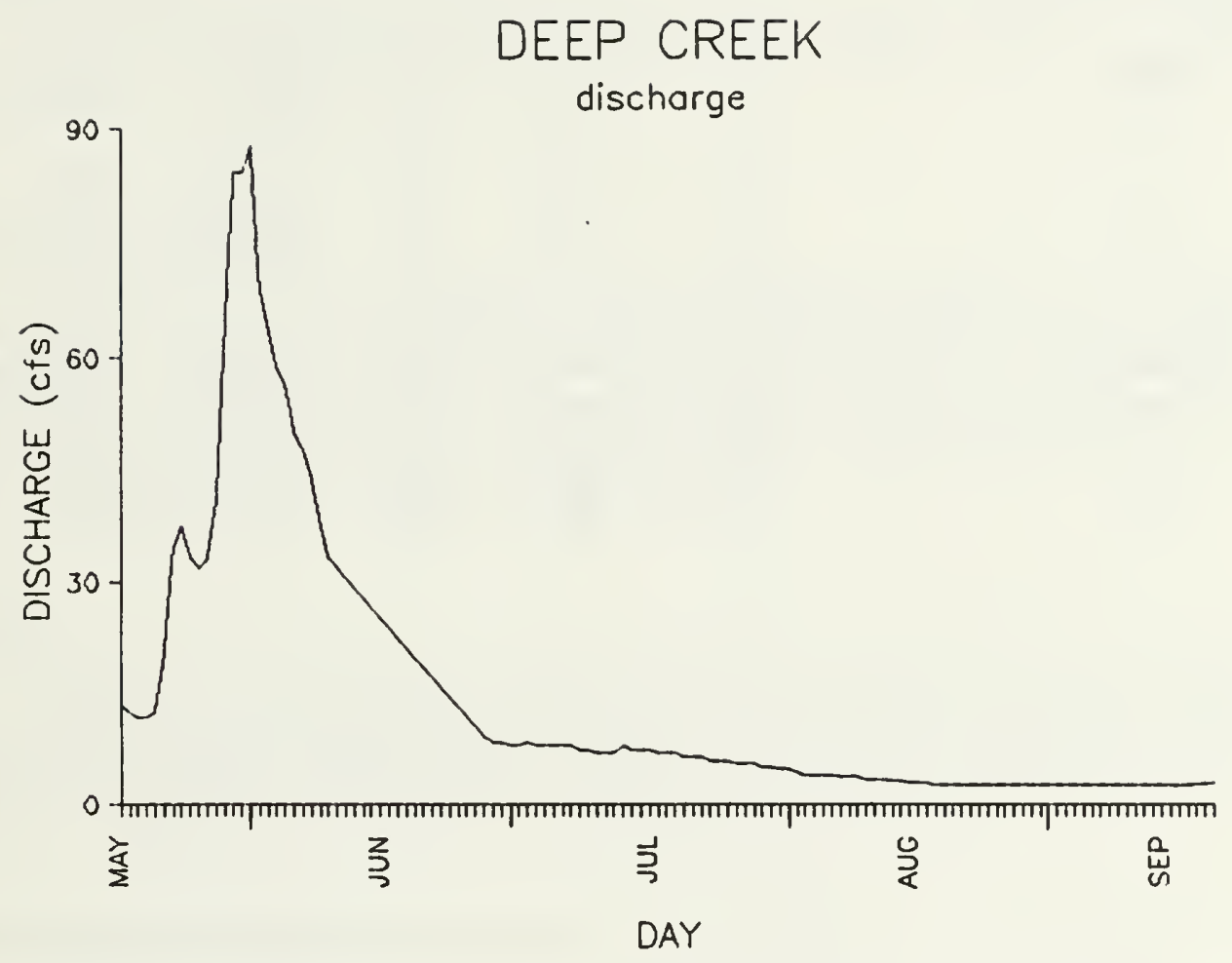

Figure 19. Stream discharge derived from stage gauge data for upper Deep Creek, May 16 - September 21, 1986. 
Table 10. The average depth for 10 riffle cross-sections in Deep Creek at selected flows of interest.

Discharge (cfs) Average depth (ft)

Transect group

\begin{tabular}{rrrrr}
\hline CS1 & CS2 & CS3 & CS4 & CS5 \\
& & & & \\
.17 & .18 & .22 & .13 & .25 \\
.34 & .26 & .31 & .20 & .38 \\
.71 & .54 & .59 & .61 & .73
\end{tabular}

Upper

$\begin{array}{lllll}\text { CS6 } & \text { CS7 } & \text { CS8 } & \text { CS9 } & \text { CS10 }\end{array}$

$\begin{array}{rrrrrr}4 & .24 & .24 & .21 & .99 & .73 \\ 12 & .33 & .40 & .39 & 1.24 & 1.02 \\ 30 & .54 & .63 & .61 & 1.48 & 1.32\end{array}$




\section{Fivemile Creek}

\section{Description}

Stream reach: Fivemile Creek from its confluence with the eastern shore of Libby Reservoir (T32N, R28W, Sec. 18) to the junction of the south fork of Fivemile Creek (T32N, R27W, Sec. 19) (Figure 20).

Stream Length: $8.4 \mathrm{~km}$. Total drainage area: $75 \mathrm{~km}^{2}$. Gradient: $9.7 \mathrm{~m}$ per $\mathrm{km}$.

\section{Source and Land Use}

Fivemile Creek originates on the western slopes of the Salish Mountains and flows west for approximately $11.6 \mathrm{~km}$ to Libby Reservoir. Other than one narrow strip of privately owned stream bottom and another owned by Champion International, the entire drainage is in the Kootenai National Forest. Timber production is the primary land use in the watershed.

\section{Flows}

Little flow data have been obtained on Fivemile Creek except for sporadic measurements taken by personnel of the Kootenai National Forest and Montana Department of Fish, Wildlife and Parks. Estimated mean annual discharge is 14.1 cfs.

\section{Potential Environmental Problems}

Timber harvesting could increase sediment loading and peak flows, causing channel instability and damage to fish habitat.

\section{FISH POPULATIONS}

\section{Resident and Pre-emigrant Fish}

A two-pass population assessment on a $112.8-\mathrm{m}$ blocknetted section of stream ascertained that most game $\mathrm{fish}$ in Fivemile Creek are Salmo spp. and relatively fewer numbers of eastern brook trout (Table 11). Length-frequency histograms present modal lengths (Appendix A7 and A8).

\section{FLOW RECOMMENDATIONS}

Five permanent transects were established on riffle areas located approximately $0.5 \mathrm{~km}$ upstream from the mouth (T32N, R28W, Sec. 17, NW-1/4. The WETP program was calibrated to stage and 


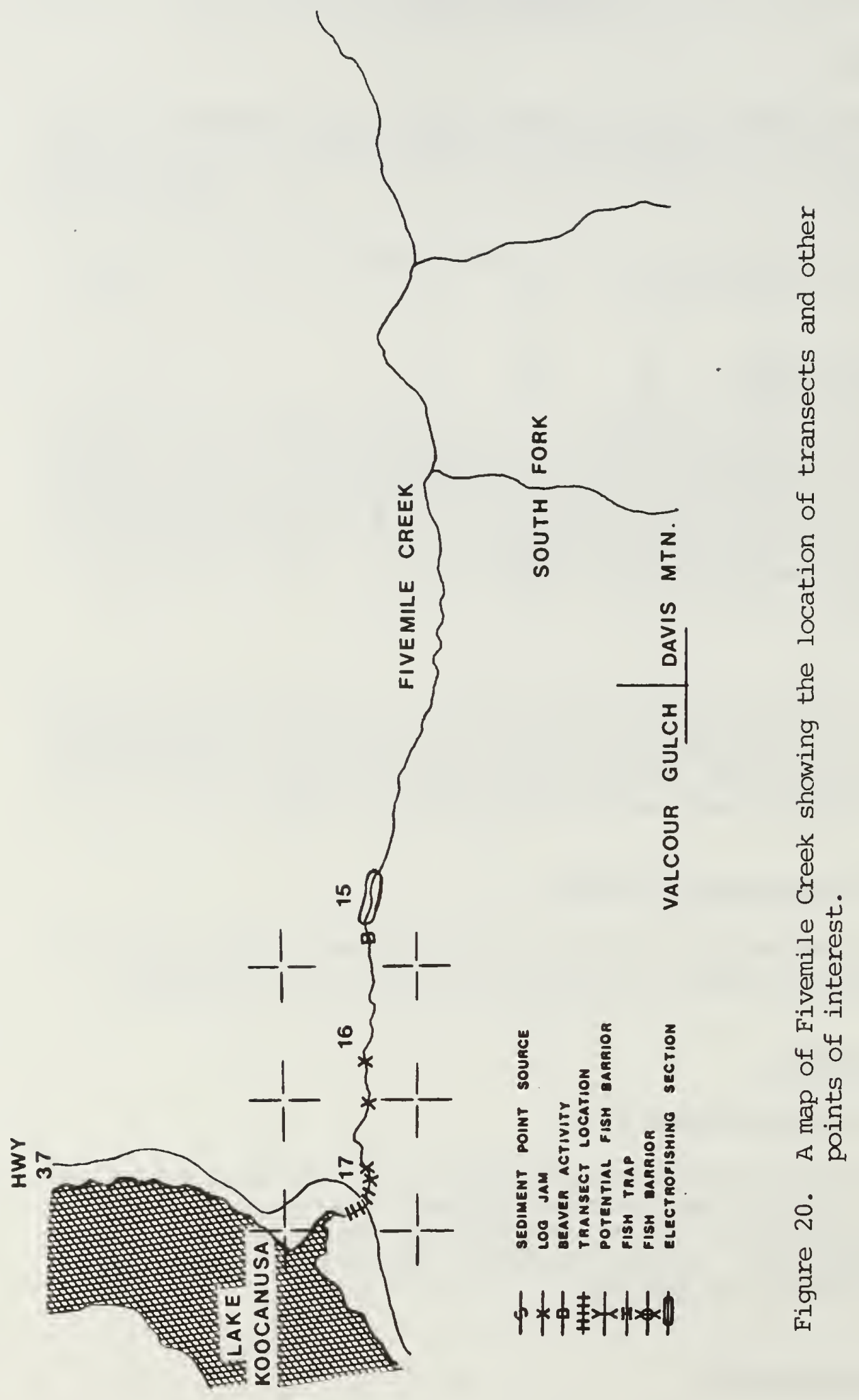


Table 11. The results of a two-pass population assessment conducted on Fivemile Creek (T32N, R28W, Sec. 24) during July 1985. No discharge on record.

Total Number

Captured
Estimated Number Fish $\geq 75 \mathrm{~mm}$ per $\mathrm{km}$
Salmo spp. a/

eastern brook trout
112

43
$465 \pm 128$

$243 \pm 160$

a) Species composition: $\mathrm{RB}=83.08, \mathrm{WCT}=10.7 \%$, $\mathrm{HYB}=6.3 \%$ 
discharge measurements at flows of $2.6,7.1,31.6$ and 33.7 cfs. The lower and upper inflection points in a plot of the wetted perimeter-discharge relationship occur at flows of 2.0 and $4.0 \mathrm{cfs}$ respectively (Figure 21). Based on an evaluation of the present fishery, results of the wetted perimeter analysis, and estimated water availability, a discharge of $4 \mathrm{cfs}$ is recommended for the low flow period from July 16 through March 31 . Natural flows were observed to decline to below the recommended flow, and at times, in some areas, water flows subsurface, indicating that conditions in Fivemile Creek are below optimum during portions of some water years.

An average depth of $0.5 \mathrm{ft}$, required for successful passage of spawning migrants, is not reached until flows equal or exceed 20.0 cfs (Table 12). A flow of $20.0 \mathrm{cfs}$ is therefore recommended for the period from April 1 through July 15 to ensure migrant passage and protect spawning redds from dewatering.

\section{Grave Creek}

\section{Description}

Stream reach: Grave Creek from its confluence with the Tobacco River (T35N, R26W, Sec. 15) to Foundation Creek (T37N, R24W, Sec. 29) (Figure 22).

Stream Length: $28.3 \mathrm{~km}$. Total drainage area: $191.9 \mathrm{~km}^{2}$. Gradient, $18.5 \mathrm{~m}$ per km.

\section{Source and Land Use}

Grave Creek begins on the western slopes of the Whitefish Mountain Range and flows for $28.3 \mathrm{~km}$ southwest to the Tobacco River. Approximately 14 percent of the lower portion of the watershed is privately owned; the remainder of the drainage is in the Kootenai National Forest. Timber production is the primary land use on the National Forest. Privately owned land is mainly arable, much of which has been put to pasture and forage production.

\section{Flows}

A water stage recording station was maintained by the U.S. Geological Survey, water Resources Division during the 1923 and 1924 water years. Although the records are incomplete and of short duration, monthly means were used to develop an estimated annual hydrograph based on best available data (Figure 23). Estimated mean annual discharge is $88.9 \mathrm{cfs}$. 


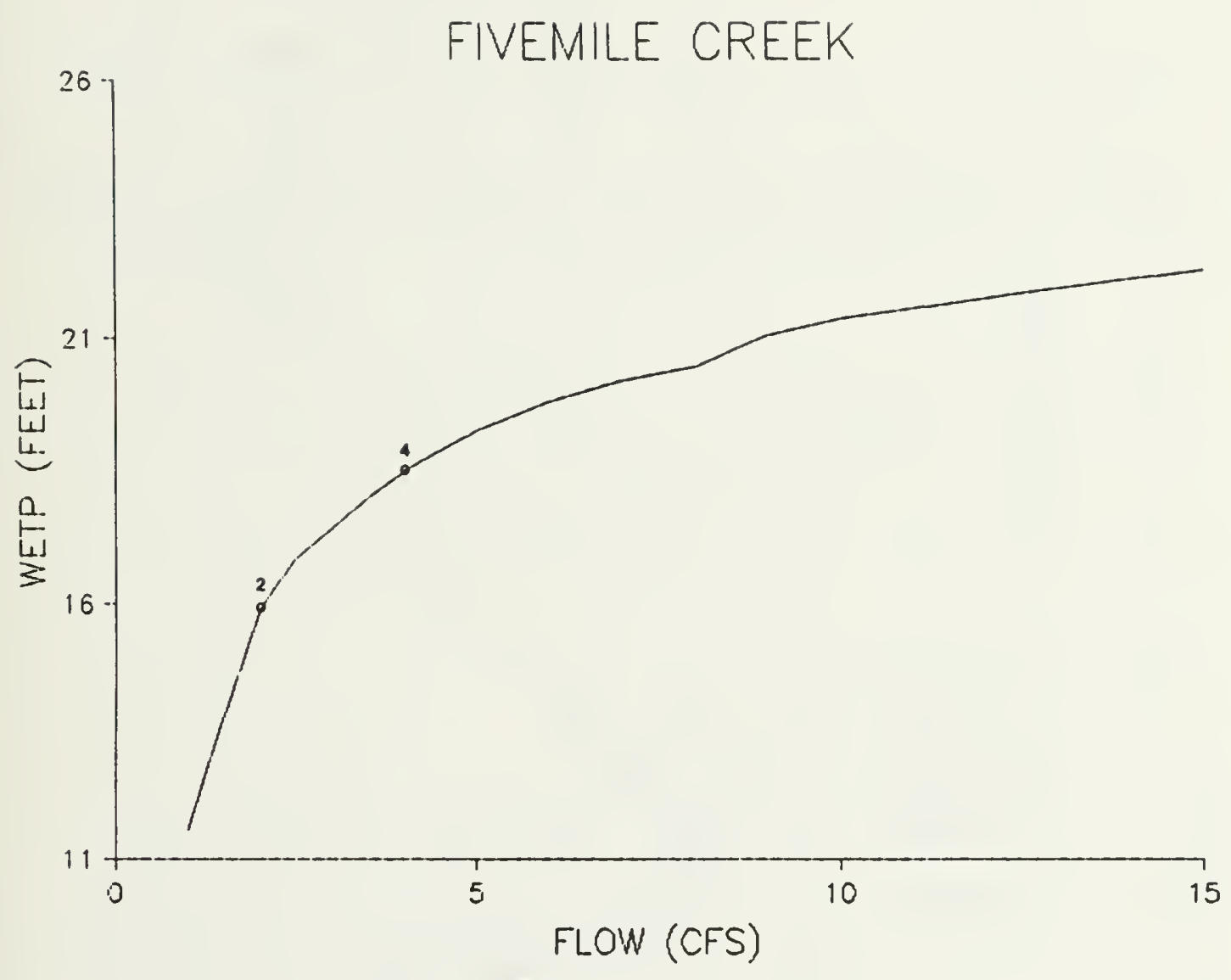

Figure 21. The wetted perimeter-discharge relationship for five riffle transects on Fivemile Creek 1985-1986. 
Table 12. Average depth at five riffle transects in Fivemile Creek at selected flows of interest.

\begin{tabular}{cccccc}
\hline \multirow{2}{*}{$\begin{array}{c}\text { Flow } \\
\text { (cfs) }\end{array}$} & .31 & .28 & .22 & .14 & .41 \\
\cline { 2 - 6 } 2.0 & CS1 & CS2 & CS3 & CS4 & CS5 \\
4.0 & .40 & .36 & .34 & .19 & .52 \\
20.0 & .67 & .69 & .79 & .52 & .77 \\
\hline
\end{tabular}



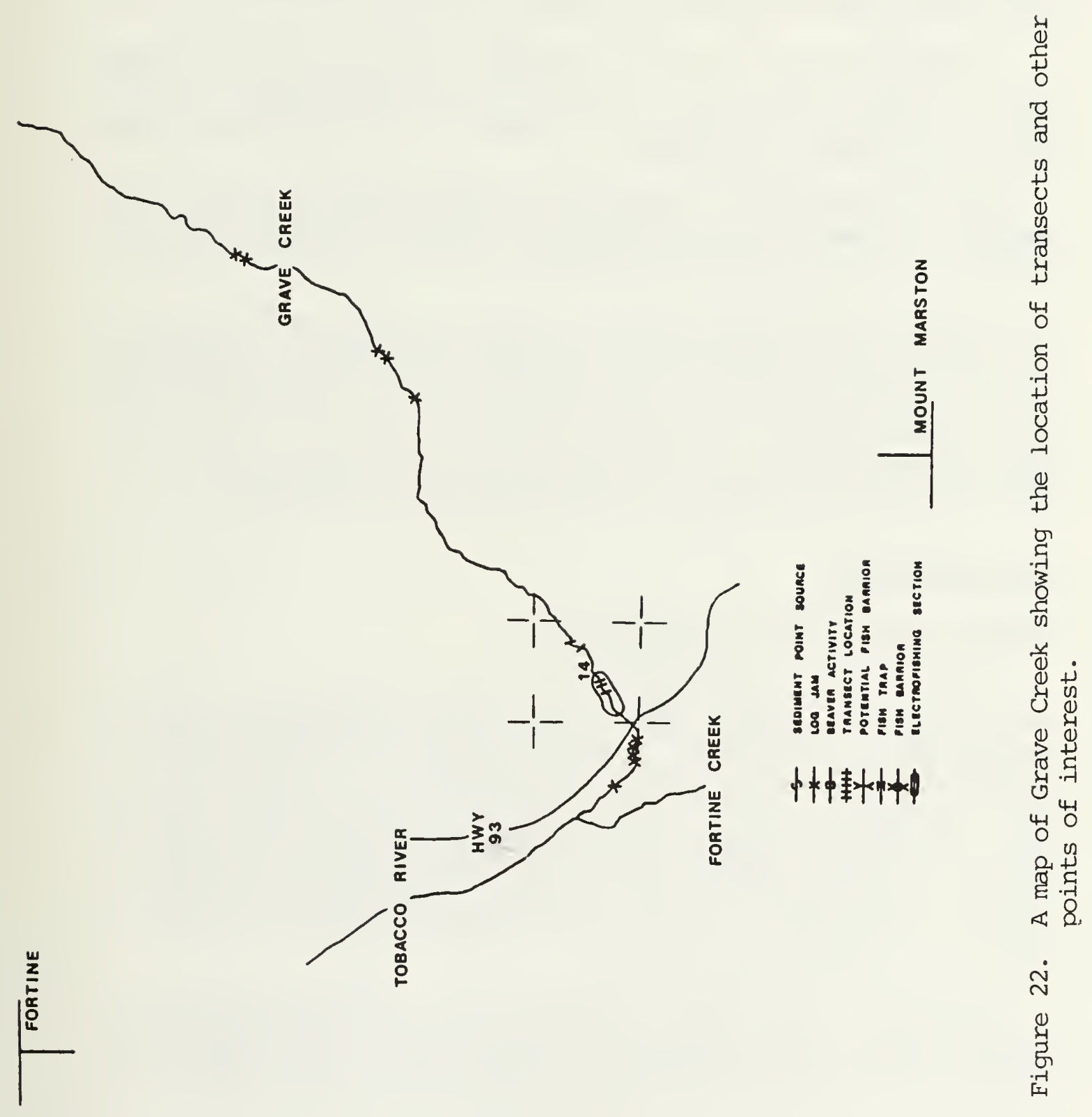
Water appropriations listed for Grave Creek total $80.8 \mathrm{cfs}$ not including amounts allocated for livestock which are issued on the basis of stock type and herd size (Index of Claims, State Water Rights, Helena, Montana). If all water users exercise their water rights to the fullest extent, the stream would be dewatered during most of the water year. It is unknown, however, what number of claims are valid or presently in use.

Livestock access to Grave Creek is unrestricted in many pasture lands bordering the lower $6 \mathrm{~km}$ of the stream. Bank erosion and sediment loading has apparently been accelerated by grazing and forage production.

Timber harvest and associated road building could also increase sediment loading and peak flows, causing channel instability and damage to fish habitat.

Source tributaries (Blue Sky, Clarence, Stahl and Williams creeks) have been targeted for microhydro development. Although original applications on the former three creeks were subsequently withdrawn, the application on Williams Creek is still pending and future development is anticipated in the drainage when the region's power surplus declines and cost-benefit ratios improve, making hydroelectric projects more attractive to developers.

\section{FISH POPULATIONS}

\section{Resident, Pre-emigrant and Migrant Fish}

A mark-recapture population estimate was conducted on a representative 324.9-m section chosen for its location between natural constrictions in the stream. Game fish captured were predominated by Salmo spp. and a relatively smaller population of eastern brook trout (Table 13). Length-frequency histograms present modal lengths (Appendix A9 and Al0). Based on recaptures and catch efficiency results (Appendix All), all length groups were pooled. One male kokanee salmon and a mountain whitefish were also included in the catch. Two other ripe kokanee observed in a pool escaped our electrofishing effort.

Grave Creek is a major producer of bull trout recruits to Libby Reservoir. Since 1983, personnel of the Montana Department of Fish, Wildlife and Parks have conducted annual bull trout redd 
Table 13. Results of a mark-recapture estimate conducted on Grave Creek (T35N, R26W, Sec. 14, SE-1/4) during September 1986. Discharge 42.8 cfs.

Total Number

Captured
Estimated Number Fish $\geq 75 \mathrm{~mm}$ per $1 \mathrm{~km}$

Salmo spp.a/

83

$428 \pm 151$

eastern brook trout

22

$142 \pm 105$

a) Species composition: $\mathrm{RB}=73.5 \%, \mathrm{WCT}=7.2 \%, \mathrm{HYB}=19.3 \%$ 
GRAVE CREEK

estimated onnual hydrogroph

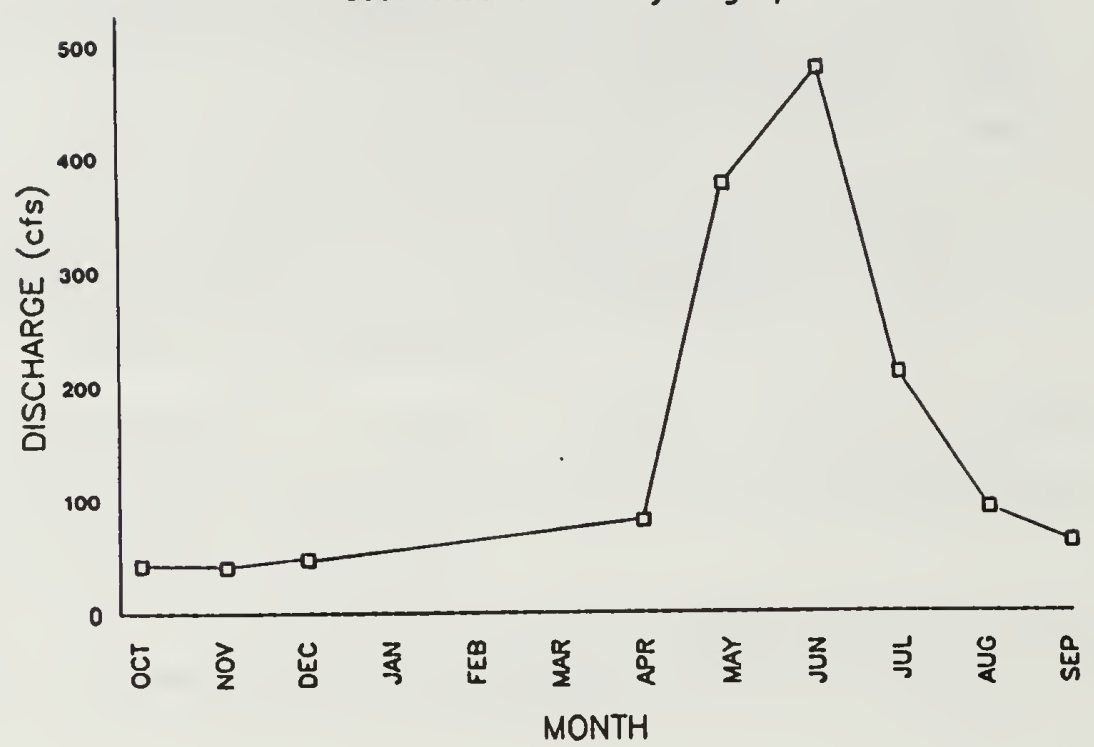

Figure 23. An estimated annual hydrograph for Grave Creek based on USGS daily stage-discharge measurements during previous water years, and miscellaneous measurements.

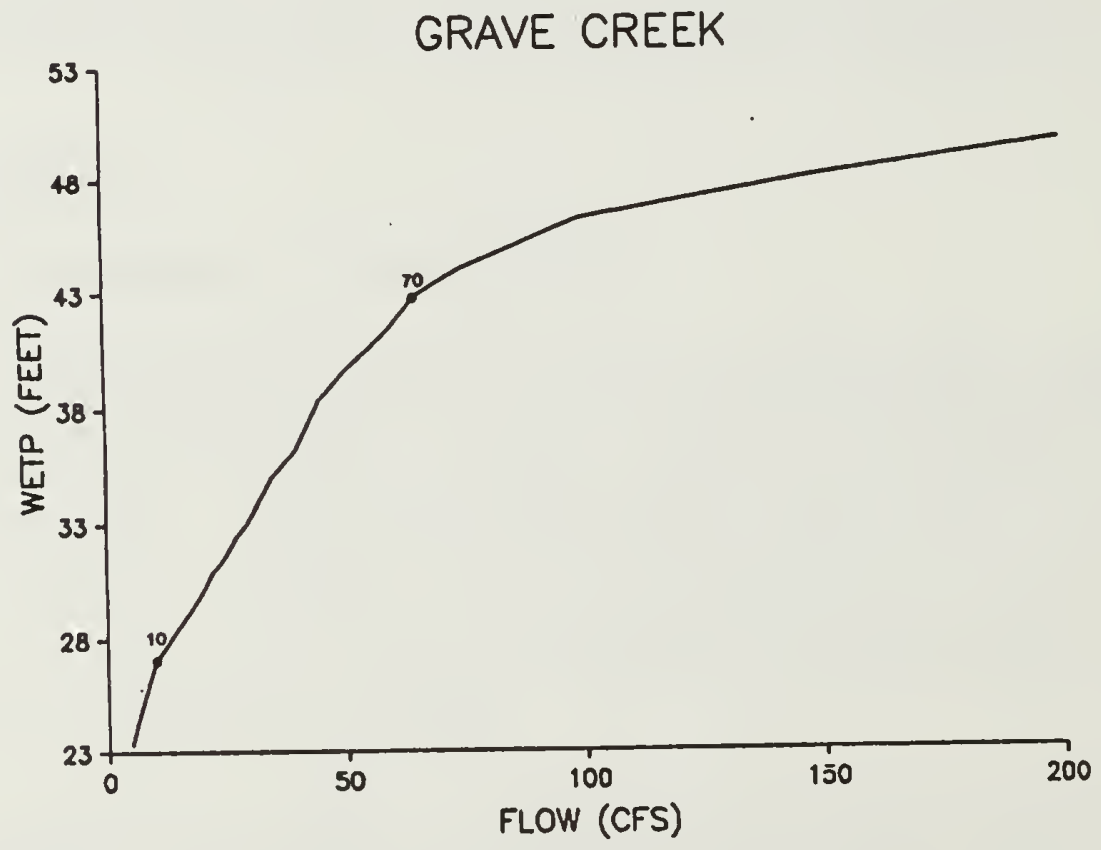

Figure 24. The wetted perimeter-discharge relationship for five riffle transects on Grave Creek 1985-1986. 
surveys on Grave Creek and its major tributaries. Redds were located in Grave and Clarence creeks. Results are as follows:

$\begin{array}{llcc} & \text { Grave Creek } & \text { Clarence Creek } \\ 1983 & \text { definite } & 40 & 31 \\ & \text { probable } & 8 & 6 \\ 1984 & \text { definite } & 22 & 12 \\ & \text { probable } & 1 & 0 \\ 1985 & \text { definite } & 24 & 3 \\ & \text { probable } & 9 & 2\end{array}$

\section{FLOW RECOMMENDATIONS}

Five permanent transects were established on riffle areas located approximately $1 \mathrm{~km}$ upstream from the Highway 93 bridge (T35N, R26W, Sec. 14, S-1/2). The WETP program was calibrated to stage and discharge measurements at flows of 73.0, 97.9, and 188.5 cfs. The lower and upper inflection points in a plot of the wetted perimeter-discharge relationship occur at flows of 10 and $70 \mathrm{cfs}$, respectively (Figure 24). Based on an evaluation of the existing fishery, results of the wetted perimeter analysis and estimated water availability, a minimum discharge of $70 \mathrm{cfs}$ is recommended for the low flow period from July 16 through March 31.

An average depth of $0.5 \mathrm{ft}$ required for successful passage of spawning migrants is not reached until flows equal or exceed $70 \mathrm{cfs}$ (Table 14). A minimum passage flow of $70 \mathrm{cfs}$ is therefore recommended for the period from April 1 through July 15 to assure migrant passage and protect spawning redds from dewatering.

\section{Tobacco River}

\section{Description}

Stream reach: Tobacco River from the mouth on the eastern shore of Libby Reservoir (T36N, R27W, Sec. 8) to the confluence of Fortine and Grave Creek (T35N, R26W, Sec. 15) (Figure 25).

Stream length: $24 \mathrm{~km}$. Total drainage area: $1,135.2 \mathrm{~km}^{2}$. Gradient: $6.3 \mathrm{~m}$ per $\mathrm{km}$.

\section{Source and Land Use}

The Tobacco River forms at the junction of its two major tributaries, Fortine and Grave creeks. Fortine Creek begins on the east slopes of the Salish mountains and flows north for 45.1 $\mathrm{km}$ to its junction with Grave Creek. Grave Creek forms on the western slopes of the Whitefish Mountains and flows southwest for $28.3 \mathrm{~km}$ to the Tobacco River. Approximately 24 percent of the Tobacco Drainage is privately owned; the remainder is in the 
Table 14. Average depth in five riffle transects on Grave Creek at selected flows of interest.

\begin{tabular}{lllllll}
\hline \multirow{2}{*}{$\begin{array}{c}\text { Flow } \\
\text { (cfs) }\end{array}$} & \multicolumn{6}{c}{ Average depth (ft) } \\
\cline { 2 - 6 } 10.0 & .50 & .30 & .36 & .43 & .28 \\
70.0 & .83 & .51 & .81 & .85 & .59 \\
\hline
\end{tabular}




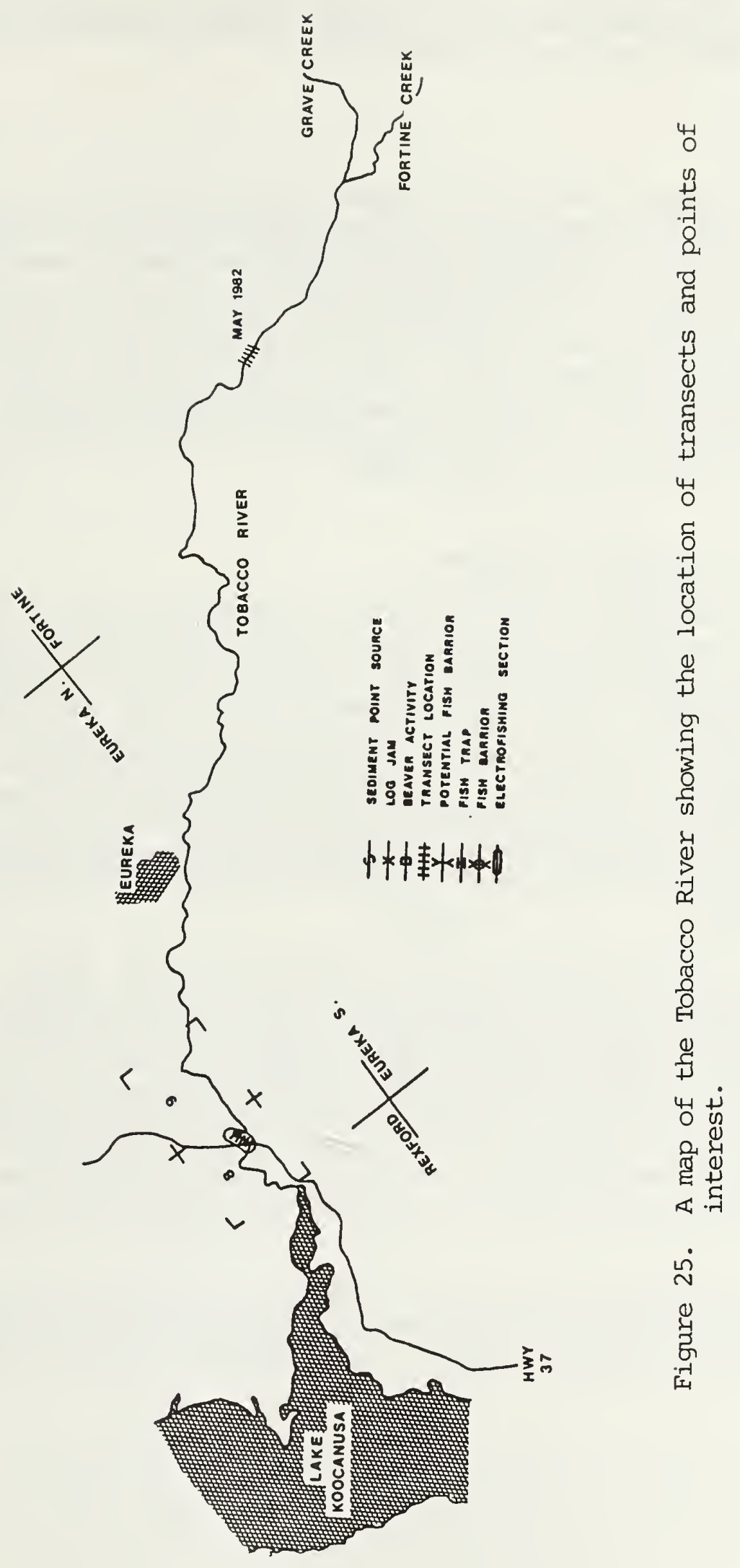


Kootenai National Forest. Timber production is the primary land use in the watershed. The lower drainage contains extensive arable lands in pasture and forage production.

\section{Flows}

A continuously recording stage-discharge station was maintained by the U.S. Geological Survey, Water Resources Division from October 1958 through September 1965 and from October 1967 through September 1985 (T36N, R27W, Sec. 9). Monthly mean flows based on 28 years of daily stage measurements and associated eightieth percentile exceedence flows are summarized in Figure 26. Mean annual discharge is $268.7 \mathrm{cfs}$. A wetted perimeter analysis was performed by the Montana Department of Fish, Wildlife and Parks approximately $1.6 \mathrm{~km}$ upstream from the mouth of Therriault Creek (T35N, R26W, Sec. 4) (May 1982).

\section{Potential Environmental Problens}

Water appropriations listed for the Tobacco River total $201.8 \mathrm{cfs}$, amounting to 75 percent of the 28 -year mean annual discharge of 268.70 cfs (Index of Claims, State water Rights, Helena, Montana). This total does not include water allotments for livestock nor water allocations on source tributaries which are apparently over-appropriated (see Grave and Deep creeks). If all water users exercise their water rights to the fullest extent, the Tobacco River could potentially become dewatered. It is not known, however, what percentage of existing claims are valid or presently in use. Future water rights will increase the potential for dewatering.

Source tributaries (Blue Sky, Clarence, Deep, Stahl, and Williams creeks) have been targeted for microhydro development. Although the former four applications were later withdrawn, the application on Williams Creek is still pending and future development in the drainage is anticipated when the region's power surplus declines and cost-benefit ratios improve making hydroelectric projects once again more attractive to developers. The watershed will be impacted by hydroelectric projects if they are installed, reducing habitat for migrant and rearing fish populations.

Sediment pollution from timber harvest and associated road building, and agricultural practices will continue to be a problem in the future. Sediment loading is most severe in Fortine Creek. 


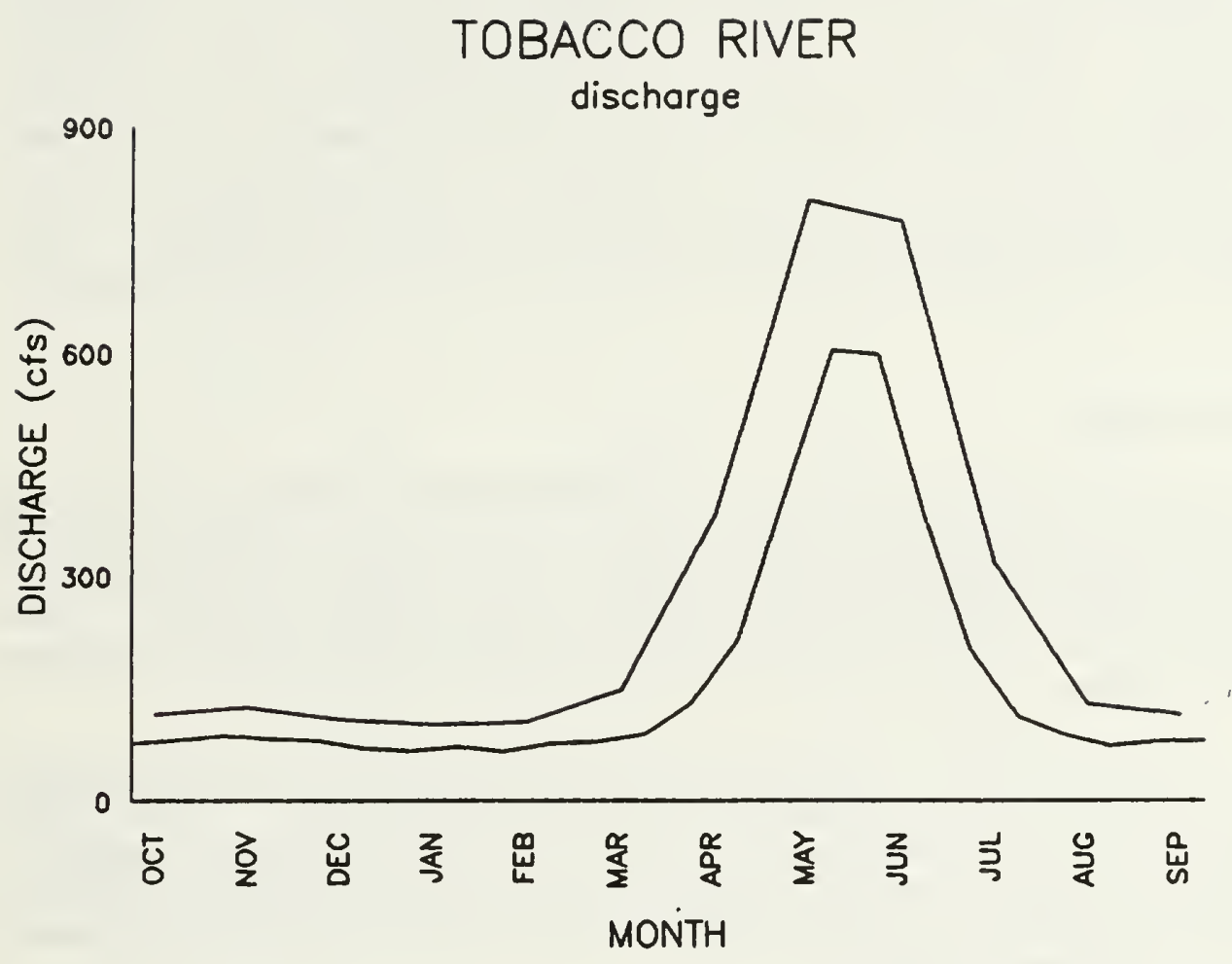

Figure 26. Mean monthly flows (top line) and eightieth percentile exceedence flows (bottom line) based on 28 years of daily stage records for the Tobacco River (USGS). 


\section{Resident and Pre-emigrant Fish}

A mark-recapture population estimate was conducted during September, 1985 in a representative 609.6-m section of stream chosen for its location between two shallow riffle areas encompassing the study transects (T36N, R27W, Sec., 8). Game fish were predominantly Salmo spp. (species composition: RB=96.6\%, $W C T=1.7 \%$, HYB=1.7\%). A total of 60 Salmo spp. were captured, producing an estimate of $156 \pm 62 \mathrm{fish}(\geq 75 \mathrm{~mm})$ per $\mathrm{km}$. A lengthfrequency histogram reveals modal lengths (Appendix Al2). Based on recaptures and a catch efficiency curve (Appendix Al3), all length categories were pooled. Relatively smaller numbers of bull trout (1) and mountain whitefish (10) were also captured. Discharge corresponding with the electrofishing survey was 89.4 cfs.

\section{Migrant Fish}

A point estimate based on a mark-recapture study of the spring spawning run disclosed that an estimated 5,937 rainbow and 516 westslope cutthroat trout utilized Tobacco River as a spawning area in 1976 (May and Huston 1980). May (1982) stated, "... the Tobacco River is the most important spawning and rearing drainage in the Montana portion of the Lake Koocanusa system."

The Tobacco River supports the largest spawning run of kokanee salmon of all U.S. Kootenai River tributaries. The 1985 immigration was estimated at 3,000 to 5,000 spawners, based on aerial survey (Personal Communication, Paul Hamlin, MDFWP). Spawning kokanee are harvested by sportsmen during the annual salmon snagging season.

\section{FLOW RECOMMENDATIONS}

Five permanent transects were established in a series of five riffle areas of the Tobacco River upstream from the Highway 37 bridge (T36N, R27W, Sec. 8). The WETP program was calibrated to stage and discharge measurements at flows of 101.1, 170.0, and 451.0 cfs. The lower and upper inflection points in a plot of the wetted perimeter-discharge relationship occurred at 70 and 120 cfs, respectively (Figure 27). Based on a reanalysis of data compiled on the Tobacco River by May 1982 at a station approximately $1.6 \mathrm{~km}$ upstream from the mouth of Therriault Creek, inflection points occurred at 65 and $95 \mathrm{cfs}$ (Figure 28).

An average depth of $0.5 \mathrm{ft}$ required for fish passage is met in all riffle transects when the flow equals or exceeds 32 cfs in the lowe portion of the Tobacco River (Table 15). Since the minimum flow recommendation for all periods of the year exceeds the minimum depth limit for successful passage, migration should not 


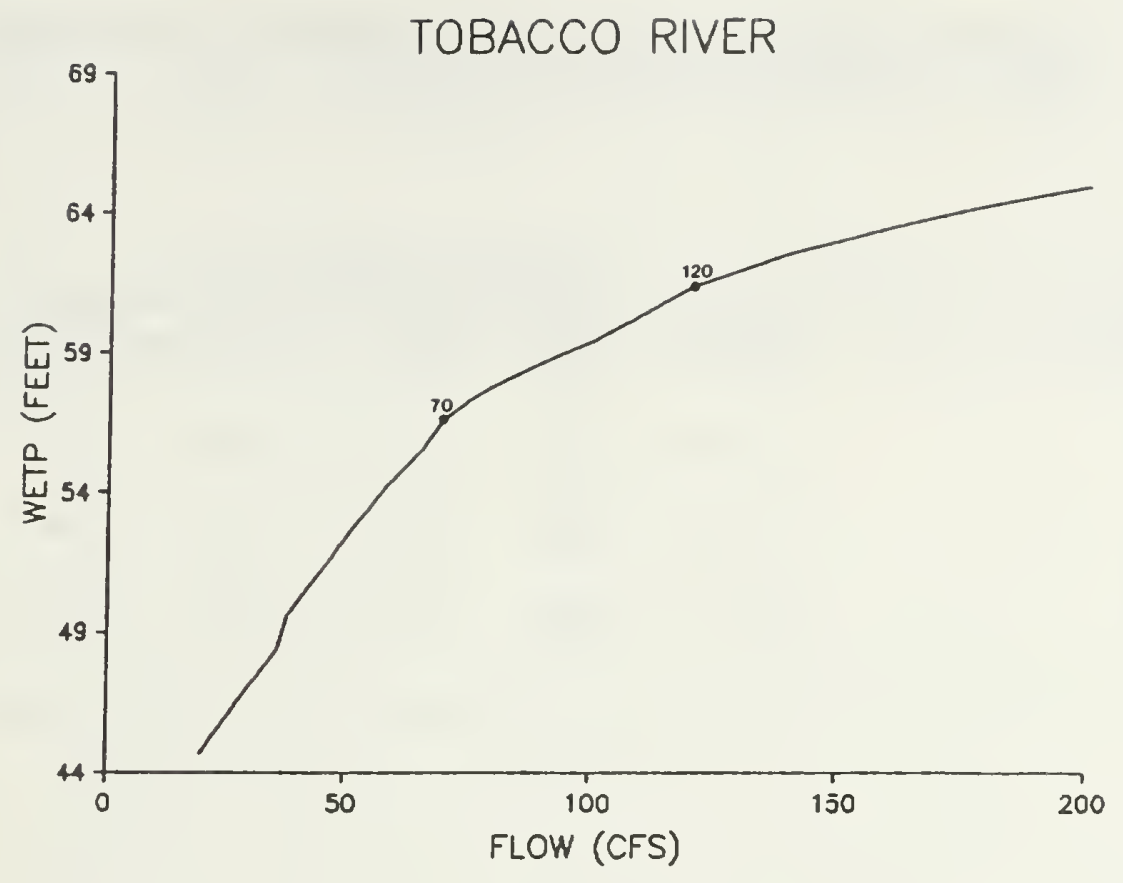

Figure 27. The wetted perimeter-discharge relationship for five riffle transects on the Tobacco River 1985-1986.

\section{TOBACCO RIVER}

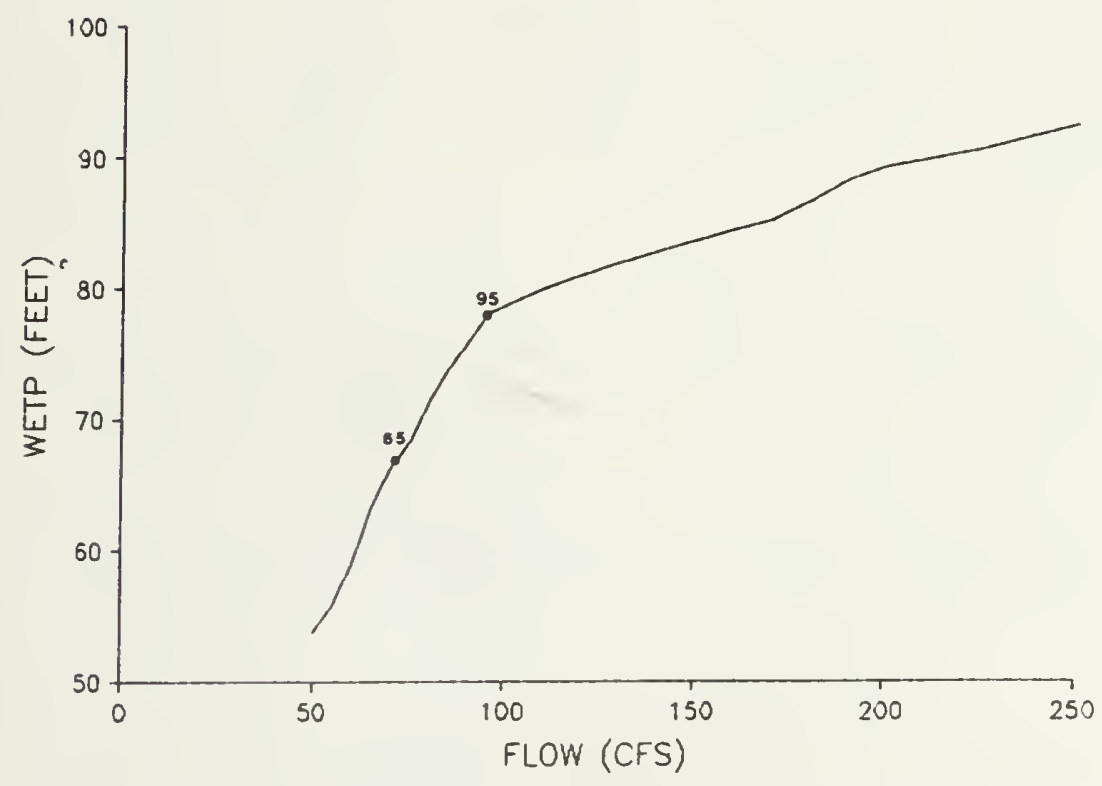

Figure 28. The wetted perimeter-discharge relationship for five riffle transects on the Tobacco River (May 1982). 
Table 15. Average depth for five riffle transects in the Tobacco River at selected flows of interest.

\begin{tabular}{ccccccc}
\hline \multirow{2}{*}{$\begin{array}{c}\text { Flow } \\
\text { (cfs) }\end{array}$} & \multicolumn{6}{c}{ Average depth } \\
\cline { 2 - 6 } & CS1 & CS2 & CS3 & CS4 & CS5 \\
\hline 32 & .59 & .67 & 1.02 & .50 & 1.15 \\
70 & .80 & .89 & 1.01 & .74 & 1.46 \\
120 & 1.05 & 1.09 & 1.16 & 1.02 & 1.72 \\
\hline
\end{tabular}


be inhibited if instream flow recommendations are instituted as stated. A depth of $0.5 \mathrm{ft}$ is not reached at all upper transects until flows equal or exceed $110 \mathrm{cfs}$ (Table 16). A fish passage flow of $110 \mathrm{cfs}$ is recommended for the period from April 1 through July 15.

The results of both studies were combined for an overall recommendation for the Tobacco River (Table 17). Recommended flows amount to 47.1 percent of the mean annual discharge on record. 
Table 16. The average depth for five riffle cross-sections in upper Tobacco River at selected flows of interest May 1982).

\begin{tabular}{rrrrrr}
\hline \multirow{2}{*}{$\begin{array}{c}\text { Flow } \\
\text { (cfs) }\end{array}$} & \multicolumn{6}{c}{ Average depth } & (ft) \\
\cline { 2 - 6 } & CS1 & CS2 & CS3 & CS4 & CS5 \\
\hline 65 & .35 & .79 & .91 & .56 & .45 \\
95 & .46 & .66 & .81 & .69 & .49 \\
110 & .51 & .70 & .87 & .73 & .54 \\
\hline
\end{tabular}


Table 17. Recommended minimum flows for the Tobacco River and historical water availability records based on 28 years of daily records (USGS).

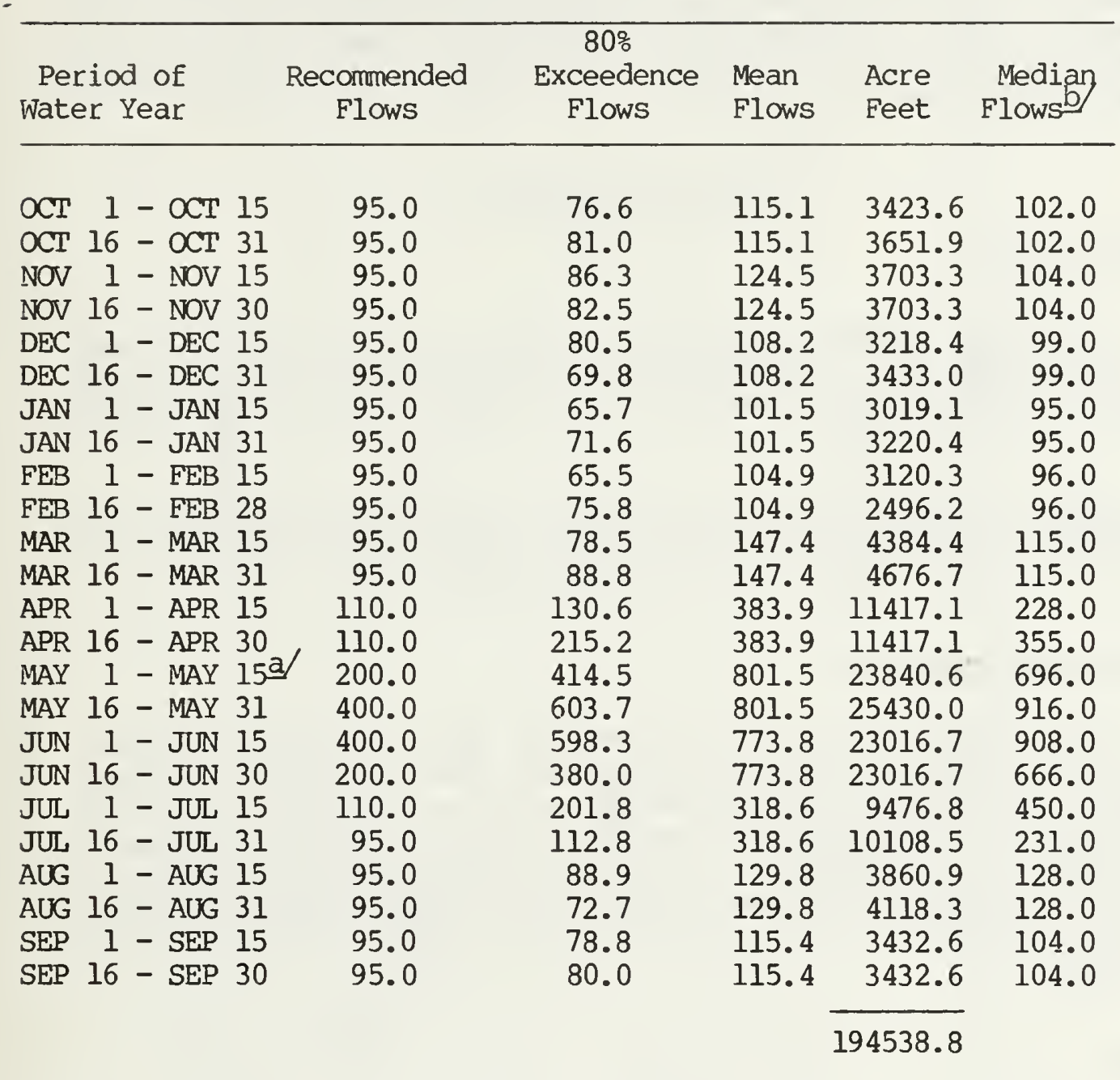

a) A dominant discharge flow (approximated bankful discharge presently undefined) should be maintained for 24 hours during this period.

b/ Derived from a nine-year period of record (between 1965 and 1973) for the USGS gauge near Eureka $(4.5 \mathrm{~km}$ upstream from mouth) (May 1982). 
Tributaries to the main stem Kootenai River below Libby Dam provide a great majority of recruits to the river fishery. In addition, the tributaries supply nutrients and food items such as benthic drift and prey fish populations. The following is a discussion of some of the tributaries identified as high priority spawning and rearing streams

\section{Big Cherry Creek}

\section{Description}

Big Cherry Creek (this reach is also listed as Granite Creek on some maps) from the mouth on Libby Creek (T30N, R3lW, Sec. 14) to the confluence of Granite and Big Cherry creeks (T29N, R31W, Sec. 2) (Figure 29).

Stream length: $6.8 \mathrm{~km}$. Total drainage area: $221.6 \mathrm{~km}^{2}$. Gradient, Big Cherry Creek from Libby Creek to the confluence of Granite and Big Cherry Creek: $11.6 \mathrm{~m}$ per km.

\section{Source and Land Use}

Big Cherry Creek arises on the east face of the Cabinet Mountains in two major streams, Granite and Big Cherry creeks. Discharge from both streams combine and flow $6.8 \mathrm{~km}$ to merge with Libby Creek. Approximately 8 percent of the watershed is privately owned; the remainder is in the Kootenai National Forest. The headwaters drain portions of the Cabinet Mountain Wilderness. Timber production and mining are the primary land uses in the drainage.

\section{Flows}

A continuous stage recording station was maintained on Granite Creek by the U.S. Geological Survey from January through December 1933, August 1936 through November 1943, and August 1960 through October 1969. Mean monthly discharge and eightieth percentile exceedence flows for Granite Creek are presented in Figure 30. Little flow information exists for Big Cherry Creek which delivers a significant volume of water to the study area.

\section{Potential Environmental Problems}

Timber harvesting, mining and construction activities (especially surrounding the lower $5 \mathrm{~km}$ of the stream) in the watershed have increased sediment loading and peak flows resulting in channel stability problems and damage to the fish habitat. 


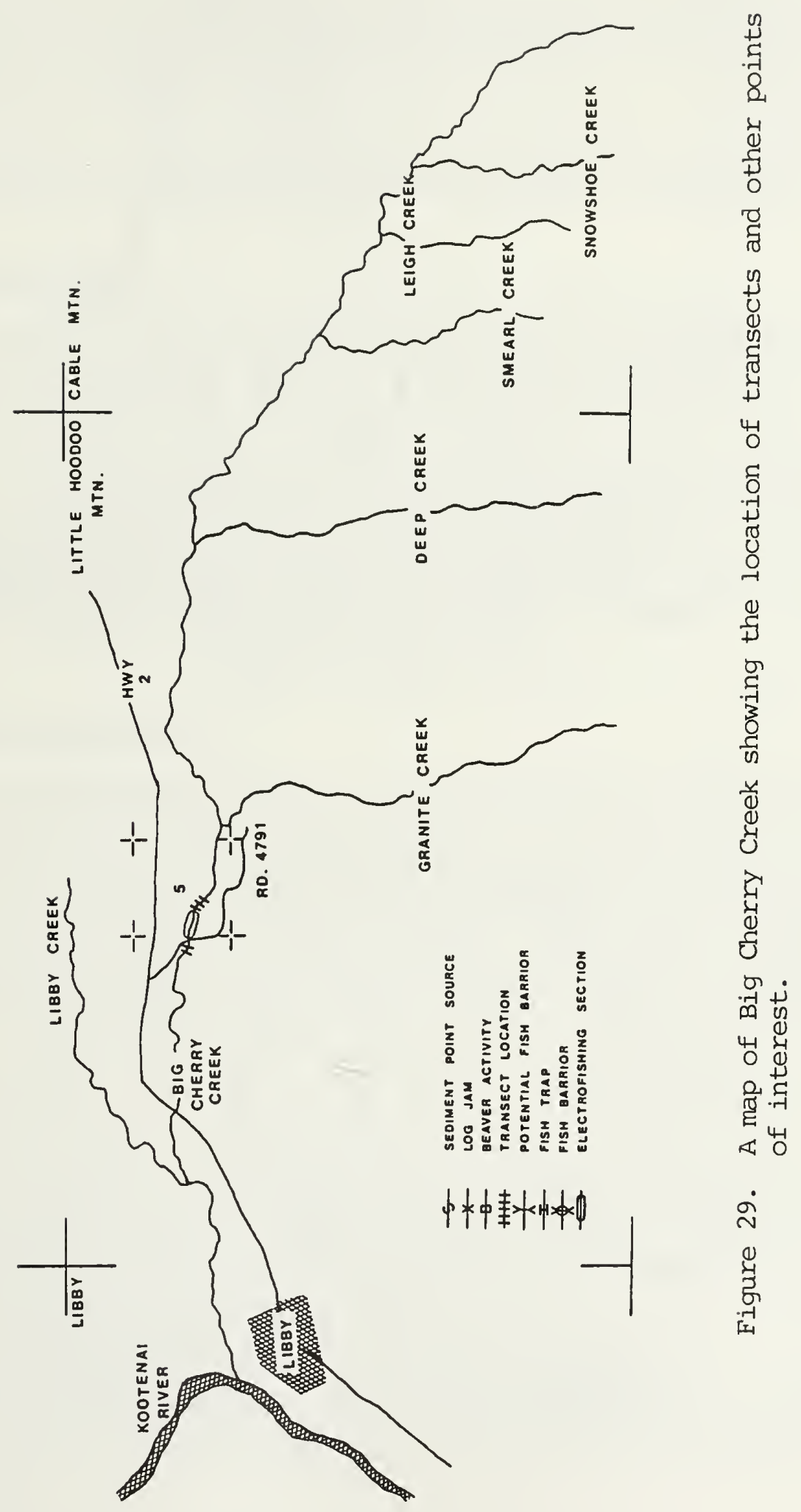


GRANITE CREEK dischorge

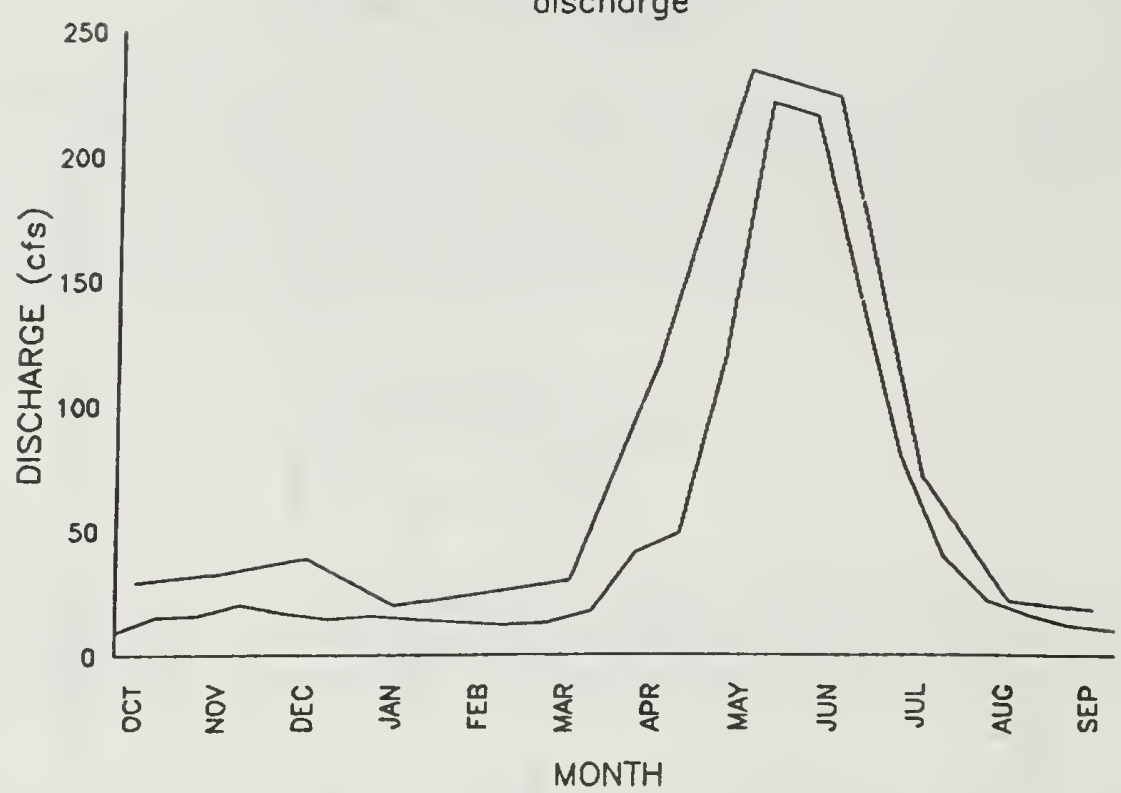

Figure 30. Mean monthly flows (top line) and eightieth percentile exceedence flows (bottom line) based on ten years of daily stage records for Granite Creek (USGS). (Big Cherry Creek probably has similar hydrologic conditions.)

BIG CHERRY CREEK

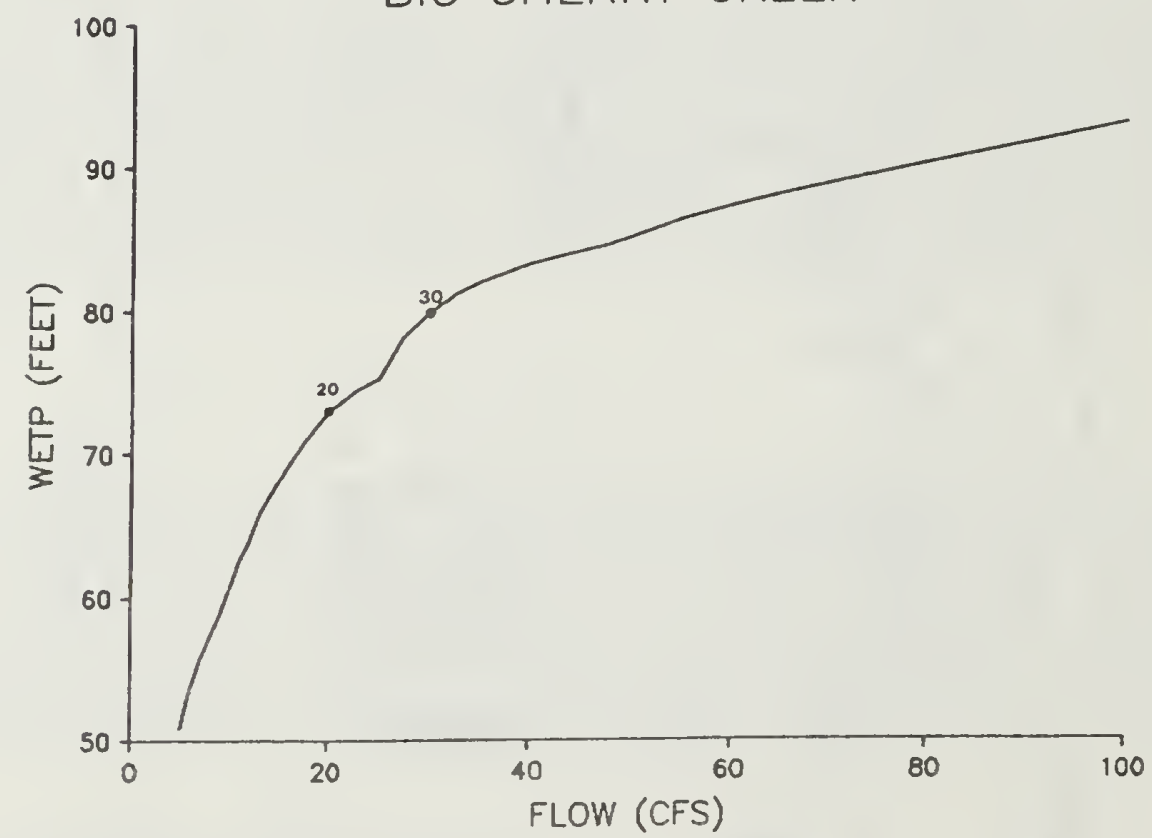

F'igure 31. The wetted perimeter-discharge relationship for four riffle transects on Big Cherry Creek below the confluence of Granite and Big Cherry creeks 1985-1986. 
Water appropriations for domestic use and mining total $33.14 \mathrm{cfs}$ for Granite Creek alone. If water users exercise their water rights to the fullest extent, water in the reach below the confluence of Granite and Big Cherry Creeks could potentially reach extremely low levels, impacting available fish habitat. It is unknown, however, what portion of existing claims are valid or presently is use.

Pollution from an abandoned mine on Snowshoe Creek is limiting productivity in Showshoe and Big Cherry Creeks (May 1982).

\section{FISH POPULATIONS}

A mark-recapture population survey was conducted during August, 1986, in a 304.8-m section of stream chosen for its habitat characteristics which are representative of much of the stream and its location between two shallow riffle areas (T30N, R3lW, Sec. 35). Game fish were composed primarily of rainbow trout (75), yielding an estimate of $873 \pm 604 \mathrm{fish} \geq 75 \mathrm{~mm}$ per $\mathrm{km}$, and relatively fewer numbers of eastern brook trout (4). The sparse population in this reach, characterized by channel instability, resulted in a limited sample size. A length-frequency histogram shows modal length of rainbow trout captured (Appendix Al4). Associated discharge was $24.3 \mathrm{cfs}$.

\section{FLOW RECOMMENDATIONS}

Five permanent transects were established in riffle areas in Big Cherry Creek from approximately 0.4 to $1.6 \mathrm{~km}$ downstream of the confluence of Granite and Big Cherry Creeks (T30N, R3IW, Sec. 35). One transect was dropped due to channel morphology changes which occurred during the study period. Therefore, flow considerations were based on four transects. The WETP program was calibrated to stage and discharge measurements at flows of 20.8, 24.2, 274.2 and $444.2 \mathrm{cfs}$. Lower and upper inflection points in a plot of the wetted perimeter-discharge relationship occur at 20 and $30 \mathrm{cfs}$, respectively (Eigure 31). Based on existing fish populations, results of the wetted perimeter analysis and estimated water availability a flow of $20 \mathrm{cfs}$ is recommended for the low flow period from July through March 31 . Since flow characteristics change significantly above the confluence of Granite and Big Cherry creeks, further research is recommended to clarify discharge requirements in the two major water sources. Combined flows should equal or exceed minimum recommendations set for the lower reach of the stream.

An average depth of $0.5 \mathrm{ft}$ is not reached in all transects until the flow equals or exceeds $50 \mathrm{cfs}$ (Table 18). A passage flow of $50 \mathrm{cfs}$ is therefore recommended from April 1 through June 30 to ensure successful migration of fish during the spring spawning run. 
Table 18. The average depth for four riffle cross-sections on Big Cherry Creek at selected flows of interest.

\begin{tabular}{ccccc}
\hline \multirow{2}{*}{$\begin{array}{c}\text { Flow } \\
\text { (cfs) }\end{array}$} & Average depth (ft) & \\
\cline { 2 - 5 } 20 & 1.51 & .53 & .37 & .42 \\
30 & 1.32 & .66 & .42 & .51 \\
50 & 1.49 & .85 & .50 & .63 \\
\hline
\end{tabular}




\section{Callahan Creek}

\section{Description}

Stream reaches: Lower Callahan Creek from the mouth on the Kootenai River near Troy, Montana ( $T 31 \mathrm{~N}, \mathrm{R} 34 \mathrm{~W}$, Sec. 13) to a $2.4-\mathrm{m}$ falls and 7.62-m long cataract believed to be a barrier to migrant fish (T3IN, R34W, Sec. 21). And Upper Callahan Creek from the falls to the source (T60N, R2E, Sec 34) in Idaho. Callahan Creek crosses the Montana Idaho border at T31N, R34W, Sec. 23) (Figure 32).

Stream length: mouth to falls, $8 \mathrm{~km}$; falls to source, $12.8 \mathrm{~km}$. Total drainage: $211.7 \mathrm{~km}^{2}$. Gradient: mouth to falls, 24.9; falls to source, $29.6 \mathrm{~m}$ per $\mathrm{km}$.

\section{Source and Land Use}

Callahan Creek originates on the eastern slopes of the West Cabinet Mountains and flows east for $20.8 \mathrm{~km}$ to the Kootenai River. Other than a few parcels of privately owned land and land belonging to Champion International in eight sections of the drainage, the entire watershed is in the Kootenai National Forest. The lower approximately $2 \mathrm{~km}$ flows through the southern portion of the city of Troy, Montana. Upstream, the creek is bordered by National Forest land except for a narrow strip at the Snowstorm Mine, which is privately owned.

\section{Flows}

The U.S. Geological Survey, Water Resources Division maintained a continuously recording stage-discharge station for July through June 1911 and October and April through June 1912 (T31N, R34W, Sec. 13). Although records do not include continuous data for the entire water years, a hydrograph was constructed based on best available data (Figure 33). Estimated mean annual discharge is 136.4 cfs.

\section{POTENTIAL ENVIRONMENTAL PROBLEMS}

Many steep slopes within the Callahan drainage are composed of fine materials easily erodable by timber harvest activities and associated road building. A potential exists for sediment loading. Channel stability is poor in areas above and below the deeply incised canyon area.

Remnants of past mining endeavors remain in the stream below the Snowstorm mine site. 


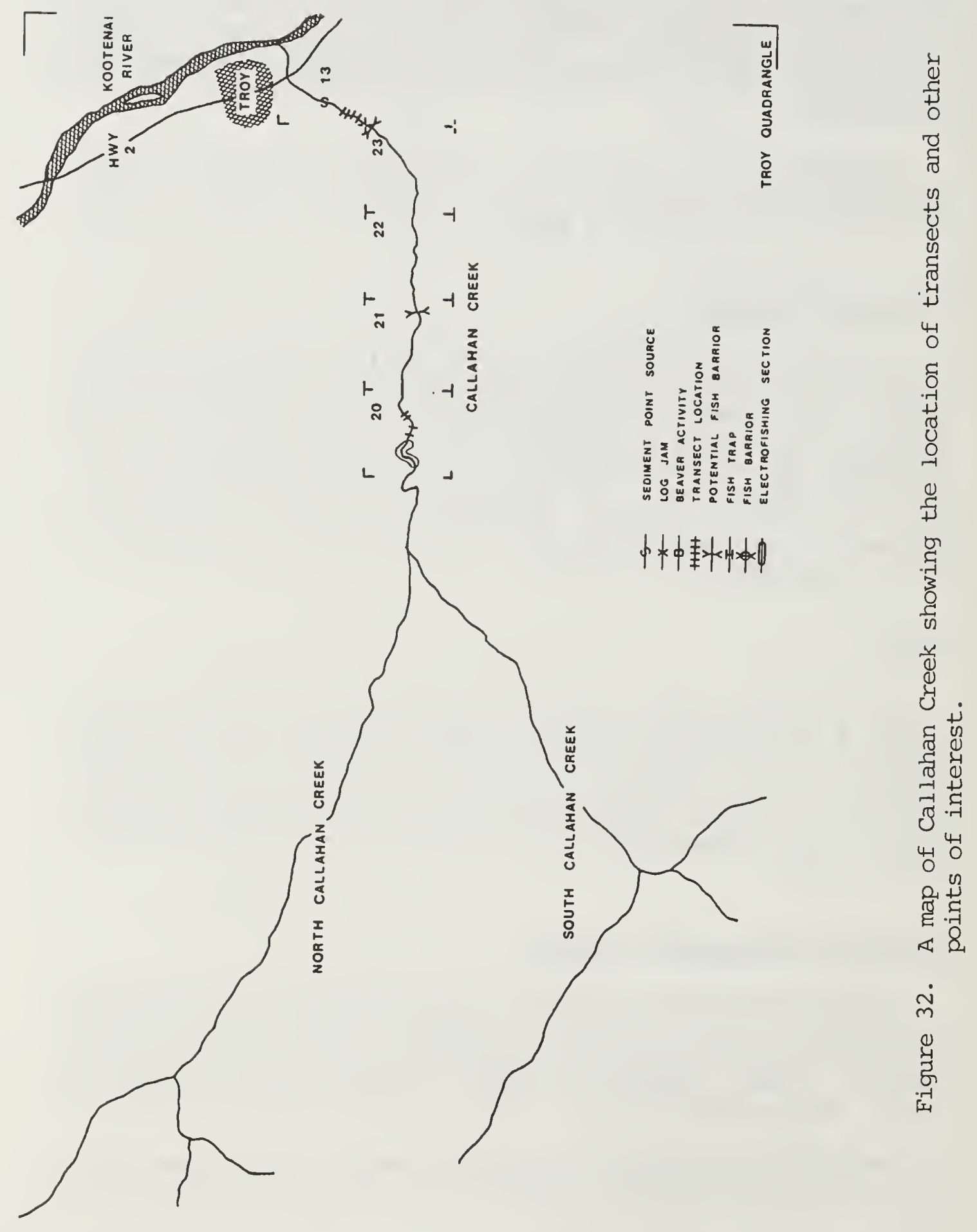




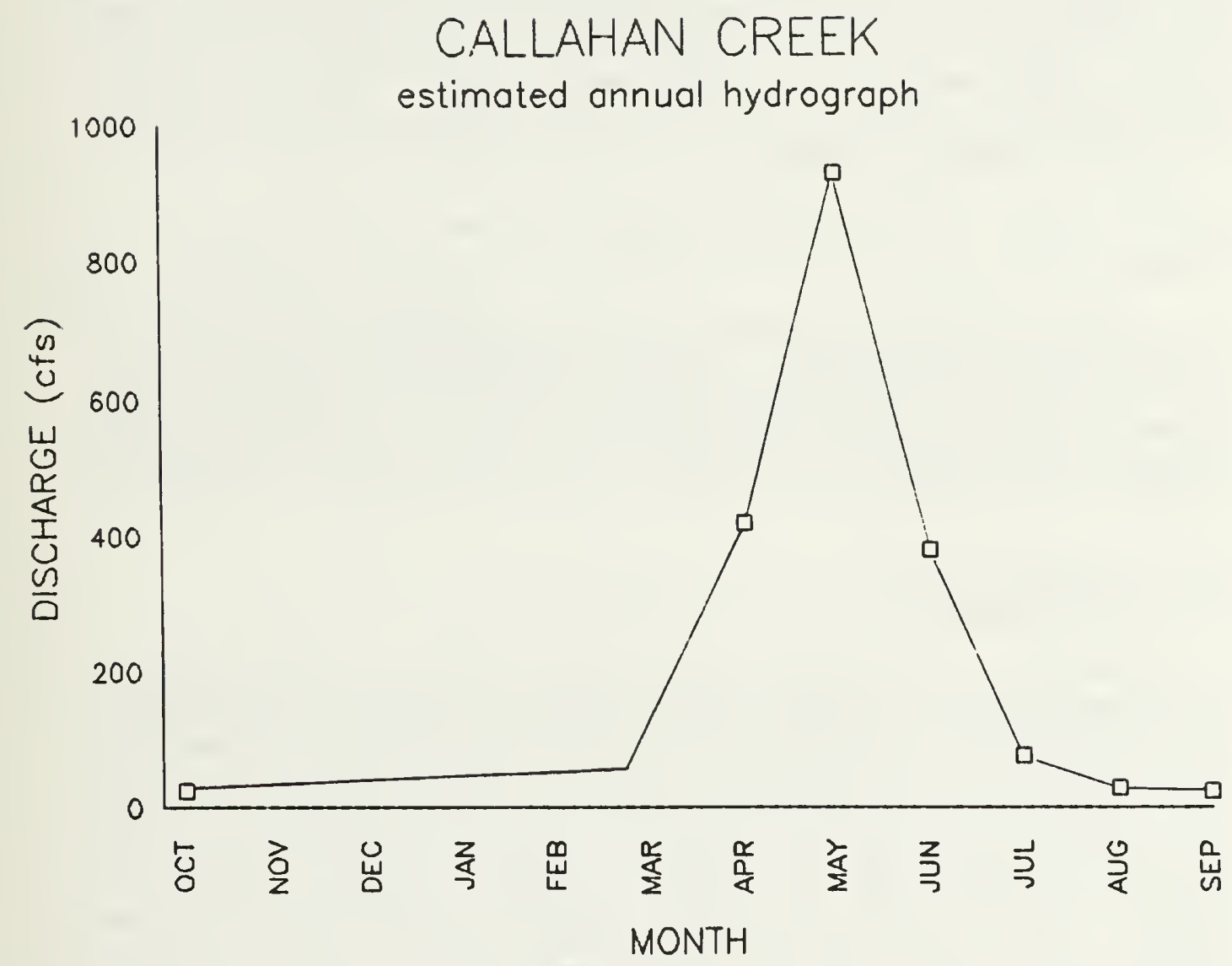

Figure 33. An estimated annual hydrograph for Callahan Creek based on USGS daily stage-discharge measurements during the 1911 and 1012 water years, and miscellaneous measurements. 


\section{Resident Fish}

A mark-recapture population assessment was conducted in a representative $228.6-\mathrm{m}$ section of stream chosen for its location between two channel constrictions. Game fish were predominantly pure-strain inland rainbow endemic to the Callahan drainage (Allendorf and Phelps 1980) and fewer numbers of bull trout (Table 19). Length-frequency histograms show modal lengths (Appendix A15). The native rainbow trout in upper Callahan Creek are genetically isolated from Kootenai River rainbow which have become hybridized with a coastal form. It is believed that the falls located between lower and upper Callahan Creek is a barrier to migrants from the river, creating a boundary between the two dissimilar genetic strains.

\section{Migrant Fish}

A spring spawning run of riverine Salmo spp. was observed entering Callahan Creek. Access is apparently available for spawning migrants only in the lower $8.0 \mathrm{~km}$ of the tributary. High flows precluded migrant trapping, however, one large female rainbow trout $(540 \mathrm{~mm}, 2,127.3 \mathrm{~g})$ was successfully captured, tagged and released.

\section{FLOW RECOMMENDATIONS}

A total of 9 transects were established in riffle areas on Callahan Creek, four above (T3IN, R34W, Sec. 20), and five below the probable fish barrier (T3IN, R34W, Sec. 22). One transect in the lower section was washed out prior to completion of the study. Consequently calculations are based on four transects in each area. The wetted perimeter program was calibrated to stage and discharge measurements at flows of $31.3,61.3,180.1$ below the barrier (lower) and 61.7, 175.3, and 407.5 above the barrier (upper). The two inflection points in a plot of the wetted perimeter-discharge relationship occur at 35 and 60 cfs (lower) and 28 and $50 \mathrm{cfs}$ (upper) (Figures 34 and 35). A flow of $60 \mathrm{cfs}$ is recommended for the lower reach and a flow of 50 cfs is recommended for the upper reach during the low flow period from July 1 through March 31 .

An average depth of $0.5 \mathrm{ft}$ is not reached in all transects until the flow equals or exceeds $75 \mathrm{cfs}$, (Table 20). Consequently, a flow of $75 \mathrm{cfs}$ is recommended for the period of April 1 through June 30 . 
Table 19. Results of a mark-recapture population estimate conducted in Callahan Creek (T31N, R34W, Sec. 20) during August 1986. No flow on record

\begin{tabular}{lcc}
\hline & $\begin{array}{c}\text { Total Number } \\
\text { Captured }\end{array}$ & $\begin{array}{c}\text { Estimated Number } \\
\text { Fish } \geq 75 \mathrm{~mm} \text { per km }\end{array}$ \\
Native rainbow trout & 74 & $906 \pm 551 \underline{\mathrm{a}}$ \\
Bull trout & 3 & $\underline{\mathrm{b}}$ \\
\hline a/ Low conductance of water reduced catch efficiency. \\
b/ Insufficient captures.
\end{tabular}




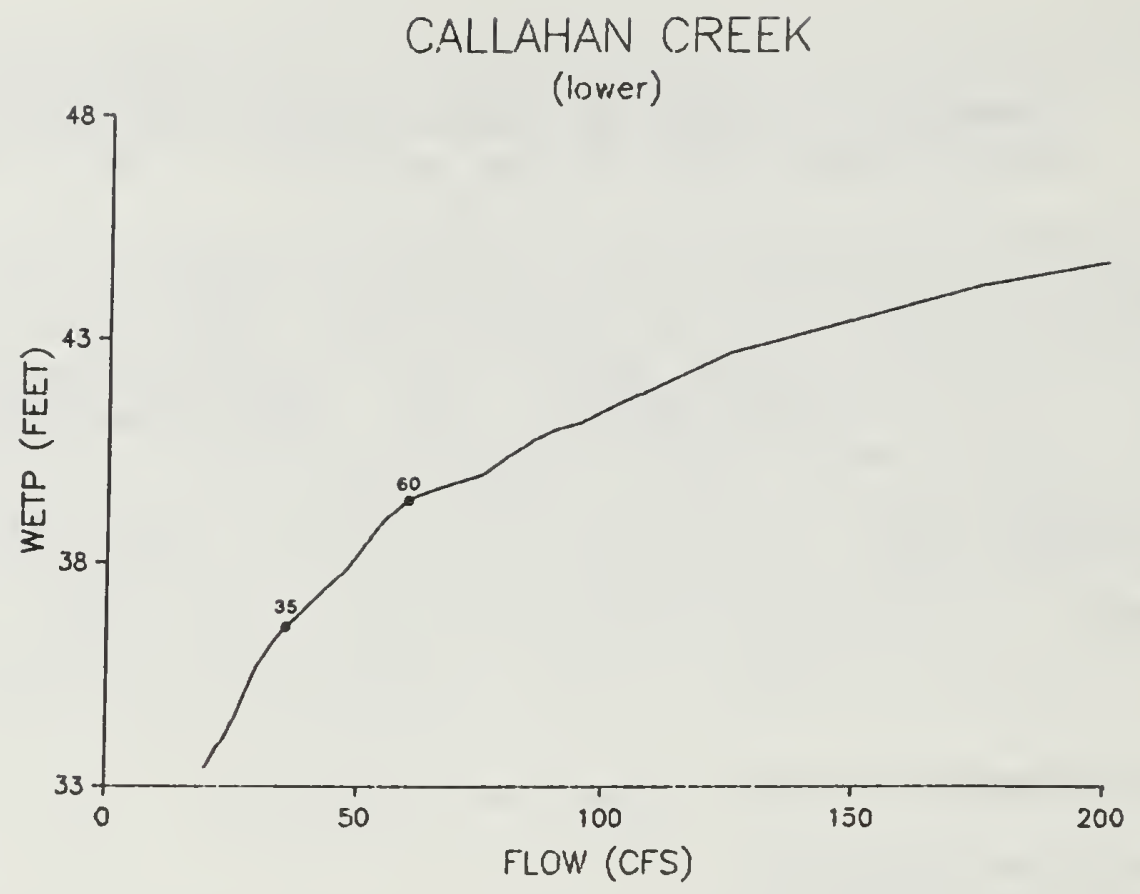

Figure 34. The wetted perimeter-discharge relationship for four riffle transects on Callahan Creek below the falls, 1985-1986

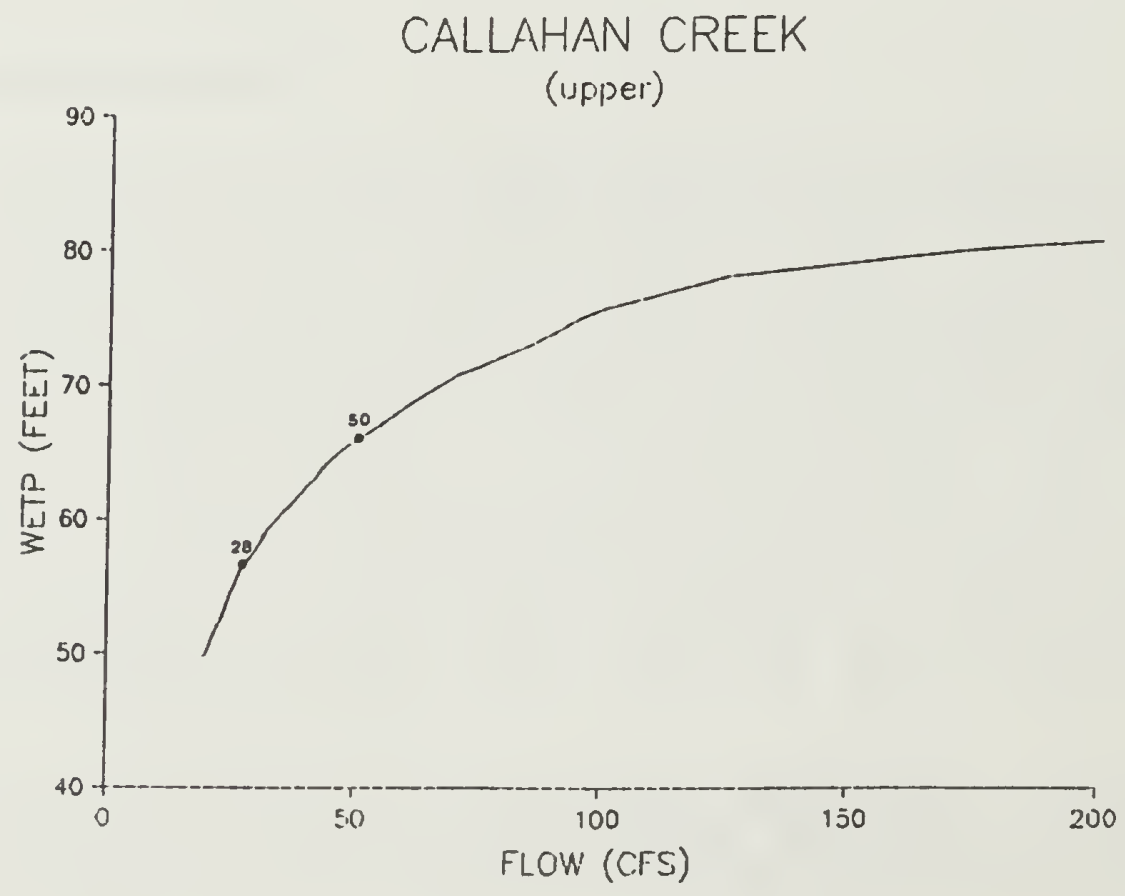

Tigure 35. The wetted perimeter-discharge relationship for four riffle transects on Callahan Creek above the falls, 1986. 
Table 20. The average depth for nine riffle cross-sections on Callahan creek at selected flows of interest.

\begin{tabular}{ccccc}
\hline $\begin{array}{c}\text { Flow } \\
\text { (cfs) }\end{array}$ & \multicolumn{4}{c}{ Average depth (ft) } \\
\cline { 2 - 5 } Lower & CS2 & CS3 & CS4 & CS5 \\
35 & .73 & .78 & .88 & .70 \\
60 & .89 & .94 & 1.01 & .86 \\
75 & .97 & 1.01 & 1.12 & .96 \\
Upper & & & .96 & CS9 \\
28 & .48 & .41 & .54 & .34 \\
50 & .65 & .56 & .57 & .41 \\
75 & .78 & .66 & .64 & .50 \\
\hline
\end{tabular}


Fisher River

\section{Description}

Stream reach: The Fisher River form its confluence with the Kootenai River (T27N, R29W, Sec. 17) upstream to Loon Lake (T27N, R28W, Sec. 27) (Figure 36).

Stream length: mouth to Wolf Creek, $18.0 \mathrm{~km}$; Wolf Creek to Loon Lake, $51.8 \mathrm{~km}$. Total length; mouth to Loon Lake, $69.8 \mathrm{~km}$. Total drainage area: $2,170.4 \mathrm{~km}^{2}$. Gradient: Wolf Creek to W. Fisher Creek, $3.9 \mathrm{~m}$ per $\mathrm{km}$.

\section{Source and Land Use}

The Fisher River begins on the west slopes of the Salish Mountains and is the largest tributary to the Montana portion of the Kootenai River drainage. Approximately 80 percent of the Fisher watershed is privately owned, mainly by Burlington Northern and Champion International; the remainder is in the Kootenai National Forest. Nearly all of the river bottom is bordered by private land. The primary land uses in the drainage include timber production and cattle ranching.

\section{Flows}

A continuous stage recording station was maintained by the U.S. Geological Survey, Water Resources Division from 1967 through 1985 (T30N, R29W, Sec. 21). Monthly mean discharges based on 18 years of daily stage measurements and associated eightieth percentile exceedence flows are summarized in Figure 37 . Mean annual discharge is 507.7 cfs.

\section{Potential Environmental Problems}

Timber production and cattle ranching have increased erosion in the watershed and destroyed much of the original riparian vegetation. Soils in the watershed are primarily unconsolidated glacio-lacustrine silts, easily eroded when the vegetation cover is depleted.

The lower reach of Fisher River from the mouth upstream to Wolf Creek was extensively channelized between 1965 and 1968 during relocation of the railroad. Construction activities denuded large areas of $l$ and and created steep slopes along the railroad grade and in channelized portions of the river. Increased sediment loading is most serious in Wolf Creek and the Fisher River downstream of the mouth of Wolf Creek. 


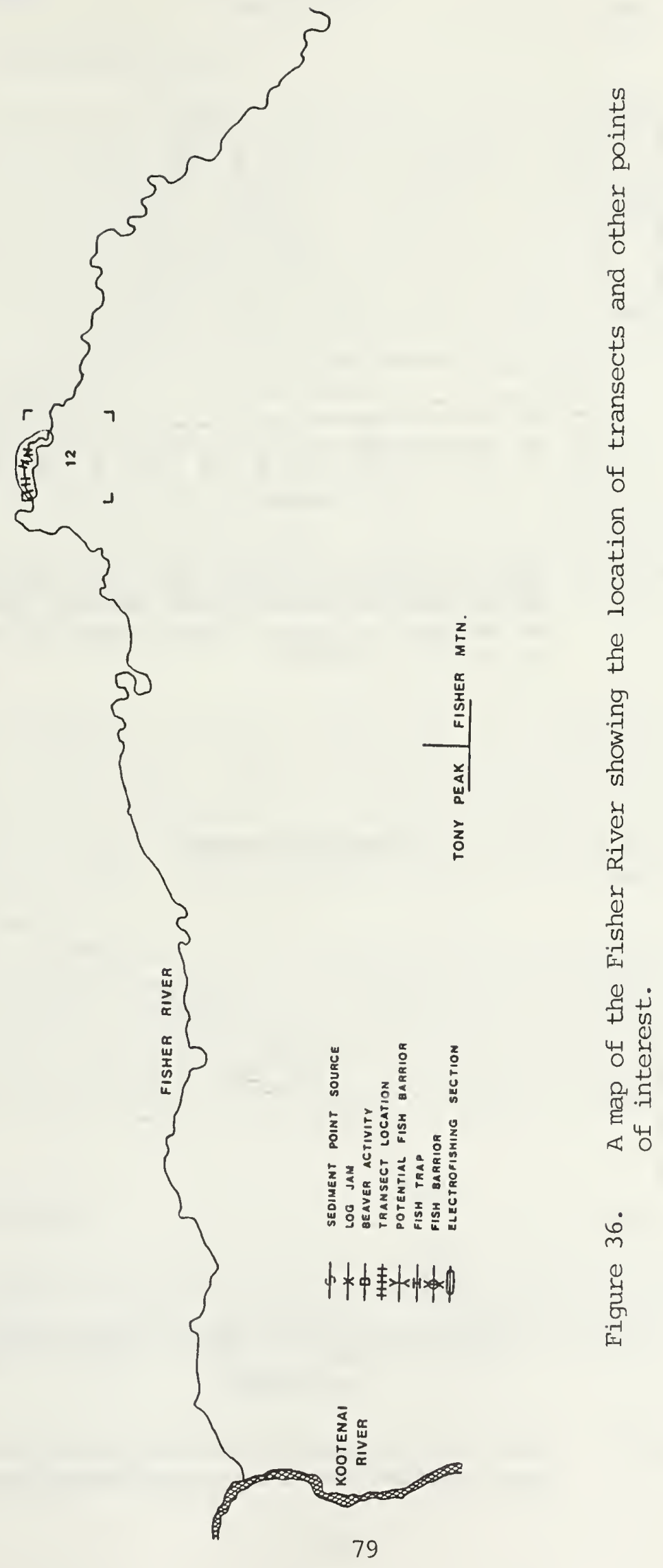




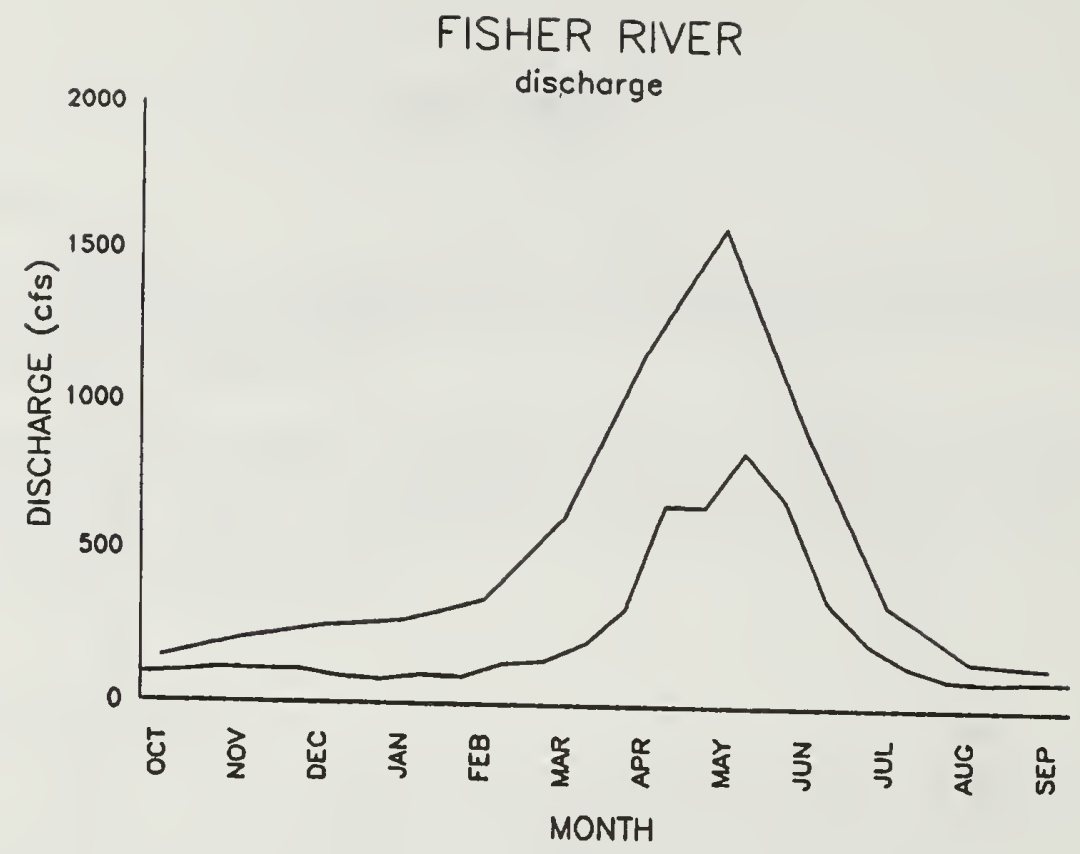

Figure 37. Mean monthly flows (top line) and eightieth percentile exceedence flows (bottom line) based on 18 years of daily stage records for the Fisher River (USGS).

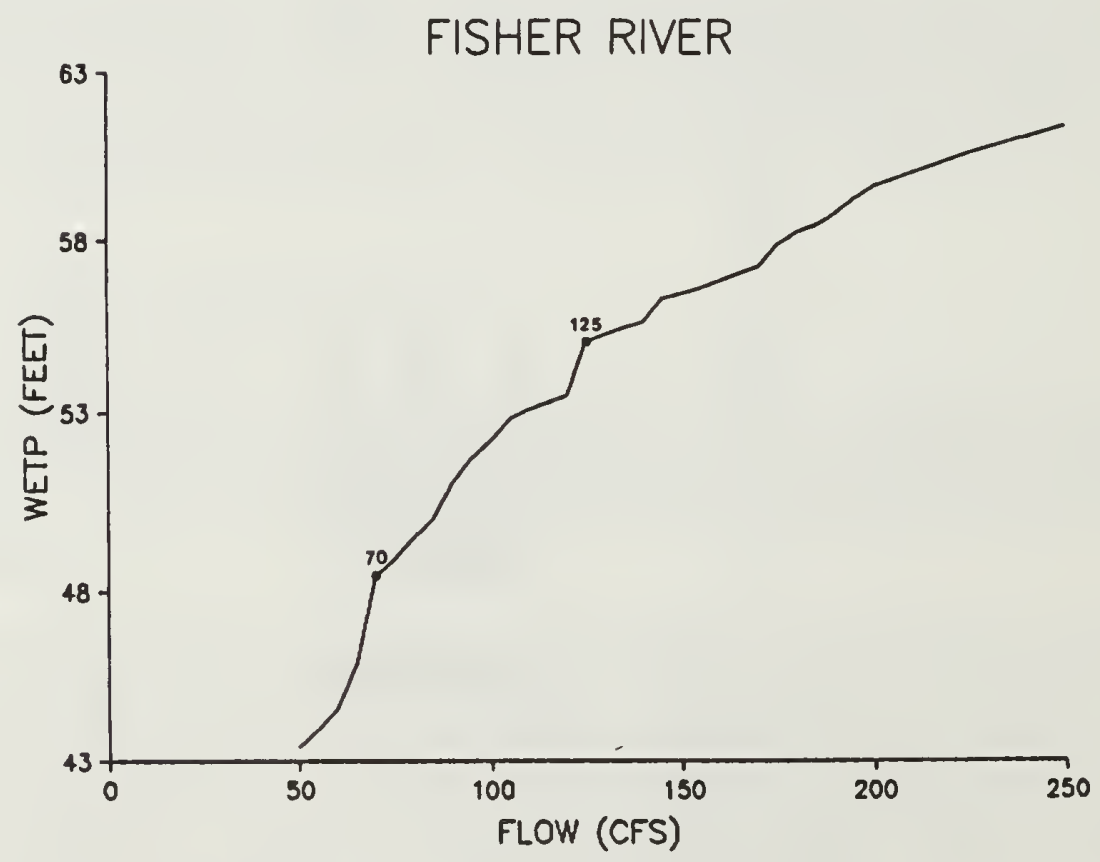

Figure 38. The wetted perimeter-discharge relationship for eight riffle transects on the Fisher River 1985-1986. 
Resident and Pre-emigrant Fish

A mark-recapture population estimate was conducted on a 4,828-m section of the Fisher River from Snell to Cow creeks, chosen for a comparison with a previous population assessment (May 1972). Mountain whitefish appeared to be the most abundant fish species in the sample areas based on snorkeling observations. A small recapture percentage reduced the reliability of an estimate and suggested that the population may have been migrating, violating the assumption of a closed population. A lengthfrequency histogram depicts modal lengths (Appendix Al6). Rainbow trout were the most numerous fish captured, followed by eastern brook trout and burbot (3) (Table 21).

The length-frequency histogram (Appendix A17) and catch efficiency curves pertaining to rainbow trout (Appendix Al8) indicate that the population is best described in three length groups: fish $>55 \mathrm{~mm}$ through $90 \mathrm{~mm}$; fish $>90 \mathrm{~mm}$ through $160 \mathrm{~mm}$; and fish $>160 \mathrm{~mm}$ through $305 \mathrm{~mm}$. It appears as though little change has occurred in the rainbow population since 1970.

\section{Migrant Fish}

Box trap sampling, conducted during the fall spawning run of 1969 and 1971 revealed that mountain whitefish run was the primary species taken, with fewer numbers of bull trout and eastern brook trout. The minimum estimate of the whitefish river was 1,131 in 1969 and 2,641 in 1970. These are the minimum number of whitefish that entered the Fisher River to spawn because trap operation was not 100 percent efficient (May 1982).

A kokanee salmon run in the Fisher River was subsampled by commercial whitefish fisherman (Gary Smith, Bear Creek Fisheries, Libby, MT, personal communications). Although catch information is incomplete due to inconsistent trapping effort, an estimated 4,000 to 5,000 kokanee were captured and released from the trap, suggesting that the Fisher River may contribute recruits to the Kootenai River and Kootenay Lake below Libby Dam.

\section{FLOW RECOMMENDATIONS}

Eight permanent transects were established on riffle areas in the Fisher River between the mouths of Snell and Cow Creeks (T28N, R29W, Sec. 12). The WETP program was calibrated to stage and discharge measurements at the following flows: 
Table 21. The results of a mark-recapture population estimate conducted on the Fisher River from Snell Creek to Cow Creek (T28N, R29W, Sec. 12) during August 1986. Discharge 73.4 cfs.

Total Number Captured

141

611

130

Total

262
Estimated Number Fish per km

Mountain Whitefish

a/

Rainbow trout

$$
\begin{aligned}
& >55-90 \mathrm{~mm} \\
& >90-160 \mathrm{~mm} \\
& >160-305 \mathrm{~mm}
\end{aligned}
$$

Rainbow trout (May 1982)

$>75 \mathrm{~mm}$ (1970)

$>75 \mathrm{~mm}$ (1971)

Eastern brook trout

$>75-205$

20

$83+34$

$219 \pm 38$

$52 \pm 20$

$354 \pm 92$

$246 \pm 153$

$525 \pm 310$

$4 \pm 1$

a/ Insufficient recaptures for estimate. 


\begin{tabular}{|c|c|c|c|c|c|c|c|c|}
\hline Transect: & CSl & CS2 & $\underline{\mathrm{CS} 3}$ & CS4 & $\underline{\mathrm{CS} 5}$ & Cs6 & CS7 & $\underline{\mathrm{CS} 8}$ \\
\hline Flows: & 155.0 & 132.2 & 132.2 & 132.2 & 132.2 & 132.2 & 155.0 & 155.0 \\
\hline \multirow[t]{4}{*}{ (cfs) } & 220.0 & 155.0 & 155.0 & 155.0 & 155.0 & 155.0 & 220.0 & 220.0 \\
\hline & 446.4 & 220.0 & 220.0 & 220.0 & 220.0 & 391.2 & 446.0 & 446.0 \\
\hline & & 391.0 & 391.0 & 391.0 & 391.0 & 446.6 & & 990.8 \\
\hline & & 446.0 & $\begin{array}{r}446.4 \\
1965.7\end{array}$ & 446.0 & 446.0 & & & \\
\hline
\end{tabular}

The lower and upper inflection points in a plot of the wetted perimeter-discharge relationship occurred at 70 and $125 \mathrm{cfs}$, respectively (Figure 38). A flow of $125 \mathrm{cfs}$ is recommended for the low flow period from July 1 through March 31 . Since the flow characteristics change substantially in the portion of the Fisher River upstream of West Fisher Creek, further research is recommended to clarify discharge requirements in west Fisher Creek, Pleasant Valley Fisher River, Silver Butte and East Fisher River.

The flow required to ensure fish passage during the spring spawning run (0.5 ft average depth) is $100 \mathrm{cfs}$ (Table 22). A flow of $100 \mathrm{cfs}$ is recommended for fish passage during the period from April 1 through July 15. Since these flows are within the recommended minimum flow during the period from July 16 through March 31, fish passage should not be a problem if recommended minimum flows are maintained (Table 23). Recommended flows amount to 48.3 percent of mean annual discharge on record.

\section{Libby Creek}

\section{Description}

Stream reach: Libby Creek from the mouth on the Kootenai River (T30N, R3lW, Sec. 2) to the headwaters (T27N, R3lW, Sec. 2l) (Figure 39).

Stream length: $42.2 \mathrm{~km}$. Total drainage area: $597.7 \mathrm{~km}^{2}$. Gradient: $14.8 \mathrm{~m}$ per $\mathrm{km}$.

\section{Source and Land Use}

Libby Creek originates on the east slope of the Cabinet Mountains and flows north, northeast to the Kootenai River. Approximately 82 percent of the Libby Creek watershed is in the Kootenai National Forest, with the remainder in private and state ownership. Source headwaters drain portions of the Cabinet Mountain Wilderness. Timber production is the primary land use in the drainage. The lower section of creek bottom is subdivided into 1-10 acre plots. The area of Libby Creek from the mouth upstream for $1.6 \mathrm{~km}$ flows adjacent to a Champion International Lumber Mill. 
Table 22. The average depth for eight riffle cross-sections in Fisher River at selected flows of interest.

\begin{tabular}{rrrrrrrrrr}
\hline \multirow{2}{*}{$\begin{array}{c}\text { Flow } \\
\text { (cfs) }\end{array}$} & CS1 & CS2 & CS3 & CS4 & CS5 & CS6 & CS7 & CS8 \\
\hline \multirow{2}{*nnnyyyyyy}{70} & 1.13 & .95 & 1.50 & 1.11 & 1.45 & .90 & .98 & .43 \\
100 & .78 & 1.09 & 1.61 & 1.26 & 1.46 & 1.05 & 1.10 & .50 \\
125 & .80 & 1.20 & 1.70 & 1.36 & 1.60 & .99 & 1.13 & .59 \\
\hline
\end{tabular}


Table 23. Recommended minimum flows for the Fisher River and historical water availability records based on 18 years of daily records (USGS).

\begin{tabular}{|c|c|c|c|c|}
\hline $\begin{array}{r}\text { Period of } \\
\text { Water Year }\end{array}$ & $\begin{array}{c}\text { Recommended } \\
\text { Flows }\end{array}$ & $\begin{array}{l}\text { 80\% Exceedence } \\
\text { Flows } \\
\end{array}$ & $\begin{array}{l}\text { Mean } \\
\text { Flows } \\
\end{array}$ & $\begin{array}{l}\text { Acre } \\
\text { Feet }\end{array}$ \\
\hline $1-\infty \mathrm{OT} 15$ & 125.0 & 89.4 & 141.2 & 4200.0 \\
\hline ОCT 16 - ОCT 31 & 125.0 & 96.0 & 141.2 & 4480.0 \\
\hline NOV 1 - NOV 15 & 125.0 & 106.4 & 201.7 & 5999.6 \\
\hline NOV 16 - NOV 30 & 125.0 & 105.0 & 201.7 & 5999.6 \\
\hline $\mathrm{DEC} 1-\mathrm{DEC} 15$ & 125.0 & 105.1 & 244.3 & 7266.7 \\
\hline DEC 16 - DEC 31 & 125.0 & 84.7 & 244.3 & 7751.2 \\
\hline JAN 1 - JAN 15 & 125.0 & 78.9 & 264.9 & 7879.5 \\
\hline JAN 16 - JAN 31 & 125.0 & 92.4 & 264.9 & 8404.7 \\
\hline FEB 1 - FEB 15 & 125.0 & 87.3 & 336.3 & 10003.2 \\
\hline FEB 16 - FEB 28 & 125.0 & 129.5 & 336.3 & 8002.6 \\
\hline MAR 1 - MAR 15 & 138.0 & 137.8 & 619.8 & 18436.0 \\
\hline MAR 16 - MAR 31 & 195.0 & 195.3 & 619.8 & 19665.0 \\
\hline APR 1 - APR 15 & 312.0 & 312.3 & 1163.4 & 34605.3 \\
\hline APR 16 - APR 30 & 659.0 & 659.2 & 1163.4 & 34605.3 \\
\hline MAY 1 - MAY 15 & 657.0 & 657.0 & 1587.0 & 47205.3 \\
\hline MAY 16 - MAY 31 & $842.0^{\mathrm{a}}$ & 841.9 & 1587.0 & 50352.3 \\
\hline JUN 1 - JUN 15 & 678.0 & 678.2 & 919.2 & 27341.6 \\
\hline JUN 16 - JUN 30 & 324.0 & 342.3 & 919.2 & 27341.6 \\
\hline JUL 1 - JUL 15 & 207.0 & 207.1 & 330.8 & 9839.6 \\
\hline JUL 16 - JUL 31 & 125.0 & 133.0 & 330.8 & 10495.6 \\
\hline AUG 1 - AUG 15 & 125.0 & 96.4 & 150.7 & 4482.6 \\
\hline AUG 16 - AUG 31 & 125.0 & 87.9 & 150.7 & 4781.4 \\
\hline SEP 1 - SEP 15 & 125.0 & 92.2 & 133.3 & 3965.0 \\
\hline SEP 16 - SEP 30 & 125.0 & 93.1 & 133.3 & 3965.0 \\
\hline
\end{tabular}

a/ A dominant discharge flow (approximated bankful flow presently undefined) should be maintained for 24 hours during this period. 


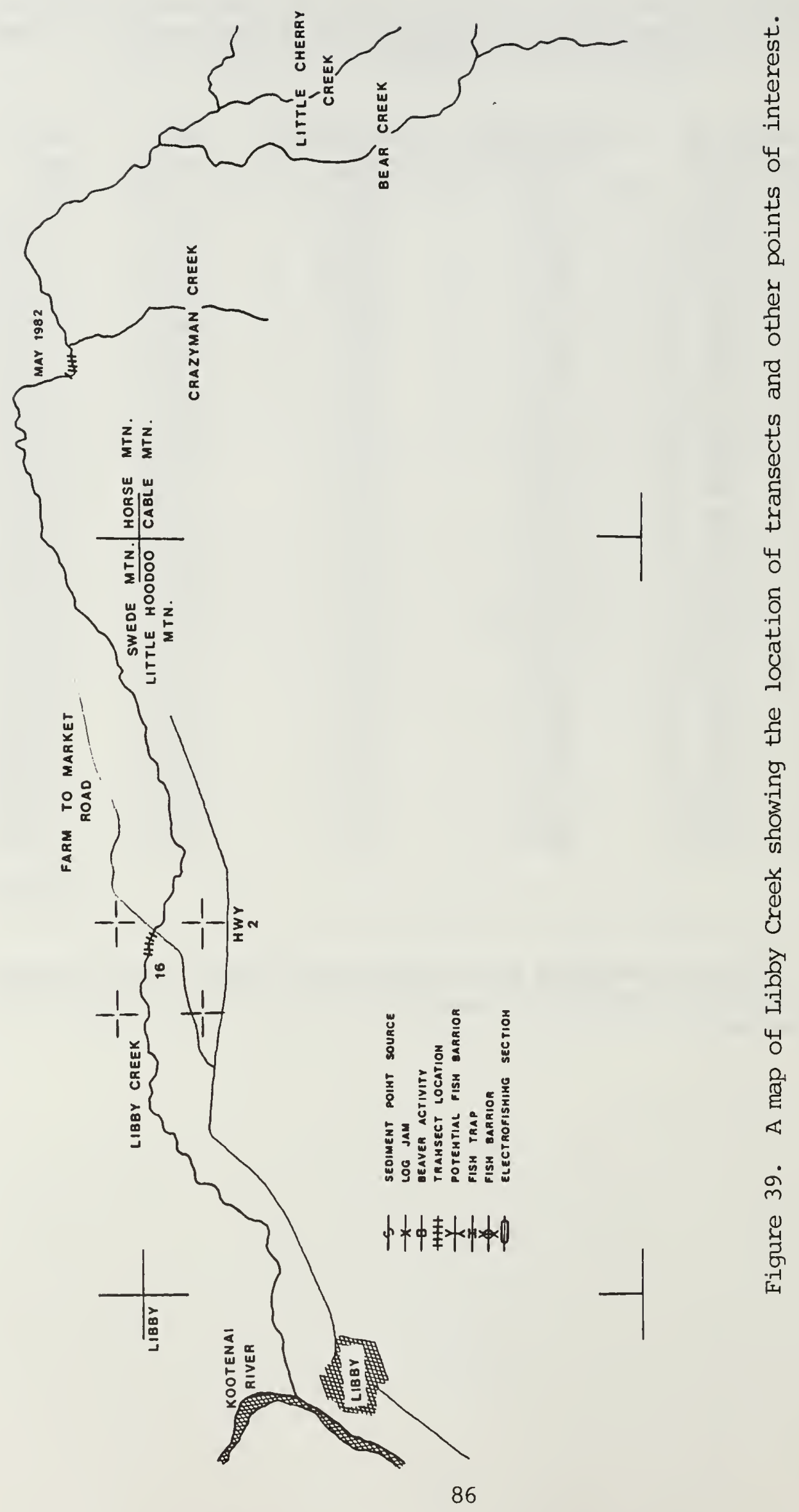


Little flow information exists for Libby Creek except for miscellaneous measurements taken by the U.S. Geological Survey and by personnel of the Kootenai National Forest. Estimated mean annual discharge is 157.2 cfs. A wetted perimeter analysis was performed by the Montana Department of Fish, Wildlife and Parks approximately $21 \mathrm{~km}$ upstream from its confluence with the Kootenai River (T28N, R30W, Sec. 5) (May 1982).

\section{Potential Environmental Problems}

Total water appropriations listed for Libby Creek amount to $124.3 \mathrm{cfs}$ not including some allotments for livestock which are based on stock type and herd size. If all water users exercise their water rights to the fullest extent possible, the stream would be dewatered for most of the water year. It is not known, however, what percentage of existing claims are valid or presently in use.

Timber production, road building and the removal of vegetation from the floodplain for pasture and housing developments have increased peak flows resulting in severe channel instability and sediment loading to the drainage system.

Pollution from an abandoned mine and mill on Snowshoe Creek is limiting fish production on Snowshoe and Big Cherry Creeks, tributaries to Libby Creek (May 1982).

\section{FISH POPULATIONS}

\section{$\underline{\text { Resident and Pre-emigrant Fish }}$}

A mark-recapture population survey was conducted on a 1,981.2-m section of Libby Creek from the Farm to Market Road bridge downstream to the Champion Hawl Road bridge. The location was selected for comparison with a similarly placed population assessment completed in 1977 (May 1982). Gamefish were composed primarily of rainbow trout and relatively fewer numbers of eastern brook trout and mountain whitefish (Table 24). Based on the length-frequency histogram (Appendix A19) and catch efficiency curves pertaining to rainbow trout in Libby Creek (Appendix A20), the population is best described in two groups:

\section{and Fish $>155 \mathrm{~mm}$ through $345 \mathrm{~mm}$ TL.}

Results indicate a substantial decline in rainbow trout since 1977. Length-frequency histograms describe modal lengths of eastern brook trout (Appendix A21). 
Table 24. Results of a mark-recapture population estimate conducted in Libby Creek (T30N, R31W, Sec. 36) during July 1986. Discharge 27.7 cfs.

\begin{tabular}{|c|c|c|}
\hline $\begin{array}{l}\text { Length } \\
\text { Category }\end{array}$ & $\begin{array}{l}\text { Total Number } \\
\text { Captured }\end{array}$ & $\begin{array}{l}\text { Estimated Number } \\
\text { Fish } \geq 75 \mathrm{~mm} \text { per } \mathrm{km}\end{array}$ \\
\hline Rainbow trout (1986) & & \\
\hline $\begin{array}{l}>75-155 \mathrm{~mm} \\
>155-345 \mathrm{~mm}\end{array}$ & $\begin{array}{r}251 \\
49\end{array}$ & $\begin{array}{r}236 \pm 66 \\
30 \pm 13\end{array}$ \\
\hline Total & & $266 \pm 79$ \\
\hline Rainbow trout (1977) & & $850 \pm 161 \mathrm{~b} /$ \\
\hline$\frac{\text { Eastern brook trout }}{>75-210 \mathrm{~mm}}$ & 38 & $25 \pm 11$ \\
\hline Mountain whitefish & & \\
\hline$>70-360 \mathrm{~mm}$ & 12 & a/ \\
\hline
\end{tabular}

a) Capture insufficient for estimate.

b/ Based on $(P \geq 0.80)$ (May 1982). 
Based on sporadic fish trapping data during the spring spawning runs of 1976, 1977 and 1981, May (1982) stated that "Libby Creek probably supports a run of 400-1,000 rainbow trout and is the most important spawning and nursery tributary downstream from Libby Dam." Average length of males captured during the three trapping efforts were $408.9 \mathrm{~mm}, 411.5 \mathrm{~mm}$ and $368.3 \mathrm{~mm}$, whereas females were larger averaging $472.4 \mathrm{~mm}, 485.1 \mathrm{~mm}$, and $393.7 \mathrm{~mm}$ during 1976, 1977 and 1981 respectively.

A run of kokanee salmon was passed upstream through a trap structure near the mouth of Libby Creek by a commercial whitefish fisherman (Gary Smith, personal communications). Although catch information is incomplete due to inconsistent trapping effort, an estimated 100 kokanee entered Libby Creek to spawn, suggesting that Libby Creek and its tributaries may contribute recruits to the Kootenai River and Kootenay Lake below Libby Dam.

\section{FLOW RECOMMENDATIONS}

Five permanent transects were installed across riffle areas in Libby Creek (T30N, R31W, Sec. 36). The WETP program was calibrated to stage and discharge measurements at flows of 31.8 , 82.2 and $209.6 \mathrm{cfs}$. The lower and upper inflection points in a plot of the wetted perimeter-discharge relationship occur at flows of 9.0 and $22.5 \mathrm{cfs}$, respectively (Figure 40 ). Based on existing fish populations, the wetted perimeter analysis and estimated water availability, a flow of $22 \mathrm{cfs}$ is recommended for the low flow period from July 16 through March 31.

An average depth of $0.5 \mathrm{ft}$, required for migrant fish passage, is not met until flows equal or exceed 37.5 cfs (Table 25). A flow of $38.0 \mathrm{cfs}$ is recommended for the period from April 1 through July 15 in ensure a successful spawning run and to protect spawning redds from dewatering.

Based on a reanalysis of data compiled on Libby Creek by May (1982) at a station approximately $21 \mathrm{~km}$ upstream from its confluence with the Kootenai River, inflection points occurred at 12 and 45 cfs (Figure 41). A flow of $15 \mathrm{cfs}$ is recommended for Libby Creek upstream of T28N, R30W, Sec. 5 to Bear Creek during the period from July 16 through March 31.

A depth of $0.5 \mathrm{ft}$ is not reached at all transects until flows equal or exceed $35 \mathrm{cfs}$ (Table 26). A fish passage flow of $35 \mathrm{cfs}$ is recommended for the period from April 1 through July 15. 


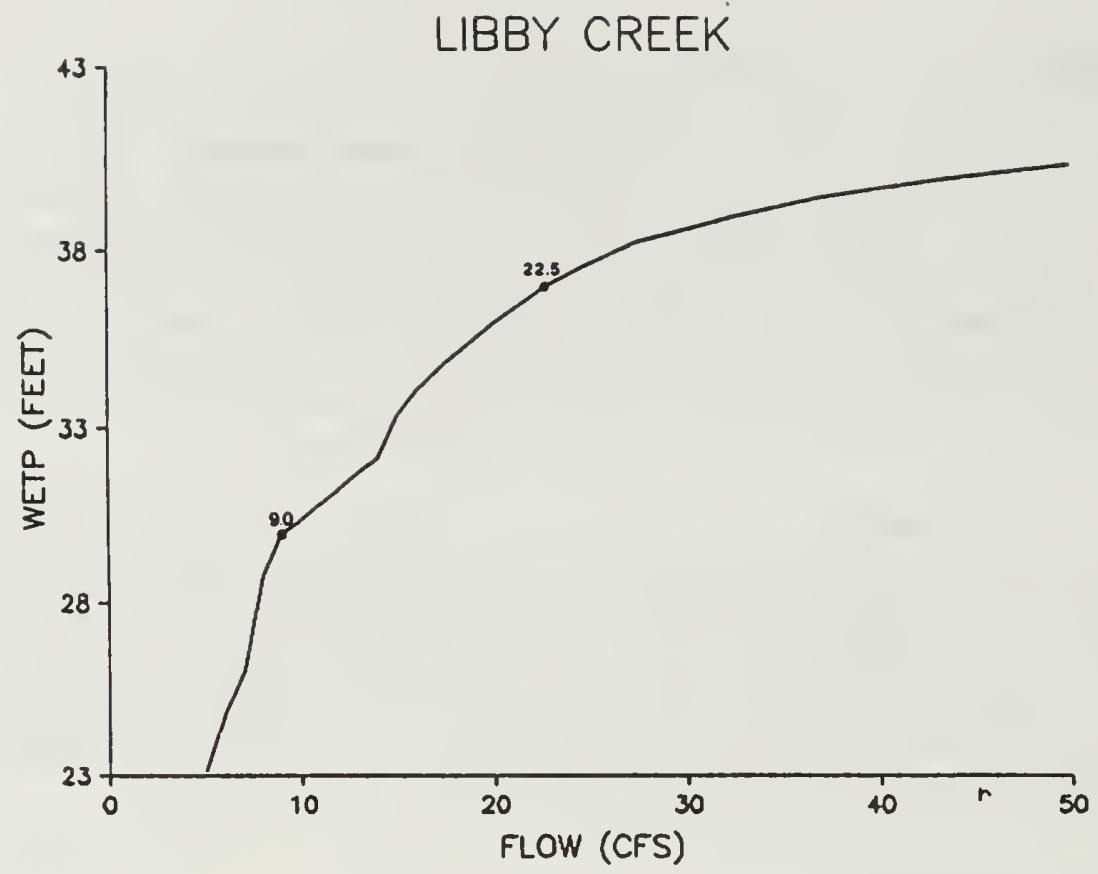

Figure 40. The wetted perimeter-discharge relationship for five riffle transects on Libby Creek 1985-1986.

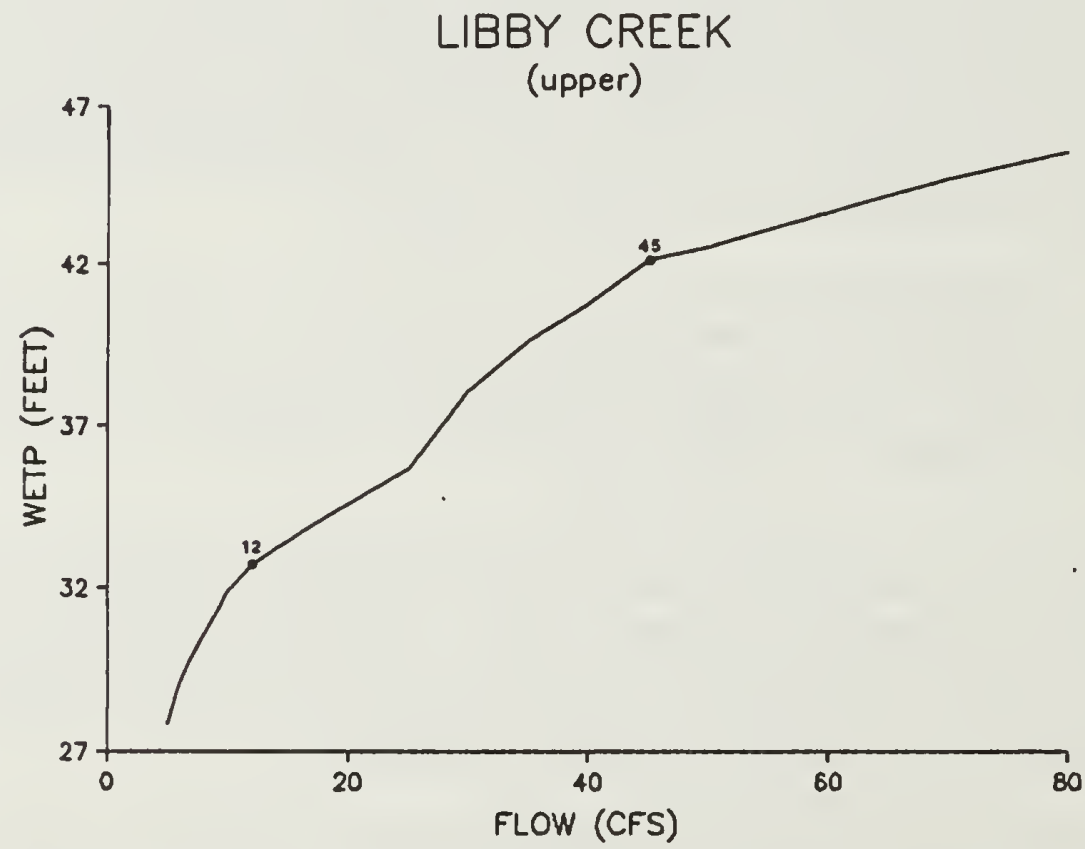

Figure 41. The wetted perimeter-discharge relationship for five riffle transects on Libby Creek (May 1982). 
Table 25. The average depth for five riffle cross-sections in Libby Creek at selected flows of interest.

\begin{tabular}{lccccc}
\hline \multirow{2}{*}{$\begin{array}{c}\text { Flow } \\
\text { (cfs) }\end{array}$} & \multicolumn{6}{c}{ Average depth } & (ft) \\
\cline { 2 - 6 } 9.0 & .36 & .29 & .31 & .29 & .32 \\
22.5 & .57 & .37 & .53 & .53 & .51 \\
37.5 & .69 & .50 & .69 & .70 & .67 \\
\hline
\end{tabular}


Table 26. The average depth for four riffle cross-sections in upper Libby Creek at selected flows of interest.

\begin{tabular}{|c|c|c|c|c|}
\hline \multirow[b]{2}{*}{$\begin{array}{l}\text { Flow } \\
\text { (cfs) }\end{array}$} & \multicolumn{4}{|c|}{ Average depth (ft) } \\
\hline & $\overline{\mathrm{CSl}}$ & CS2 & CS3 & $\overline{C S 4}$ \\
\hline 12 & .75 & .37 & .41 & .42 \\
\hline 35 & 1.16 & .55 & .50 & .66 \\
\hline 45 & 1.23 & .61 & .50 & .76 \\
\hline
\end{tabular}




\section{Quartz Creek}

\section{Description}

Stream reach: Quartz Creek from the mouth on the Kootenai River (T31N, R32W, Sec. 24) upstream to Hennesy Creek (T32N, R32W, Sec. 11) (Figure 42).

Stream length: $14.7 \mathrm{~km}$. Total drainage area: $93.1 \mathrm{~km}^{2}$. Gradient: $30.8 \mathrm{~m}$ per $\mathrm{km}$.

\section{Source and Land Use}

Quartz Creek originates in Ransom Creek on the southern slopes of the Purcell Mountains and flows south for $16.3 \mathrm{~km}$ to the Kootenai River. Approximately 3.3 percent of the drainage is privately owned, much of which belongs to Champion International and Burlington Northern. The remainder of the watershed is in the Kootenai National Forest. Timber production is the major land use in the basin.

\section{Flows}

Little flow information exists for Quartz Creek other than sporadic measurements from a stage-discharge station maintained by the U.S. Geological Survey, Water Resources Division (T31N, R32W, Sec. 24), and miscellaneous data compiled by personnel of the Kootenai National Forest. An annual hydrograph was constructed based on best available information (Figure 43). Estimated mean annual discharge is $33.9 \mathrm{cfs}$.

\section{Potential Environmental Problems}

Timber harvest may increase sediment loading and alter peak flows resulting in channel stability problems and damage to fish habitat.

\section{FISH POPULATIONS}

\section{Resident and Pre-emigrant Fish}

A mark-recapture population estimate was conducted in a 152.4-m blocknetted section of stream approximately $1 \mathrm{~km}$ above the mouth on the Kootenai River. Game fish were primarily Salmo spp., and relatively fewer numbers of bull trout (5) and mountain whitefish (1) (Table 27). Based on a length-frequency histogram 


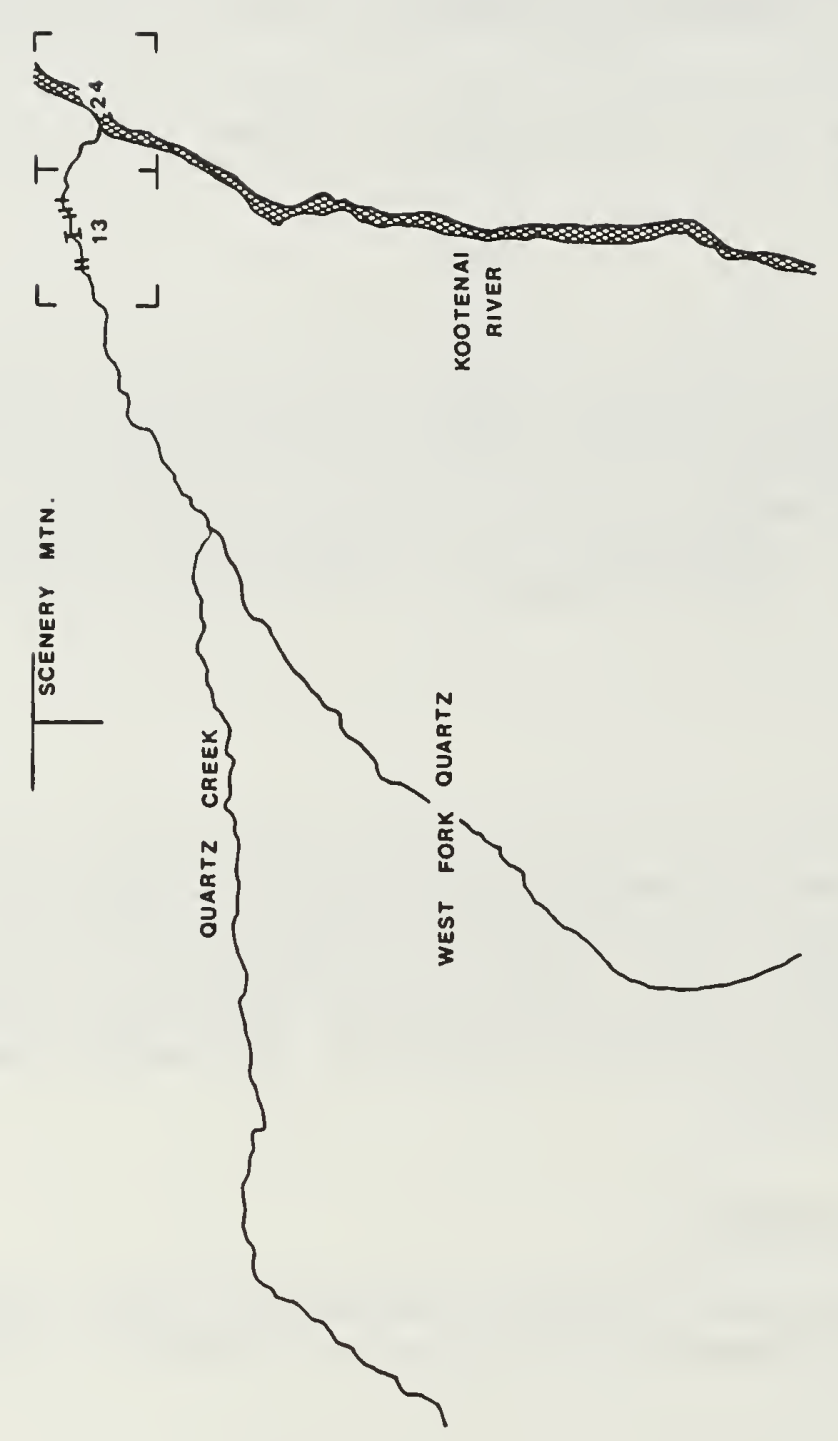

낭

.

离

뭄

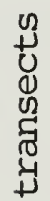

茨

.

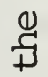

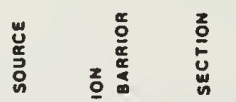

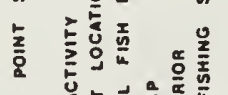

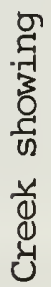

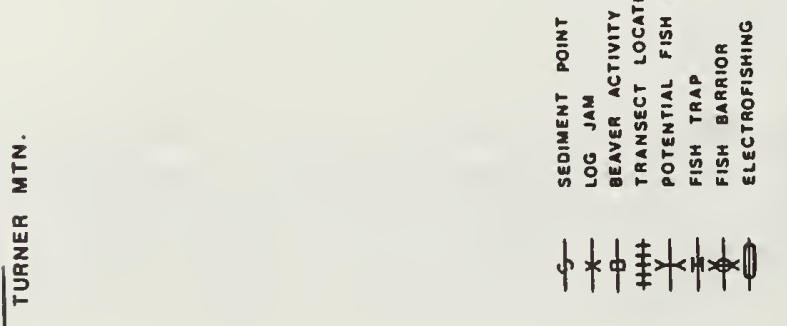

ชั

矛 


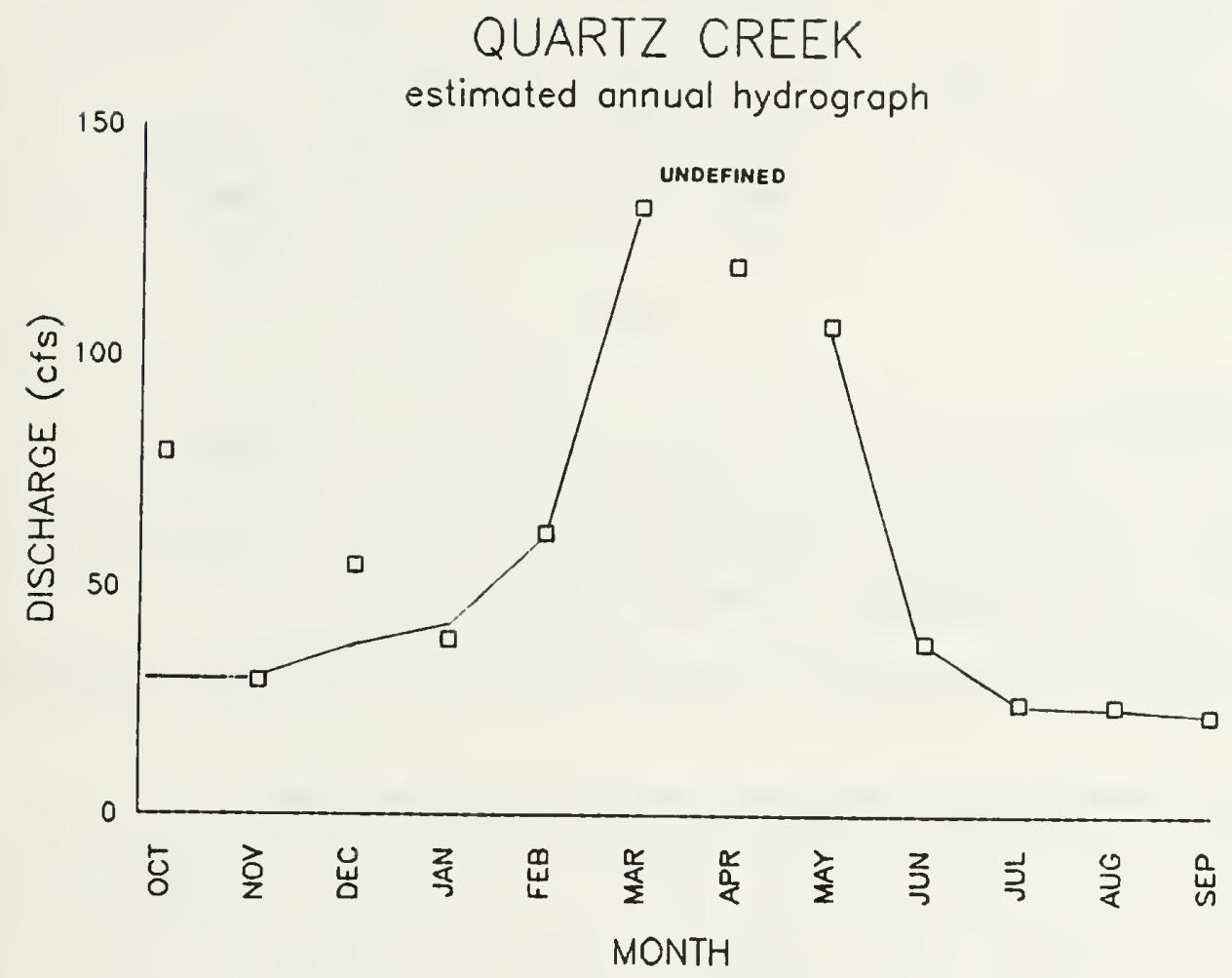

Figure 43. An estimated hydrograph for Quartz Creek based on a comparison of seven concurrent flow measurements made at the Fisher River USGS stage-discharge gauging station and 117 miscellaneous measurements. 
Table 27. Results of a mark-recapture population estimate conducted on lower Quartz Creek (T31N, R32W, Sec. 13) during September 1985. No flow on record

Length

Category
Total Number Captured
Estimated Number Fish $\geq 75 \mathrm{~mm}$ per $\mathrm{km}$ \begin{tabular}{l} 
Salmo spp \\
\hline $45-75 \mathrm{~mm}$ \\
$>75-135 \mathrm{~mm}$ \\
$>135-295 \mathrm{~mm}$
\end{tabular}

$\frac{165-220 \mathrm{~mm}}{>165}$
67
54
33

$\begin{array}{rl}1,772 \pm 1371 \underline{\mathrm{b}} & 709 \pm 400 \\ 144 \pm 38 \\ \text { TOTAL }(\geq 75 \mathrm{~mm}) & 853 \pm 438\end{array}$

a) Species composition: $\mathrm{RB}=94.9 \%, \mathrm{WCT}=4.3 \%$, $\mathrm{HYB}=0.8 \%$

b/ Length category subject to high variance in estimate of this type.

c/ May be migrating recruits, estimate questionable. 
(Appendix A27) and a catch efficiency curve (Appendix A23) the Salmo spp. population is best described in three length groups:

\author{
Fish $>45 \mathrm{~mm}$ through $75 \mathrm{~mm}$ \\ Fish $>75 \mathrm{~mm}$ through $135 \mathrm{~mm}$ \\ and Fish $>135 \mathrm{~mm}$ through $295 \mathrm{~mm}$ Td
}

A two-pass population estimate was conducted on a 182.8 meter blocknetted section of Quartz Creek upstream of West Fork Quartz Creek. Game fish were primarily Salmo spp., and relatively fewer numbers of bull trout and eastern brook trout (Table 28). A length-frequency histogram presents modal lengths of Salmo spp (Appendix A24).

\title{
Miqrant Fish
}

A bi-directional trap structure was installed approximately 1 $\mathrm{km}$ above the mouth in Quartz Creek (T31N, R32W, Sec. 13) to capture migrants moving both upstream and downstream. The upstream migrant trap was monitored singularly from April 7, 1986 through April 14, 1986 when the downstream migrant trap became functional. The traps continued to be monitored through September, 1986. The following discussion pertains to captures prior to August 31, 1986.

The first capture of upstream migrants occurred on April 8, indicating that the spawning run had already begun. The next capture, however, took place on April 19 and catches were sparse but consistent thereafter until mid May when captures became more frequent. The first fish sampled were males, 50 percent of which were unripe, suggesting that the run was at its onset. It is therefore assumed that few fish migrated beyond the trap side prior to installation of the trap.

A total of 96 Salmo spp. $\geq 180 \mathrm{~mm}$ were captured migrating into Quartz Creek, whereas only 32 fish returned to the trap site.

The maximum likelihood estimate of the total migrant population, estimated using Schnable's Multiple Census Formula (Ricker 1975), amounted to $280 \mathrm{fish}$, with a range of 177 to 444 ( $p \geq 0.95$, Poisson). Species composition was $\mathrm{RB}=90.8 \%$, $\mathrm{WCT}=1.5 \%$, and HYB $=7.68$.

Length-frequency histogram for upstream and downstream migrants are similar in modal lengths indicating that the assumption of a closed population was not violated by recruitment of a different size category from within the creek (Figure 44). 
Table 28. Results of a two-pass population estimate conducted on upper Quartz Creek (T32N, R32W, Sec. 35) during July, 1986. Discharge 8.2 cfs.

\begin{tabular}{ccc} 
Length & Total Number & Estimated Number \\
Category & Captured & Fish $>75 \mathrm{~mm}$ per km \\
\hline
\end{tabular}

Salmo spp. a/

39

$224 \pm 22$

Bull trout

23

$142 \pm 27$

Eastern brook trout

14

b/

a) Species composition: $\mathrm{RB}=10.38, \mathrm{WCT}=84.68, \mathrm{HYB}=5.18$.

b/ $\hat{p}=$ undefined, insufficient for estimate. 


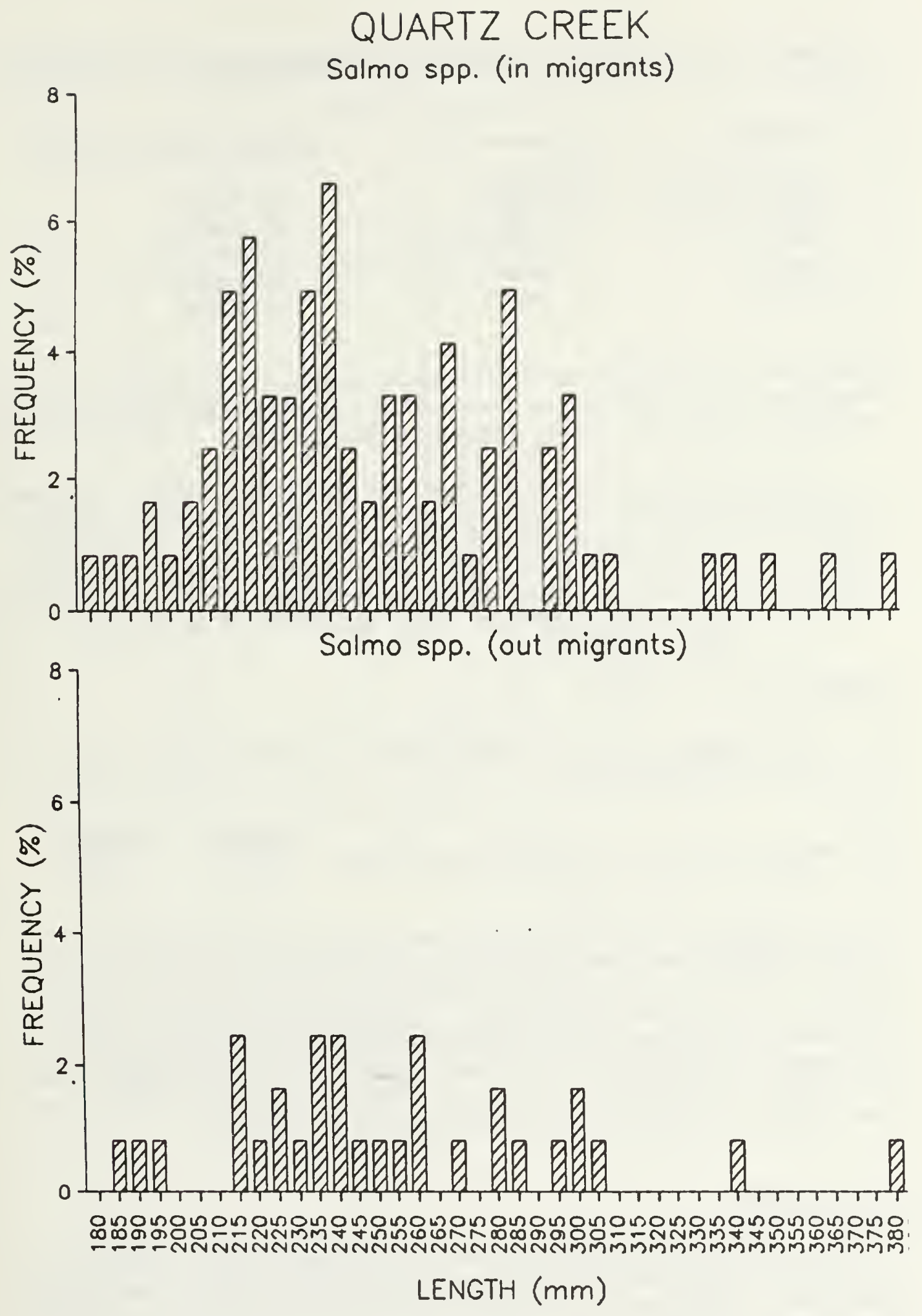

Figure 44. Length-frequency histograms of Salmo spp. captured while migrating into (top) and out of guartz Creek (bottom) during the spring spawning run, 1986. 
dates:

Both trap leads were breached simultaneously on the following

Date

April 10

April 23

May 20

May 27

May 28
Estimated Time

24 hours

30 hours

8 hours

8 hours

8 hours
Maximum Possible Time

36 hours

36 hours

18 hours

12 hours

12 hours

Bias due to fish passing undetected through the trap system was considered negligible since unmarked and marked fish $\geq 180 \mathrm{~mm}$ were assumed to have had random chances of escapement.

The timing of the spawning run was protracted extending from approximately April 8 through June 26 (Figure 45). Tagged migrants remained in the creek for an average of 19 days with a range of 7 to 33 days at large. Catches were standardized as In(catch per day +1 ), assuming catch rate was constant. Water temperature range and discharge (cfs) are overlaid on the plot.

\section{Redd Survey}

Redds (Salmo spp.) observed by field personnel were placed in the following categories:

$\begin{array}{lcc}\text { Trap site to } 1.6 \mathrm{~km} \text { above Hennesy Creek } & \frac{\text { Definite }}{96} & \frac{\text { Probable }}{82} \\ \text { Total west fork } & 12 & 6\end{array}$

A comparison of estimated spawners (utilizing that portion of Quartz Creek above the trap site) to the number of redds classified as definite and probable, produced an estimate of approximately 1.4 fish per redd with a range of 0.9 to 2.3. The low estimate of fish per redd probably reflects the large population of resident Salmo spp. which create redds indistinguishable from those made by some migrant trout. The sex ratio of individual fish captured in the trap was 1.6:1 males to females.

\section{Fry Emergence}

Fry emergence traps described by Fraley et al. (1986) were placed on five randomly-selected, positively-identified Salmo redds and monitored during the period from June 12 through September 2, 1986. Fry were enumerated and released from the holding bottle (Table 29). 


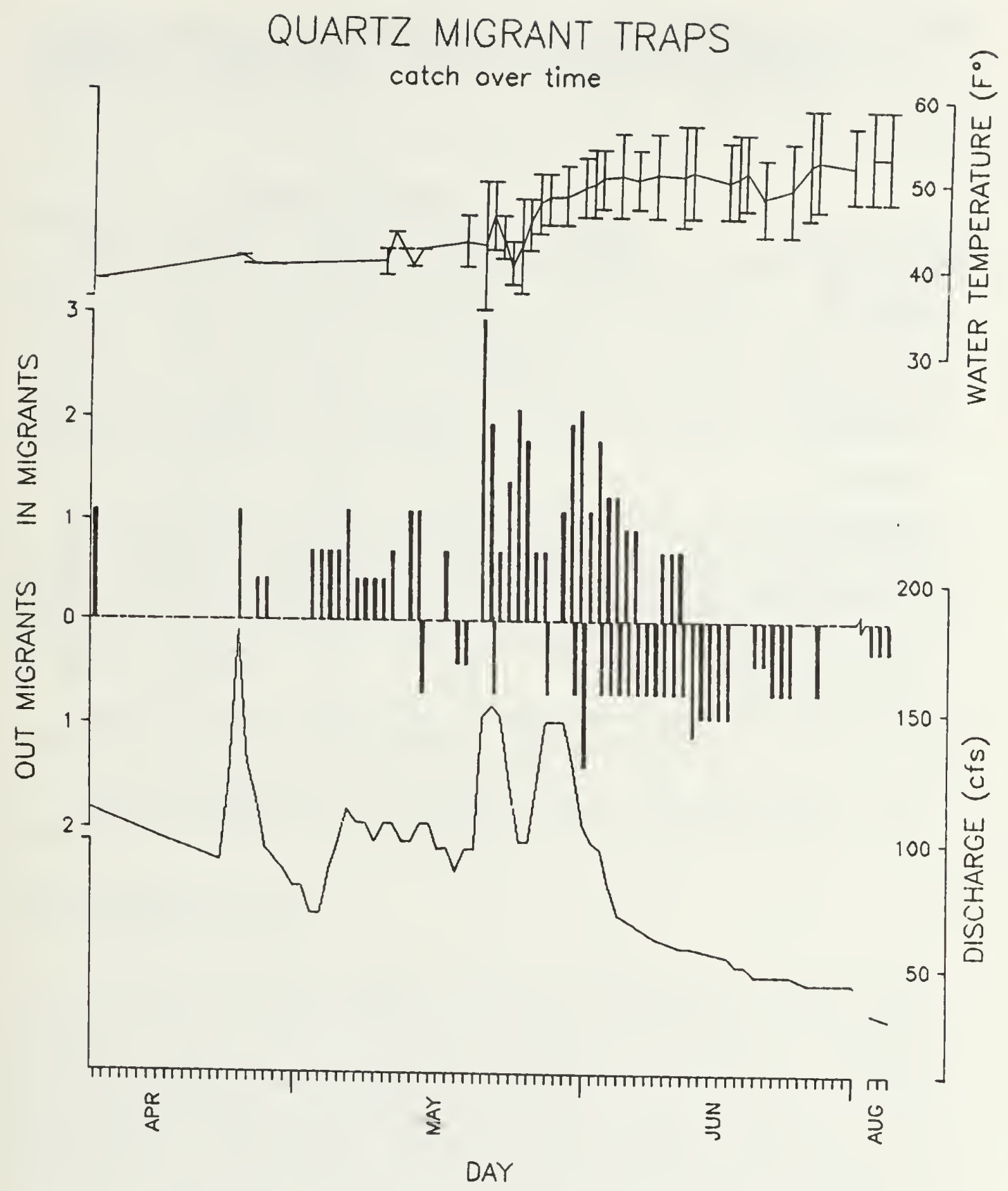

Figure 45. Catch direction and distribution over time of migrating Salmo spp. captured during spring 1986, and associated water temperatures and stream discharge.

(Note: logorithmic scale) 
Table 29. Captures of Salmo fry in emergence traps set in Quartz Creek (T32N, R32W, Sec. 35) from June 12 through September 2, 1986.

\section{Number Captured}

Date of Sample

July 28

August 2

August 4

August 6

August 11

August 14

TOTAL FOR REDD

Redd 1 Redd 2 Redd 3

11

3

5

0

0

12

2

7

0

3

2

1

37

5

0

0

0

0

0

0

0

$\overline{15}$

$\overline{6}$

$\overline{54}$

$\overline{0}$ 
Fry emergence averaged 19.2 fry per redd in 5 randomly selected spawning sites. Based on the total number of positive and probable redds (196), fry recruited to Quartz creek were estimated at 3,763 young.

\section{Bull Trout Migrants}

A total of 24 adults were captured entering Quartz Creek to spawn. The first two adults were caught on May 31, 1986; the remainder were sampled between July 9 and September 25. These migrants apparently escaped recapture on their downstream migration. Leaves and ice clogged the trap leads causing decreased trapping efficiency, precluding the possibility of a statistical population estimate. Captures ranged in length from 316 to $765 \mathrm{~mm}$ (TL) (Appendix A25).

A downstream migration of bull trout recruits began on April 21 and ended on September 19 as indicated by trap captures. Peak catches occurred during June. Eighteen individuals $\geq 180 \mathrm{~mm}$ were captured, other recruits captured were not representative of the total run because smaller individuals could pass through the mesh of the trap leads.

Smaller meshed leads will be used for future sampling during the time of bull trout emigration from the stream.

Results indicated that Quartz Creek is a major bull trout production tributary for the Kootenai River above Kootenai Falls.

\section{FLOW RECOMMENDATIONS}

Five transects were permanently established across riffle areas in Quartz Creek approximately $1 \mathrm{~km}$ above the mouth (T3lN, R32 $N$, Sec. 13). the WETP program was calibrated to stage and discharge measurements at flows of 16.3, 51.3, 103.6, and 132.0. The lower and upper inflection points in a plot of the wetted perimeter-discharge relationship occurred at 7.0 and $17.5 \mathrm{cfs}$, respectively (Figure 46). Based on the existing fish population, the wetted perimeter analysis and estimated water availability, a minimum discharge of $17.5 \mathrm{cfs}$ is recommended for the low flow period from August 1 through April 15

An average depth of $0.5 \mathrm{ft}$, required for successful passage of migrant spawners, is not met in all riffle transects until discharge equals or exceeds 25 cfs (Table 30 ). A fish passage flow of $25 \mathrm{cfs}$ is therefore recommended for the period of April 16 through July 31 to assume a successful spawning migration and to protect spawning redds from dewatering. 


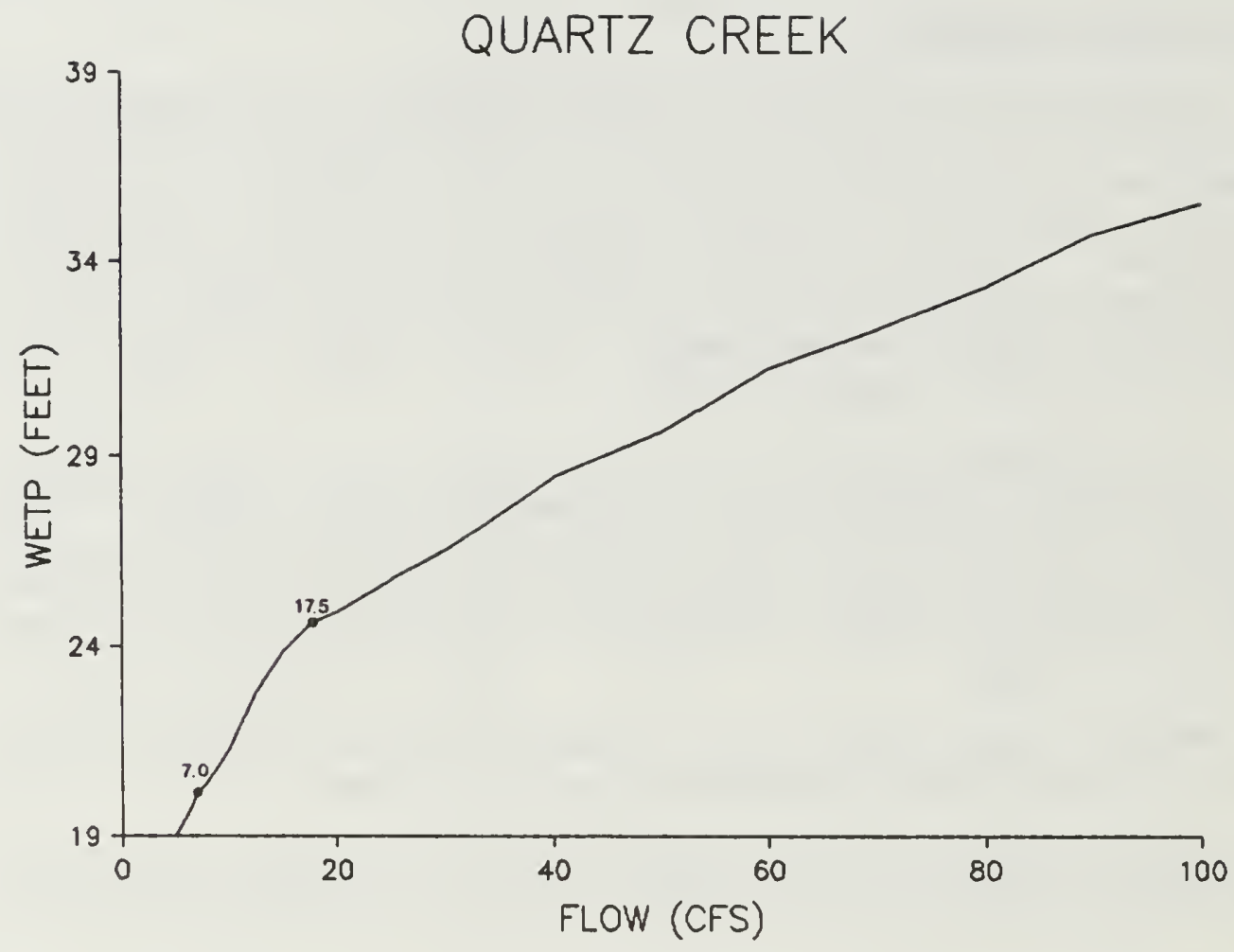

Figure 46. The wetted perimeter-discharge relationship for five riffle transects on Quartz Creek, 1985-1986. 
Table 30. The average depth for five riffle transects in Quartz Creek at selected flows of interest.

\begin{tabular}{cccccc}
\hline Flow (cfs) & CS1 & CS2 & CS3 & CS4 & CS5 \\
\hline 7.0 & .40 & .36 & .45 & .31 & .70 \\
17.5 & .56 & .55 & .65 & .44 & .66 \\
25.0 & .66 & .65 & .76 & .50 & .72 \\
\hline
\end{tabular}




\section{Description}

Stream reach: Wolf Creek from its confluence with the Fisher River (T29N, R29W, Sec. 34) to the headwaters (T32N, R26W, Sec. 31) (Figure 47 ).

Stream length: mouth to Little Wolf Creek, $25.3 \mathrm{~km}$; Little Wolf Creek to headwaters, $33.8 \mathrm{~km}$. Total drainage area: $547 \mathrm{k}^{2}$. Gradient: mouth to Little Wolf Creek, $8.7 \mathrm{~m}$ per $\mathrm{km}$; Little Wolf Creek to headwaters, $8.8 \mathrm{~m}$ per $\mathrm{km}$.

\section{Source and Land Use}

Wolf Creek originates on the west slopes of the Salish Mountains and flows south then southwest for $59.1 \mathrm{~km}$ to its confluence with the Fisher River. Approximately 65 percent of the Wolf Creek drainage listed under private and state ownership. Champion International and Burlington Northern are the major private land owners. The remainder of the watershed is in the Kootenai National Forest. Timber production is extensive in the basin as well as smaller parcels used for cattle ranching.

\section{Flows}

A continuous stage-discharge recorder was maintained by the U.S. Geological Survey, Water Resources Division, from 1967 through 1977 (T29N, R29W, Sec. 35). Mean monthly discharge and eightieth percentile exceedence flows are presented in Figure 48. Mean annual discharge is 70.2 cfs.

\section{Potential Environmental Problems}

Wolf Creek was extensively channelized during the railroad relocation 1965-1968. Construction activities denuded large expanses of land and created steep slopes along the railroad grade and in channelized portions of the creek. Increased sediment loading was severe.

Heavy timber harvesting and cattle ranching activities have increased erosion and destroyed much of the original riparian vegetation in the basin. Soils in the vicinity are predominantly unconsolidated glacio-lacustrine silts, easily eroded when vegetation cover is depleted, resulting in increased sediment pollution and damage to the fishery habitat (May 1972). 


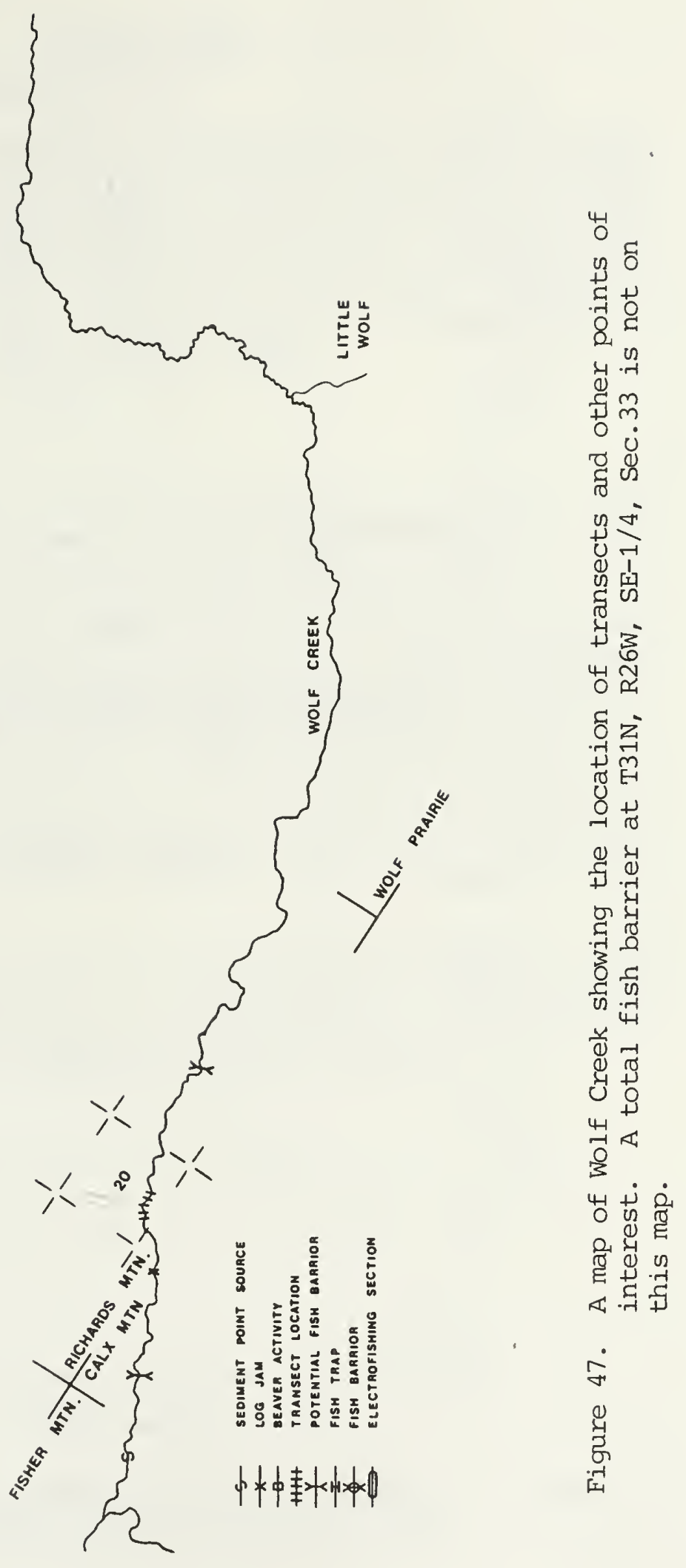




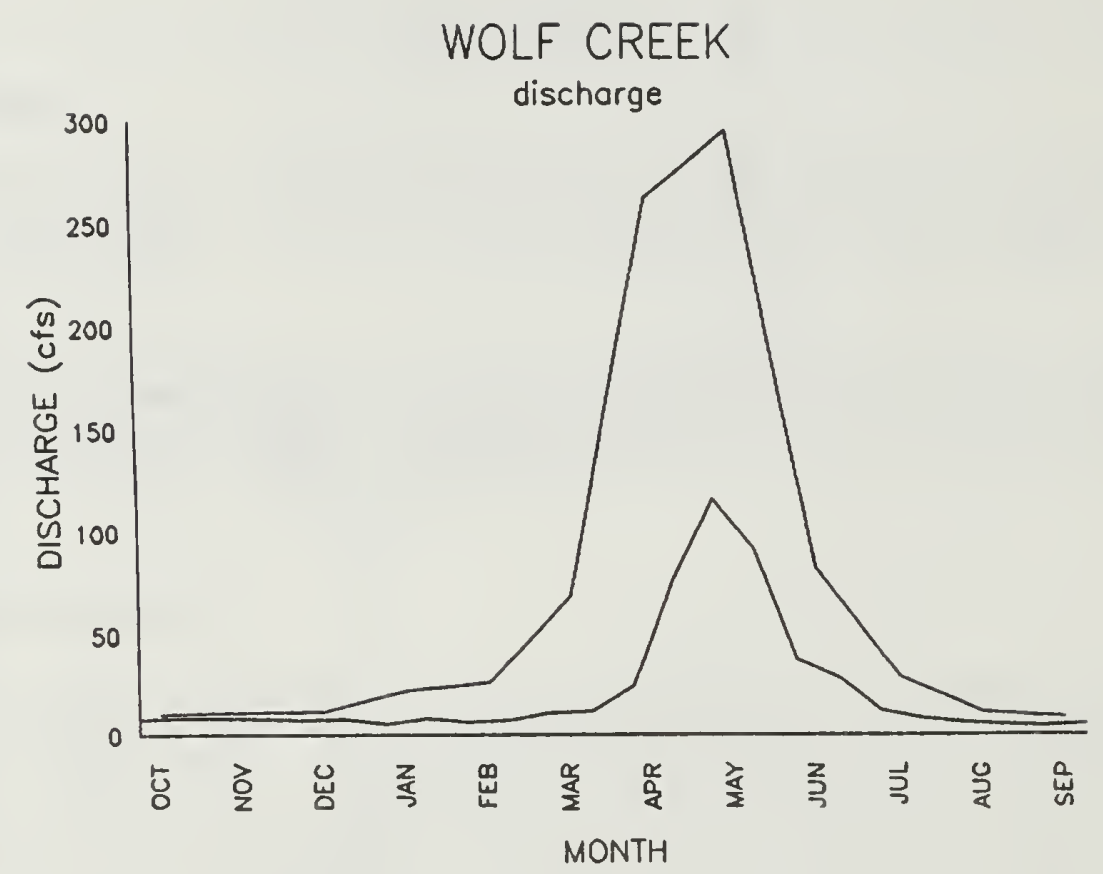

Figure 48. Mean monthly flows (top line) and eightieth percentile exceedence flows (bottom line) based on ten years of daily stage records for Wolf Creek (USGS.

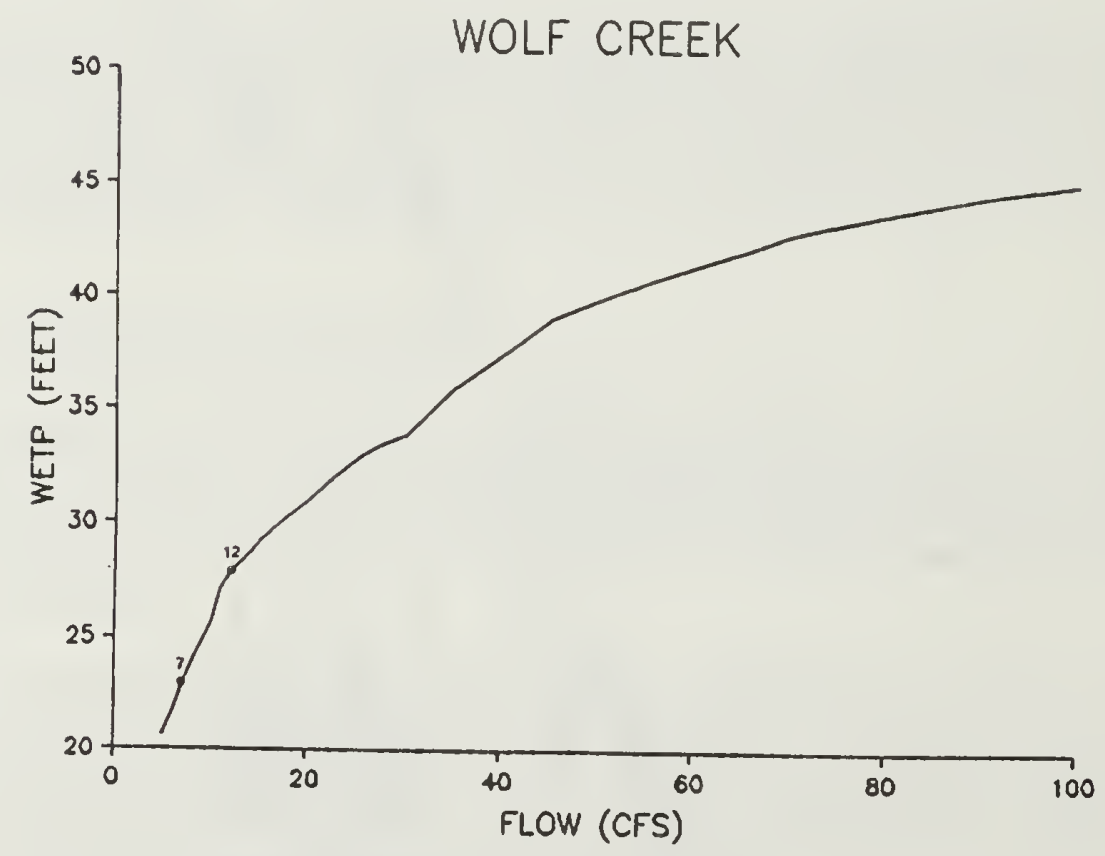

Figure 49. The wetted perimeter-discharge relationship for five riffle transects on Wolf Creek 1985-1986. 


\section{FISH POPULATIONS}

\section{Resident and Pre-emigrant Fish}

A mark-recapture population assessment was conducted during August, 1986, on a 243.8-m section representative of Wolf Creek chosen for its location between two natural channel features presenting impedance to fish movement (T29N, R28W, Sec. 29). Game fish were primarily rainbow trout (80) resulting in an estimate of $455 \pm 148$ rainbow trout $(\geq 75 \mathrm{~mm})$ per $\mathrm{km}$, and fewer numbers of mountain whitefish (1). A length-frequency histogram presents rainbow trout modal lengths (Appendix A26).

\section{FLOW RECOMMENDATIONS}

Five transects were permanently installed across riffle areas in Wolf Creek (T29N, R28W, Sec. 29). The WETP program was calibrated to stage and discharge measurements at flows of 11.0, 37.5, and $275.8 \mathrm{cfs}$. The lower and upper inflection points in a plot of the wetted perimeter-discharge relationship occur at flows of 7.0 and $12.0 \mathrm{cfs}$, respectively (Figure 49). Based on existing fish populations, the wetted perimeter analysis and water availability, a flow of $12.0 \mathrm{cfs}$ is recommended for the low flow period from July 1 through March 31. Discharge declines to below the recommended minimum flow during a portion of this period during 8 of 10 water years indicating that fish habitat is sometimes suboptimal during portions of some water years (Table 31). Recommended flows amount to 34.5 percent of the mean annual discharge on record.

A minimum average depth of $0.5 \mathrm{ft}$ is not reached until flows equal or exceed $15 \mathrm{cfs}$ (Table 32). Consequently, a passage flow of $15 \mathrm{cfs}$ is recommended for the period from April 1 through June 30 to assure successful passage of spawning migrants. 
Table 31. Recommended minimum flows for Wolf Creek and historical water availability records based on ten years of daily records (USGS).

\begin{tabular}{|c|c|c|c|c|}
\hline $\begin{array}{l}\text { Period of } \\
\text { Water Year }\end{array}$ & $\begin{array}{c}\text { Recommended } \\
\text { Flows }\end{array}$ & $\begin{array}{l}80 \% \text { Exceedence } \\
\text { Flows } \\
\end{array}$ & $\begin{array}{l}\text { Mean } \\
\text { Flows }\end{array}$ & $\begin{array}{l}\text { Acre } \\
\text { Feet }\end{array}$ \\
\hline 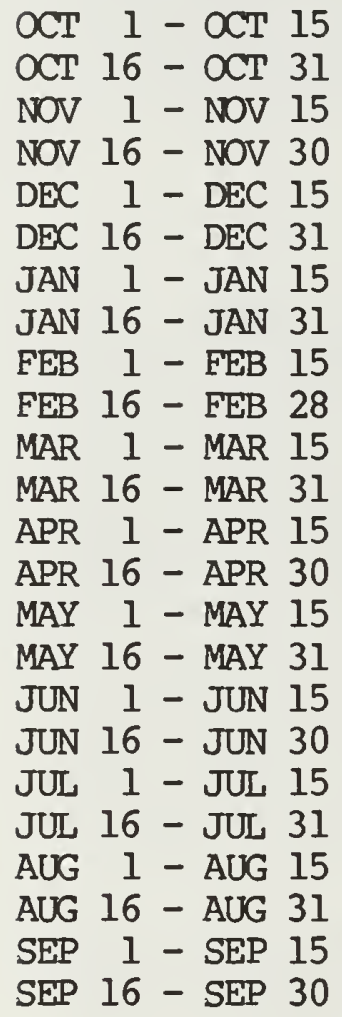 & $\begin{array}{l}12.0 \\
12.0 \\
12.0 \\
12.0 \\
12.0 \\
12.0 \\
12.0 \\
12.0 \\
12.0 \\
12.0 \\
12.0 \\
12.0 \\
24.0 \\
77.0 \\
116.0 \\
91.0 \\
38.0 \\
29.0 \\
13.0 \\
12.0 \\
12.0 \\
12.0 \\
12.0 \\
12.0\end{array}$ & $\begin{array}{r}8.2 \\
8.6 \\
8.6 \\
8.1 \\
7.8 \\
8.3 \\
5.8 \\
8.6 \\
6.8 \\
7.8 \\
11.2 \\
11.9 \\
24.3 \\
76.7 \\
116.3 \\
91.3 \\
37.9 \\
29.1 \\
12.8 \\
8.7 \\
6.4 \\
5.2 \\
4.7 \\
5.8\end{array}$ & $\begin{array}{r}10.5 \\
10.5 \\
11.4 \\
11.4 \\
12.0 \\
12.0 \\
22.2 \\
22.2 \\
26.6 \\
26.6 \\
68.8 \\
68.8 \\
263.1 \\
263.1 \\
295.7 \\
295.7 \\
82.3 \\
82.3 \\
29.6 \\
29.6 \\
11.5 \\
11.5 \\
9.2 \\
9.2\end{array}$ & $\begin{array}{r}312.3 \\
333.1 \\
339.1 \\
339.1 \\
356.9 \\
380.7 \\
660.3 \\
704.4 \\
791.2 \\
633.0 \\
2046.5 \\
2182.9 \\
7825.9 \\
7825.9 \\
8795.6 \\
9382.0 \\
2448.0 \\
2448.0 \\
880.5 \\
939.1 \\
342.1 \\
364.9 \\
273.7 \\
273.7\end{array}$ \\
\hline & & & & 50849.4 \\
\hline
\end{tabular}

a/ A dominant discharge flow (approximated bankful discharge presently undefined) should be maintained for 24 hours during this period. 
Table 32. The average depths for five riffle transects in wolf Creek at selected flows of interest.

\begin{tabular}{cccccc}
\hline \multirow{2}{*}{ Flow (cfs) } & \multicolumn{5}{c}{ Average depth (ft) } \\
\cline { 2 - 5 } 7 & CSl & CS2 & CS3 & CS4 & CS5 \\
12 & .35 & .40 & .44 & .48 & .47 \\
15 & .44 & .47 & .47 & .66 & .54 \\
\hline
\end{tabular}


The following is a summary of several tributaries researched by May (1982), reanalyzed with the updated wetted perimeter analysis. The new program equates the lowest elevation in each riffle cross section to water stage at zero flow. This provides a known intercept in the log-linear relationship between stage and discharge, increasing accuracy in the calculation of predicted water stage at selected low discharges. The result is increased sensitivity in the estimation of wetted perimeter at flows of interest.

\section{Bobtail Creek}

Bobtail Creek from its confluence with the Kootenai River (T3IN, R3IW, Sec. 30) to the junction of Bull Creek (T3IN, R3IW, Sec. 5).

Inflection points occur at 5 and $10 \mathrm{cfs}$ (Figure 50).

A minimum flow of $5 \mathrm{cfs}$ is recommended for the low flow period from July 1 through March 31.

The fish passage requirement is met when flows equal or exceed 18 cfs (Table 33). A passage flow of at least 18 cfs should be maintained from April i through June 30.

\section{East Fork of the Bull River}

East fork of the Bull River from its confluence with the Bull River (T27N, R33W, Sec. 12) upstream to the junction of the East and North forks (T27N, R32W, Sec. 14).

Inflection points occur at 20 and $50 \mathrm{cfs}$ (Figure 51).

As the recommended migrant passage depth is met when flows equal or exceed $10 \mathrm{cfs}$ (Table 34), a flow of $35 \mathrm{cfs}$ is recommended year-round to maintain fishery habitat and to assure successful migrant passage. The recommended flow is set at $35 \mathrm{cfs}$ rather than the optimum flow of $50 \mathrm{cfs}$ because available flows in the East Fork generally fall below $50 \mathrm{cfs}$, and $35 \mathrm{cfs}$ is appropriate for maintaining adequate bank cover and wetted riffle areas.

\section{Fortine Creek}

Fortine Creek from its confluence with Grave Creek (T35N, R26W, Sec. 15), upstream to the junction of Edna Creek (T33N, R26W, Sec. 2).

Inflection points occur at 35 and 55 cfs (Figure 52). 


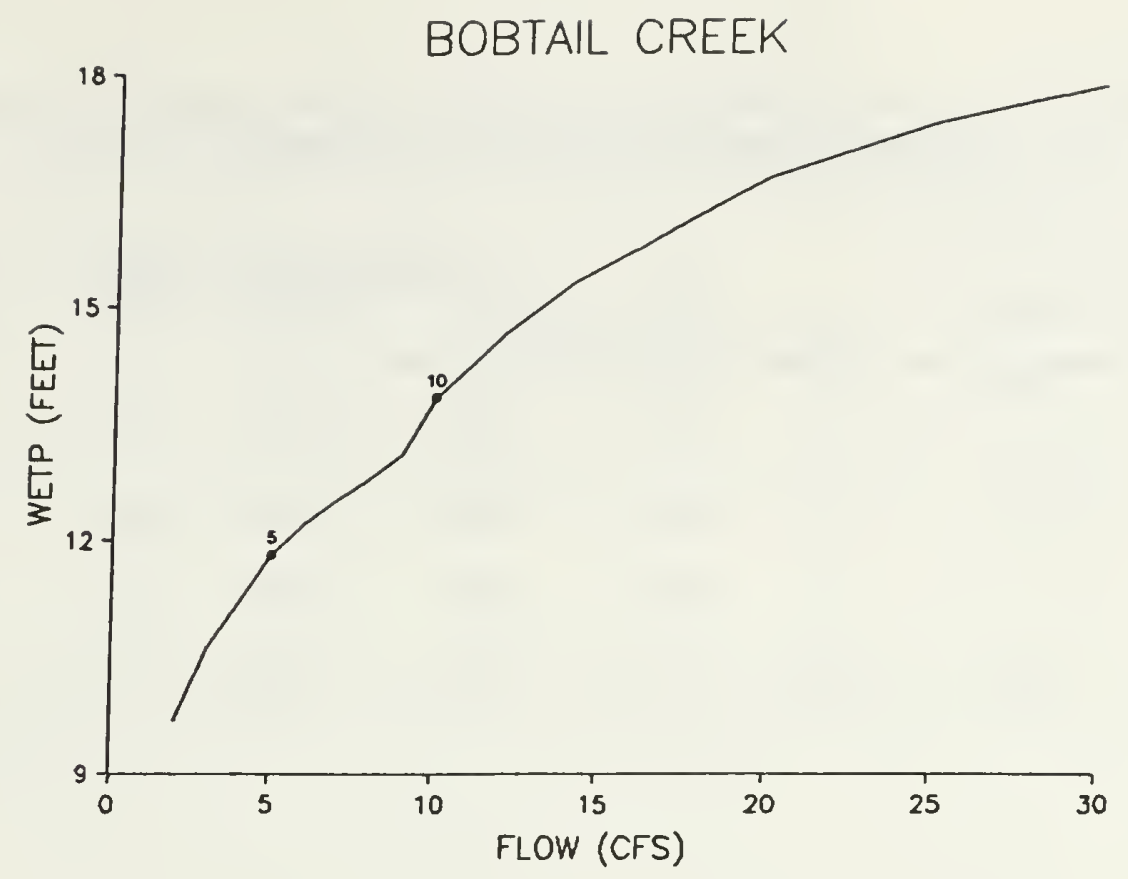

Figure 50. The wetted perimeter-discharge relationship for five riffle transects on Bobtail Creek (May 1982).

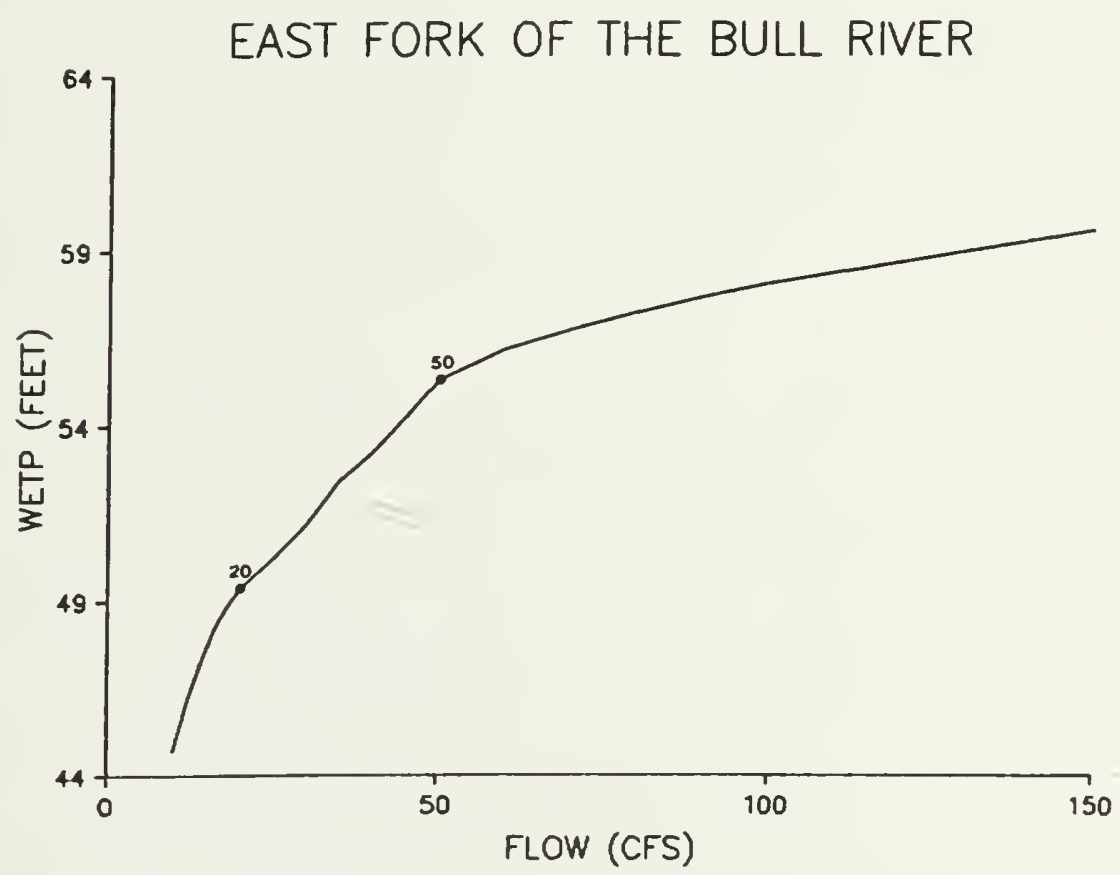

Figure 51. The wetted perimeter-discharge relationship for five riffle transects on the East Fork of the Bull River (May 1982). 
Table 33. Average depths for five riffle transects on Bobtail Creek at selected flows of interest.

\begin{tabular}{cccccc}
\hline & \multicolumn{5}{c}{ Average Depth (ft) } \\
\cline { 2 - 5 } Flow (cfs) & CS1 & CS2 & CS3 & CS4 & CS5 \\
\hline 5 & .42 & .67 & .39 & .53 & .42 \\
10 & .51 & .79 & .43 & .63 & .56 \\
18 & .60 & .86 & .52 & .73 & .70 \\
\hline
\end{tabular}


Table 34. Average depths for five riffle transects on the East Fork of the Bull River at selected flows of interest.

\begin{tabular}{ccccccc}
\hline \multirow{2}{*}{ Flow (cfs) } & \multicolumn{5}{c}{ Average Depth (ft) } \\
\cline { 2 - 5 } & CS1 & CS2 & CS3 & CS4 & CS5 \\
\hline 10 & 4.22 & .51 & .51 & .75 & .58 \\
20 & 3.33 & .63 & .63 & .92 & .74 \\
50 & 2.98 & .88 & .83 & 1.11 & .94 \\
\hline
\end{tabular}




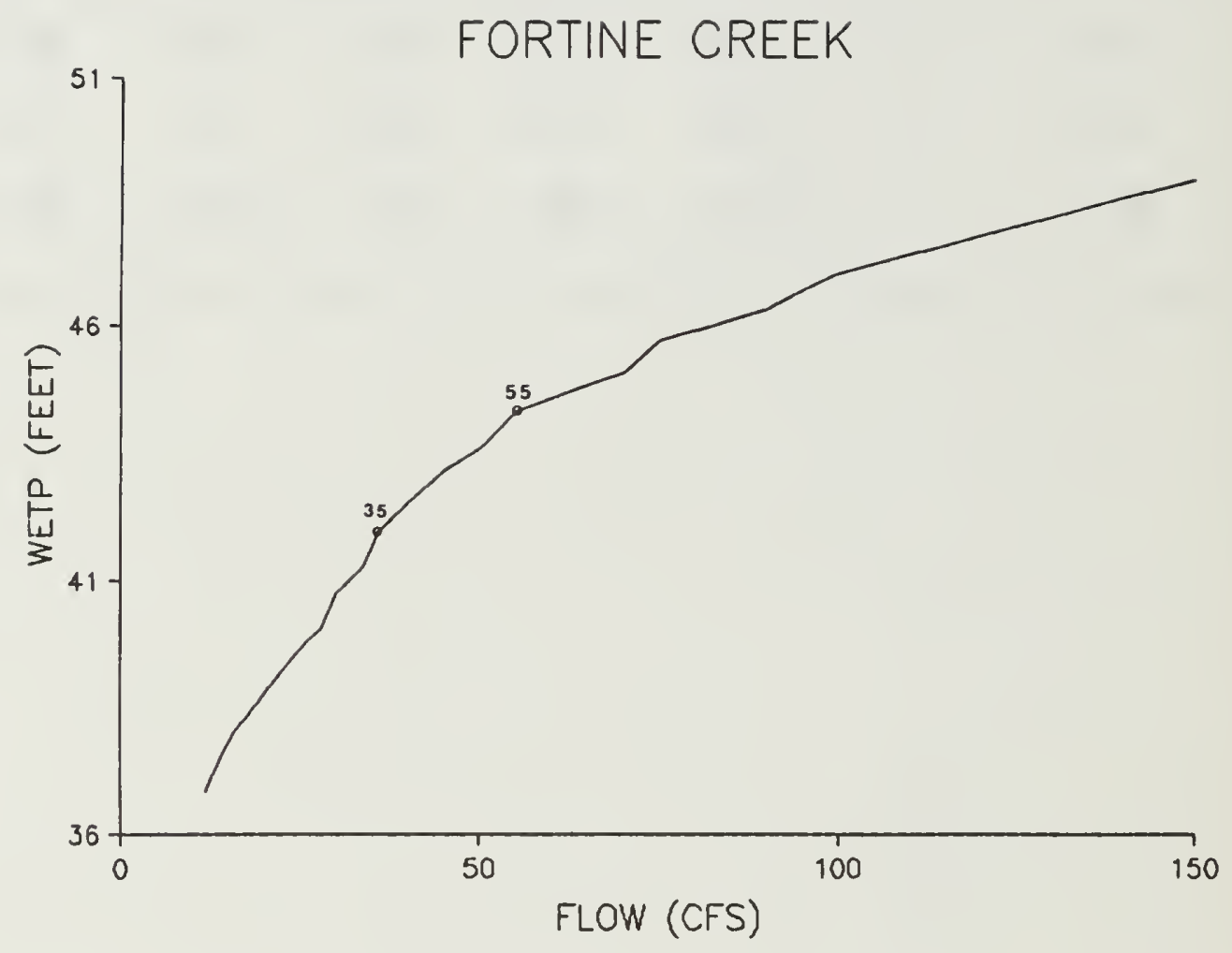

Figure 52. The wetted perimeter discharge relationship for five riffle transects on Fortine Creek (May 1982). 
The recommended fish passage depth is met when flows equal or exceed $28 \mathrm{cfs}$ (Table 35). Consequently, a flow of $40 \mathrm{cfs}$ is recommended year-round to maintain fishery habitat and to assure successful migrant passage.

\section{O'Brien Creek}

O'Brien Creek from its confluence with the Kootenai River (T3IN, R33W, Sec. 18), upstream to the junction of the North Fork (T32N, R33W, Sec. 7).

Inflection points occur at 16 and $27.5 \mathrm{cfs}$ (Figure 53).

A minimum flow of $27.5 \mathrm{cfs}$ is recommended for the low flow period from July 1 through March 31. Discharge has been observed to fall below the recommended flow during portions of some water years.

The fish passage requirement is met when flows equal or exceed $30 \mathrm{cfs}$ (Table 36). A passage flow of at least $30 \mathrm{cfs}$ should be maintained from April 1 through June 30.

\section{Pinkham Creek}

Pinkham Creek from its confluence with Libby Reservoir (T35N, R28W, Sec. 5), upstream to the junction of the East and West forks of Pinkham Creek (T34N, R27W, Sec. 32).

Inflection points occur at 5 and 35 cfs (Figure 54).

A flow of $5 \mathrm{cfs}$ is recommended for the low flow period from July 1 through March 31.

The dominant discharge/channel morphology concept was used to determine the flows during the high flow period from April 1 through June 30, rather than the fish passage criteria. The high flows that are needed to maintain existing stream morphology and provide a flushing action are higher than the flow required for fish passage.

Monthly flow recommendations for the low and high flow periods are compared in Table 37 to the median monthly flows of record, as derived from USGS flow records for the gauge near the mouth of Pinkham Creek. The flow recommendations would require that all the water during a normal water year be maintained instream from approximately August through March. 
Table 35. Average depths for five riffle transects on Fortine Creek at selected flows of interest.

\begin{tabular}{llllll}
\hline \multirow{2}{*}{ Flow (cfs) } & \multicolumn{5}{c}{ Average Depth (ft) } \\
\cline { 2 - 5 } 28 & CS1 & CS2 & CS3 & CS4 & CS5 \\
35 & .57 & .50 & .73 & .55 & .75 \\
55 & .63 & .55 & .70 & .60 & .82 \\
& .77 & .64 & .81 & .671 & .96 \\
\hline
\end{tabular}




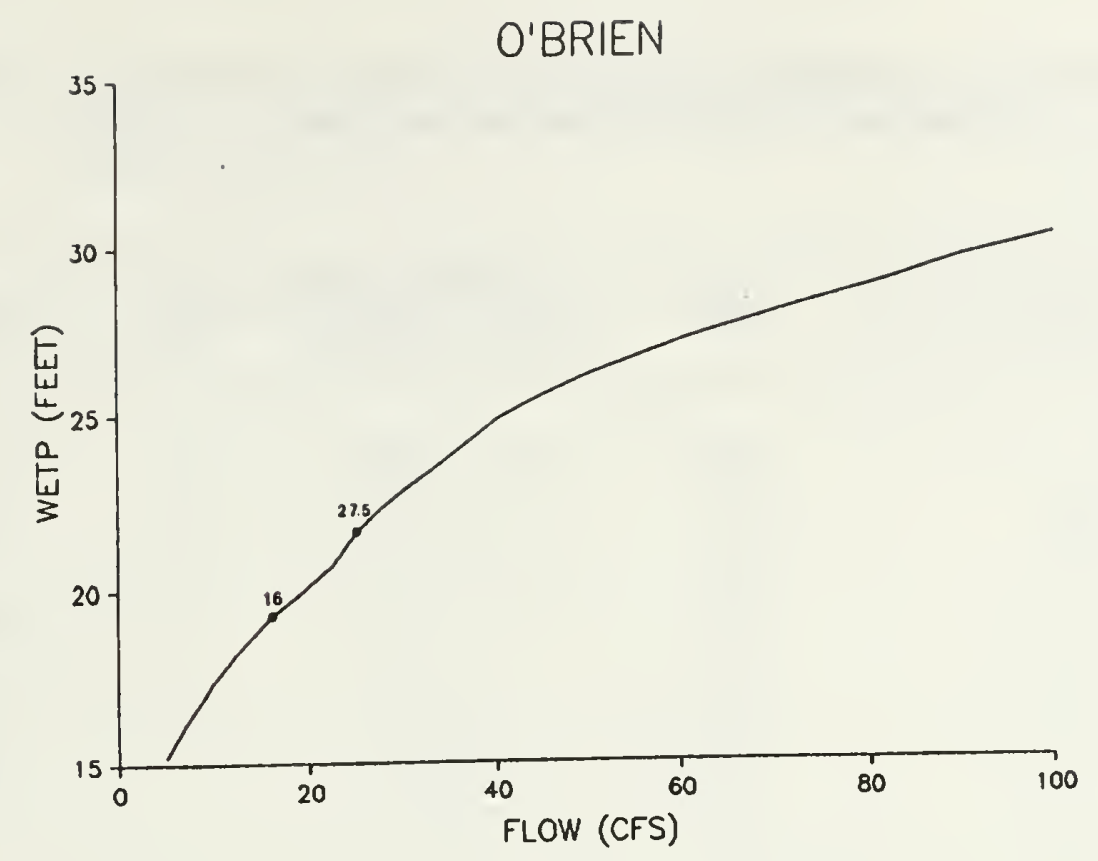

Figure 53. The wetted perimeter-discharge relationship for five riffle transects on O'Brien Creek (May 1982).

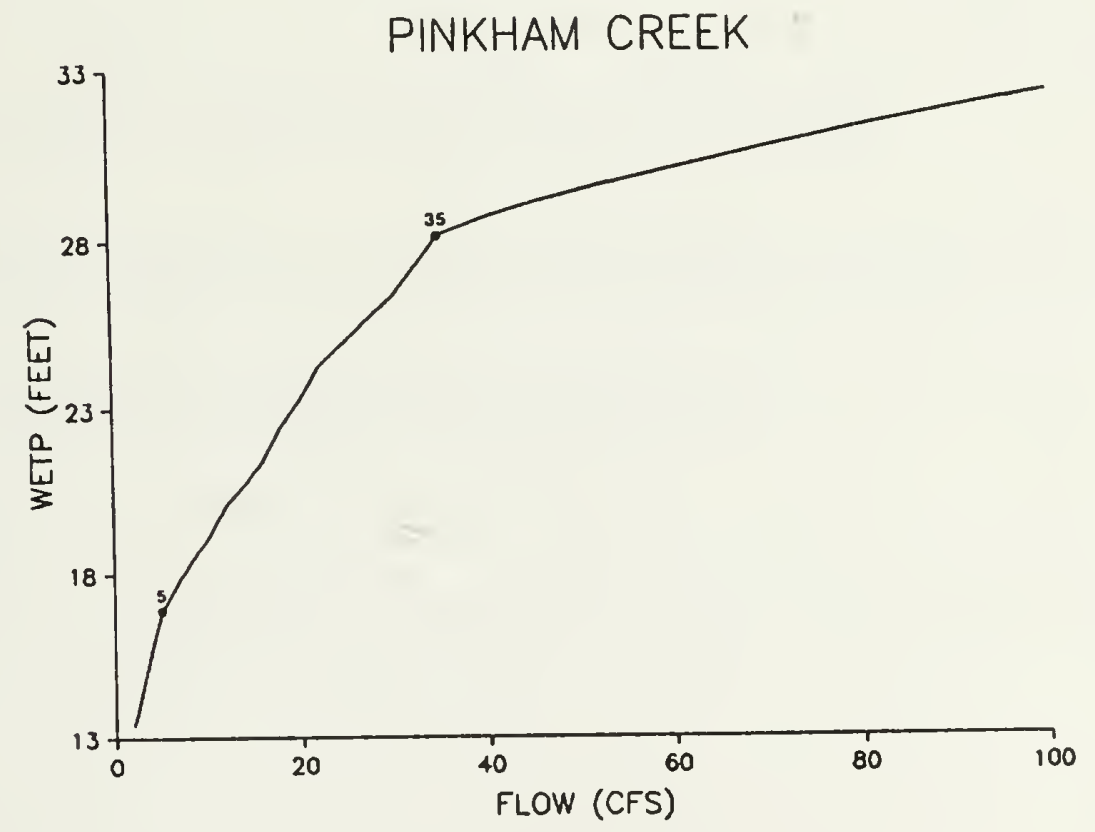

Figure 54. The wetted perimeter-discharge relationship for five riffle transects on Pinkham Creek (May 1982). 
Table 36. Average depths for five riffle transects on O'Brien Creek at selected flows of interest.

\begin{tabular}{lccccc}
\hline \multirow{2}{*}{ Flow (cfs) } & \multicolumn{5}{c}{ Average Depth (ft) } \\
\cline { 2 - 5 } 16 & CS1 & CS2 & CS3 & CS4 & CS5 \\
27.5 & .63 & .54 & .41 & .71 & .54 \\
30 & .69 & .63 & .49 & .77 & .66 \\
& .71 & .64 & .51 & .77 & .68 \\
\hline
\end{tabular}


Table 37. Comparison of the instream flow recommendations for Pinkham Creek to the approximated median flows of record (May 1982).

\begin{tabular}{|c|c|c|c|}
\hline & $\begin{array}{l}\text { Instream Flow } \\
\text { Recommendations a/ }\end{array}$ & Approx & $\begin{array}{l}\text { Median Flows } \\
\text { ord }\end{array}$ \\
\hline & CFS & CFS & $\underline{A F}$ \\
\hline January & 5.0 & 1.72 & 108 \\
\hline February & 5.0 & 1.24 & 69 \\
\hline March & 5.0 & 4.93 & 303 \\
\hline April 1-15 & 5.3 & 20.6 & 613 \\
\hline April 16-30 & 36.3 & 76.3 & 2,270 \\
\hline May 1-15 & $73.5 \mathrm{c} /$ & 128.3 & 3,816 \\
\hline May 16-31 & 50.2 & 116.9 & 3,709 \\
\hline June $1-15$ & 31.0 & 54.4 & 1,618 \\
\hline June $16-30$ & 11.0 & 31.3 & 931 \\
\hline July & 5.0 & 9.97 & 613 \\
\hline August & 5.0 & 1.38 & 85 \\
\hline September & 5.0 & 0.79 & 47 \\
\hline October & 5.0 & 0.66 & 41 \\
\hline November & 5.0 & 3.01 & 179 \\
\hline December & 5.0 & 2.32 & $\frac{143}{14.545} \mathrm{~d} /$ \\
\hline
\end{tabular}

a/ Derived using the wetted perimeter/inflection point method and the dominant discharge/channel morphology concept.

b/ Derived from flow records for a 9-year period of record (between 1973 and 1981 water years) for the USGS gauge on Pinkahm Creek, $1.5 \mathrm{~km}$ upstream from Lake Koocanusa.

c) The bankful discharge, which is presently undefined, should be maintained for 24 hours during this period.

d/ Appoximate volume of water normally available on an annual basis. 


\section{Pipe Creek}

Pipe Creek from its confluence with the Kootenai River (T31N, R31W, Sec. 30), upstream to the junction of the East Fork (T33N, R3lW, Sec. 16).

Inflection points occur at 16.0 and $27.5 \mathrm{cfs}$ (Figure 55).

A minimum flow of $16 \mathrm{cfs}$ is recommended for the low flow period from July 1 through March 31 . Water availability does not normally suport the optimum flow of $27.5 \mathrm{cfs}$.

The fish passage requirement is met when flows equal or exceed $25 \mathrm{cfs}$ (Table 38). flow of at least $25 \mathrm{cfs}$ should be maintained from April 1 through June 30.

\section{Rock Creek}

Rock Creek from its mouth on the Clark Fork near Noxon, Montana (T26N, R32W, Sec. 32), upstream to Rock Creek Meadows (T26N, R31W, Sec. 6).

Inflection points occur at 9.0 and $16.0 \mathrm{cfs}$ (Figure 56).

The recommended fish passage depth is met at all transects when flows equal or exceed 10 cfs (Table 39). Consequently, a flow of $16 \mathrm{cfs}$ is recommended for the entire year to maintain fishery habitat and to ensure successful migrant passage.

\section{Ross Creek}

Ross Creek from its confluence with Bull Lake (T28N, R33W, Sec. 4), upstream to the junction of the South Fork of Ross Creek (T28N, R34W, Sec. 15).

Inflection points occur at 20 and $70 \mathrm{cfs}$ (Figure 57).

A minimum flow of $20 \mathrm{cfs}$ is recommended for the low flow period from July 1 through March 31.

The fish passage requirement is met when flows equal or exceed $30 \mathrm{cfs}$. A flow of at least $30 \mathrm{cfs}$ should be maintained from April 1 through March 31 (Table 40).

\section{Yaak River}

Yaak River from its mouth on the Kootenai River (T32N, R34W, Sec. 5), upstream to the Yaak Falls (T33N, R33W, Sec. 4). Yaak Falls upstream to its confluence with Spread Creek (T35N, R33W, Sec. 10). 


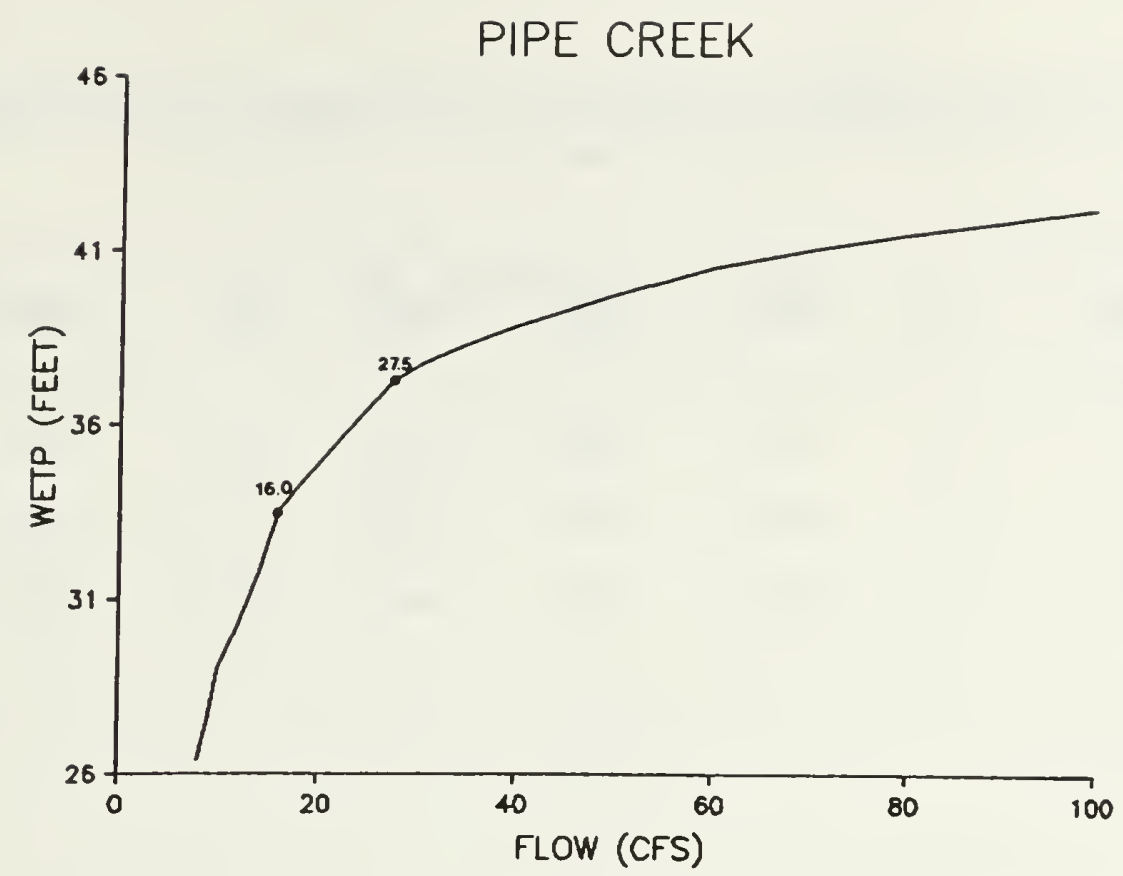

Figure 55. The wetted perimeter-discharge relationship : i five riffle transects on Pipe Creek (May 1982).

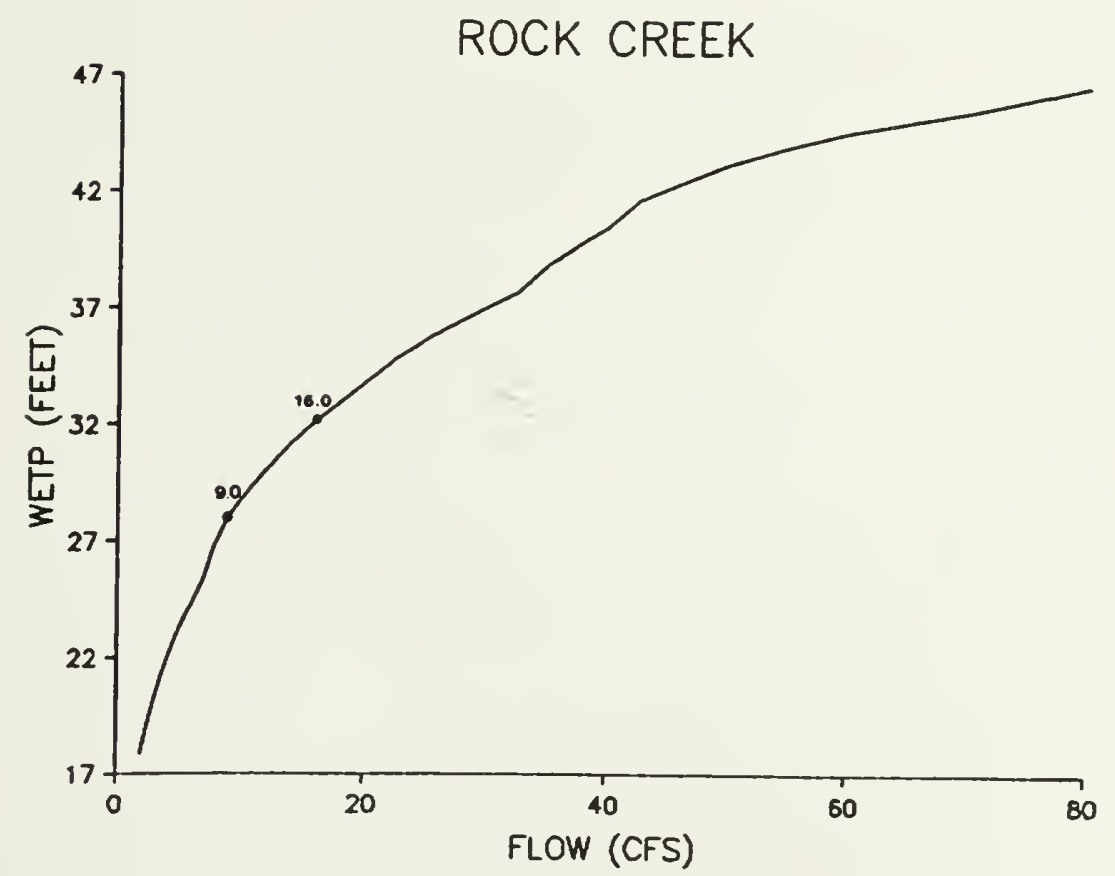

Figure 56. The wetted perimeter-discharge relationship for 1 ive riffle transects on Rock Creek (May 1982). 
Table 38. Average depths for five riffle transects on Pipe Creek at selected flows of interest.

\begin{tabular}{cccccc}
\hline & \multicolumn{5}{c}{ Average Depth (ft) } \\
\cline { 2 - 5 } Flow (cfs) & CS1 & CS2 & CS3 & CS4 & CS5 \\
\hline 16 & .67 & .40 & .47 & .64 & .41 \\
25 & .65 & .52 & .55 & .76 & .52 \\
& .65 & .55 & .56 & .78 & .54 \\
\hline
\end{tabular}


Table 39. Average depths for five riffle transects on Rock Creek at selected flows of interest.

\begin{tabular}{cccccc}
\hline \multirow{2}{*}{ Flow (cfs) } & \multicolumn{5}{c}{ Average Depth (ft) } \\
\cline { 2 - 6 } 9 & CS1 & CS2 & CS3 & CS4 & CS5 \\
\hline 10 & .52 & .60 & .49 & .57 & .73 \\
16 & .53 & .62 & .52 & .59 & .76 \\
\hline
\end{tabular}




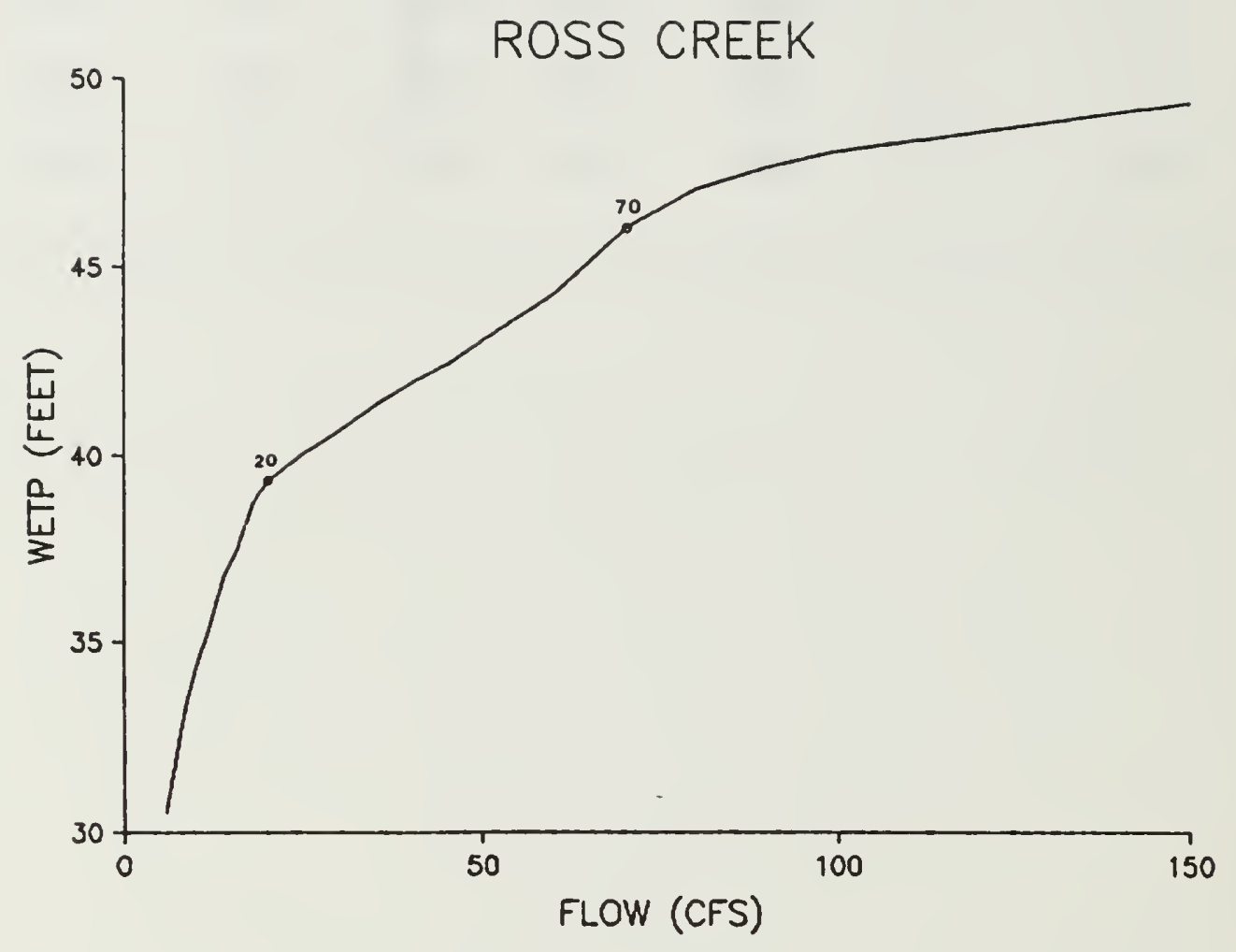

Figure 57. The wetted perimeter-discharge relationship for five riffle transects on Ross Creek (May 1982). 
Table 40. Average depths for five riffle transects of Ross Creek at selected flows of interest.

\begin{tabular}{lccccc}
\hline \multirow{2}{*}{ Flow (cfs) } & \multicolumn{5}{c}{ Average Depth (ft) } \\
\cline { 2 - 5 } & CS1 & CS2 & CS3 & CS4 & CS5 \\
\hline 30 & 1.10 & .42 & .51 & .73 & .74 \\
70 & 1.23 & .52 & .62 & .80 & .86 \\
& 1.56 & .78 & .89 & .78 & 1.14 \\
\hline
\end{tabular}


Yaak River mean monthly discharge and eightieth percentile exceedence flows are provided in the annual hydrograph (Figure 58).

Inflection points occurred at 110 and $170 \mathrm{cfs}$ in the Lower Yaak River and 97.5 and 145 in the upstream reach (Figures 59 and 60). Due to the high fishery value of the Yaak River and similarities in the hydrology within the two reaches, an overall flow recommendation is set for the entire designated length of river (Table 41). A minimum passage flow of $77.5 \mathrm{cfs}$ will be satisfied if instream flow recommendations are implemented as stated. Recommended flows in the lower section amount to 45.6 percent of the mean annual flow on record.

\section{Young Creek}

Young Creek from its confluence with Libby Reservoir (T37N, $\mathrm{R} 28 \mathrm{~W}$, Sec. 24) upstream to the confluence of the South Fork (T37N, $\mathrm{R} 29 \mathrm{~W}, \mathrm{Sec}, 14$ ).

Inflection points occur at 3.0 and $8.0 \mathrm{cfs}$ (Figure 61).

Based on a reanalysis of data compiled by May (1982) an optimal minimum flow was identified as $8 \mathrm{cfs}$; however a flow of 5 cfs was previously applied to Young Creek for the low flow period from July 1 through April 30. To be consistent with previous recommendations, the minimum flow recommendation will be maintained as stated.

The fish passage requirement is met when flows equal or exceed $30 \mathrm{cfs}$ ( $\mathrm{Table}$ 42). A passage flow of at least $30 \mathrm{cfs}$ is needed to ensure successful migrant passage; however, a passage flow of 25 cfs was previously applied to the period from May 1 through June 30 , therefore the recommended flow will be maintained at 25 cfs. This should be adequate to maintain passage. 


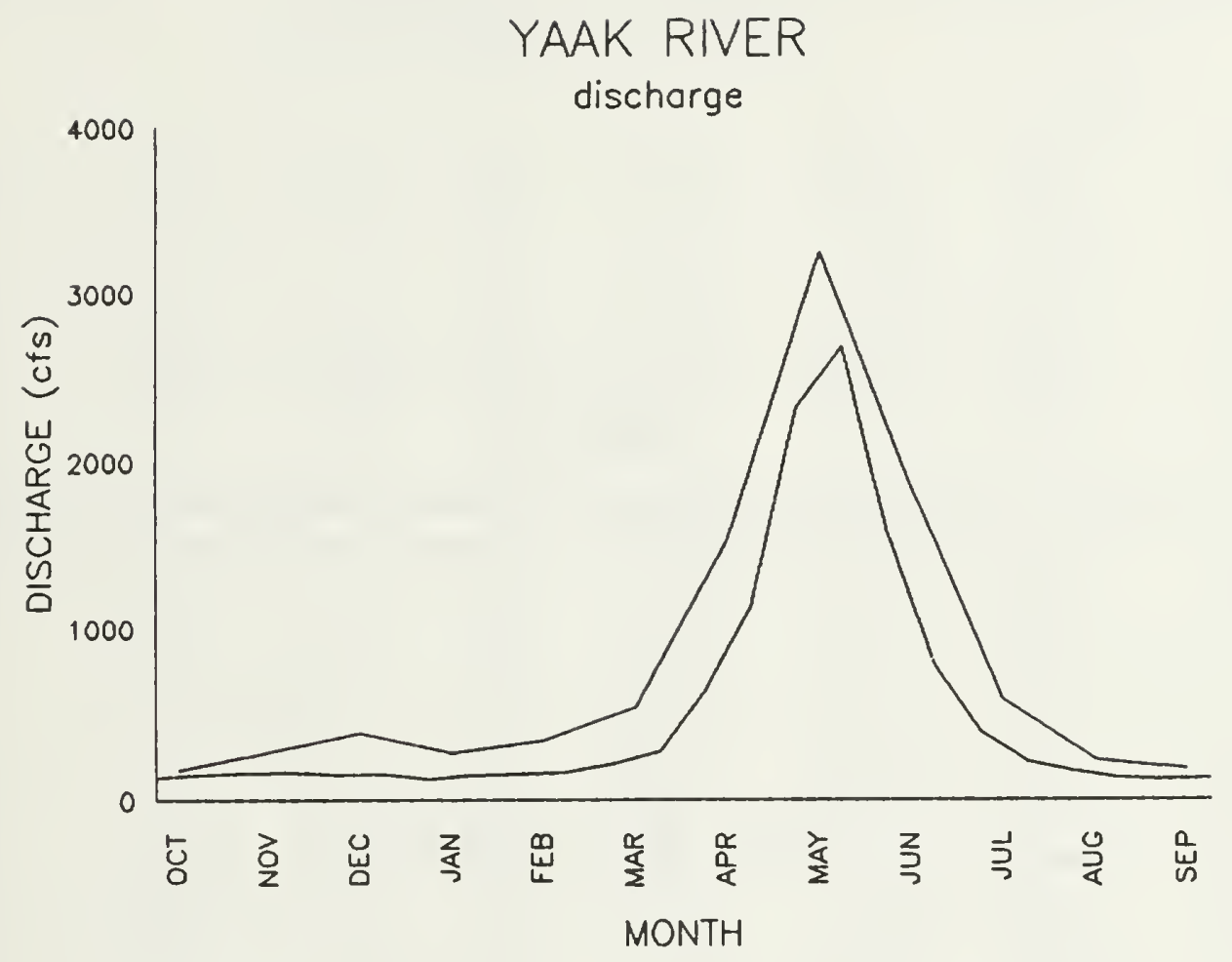

Figure 58. Mean monthly flows (top line) and eightieth percentile exceedence flows (bottom line) based on ten years of daily stage records for the Yaak River (USGS). 


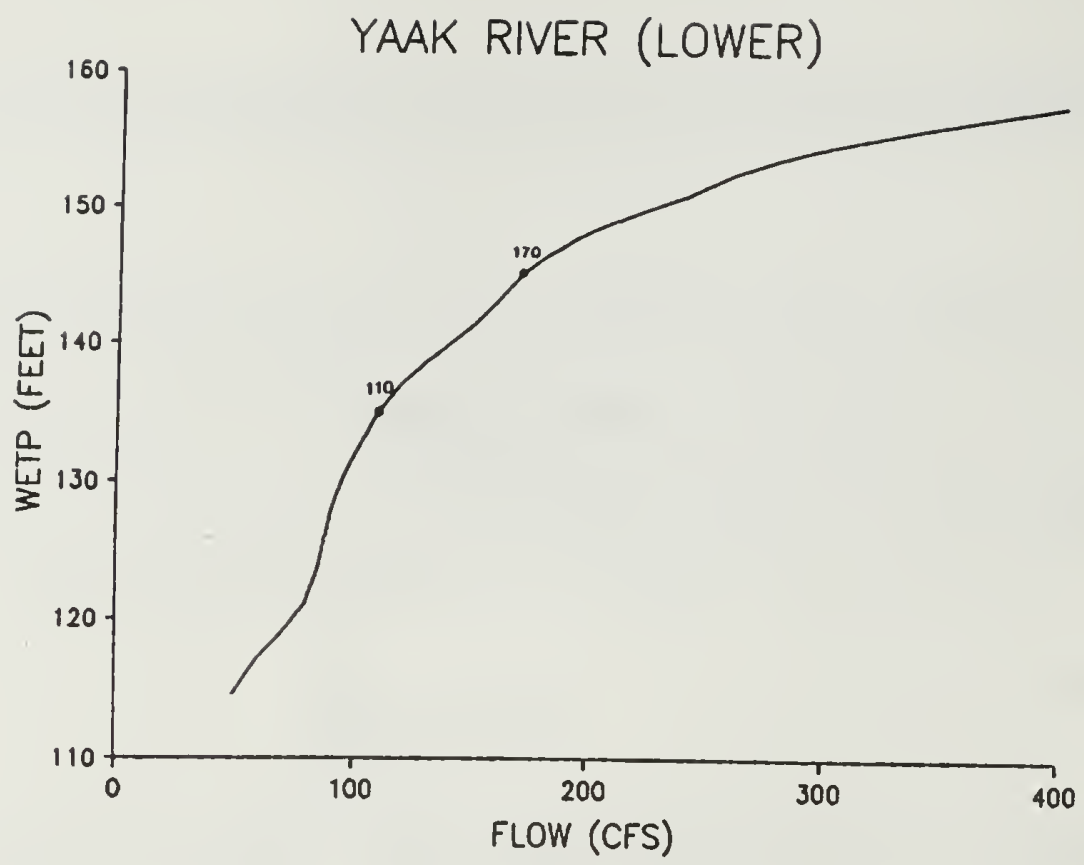

Figure 59. The wetted perimeter-discharge relationship for five riffle transects on the lower Yaak River (May 1982).

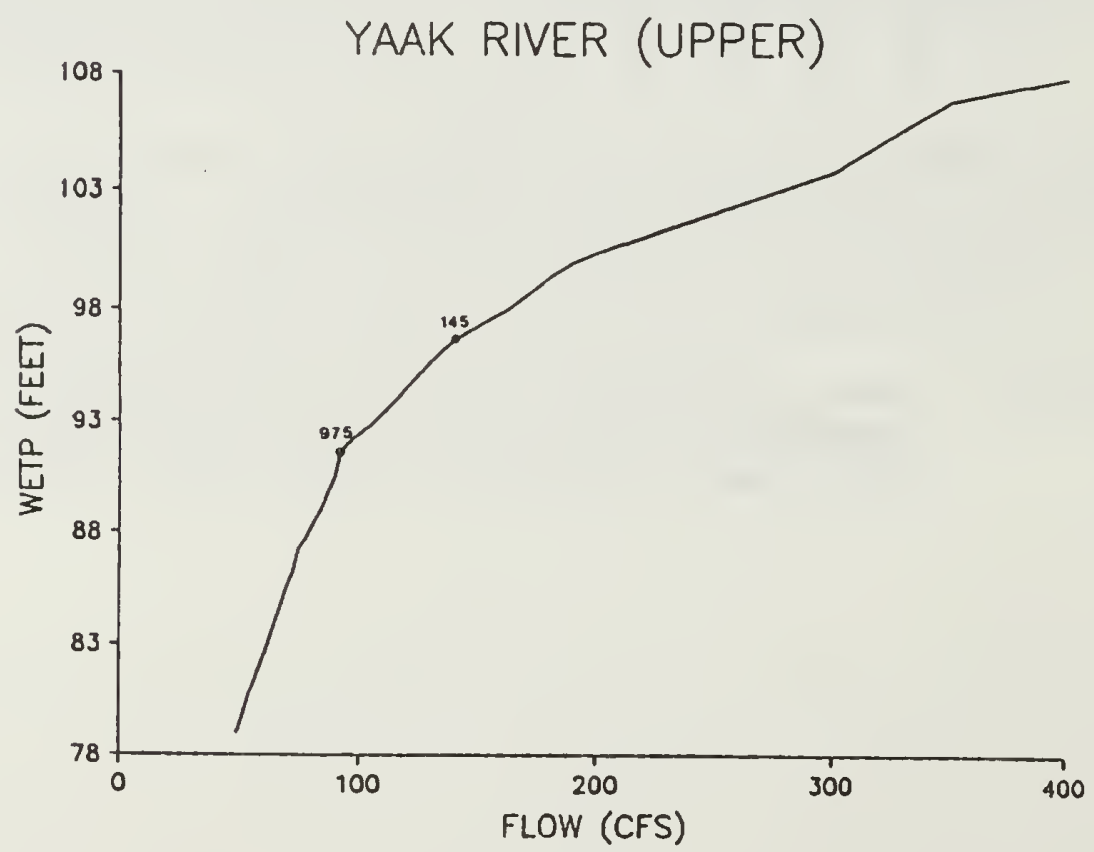

Figure 60. The wetted perimeter-discharge relationship for five riffle transects on the upper Yaak River (May 1982). 
Table 4l. Recommended minimum flows for the Yaak River and historical water availability records based on ten years of daily records (USGS).

\begin{tabular}{|c|c|c|c|c|c|}
\hline \multirow[t]{2}{*}{$\begin{array}{c}\text { Period of } \\
\text { water Year }\end{array}$} & $\begin{array}{l}\text { Recommended } \\
\text { Flows }\end{array}$ & \multirow{2}{*}{$\begin{array}{l}80 \% \\
\text { Exceedence } \\
\text { Flows }\end{array}$} & \multirow{2}{*}{\multicolumn{2}{|c|}{$\begin{array}{l}\text { Mean Acre } \\
\text { Flows Feet }\end{array}$}} & \multirow[t]{2}{*}{$\begin{array}{l}\text { Median } \\
\text { Flows }\end{array}$} \\
\hline & (lower) (upper) & & & & \\
\hline
\end{tabular}

$\begin{array}{lrrrrrrr}\text { OCT 1 - OCT 15 } & 170.0 & 145.0 & 128.8 & 168.5 & 5012.0 & 183 \\ \text { OCT 16 - OCT 31 } & 170.0 & 145.0 & 144.0 & 168.5 & 5346.2 & 183 \\ \text { NOV 1 - NOV 15 } & 170.0 & 145.0 & 154.1 & 273.5 & 8135.3 & 231 \\ \text { NOV 16 - NOV 30 } & 170.0 & 145.0 & 155.9 & 273.5 & 8135.3 & 231 \\ \text { DEC 1 - DEC 15 } & 170.0 & 145.0 & 144.7 & 384.8 & 11445.9 & 219 \\ \text { DEC 16 - DEC 31 } & 170.0 & 145.0 & 146.9 & 384.8 & 12208.9 & 219 \\ \text { JAN 1 - JAN 15 } & 170.0 & 145.0 & 119.0 & 269.0 & 8001.4 & 233 \\ \text { JAN 16 - JAN 31 } & 170.0 & 145.0 & 141.3 & 269.0 & 8534.8 & 233 \\ \text { FEB 1 - FEB 15 } & 170.0 & 145.0 & 146.7 & 339.4 & 10095.4 & 319 \\ \text { FEB 16 - FEB 28 } & 170.0 & 145.0 & 156.8 & 339.4 & 8076.4 & 319 \\ \text { MAR 1 - MAR 15 } & 170.0 & 145.0 & 205.3 & 530.7 & 15785.7 & 404 \\ \text { MAR 16 - MAR 31 } & 170.0 & 145.0 & 270.6 & 530.7 & 16838.1 & 404 \\ \text { APR 1 - APR 15 } & 300.0 & 300.0 & 624.8 & 1,524.3 & 45340.3 & 1,006 \\ \text { APR 16 - APR 30 } 300.0 & 600.0 & 1,129.1 & 1,524.3 & 45340.3 & 1,375 \\ \text { MAY 1 - MAY 15C/ } 1200.0 & 1200.0 & 2,326.0 & 3,246.3 & 96561.2 & 3,372 \\ \text { MAY 16 - MAY 31 } 1800.0 & 1800.0 & 2,681.8 & 3,246.3 & 10299.8 & 4,302 \\ \text { JUN 1 - JUN 15 } & 1200.0 & 1200.0 & 1,556.0 & 1,844.5 & 54864.7 & 2,914 \\ \text { JUN 16 - JUN 30 } & 600.0 & 600.0 & 776.5 & 1,844.5 & 54864.7 & 1,410 \\ \text { JUL 1 - JUL 15 } & 300.0 & 300.0 & 392.7 & 578.8 & 17216.4 & 707 \\ \text { JUL 16 - JUL 31 } & 170.0 & 145.0 & 220.8 & 578.8 & 18364.1 & 343 \\ \text { AUG 1 - AUG 15 } & 170.0 & 145.0 & 166.9 & 225.5 & 6707.5 & 196 \\ \text { AUG 16 - AUG 31 } & 170.0 & 145.0 & 125.8 & 225.5 & 7154.7 & 196 \\ \text { SEP 1 - SEP 15 } & 170.0 & 145.0 & 116.0 & 175.0 & 5205.4 & 164 \\ \text { SEP 16 - SEP 30 } & 170.0 & 145.0 & 122.8 & 175.0 & 5205.4 & 164 \\ & & & & & & & \end{array}$

a/ Derived from the dominant discharge/channel morphology concept, the wetted perimeter/inflection point method and the trout passage requirement.

b) Derived from a nine-year period of record (1965-1973) for the USGS gauge located $.32 \mathrm{~km}$ upstream from the mouth of the Yaak River.

c) A flow of $6,400 \mathrm{cfs}$ (the approximate bankful discharge) should be maintained for 24 hours during this period (May 1982). 


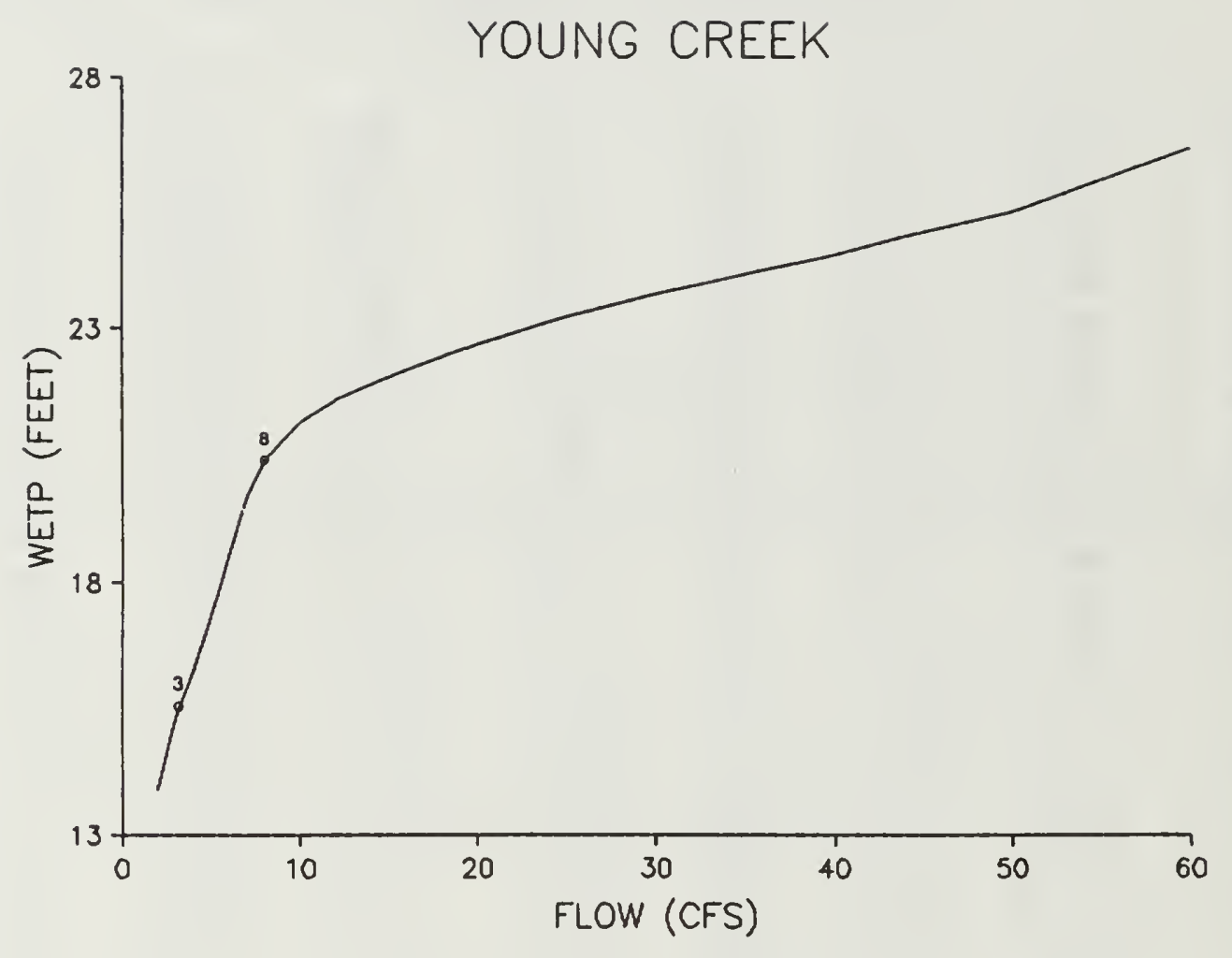

Figure 61. The wetted perimeter-discharge relationship for five riffle transects on Young Creek (May 1982). 
Table 42. Average depths for five riffle transects on Young Creek at selected flows of interest.

\begin{tabular}{cccccc}
\hline & \multicolumn{5}{c}{ Average Depth (ft) } \\
\cline { 2 - 6 } Flow (cfs) & CS1 & CS2 & CS3 & CS4 & CS5 \\
3 & .37 & .19 & .31 & .38 & .17 \\
8 & .55 & .26 & .48 & .43 & .27 \\
30 & .78 & .52 & .74 & .88 & .47 \\
\hline
\end{tabular}




\section{Instream Flow}

To maintain the spawning potential of the stream, it is important that instream flow recommendations resulting from investigations in the Kootenai watershed be protected by application to the DNRC. A basin-wide approach should be implemented with flow recommendations filed in groups based on the degree of conflict, stream location and fishery information, to facilitate consideration. This should be accomplished with minimum delay to secure a timely priority date and to balance fishery requirements with future water use. Major forks of the tributaries in this report, and upper stream reaches exhibiting dissimilar hydrologic characteristics, should be researched to clarify instream flow needs.

\section{Fish Populations}

Fish population estimates were performed during late summer and fall to avoid the capture of Salmo spp. during their spawning run and to target resident and pre-emigrant fish. Electrofishing results do not identify the stream's importance to spawning adults but instead indicate the streams ability to support a resident population and recruits. In this study, the location of the sampled reach corresponded to a representative stretch of stream near the established riffle transects. Transects were, in most cases, installed near tributary mouths where the hydrologic conditions were often erratic and fishery habitat was less optimal, and thus less capable of supporting the quantity of fish than portions further upstream. For this reason, population surveys may underestimate the tributary's importance as a rearing stream. The entire identified stream reach should be considered for placement of the sampling section.

\section{Rokanee Spawning}

Migrant kokanee salmon entered the Fisher and Tobacco rivers, and Libby Creek during fall. High autumn flows dislodged fry traps and scoured marked redds or buried them beneath thick deposits of sediment and debris, consequently, efforts to estimate fry survival in the Tobacco River failed. Further research is needed to determine the importance of Montana's Kootenai River tributaries to kokanee spawning success. It is apparent that Canadian tributaries support the majority of kokanee reproduction (Huston et al. 1984). They should be protected from degradation if kokanee are to be maintained as the most important sportfish in Libby Reservoir. 


\section{Native Rainbow Trout}

Callahan Creek is one of two Kootenai River tributaries in Montana known to contain a genetically isolated population of native rainbow trout. Genetic contamination and habitat degradation should be avoided to preserve this remaining population.

\section{Fish Barrier Removal}

A rock barrier located at the mouth of Barron Creek should be modified into a step-like cascade to allow for migrant passage during spring. The drainage is similar to Bristow Creek which developed a substantial run of westslope cutthroat, rainbow and hybrid trout. Debris and log jams deemed to be barriers should be removed from Barron, Bobtail, Bristow, Deep, Fivemile, Pinkham, Pipe and Quartz creeks to ensure access to spawning areas. Barriers may form in other tributaries as well. However, debris removal should be conservative because partial blockage of the channel is desirable for cover, pool production and gravel deposition.

Migrant passage during fall low flows is especially important in creeks supporting bull trout spawning (e.g. Grave, Libby, Pipe and Quartz creeks, and the Fisher River). Rock and log jams illegally erected to create recreational "swimming holes" should be breached prior to the low flow period when water flows through rather than over the structures, presenting barriers to migrants.

\section{Tributary Habitat}

Protection of the aquatic habitat in Rootenai River tributaries is of paramount importance to the maintenance of the resident fishery resource. This report summarizes research to support efforts to maintain existing stream flow conditions favorable for fish production. Sediment pollution and channel instability caused by man's activities in the Kootenai Drainage, however, are additional threats to juvenile recruitment and food production. If present trends continue, it is likely that the cumulative effects will result in damage to this valuable inland fishery. A comprehensive approach by cooperating land management agencies is needed to assess the extent of present environmental problems and to determine methods for eliminating harmful contributing factors. 



\section{LITERATURE CITED}

Allendorf, F.W. and S. Phelps. 1980. Coexistence of native and introduced rainiow trout in the Kootenai River Drainage. Proceedings of the Montana Academy of Science 39:28-36.

Bonde, J.H. and R.M. Bush. 1982. Limnological investigations: Lake Roocanusa, Montana Part 1: Pre-impoundment study 19671972. U.S. Army Corps of Engineers, Seattle District, Special Report 82-21.

Eraley, J.J., M.A. Gaub, and J.R. Cavigli. 1986. Emergence trap and holding bottle for the capture of salmonid fry in streams. North American Journal of Fisheries Management 6(1):119-121.

Huston, J.E., P. Hamlin, and B. May. 1984. Lake Koocanusa fisheries investigation. Final completion report to the U.S. Army Corps of Engineers, Seattle District, by the Montana Department of Fish, Wildlife and Parks, Kalispell, Montana.

Leathe, S., and F. Nelson. 1986. A literature evaluation of Montana's wetted perimeter inflection point method for determining instream flow recommendations. Montana Department of Fish, Wildlife and Parks, Helena, Montana.

May, B. and J.E. Huston. 1983. Section C. Fisheries investigations July 1972 - September 1982. In Kootenai River Fisheries Investigations. Final completion report to the U.S. Army Corps of Engineers, Seattle District, by Montana Department of Fish, Wildlife and Parks, Kalispell, Montana.

May, B., R. Schumacher and J.E. Huston. 1983. Section D. Kootenai River management objectives. In Kootenai River fisheries investigations. Final completion report to the U.S. Army Corps of Engineers, Seattle District, by the Montana Department of Fish, Wildlife and Parks, Kalispell, Montana.

May, B. 1982. Instream flow evaluation for selected streams in the Kootenai National Forest. U.S. Forest Service Contract No. 53-0343-0-305. Montana Department of Fish, Wildlife and Parks, Kalispel1, Montana.

May, B. and J.E. Huston. 1980. Lake Koocanusa post-impoundment fishery study. Annual progress report. Contract DACW 67-79C-0007. Montana Department of Fish, Wildlife and Parks, Kalispel1, Montana.

May, B. 1972. Evaluation of mitigation measures in Fisher River, Wolf Creek and Fortine Creek - 1969-1972. Montana Fish and Game Report. U.S. Army Corps of Engineers Contract No. DACW 67-70-C-0001. Montana Department of Fish and Game, Kalispell, Montana. 
Nelson, F.A. 1980. Evaluation of four instream flow methods applied to four trout rivers in southwest Montana. Montana Department of Fish, Wildlife and Parks report to USFWS. Contract No. 14-16-0006-78-046. 105 pp.

Parrett, C. and J.A. Hull. 1985. Streamflow characteristics of mountain streams in western Montana. U.S. Geological Survey. Water-Supply paper 2260. 58 pp.

Peters, J.C. 1962. The effects of stream sedimentation on trout embryo survival. In Biological Problems in Water Pollution, Third Seminar, 1962, pp 275-279. Public Health Service Publication 999-WP-25.

Ricker, W.E. 1975. Computation and interpretation of biological statistics of fish populations. Bulletin 191 Fishery Research Board of Canada. Ottawa, Canada. $382 \mathrm{p}$.

Seber, G.A.F. 1973. The estimation of animal abundance and related parameters. Griffin Press, London.

Shepard, B.B., J.J. Fraley, T.M. Weaver, and P. Graham. 1982. Flathead River Fisheries Study - 1982. Montana Department of Fish, Wildlife and Parks, Kalispell, Montana.

Wesche, T.A. and P.A Rechard. 1980. A summary of instream flow methods for fisheries and related research needs. Eisenhower Consortium Bulletin 9. 122 p.

U.S. Geological Survey 1973-1985. Water resources data, water year 1974-1984. U.S. Geological Survey, water-data reports MT-73-1 through MT-84-2. U.S. Geological Survey, Water Resources Division, 301 S. Park Avenue, Drawer 10076. Federal Office Building, Room 428, Helena, Montana 59626.

U.S. Soil Conservation Service. 1977. Average annual precipitation, Montana. Based on 1941-1970 base period. U.S. Soil Conservation Service Publication, P.O. Box 970, Bozeman, Montana. 
APPENDIX A 


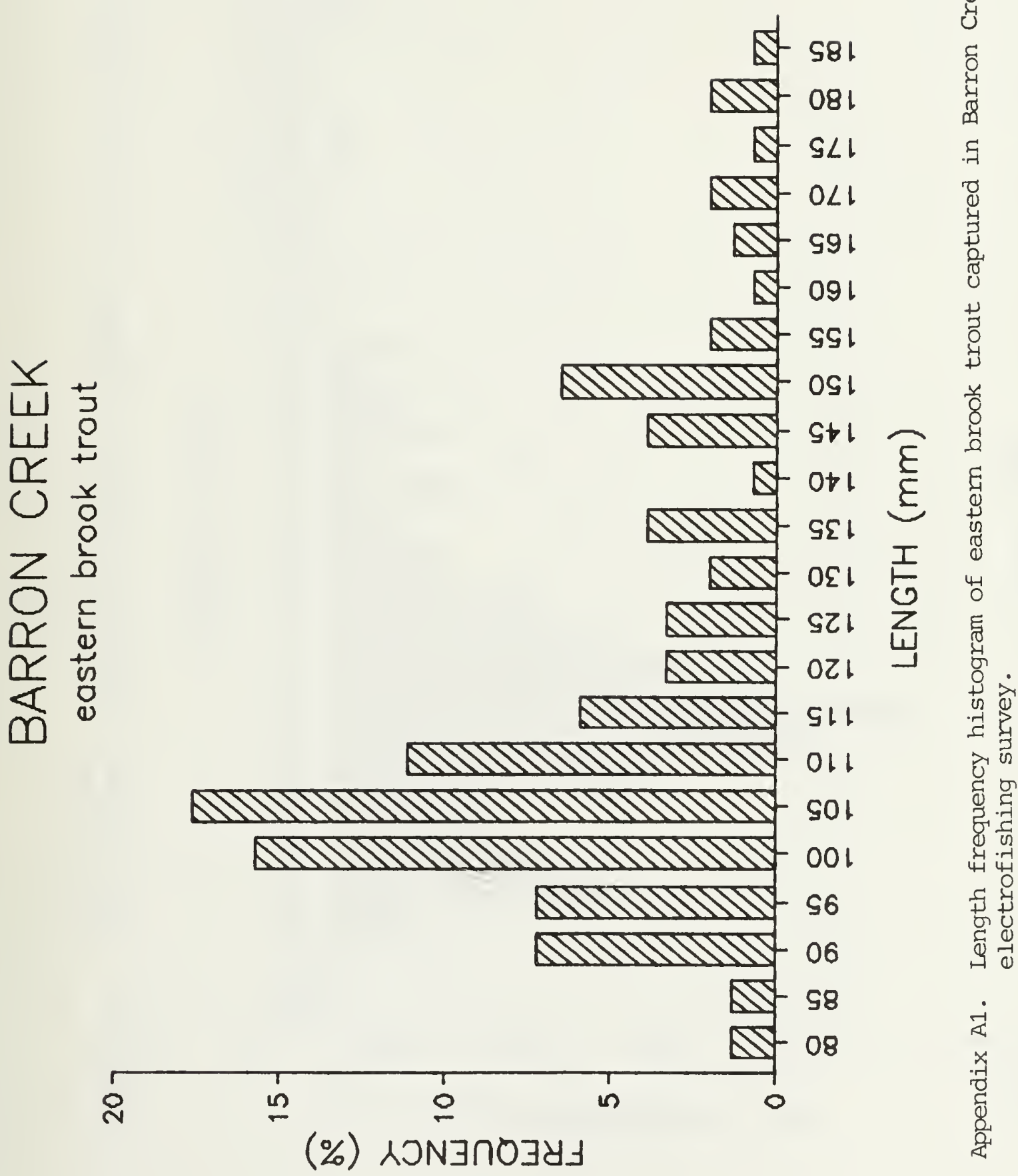


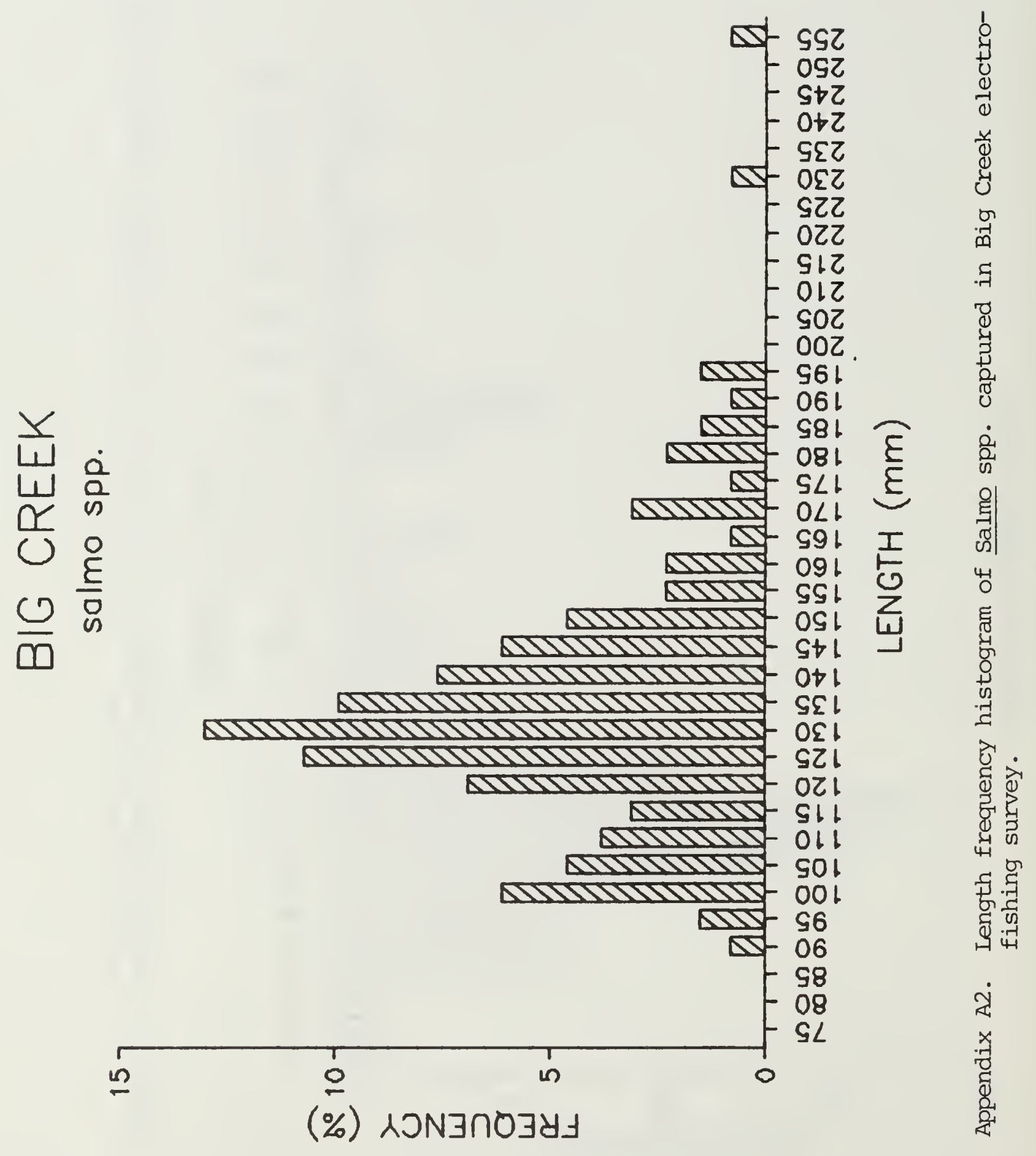


$\sum_{\alpha}^{0}$

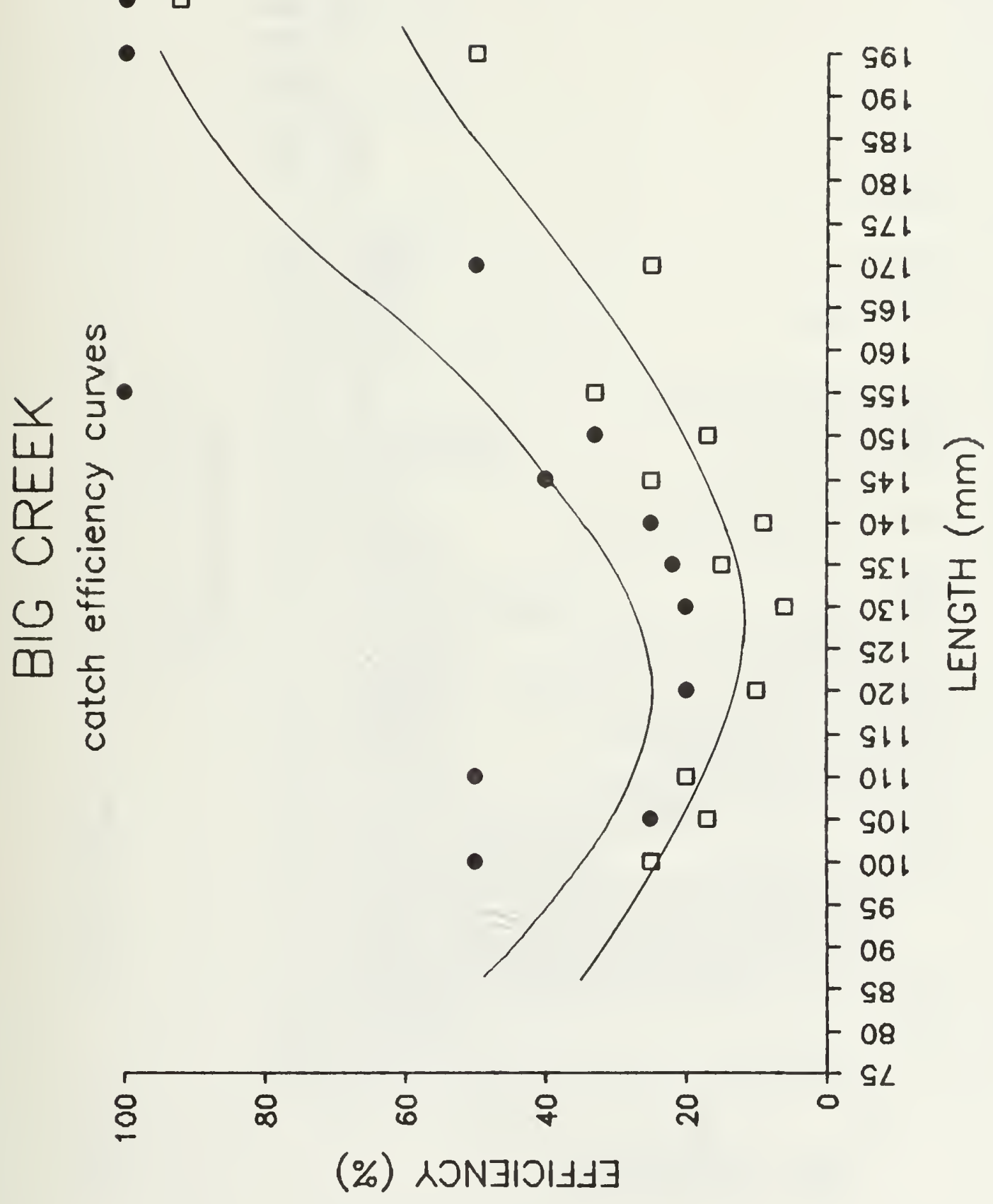

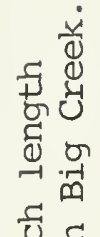

ग्ण

다 $\frac{0}{\varrho}$

过 U

م

Uू

4

동요

ठ

on

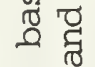

菅国

이

急

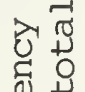

,

당

出

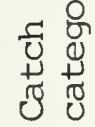

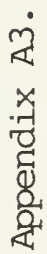



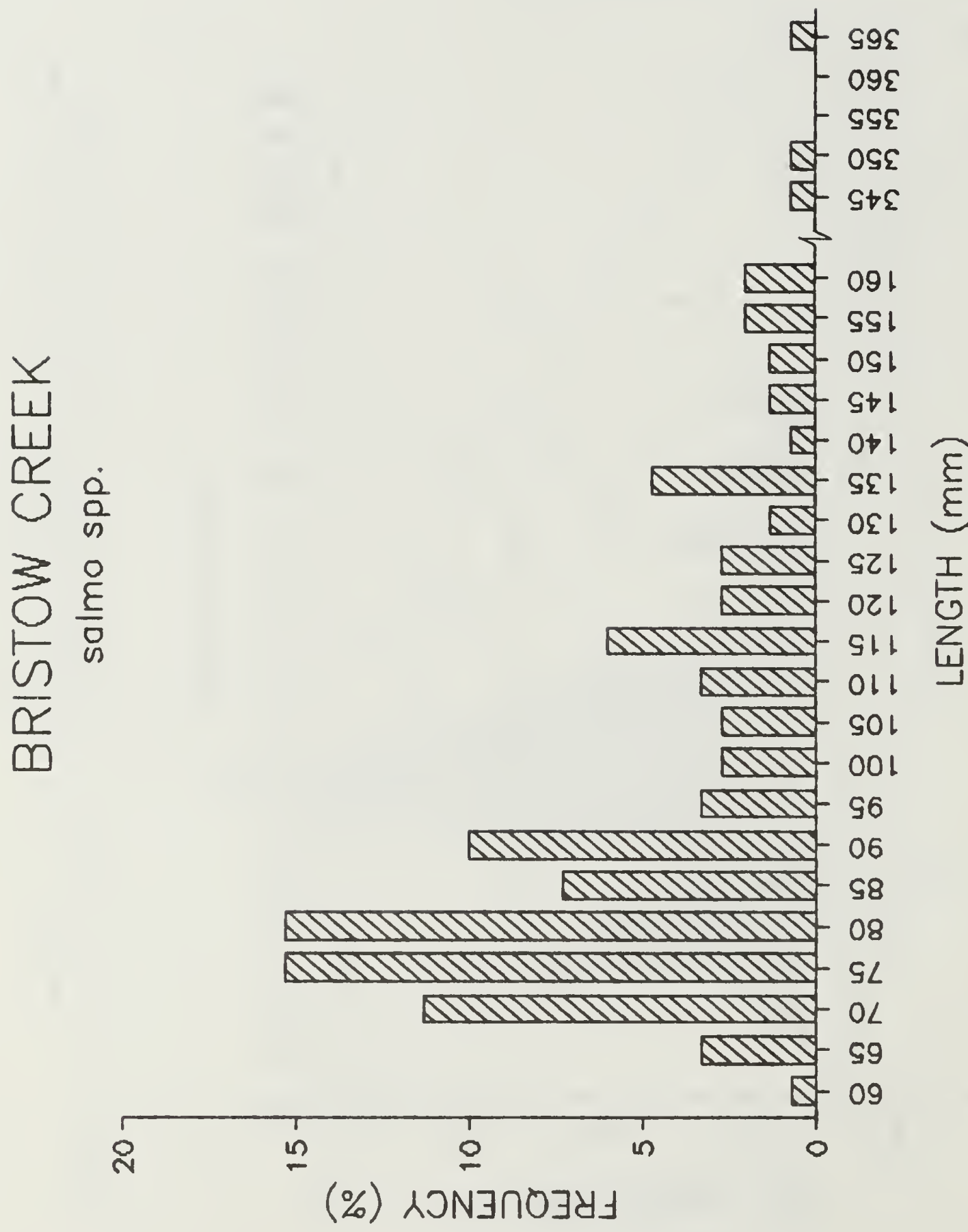


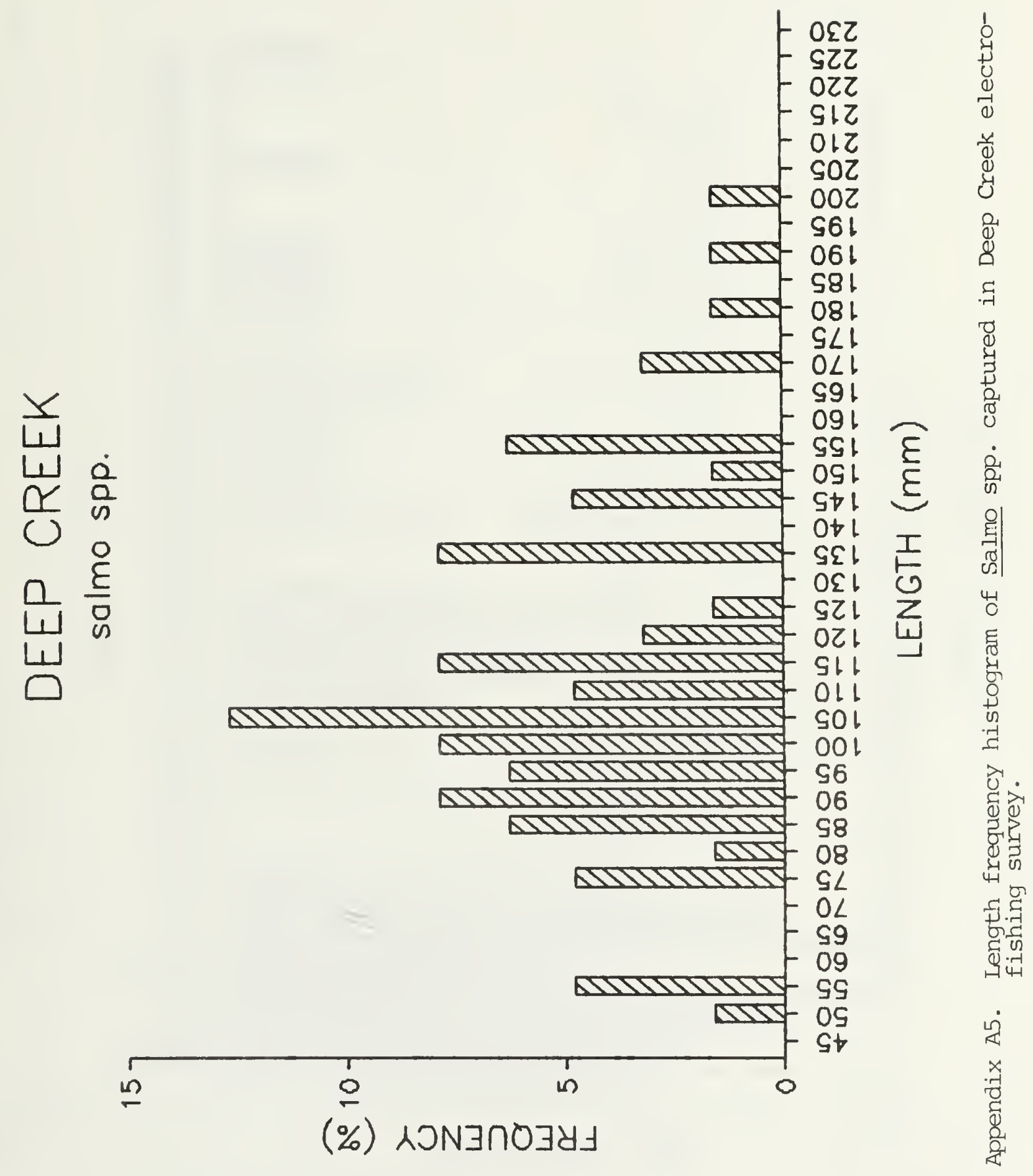




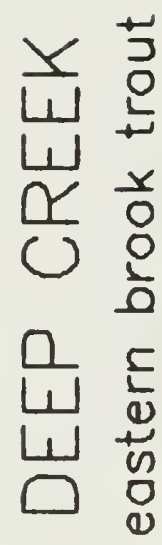

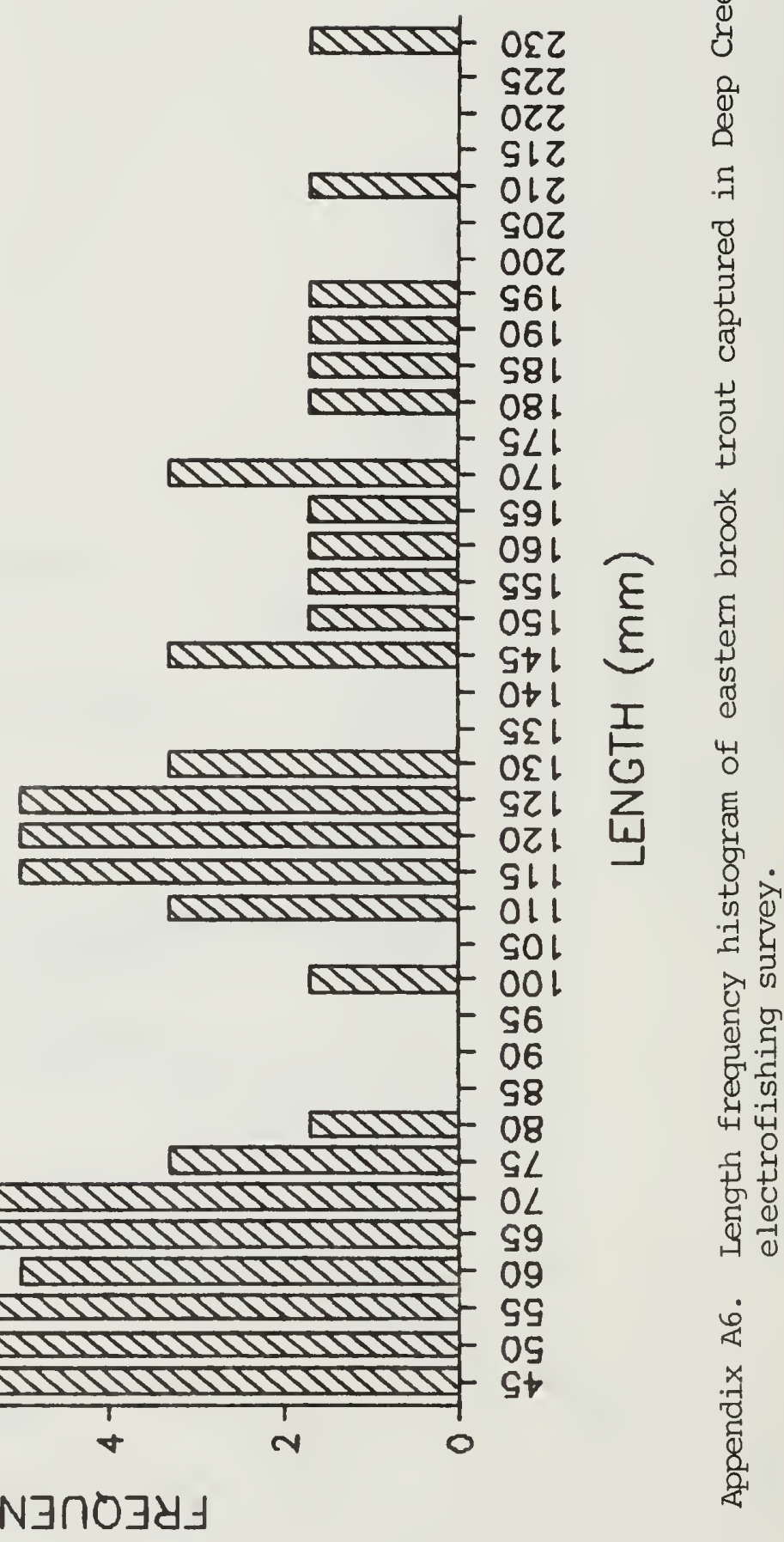




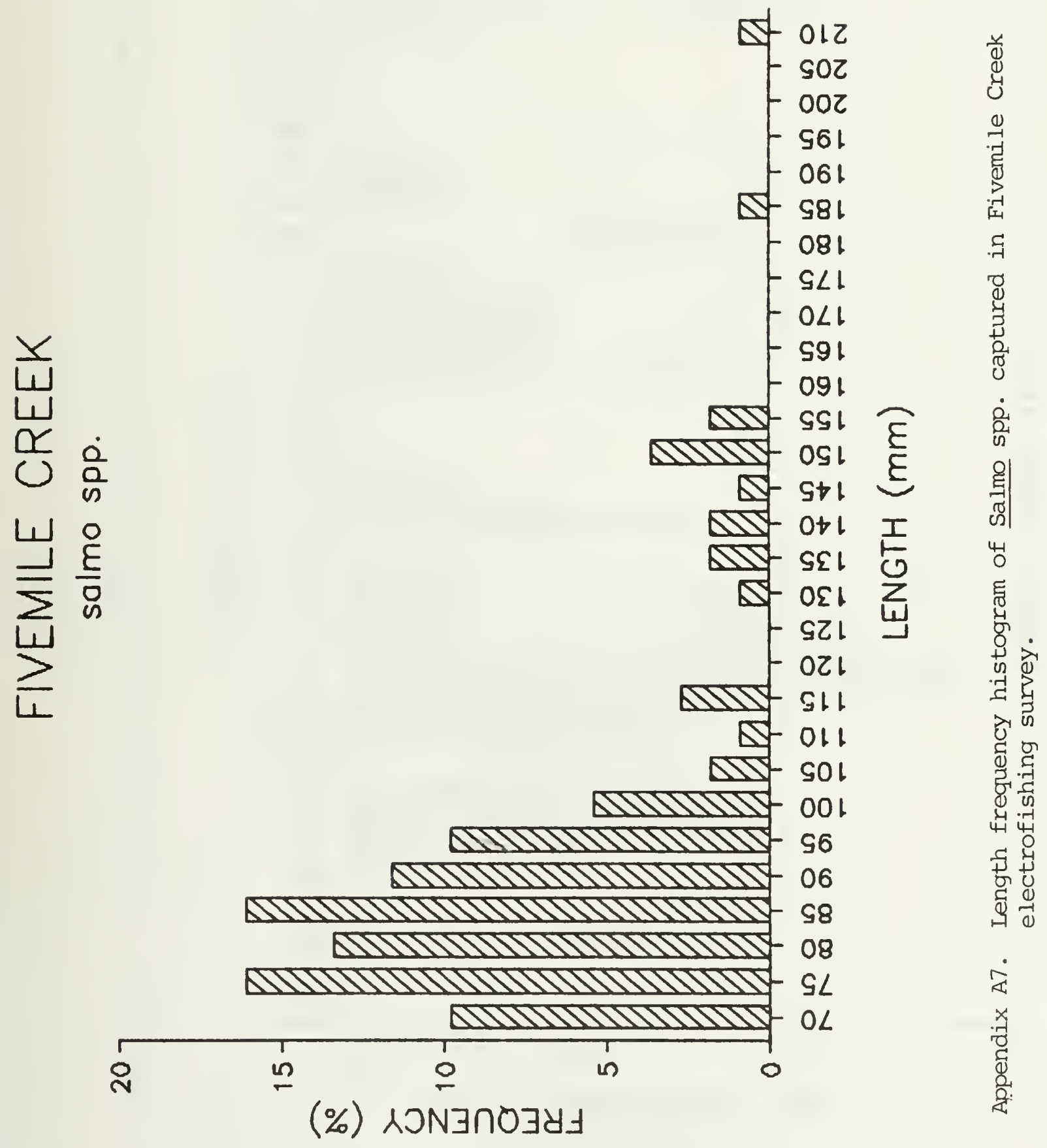



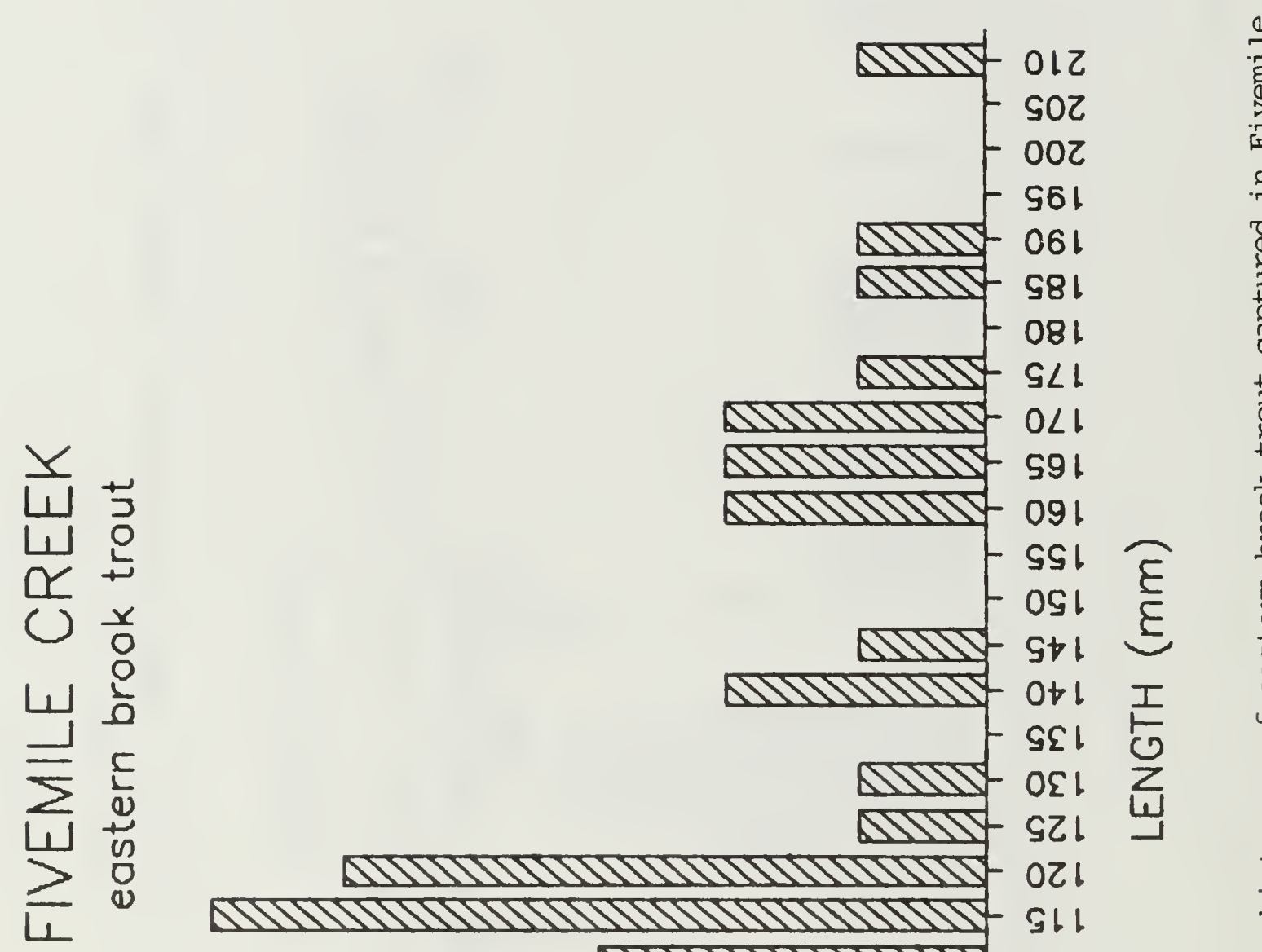

SWJ $\mathrm{S} L \mathrm{l}$

DWWJWJ- $0<1$
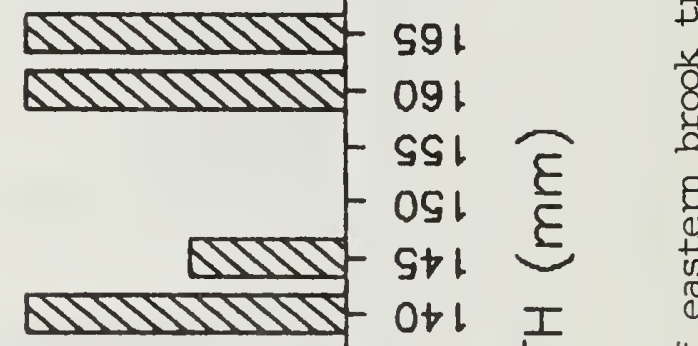

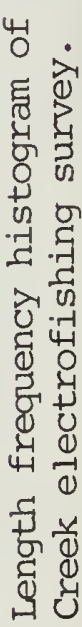

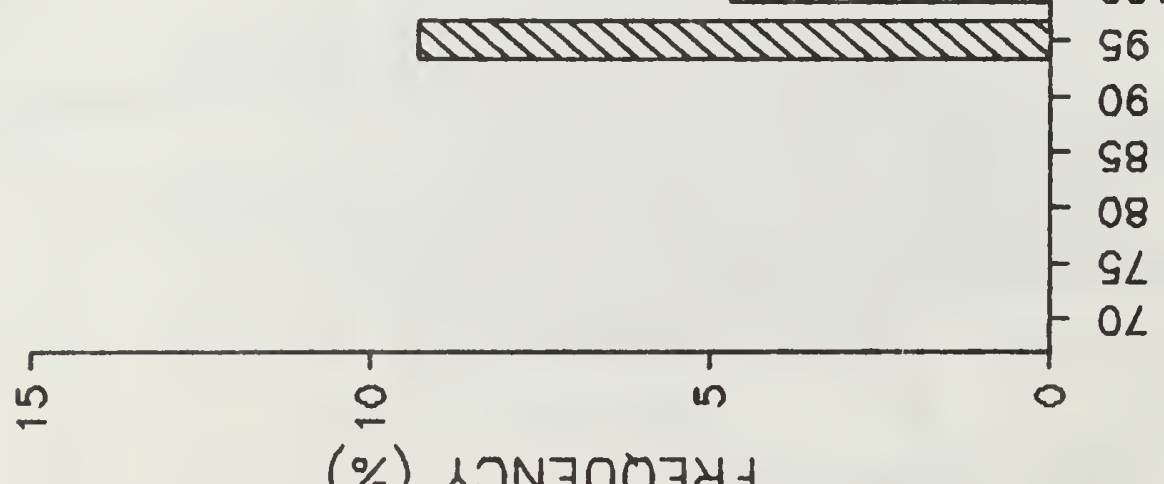

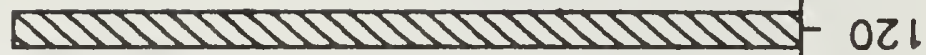

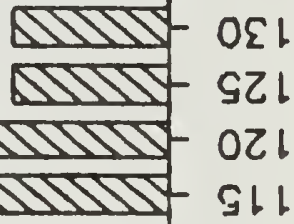

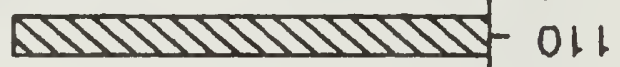

- sol

DIJIJIJ 001

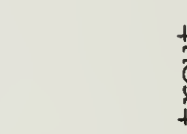



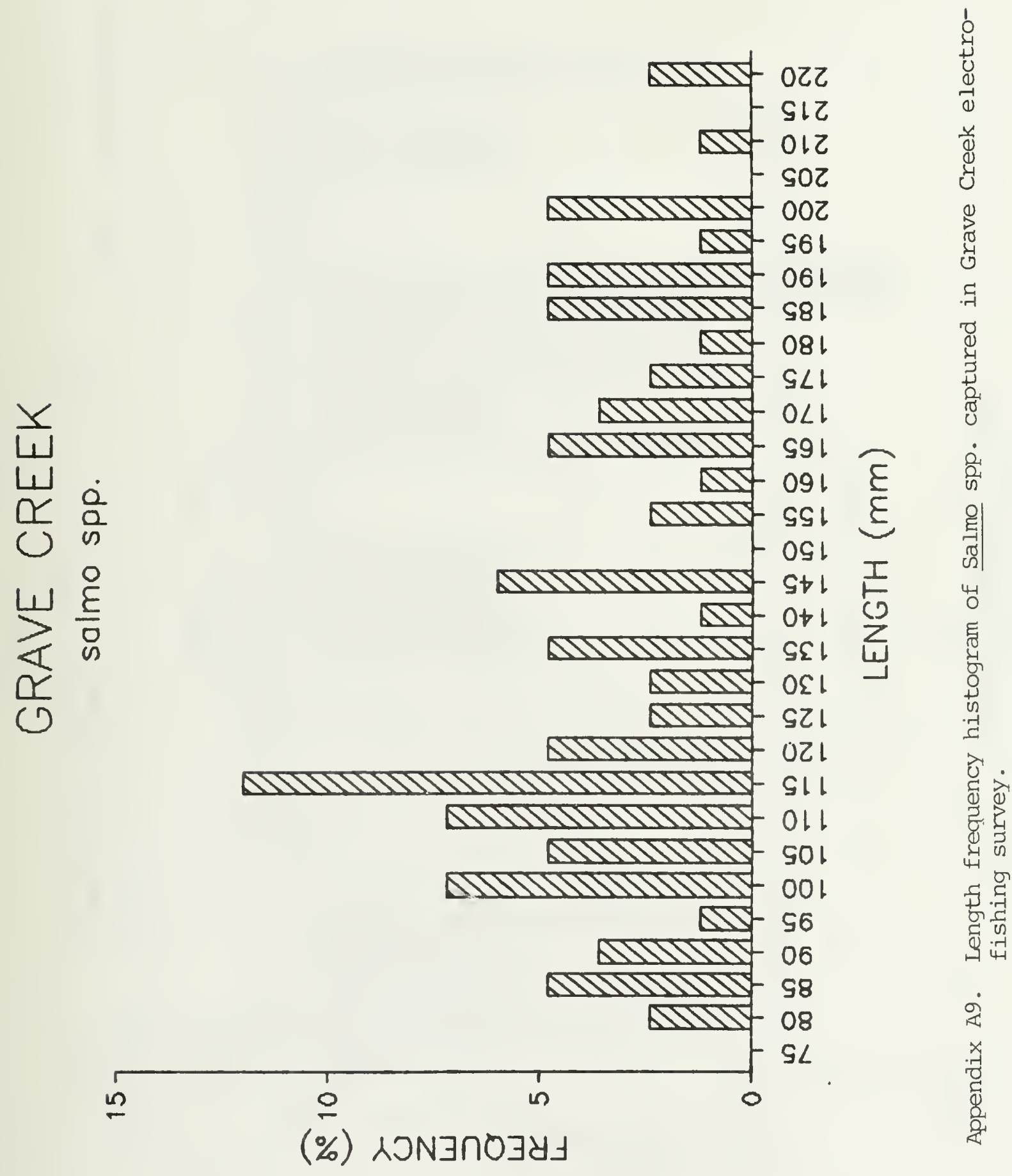


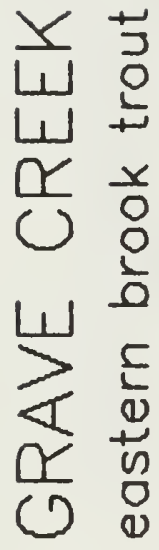

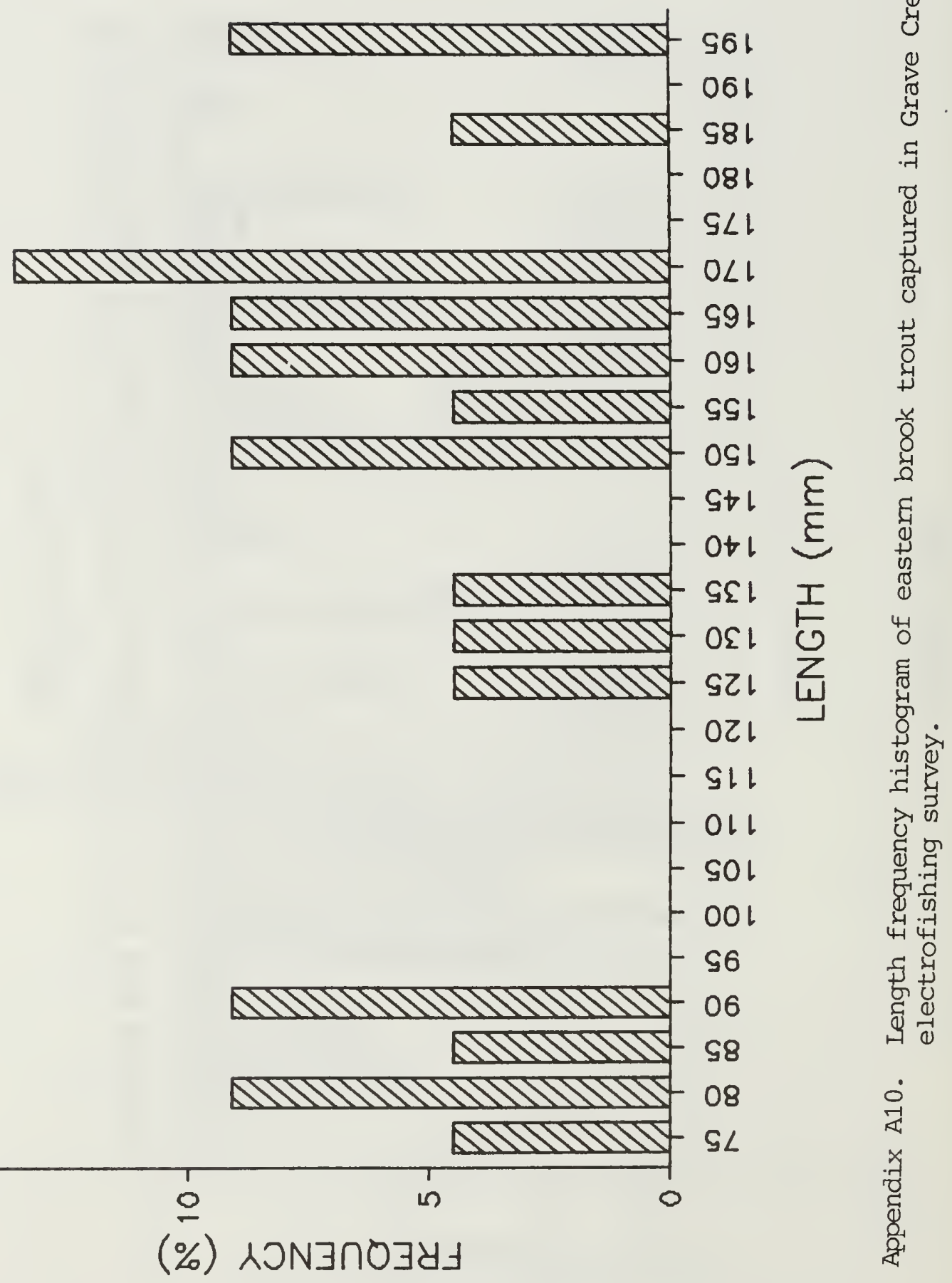




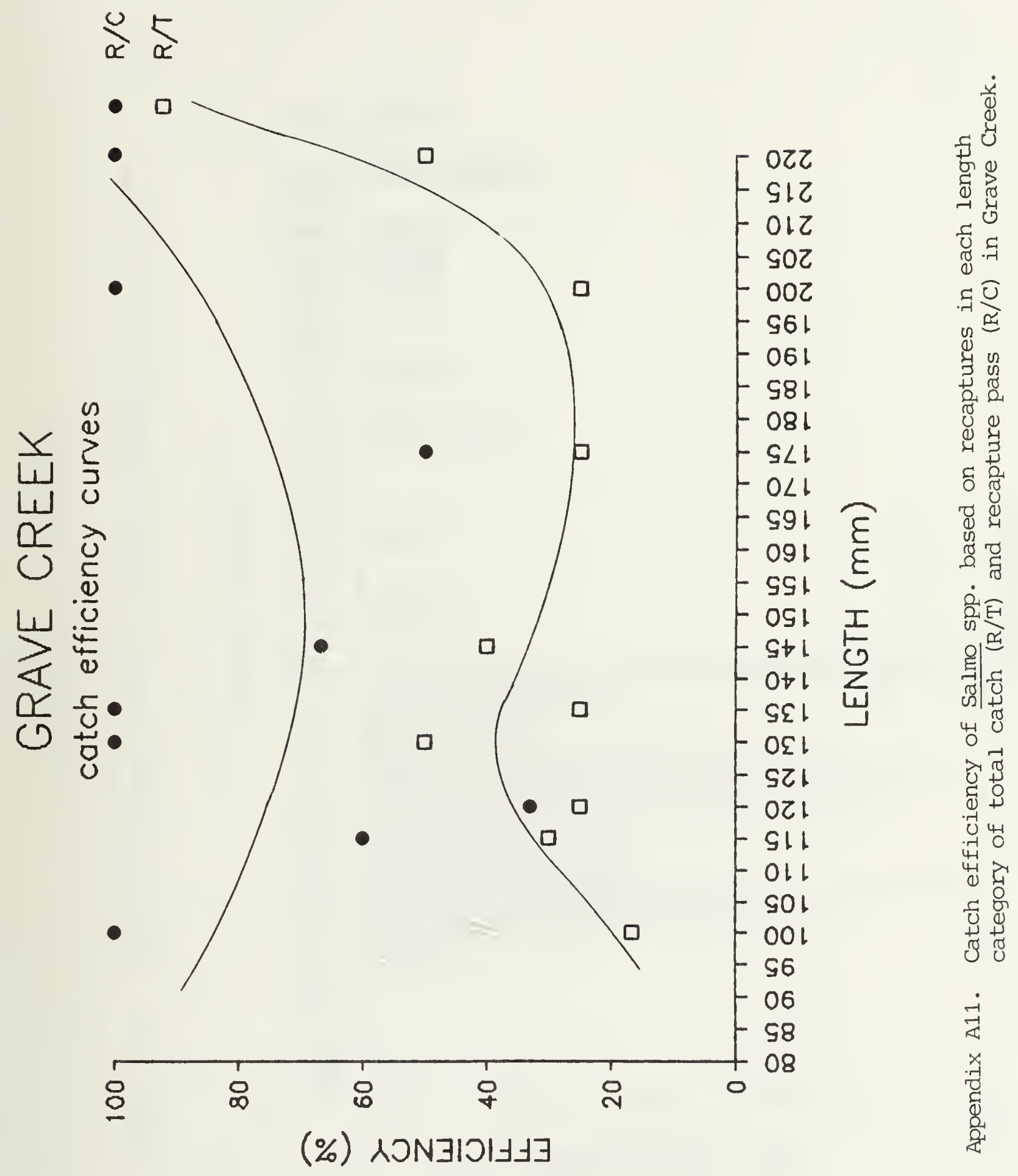



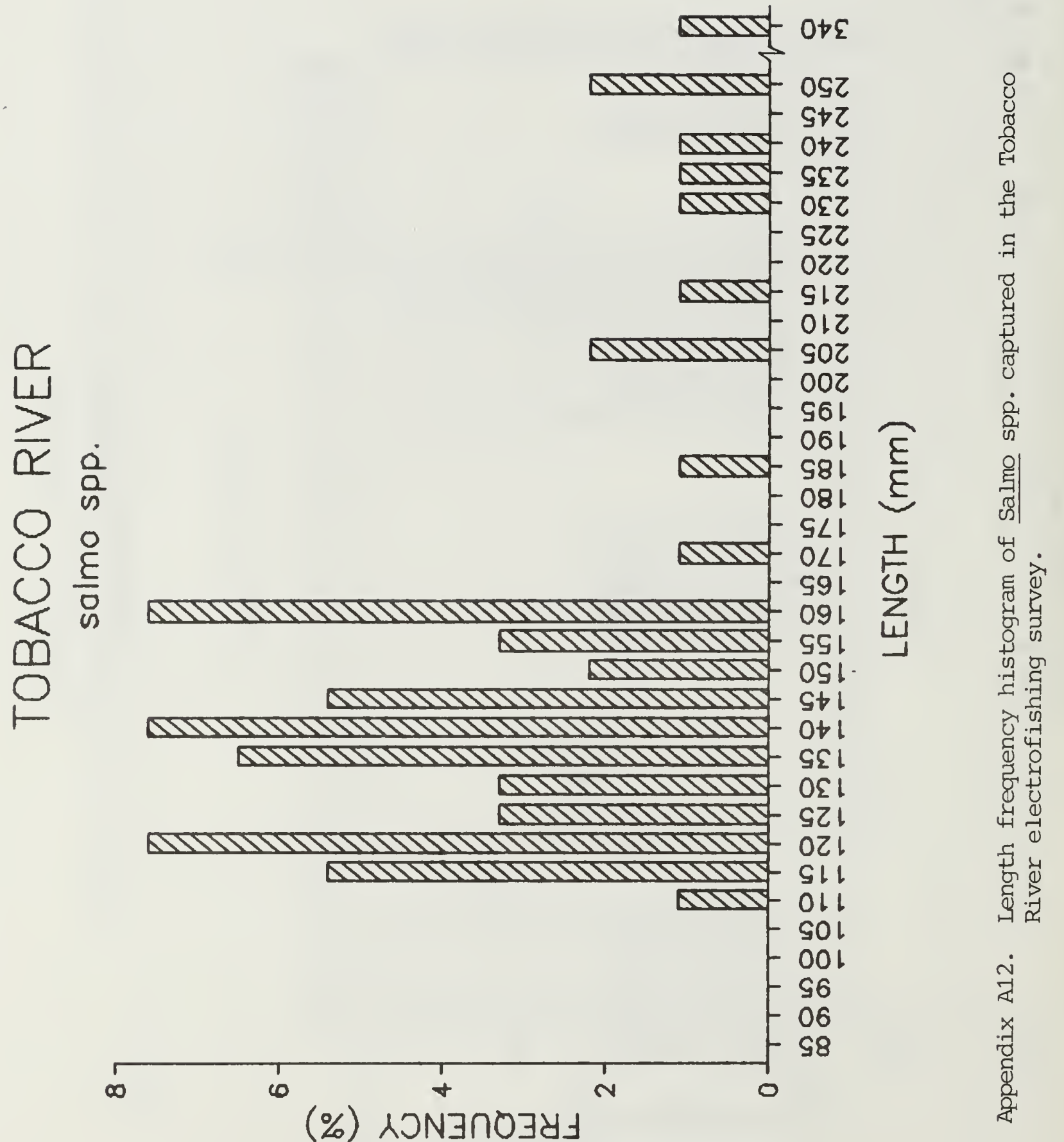


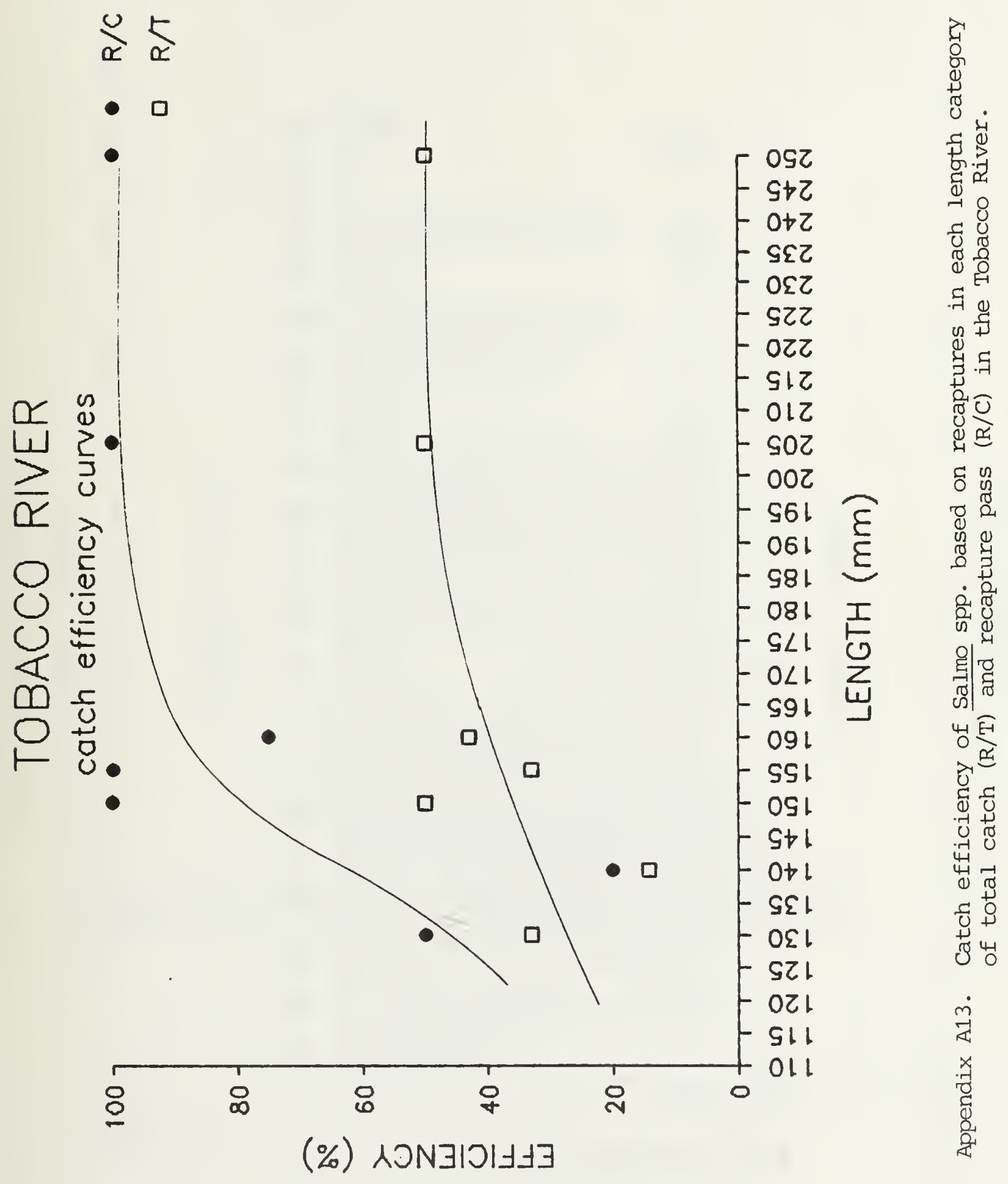



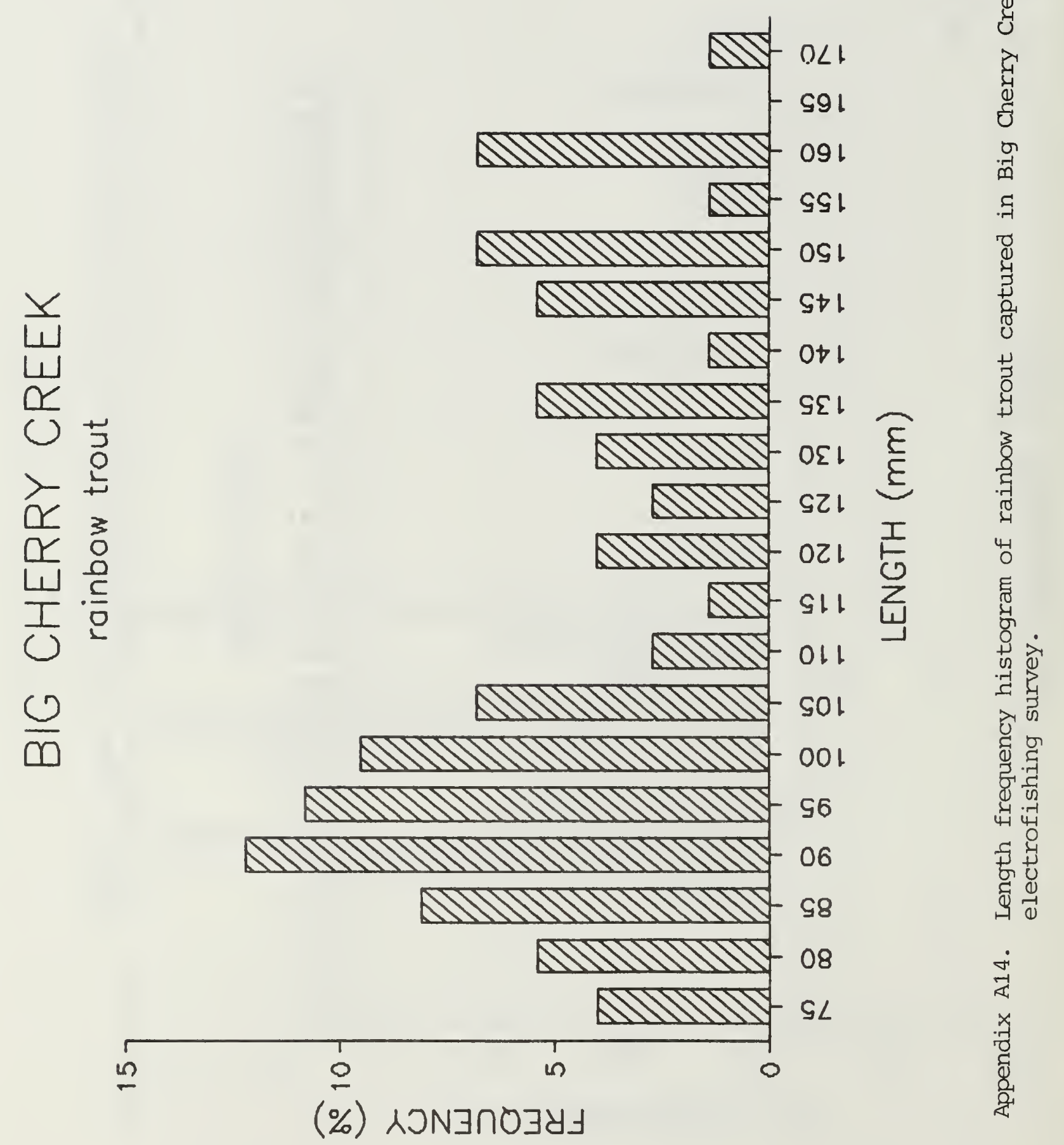


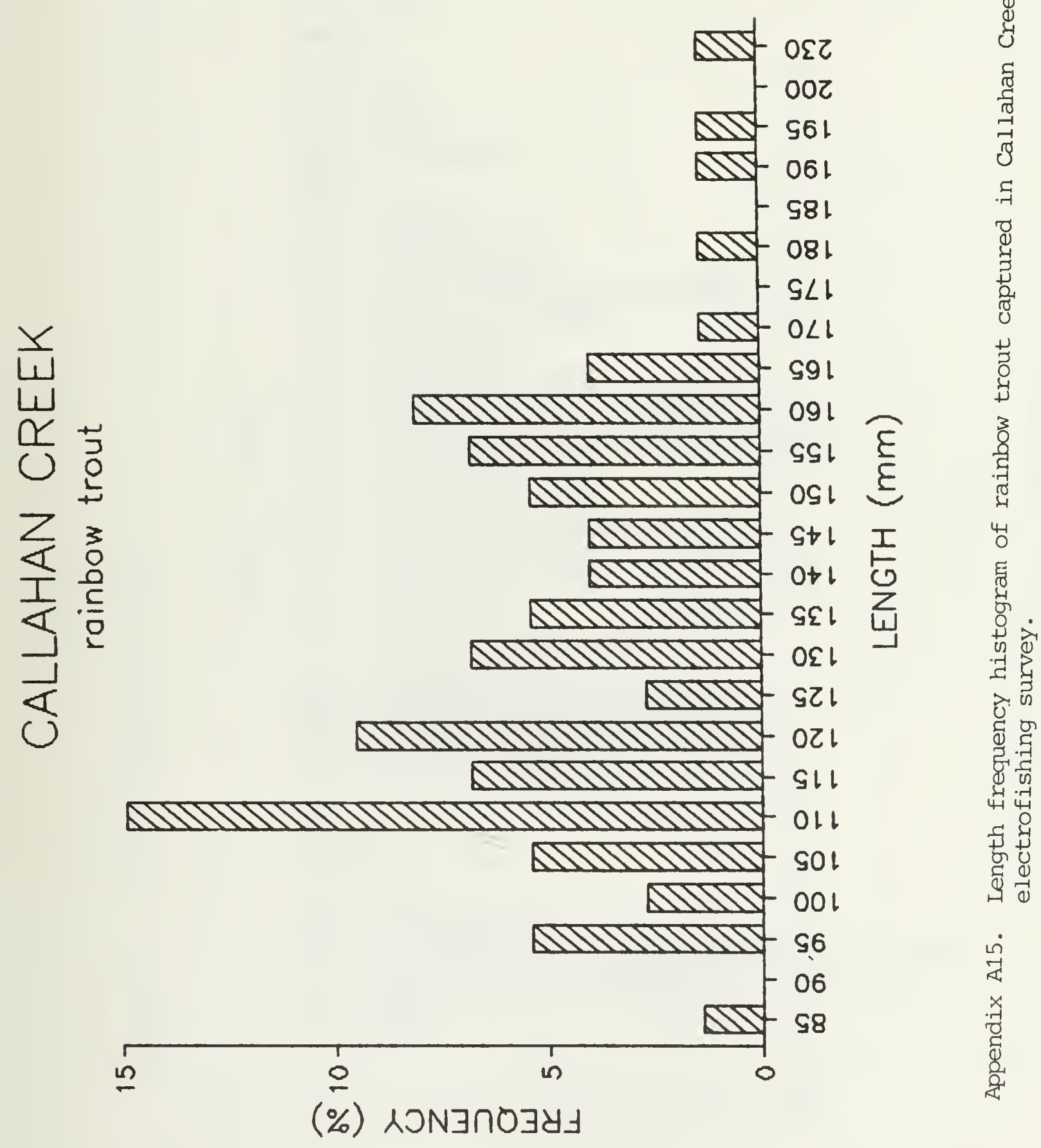



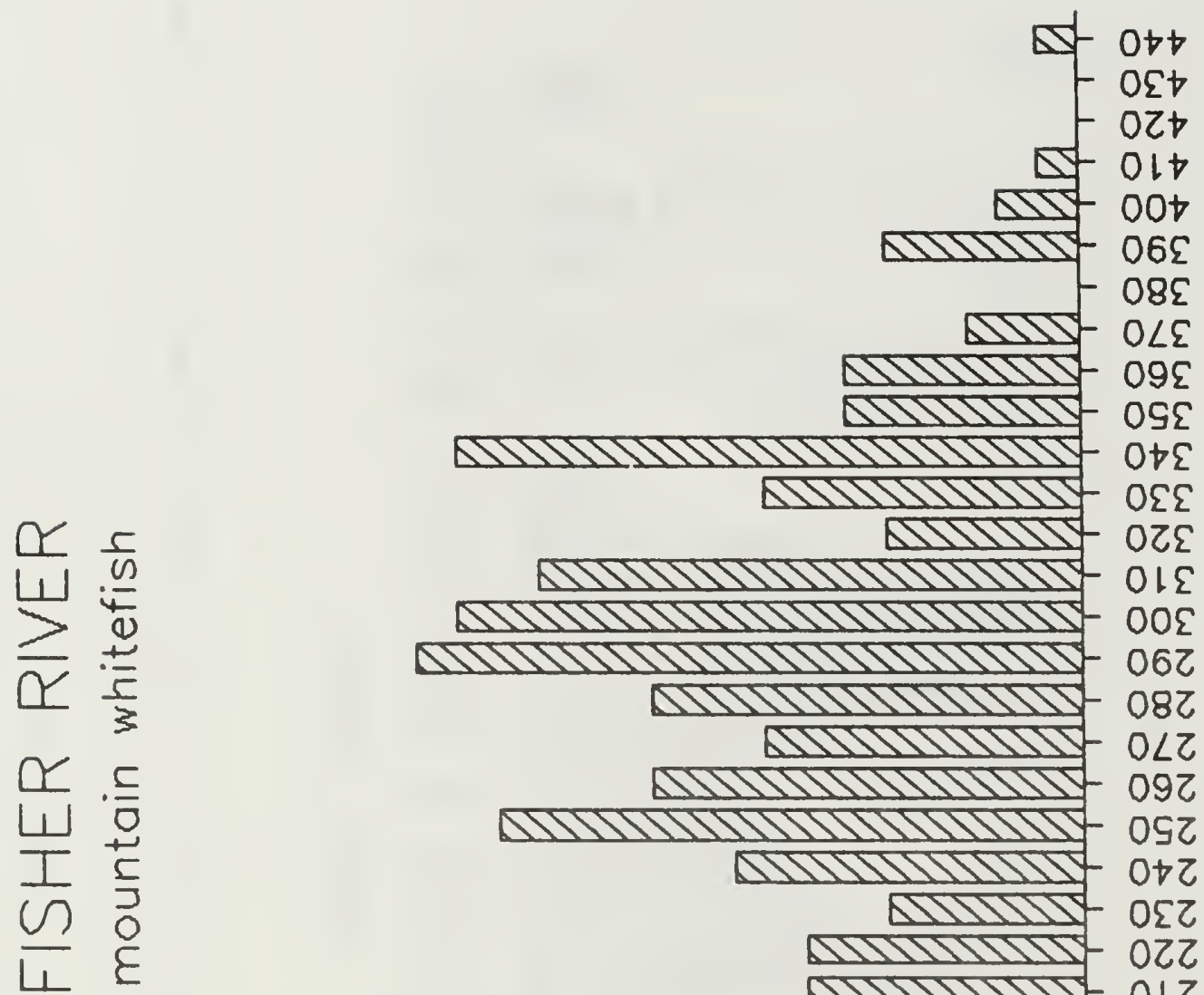

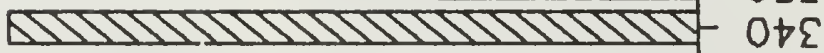

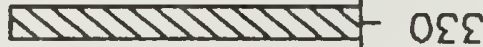
ब1WW1 OZE

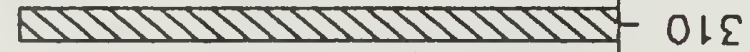

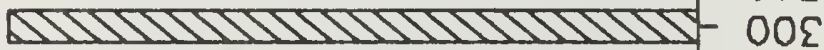

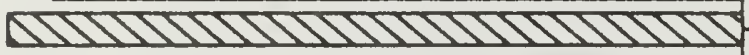

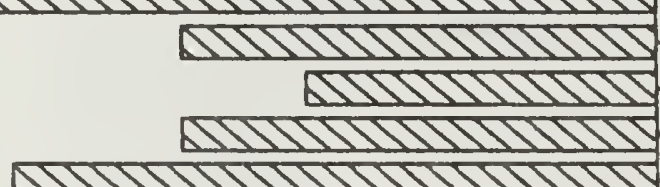

1117) \$111111111

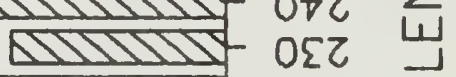

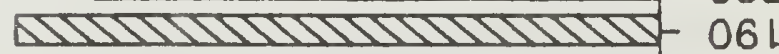

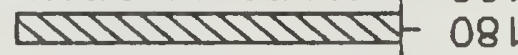
ब1111115- $0<1$ 091

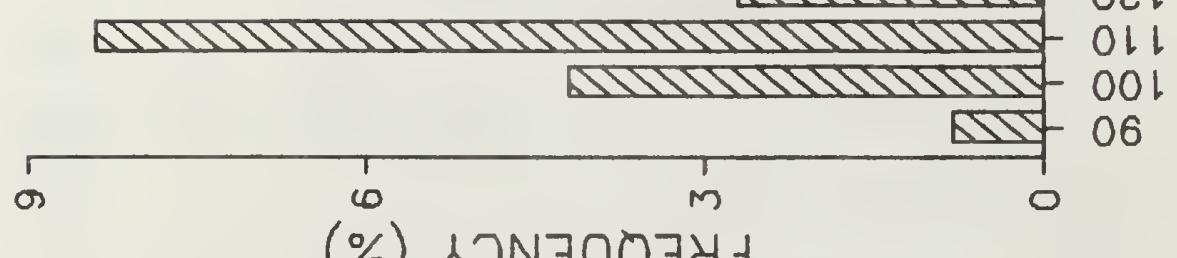



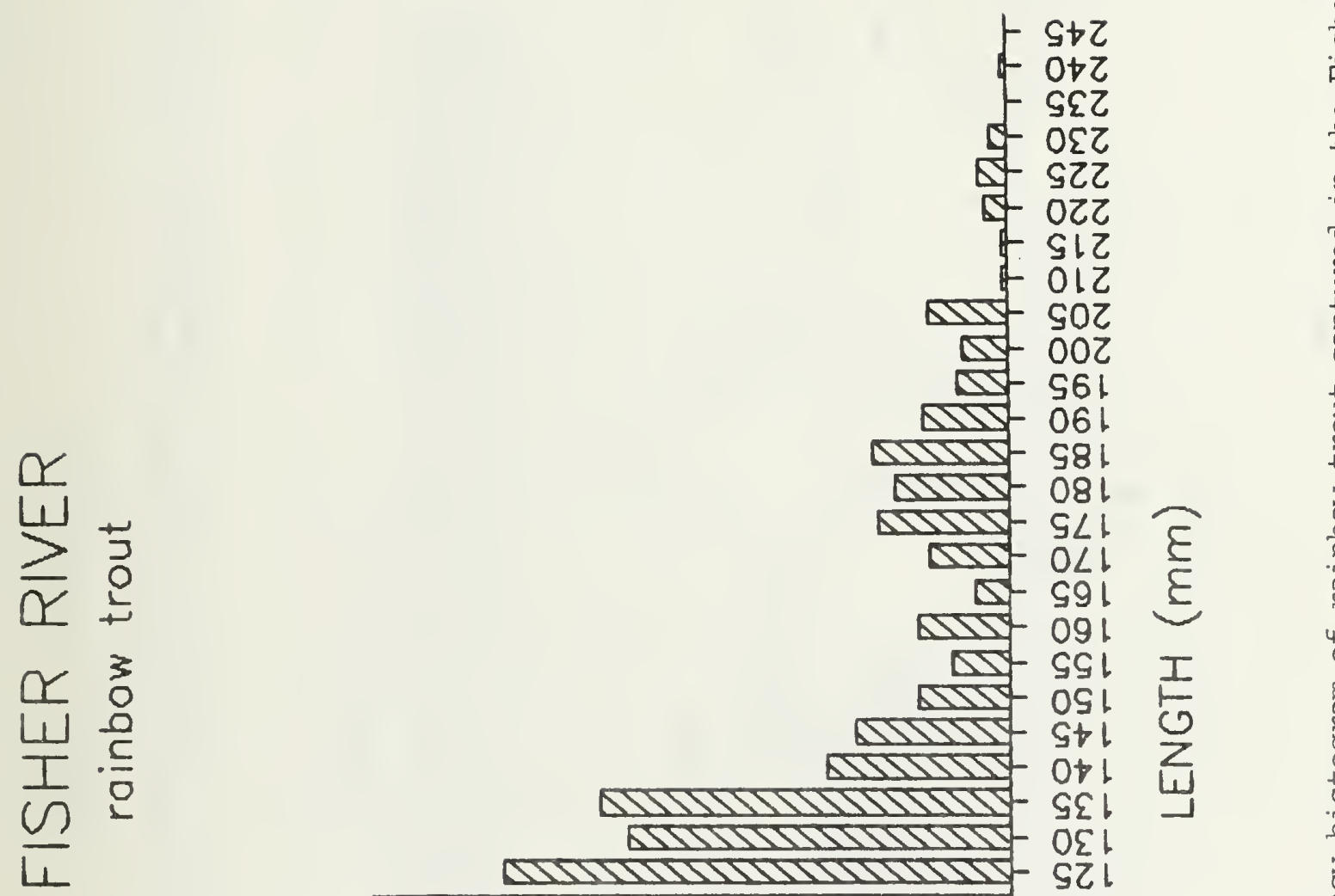

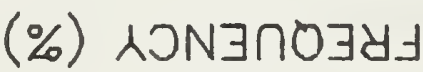


ํㅜㄹ

- $\square$
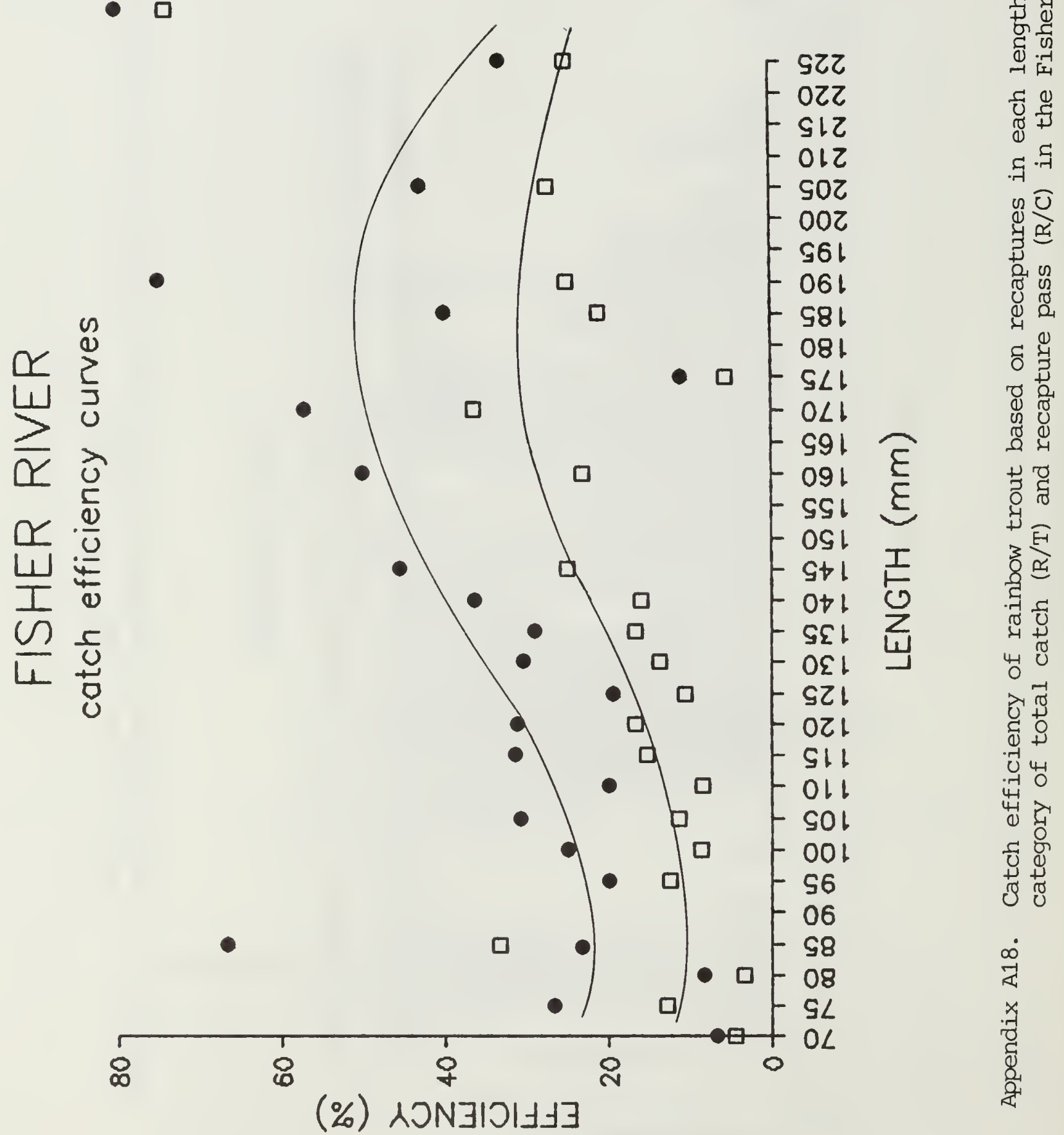

F) 

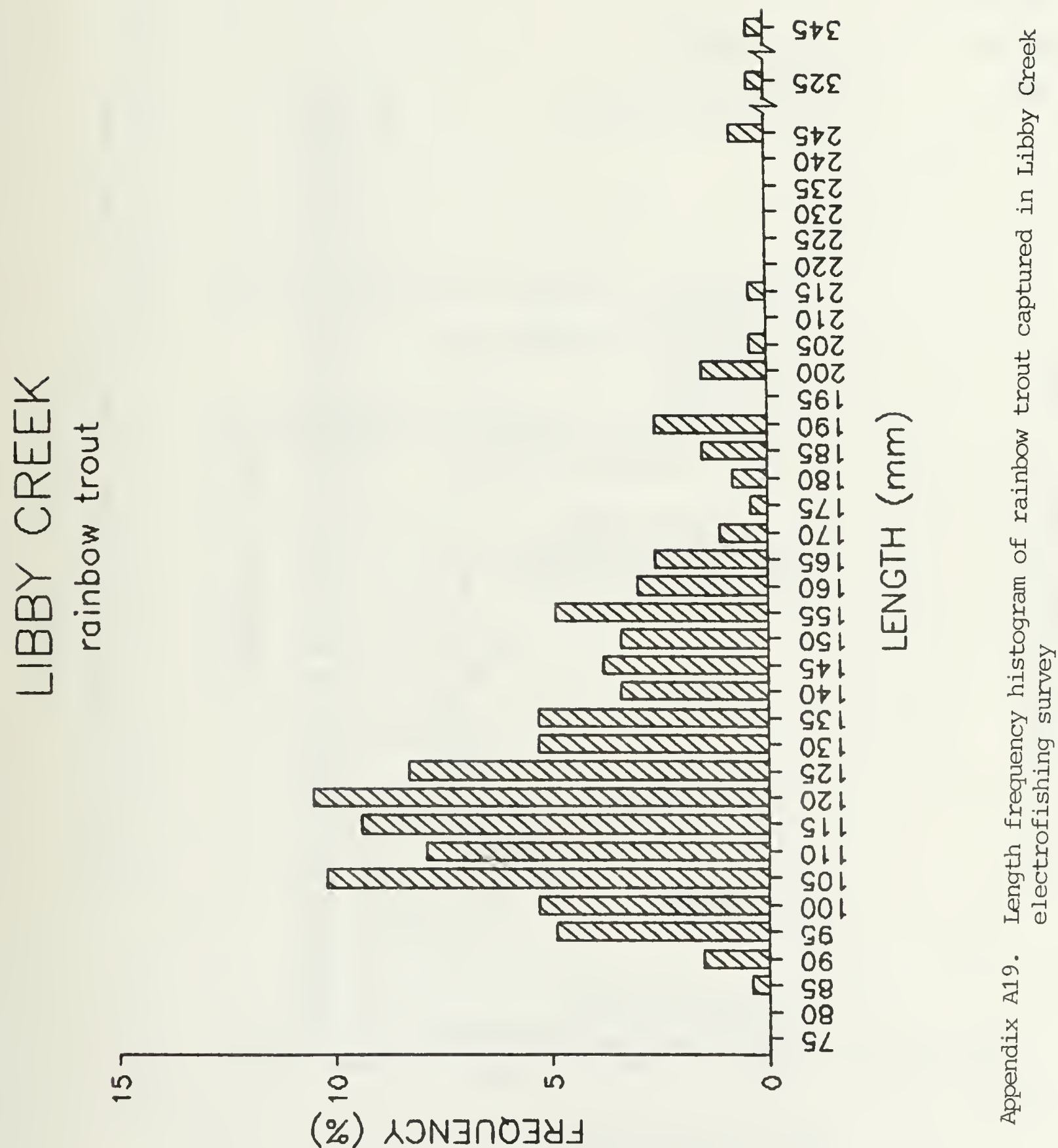
$\sum_{\alpha}^{0} 5$

్ㅐ
0
0
0
0
0

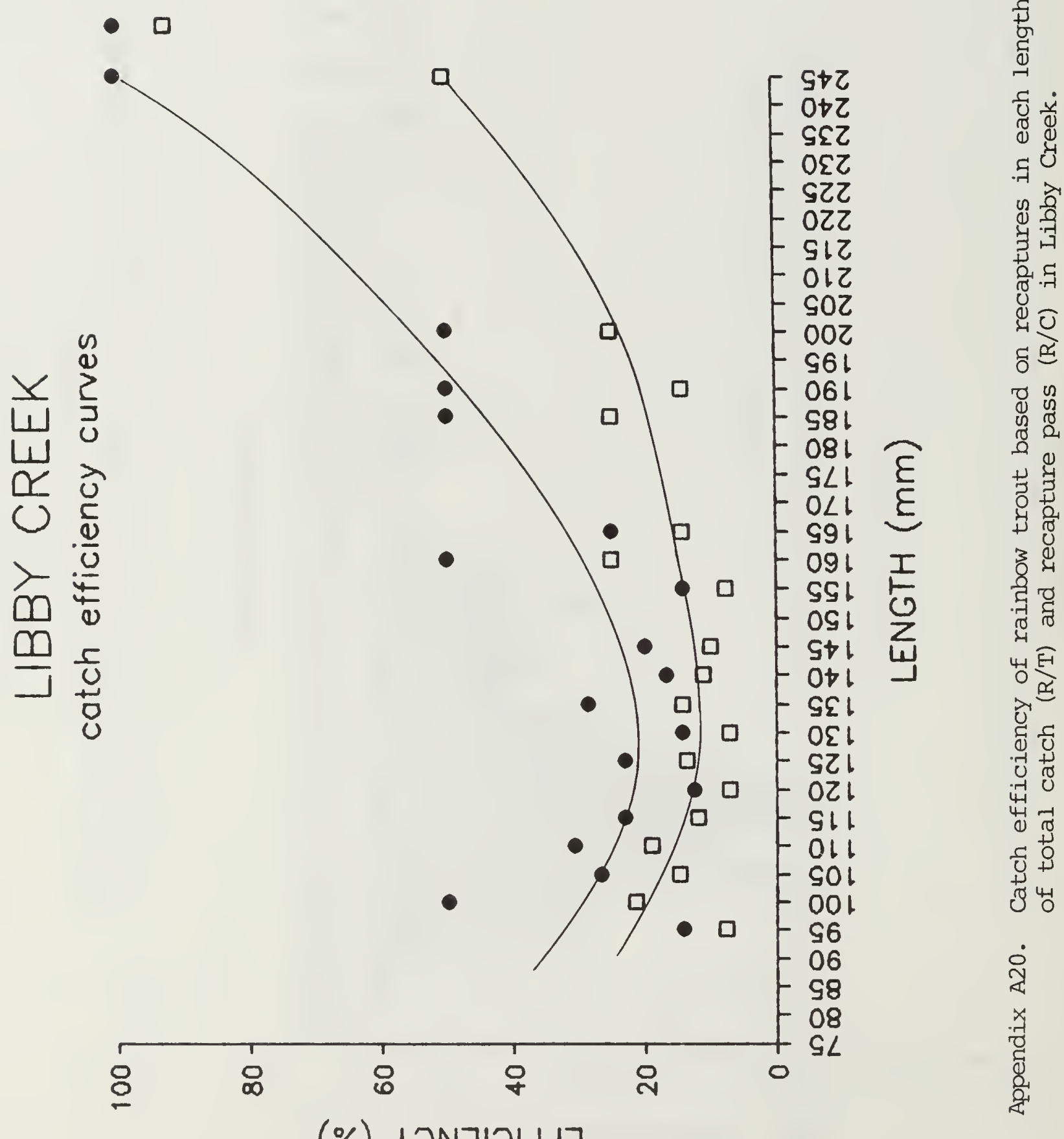



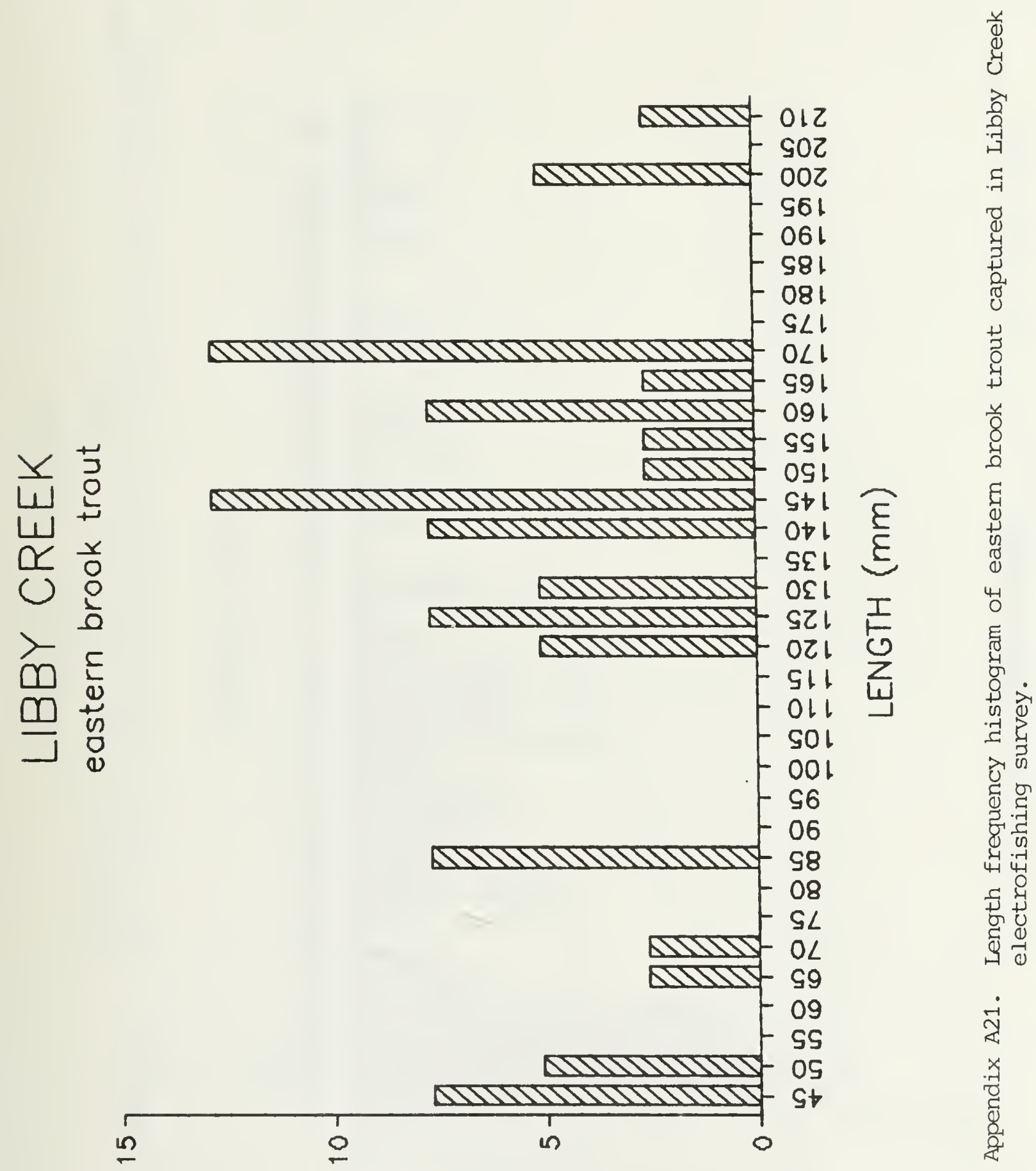

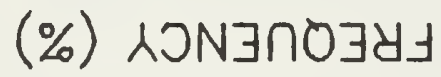




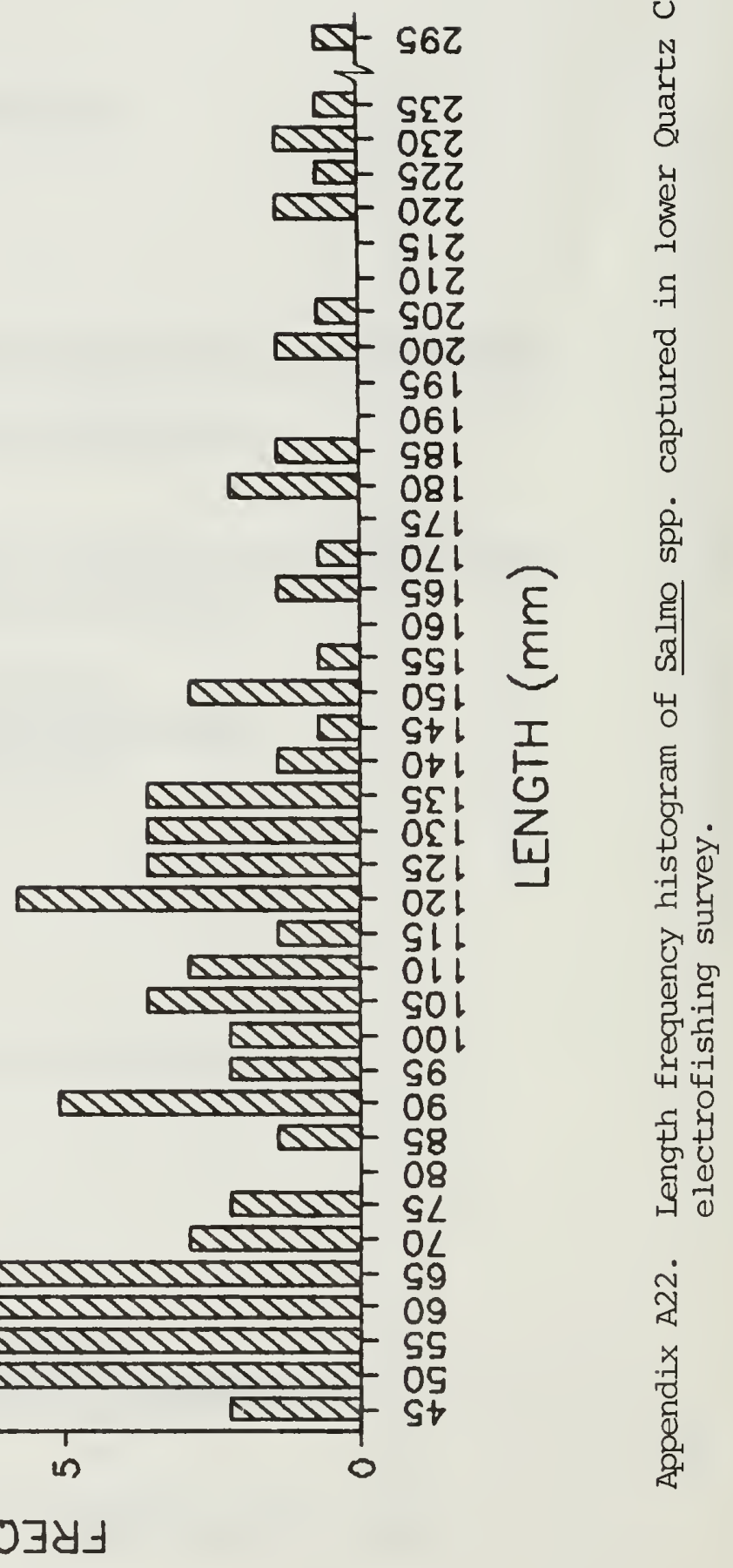

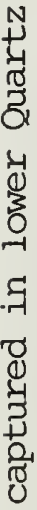

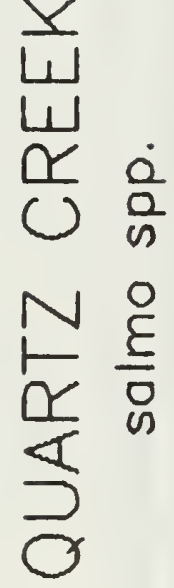




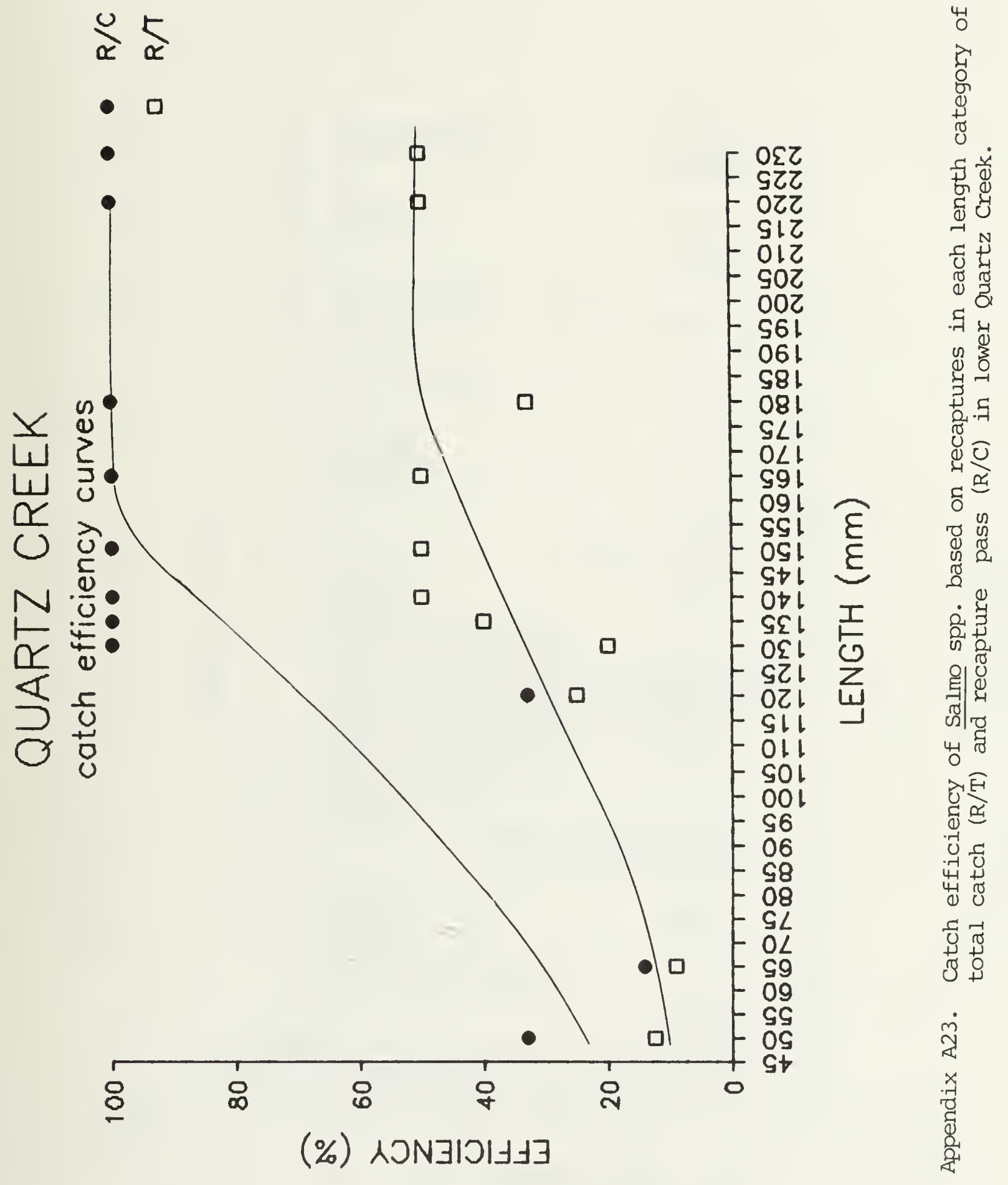



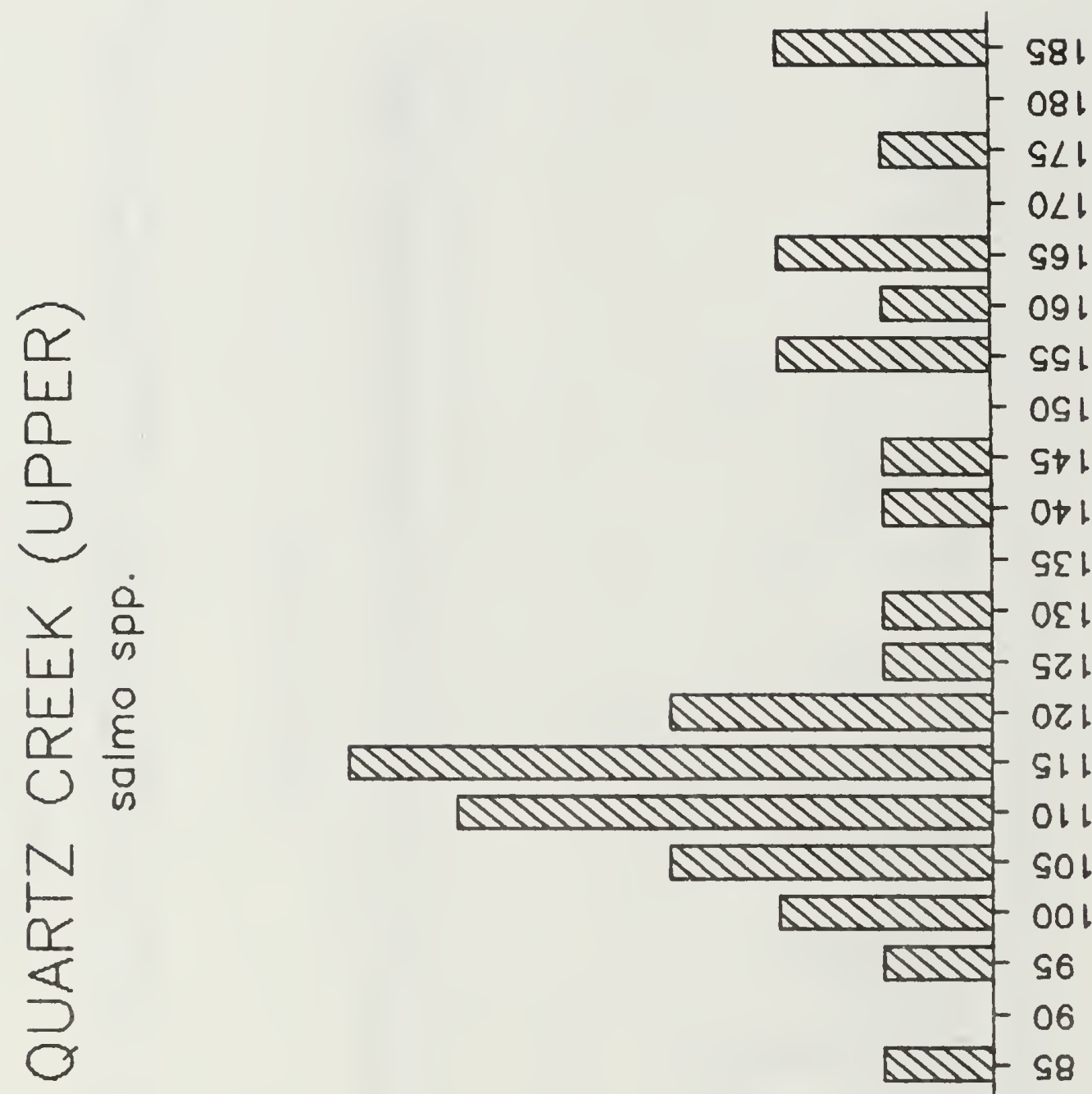

$$
\begin{aligned}
& \frac{0}{0} \\
& \text { n } \\
& \frac{0}{0} \\
& \text { n }
\end{aligned}
$$

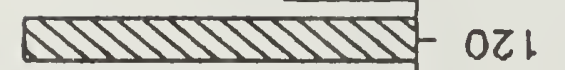
WIIIIJIIIIIIIJIJ-

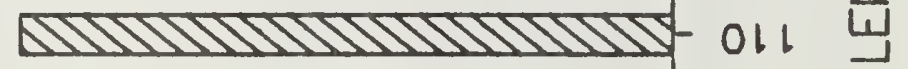

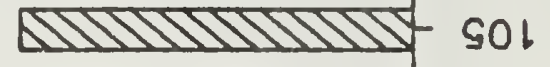
I 过 点 DIIIJIS 001 जIIt 96

- 06

DIII 98 DIJ- 08
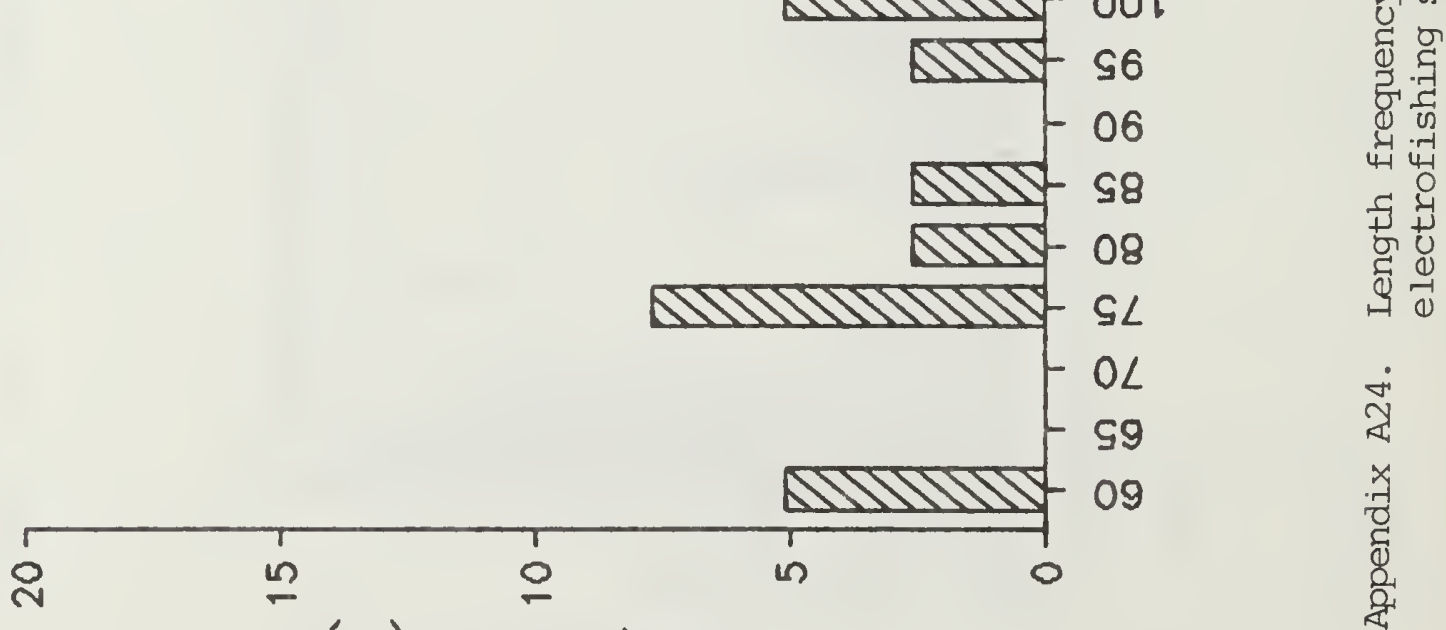

(\%) $\wedge$ ก $\exists \cap O \exists y$ 

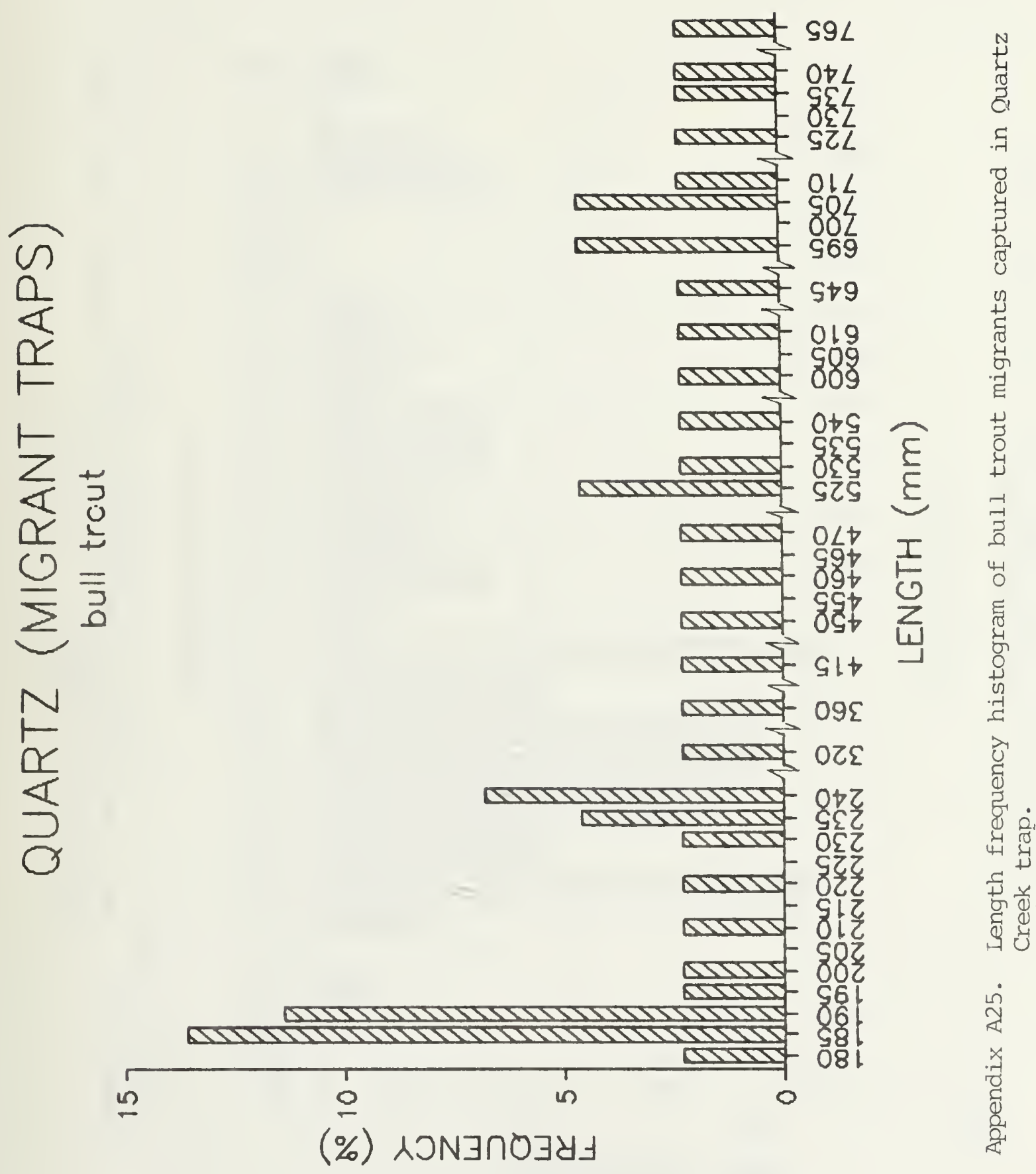

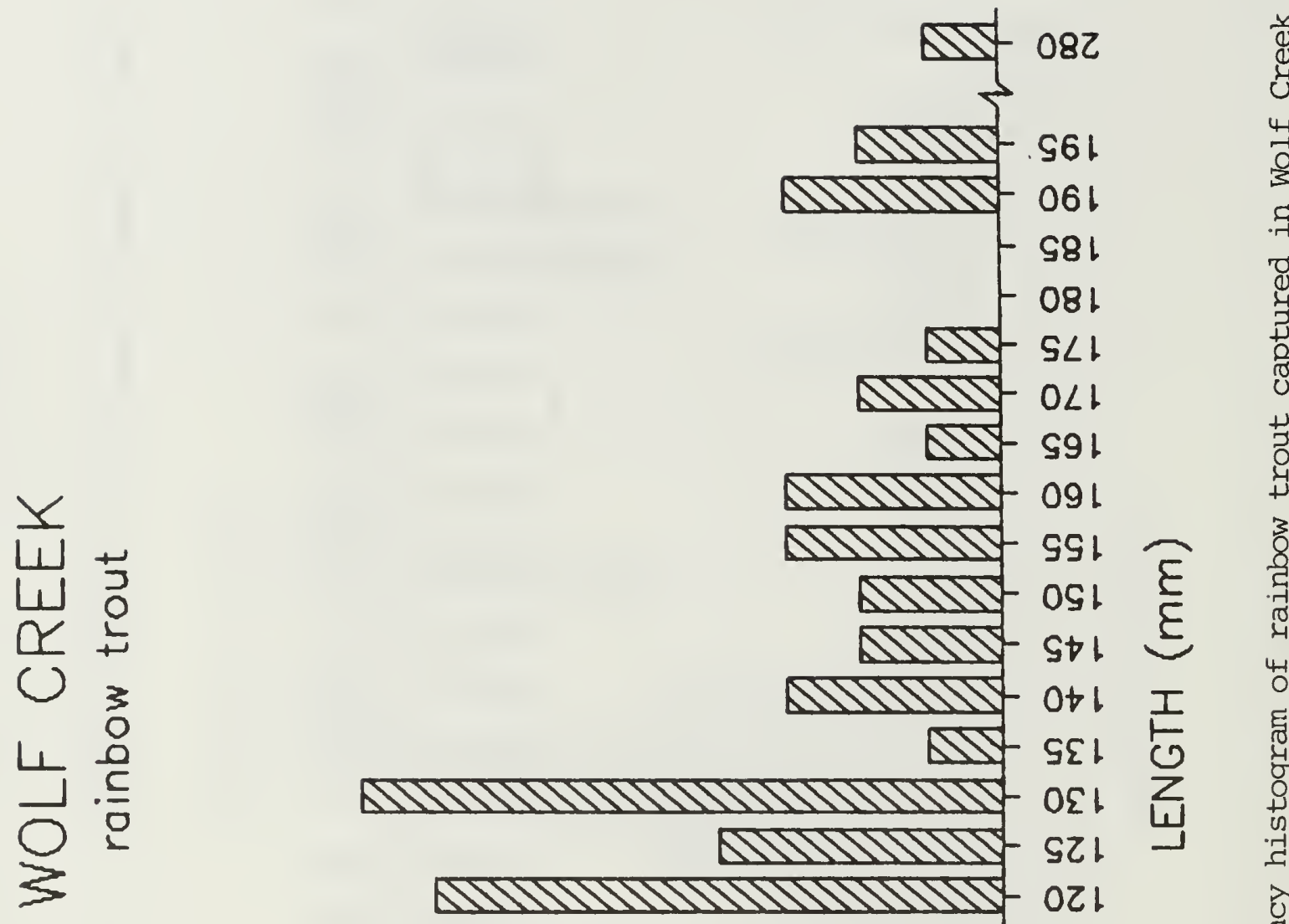

.
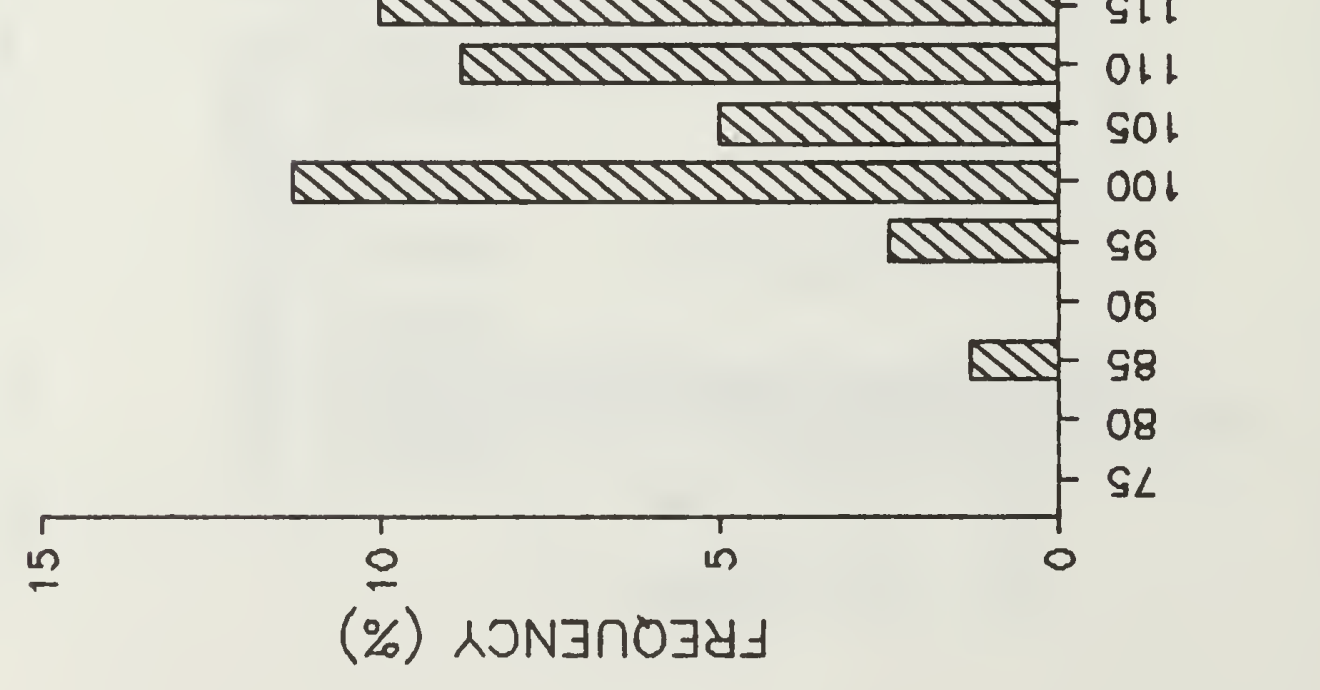

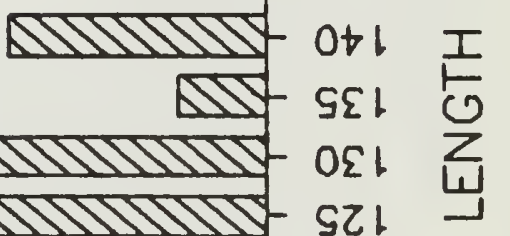




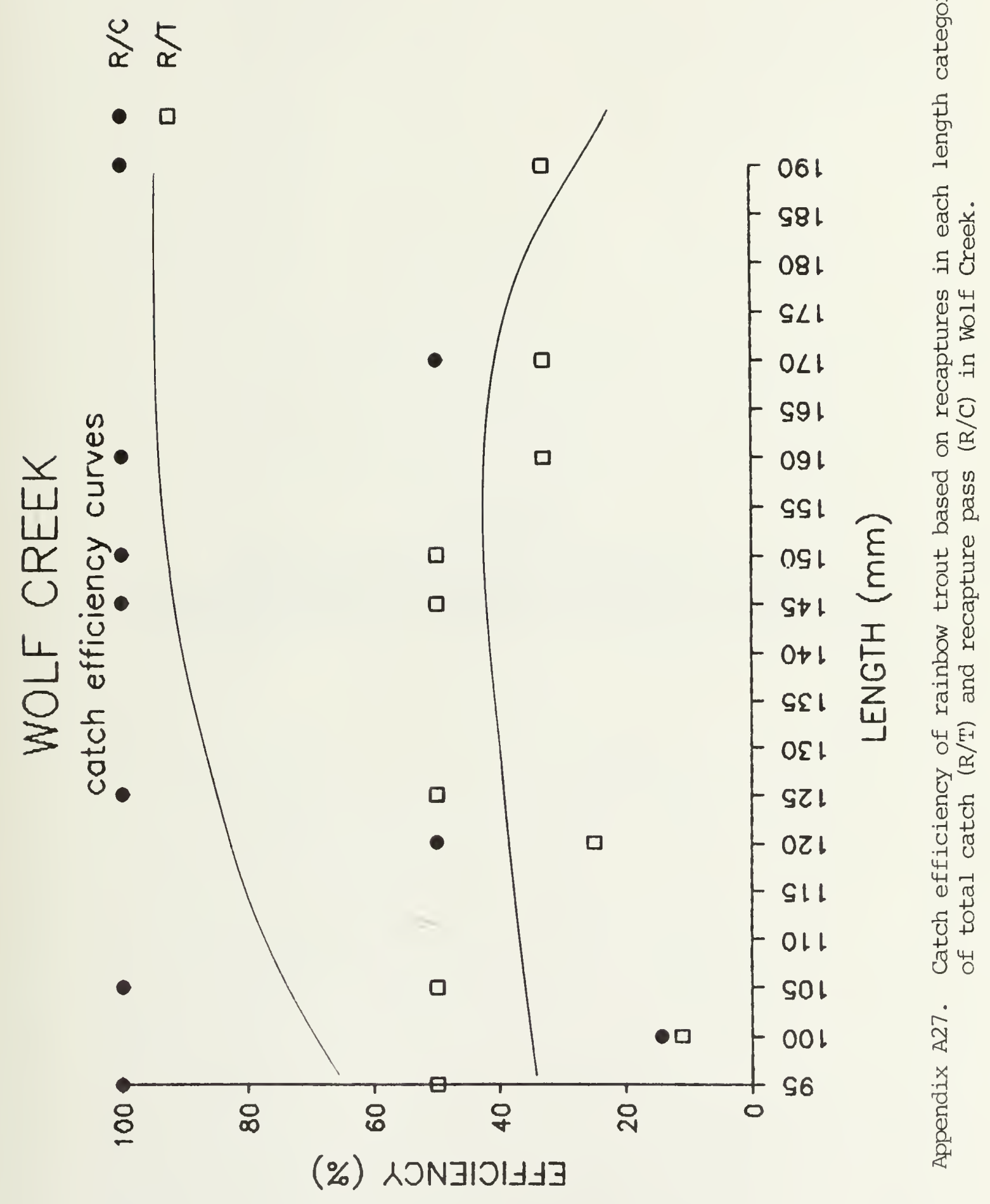





\section{APPFNDIX B}

Flow recommendations for tributaries to the Kootenai drainage and Clark Fork drainage required for successful migration, spawning and rearing of game fish 



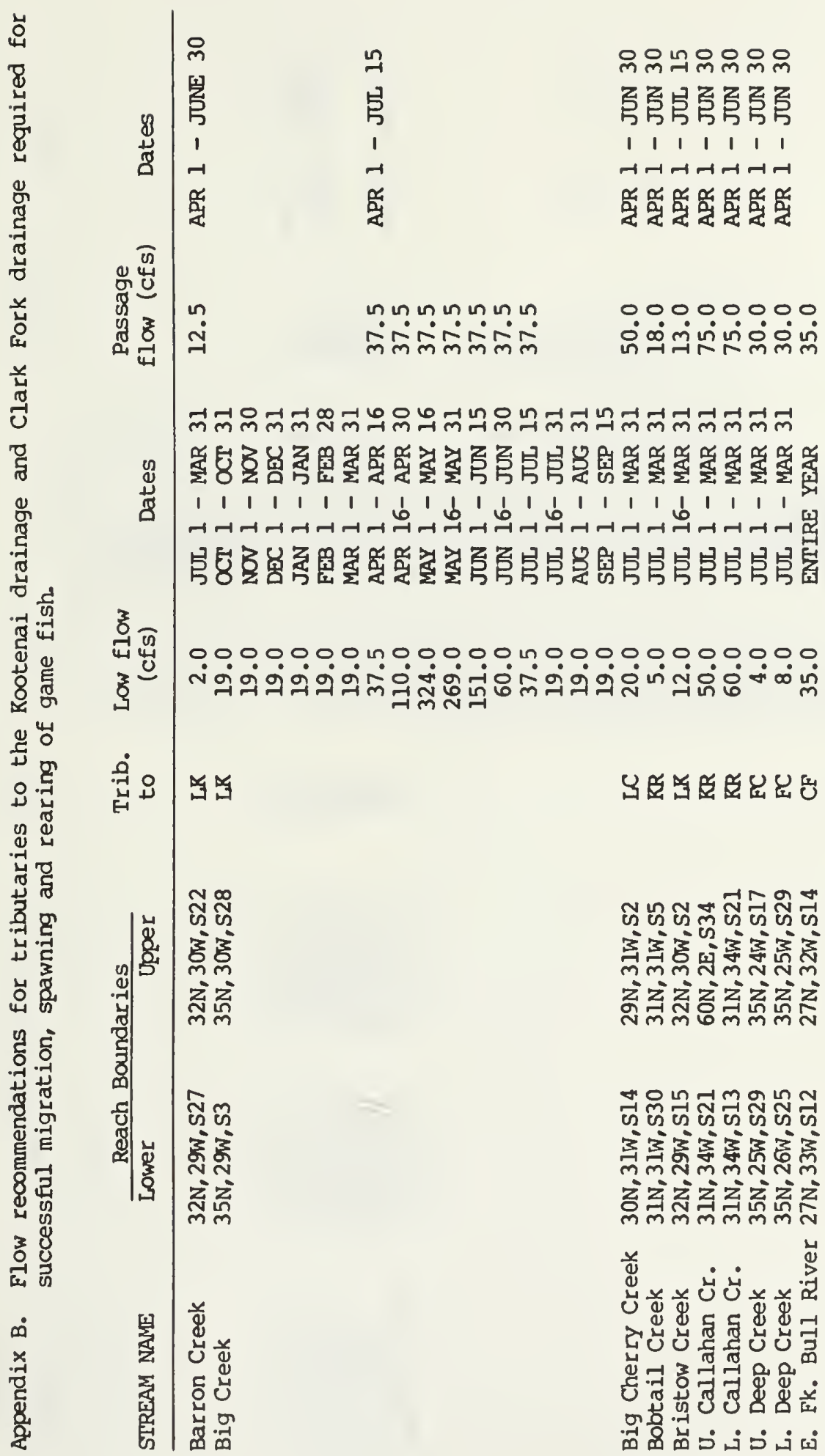




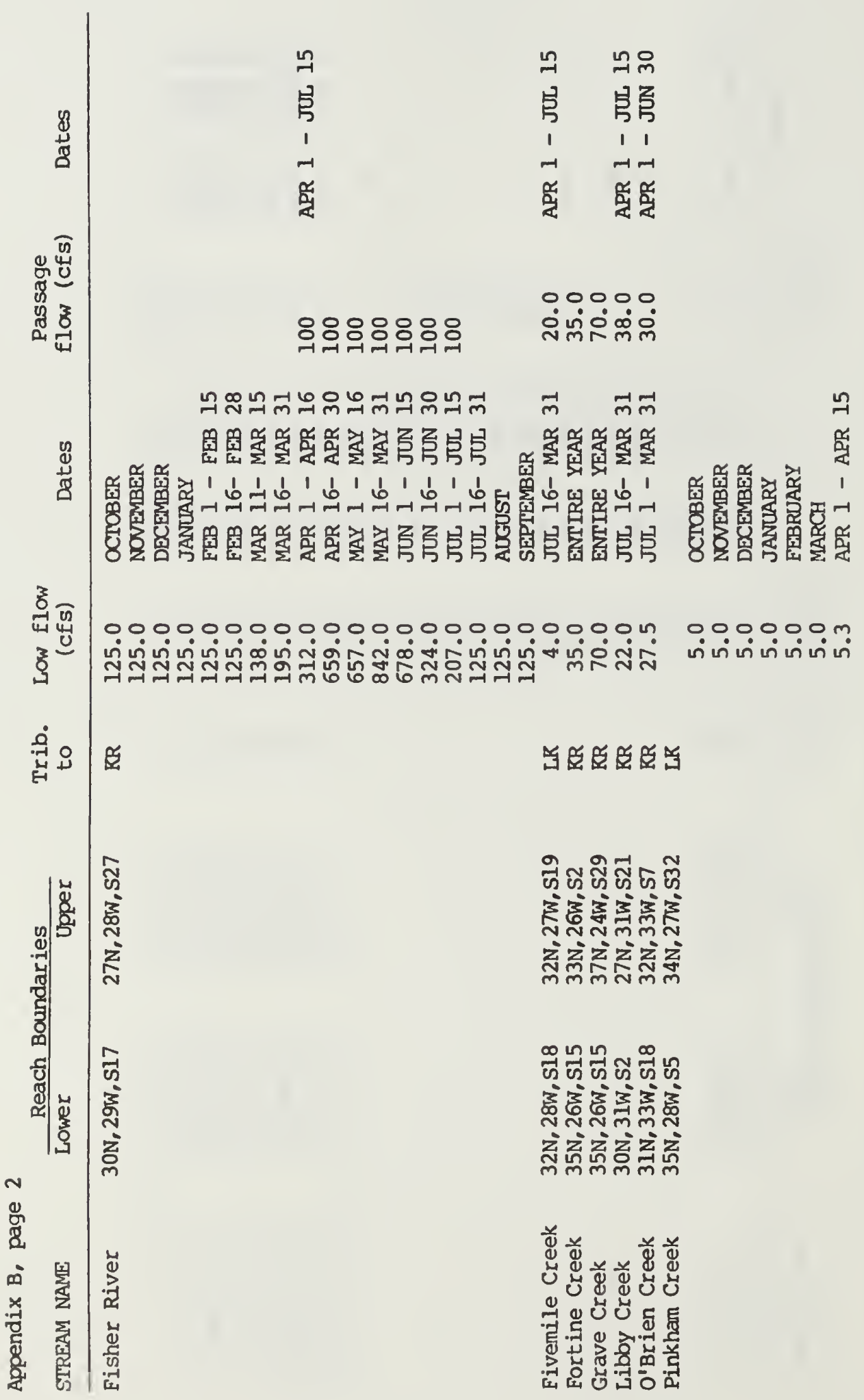




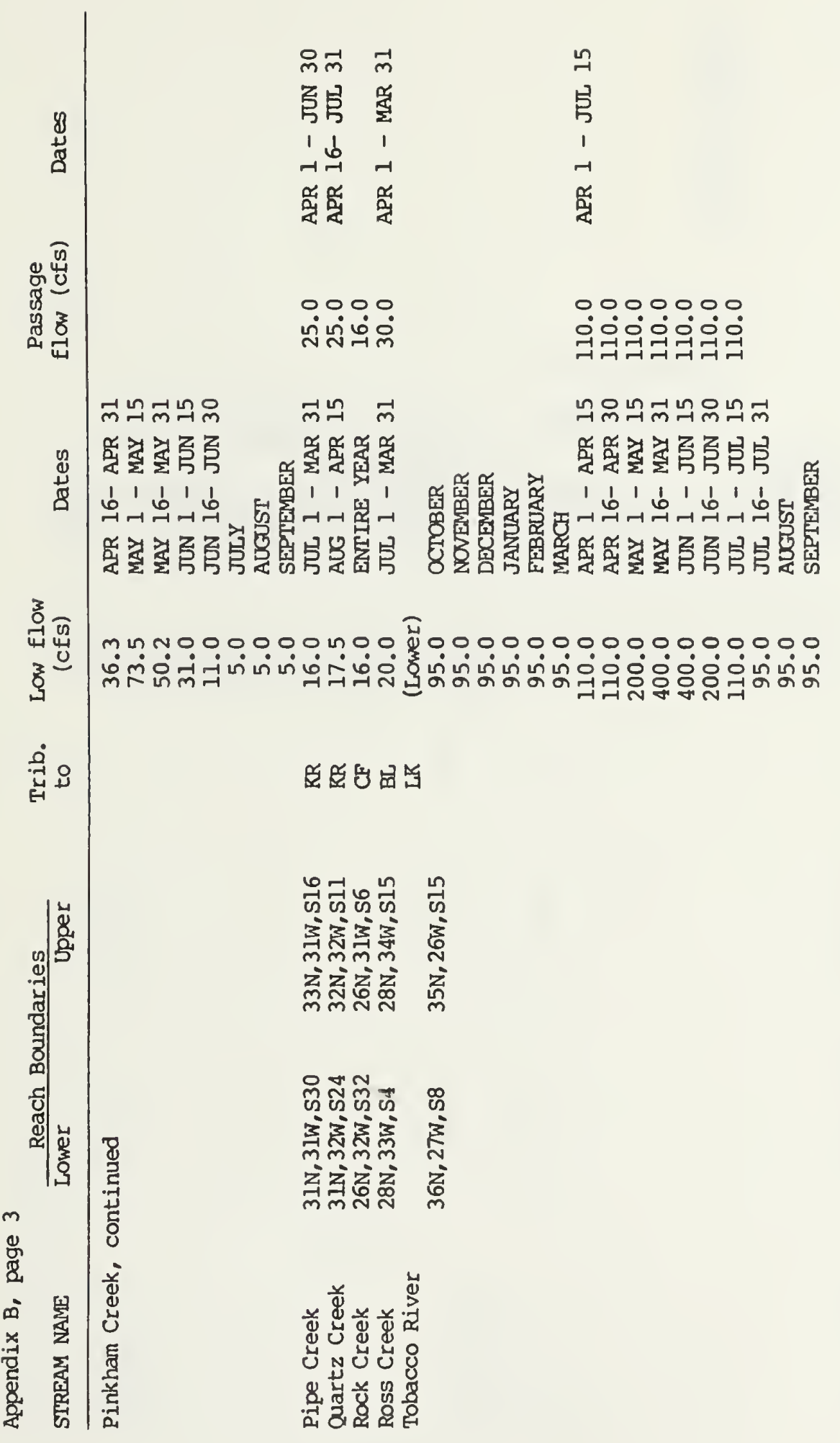




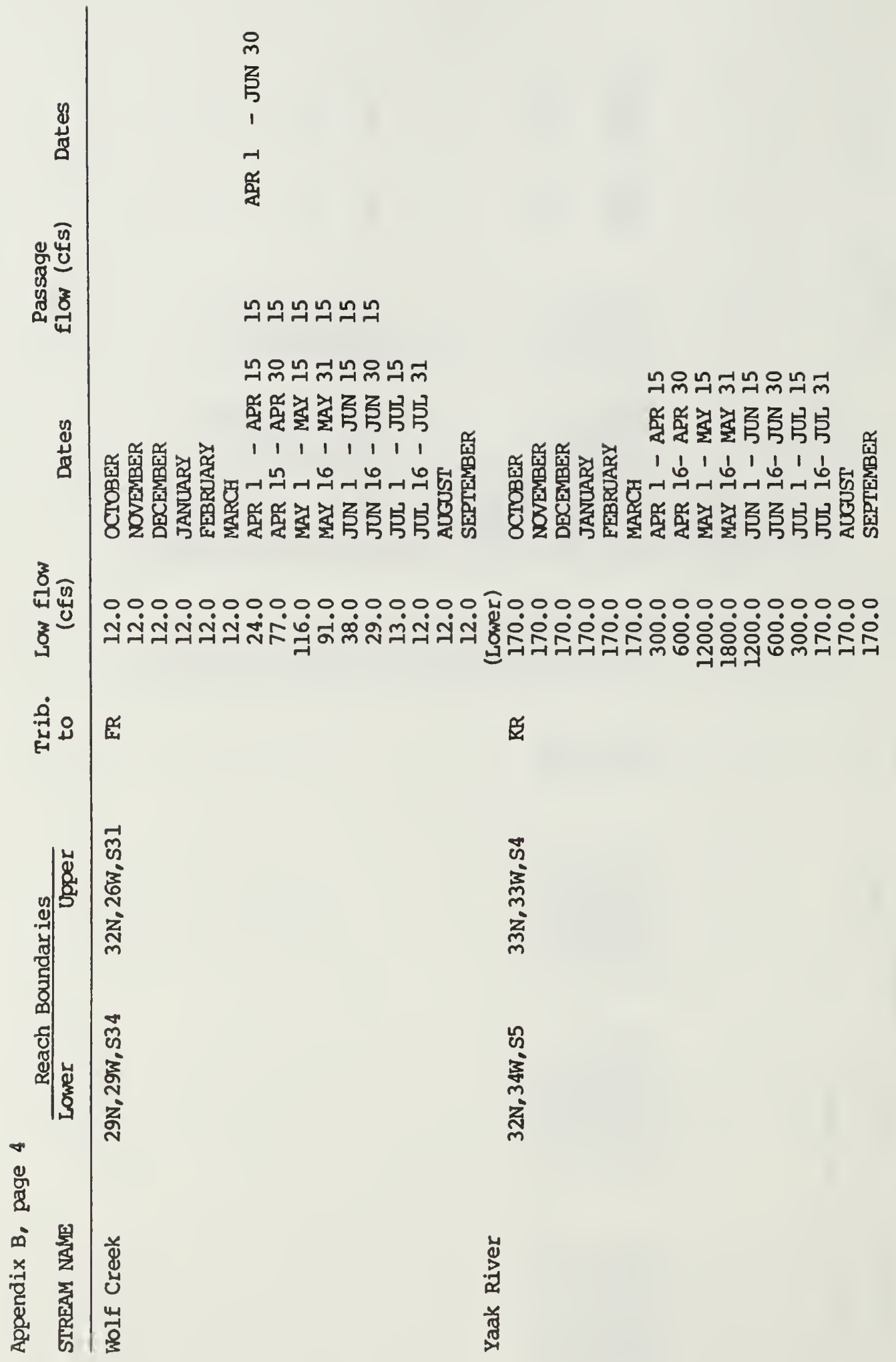




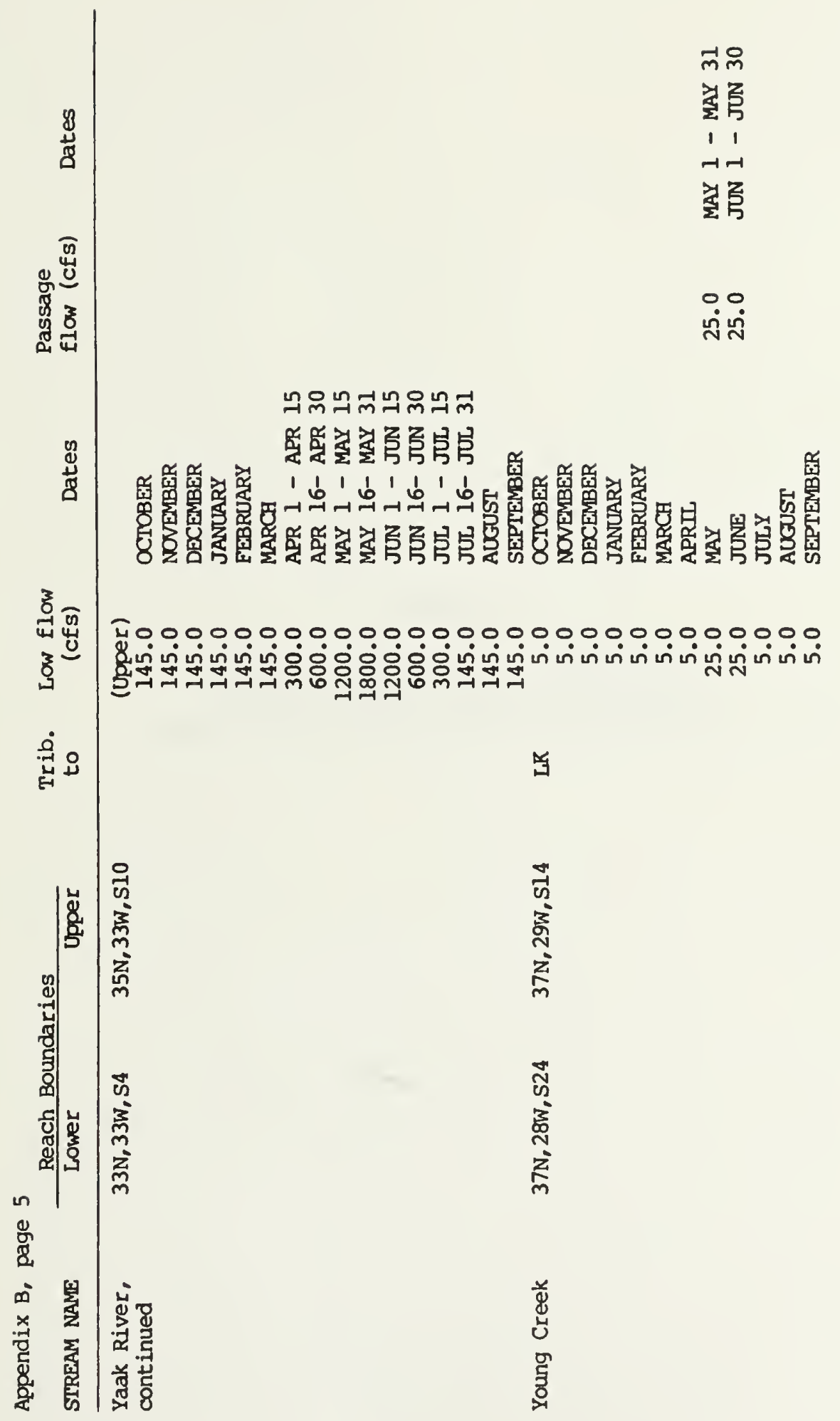





\section{APPENDIX C}

Fishery infonmation, compiled by Montana Fish, Wildlife and Parks

pertaining to streams under investigation. 


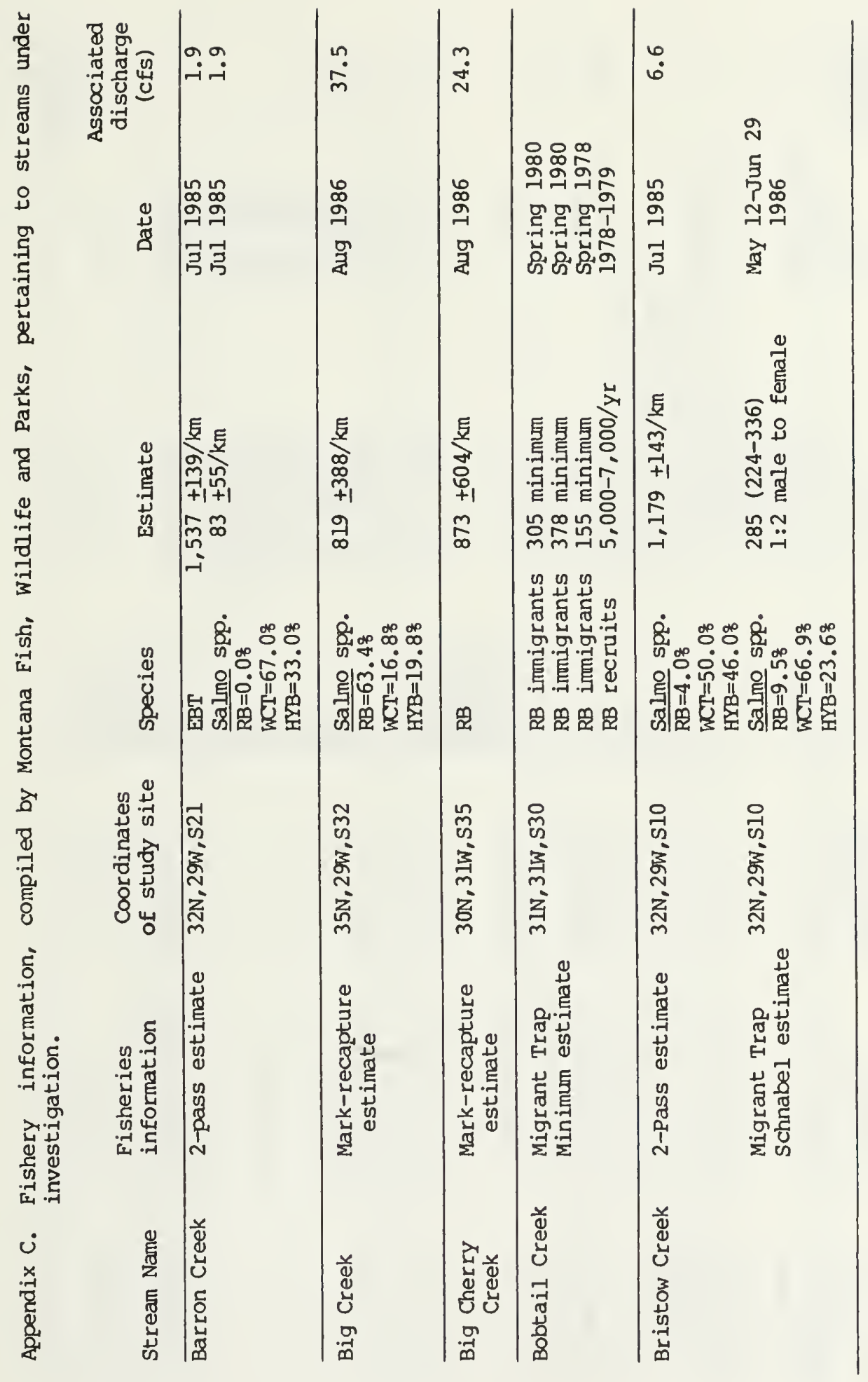




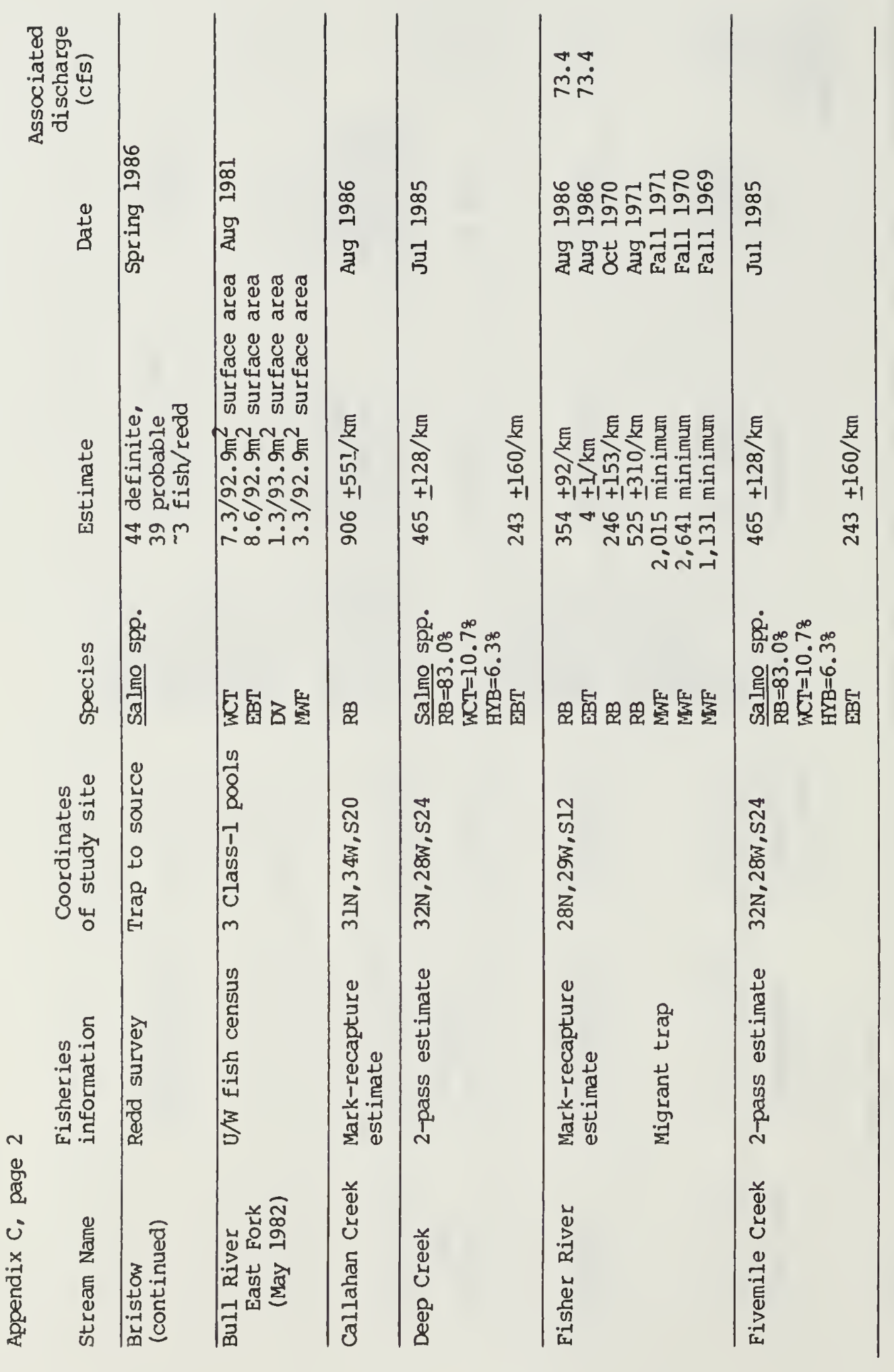




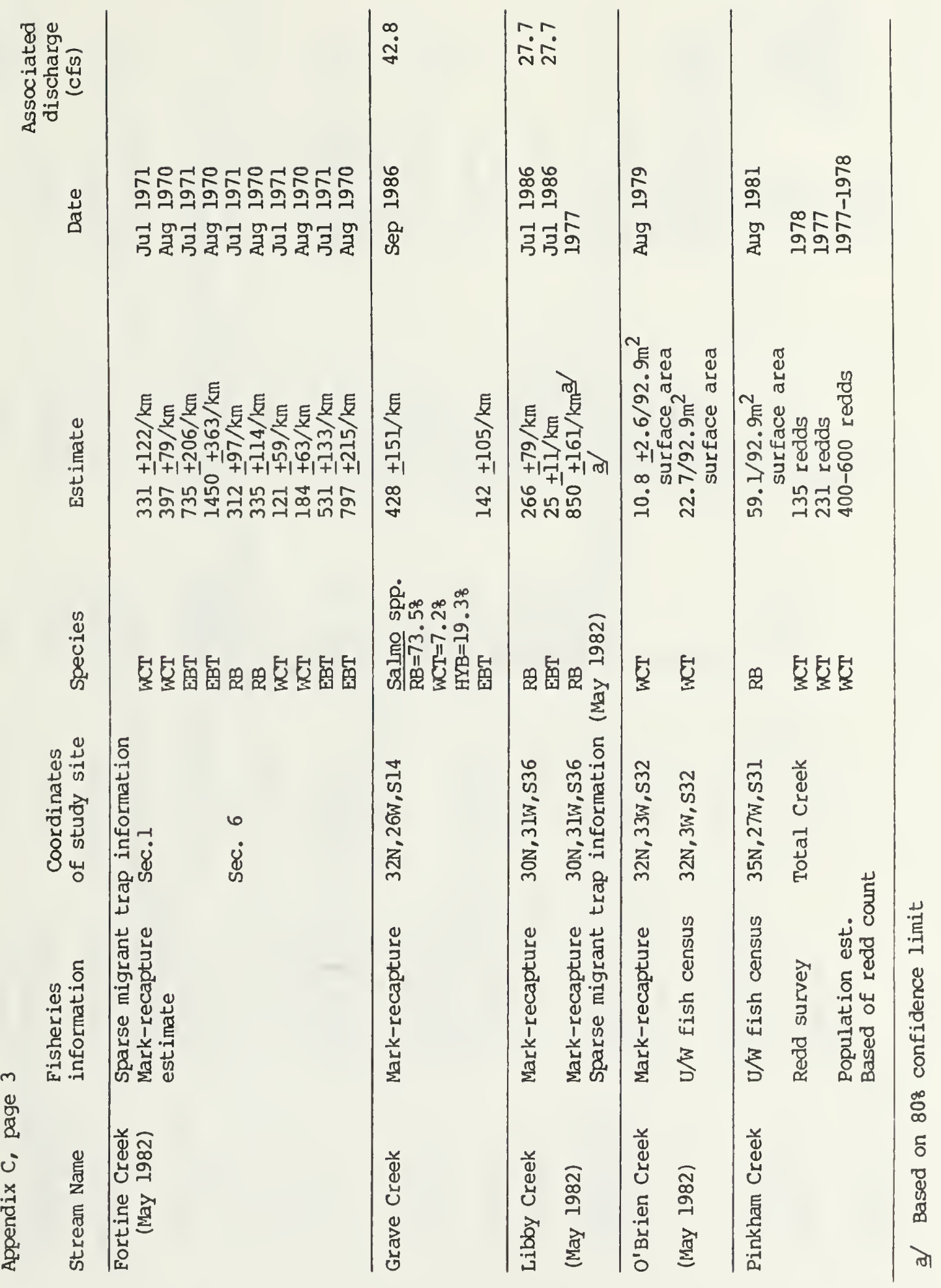




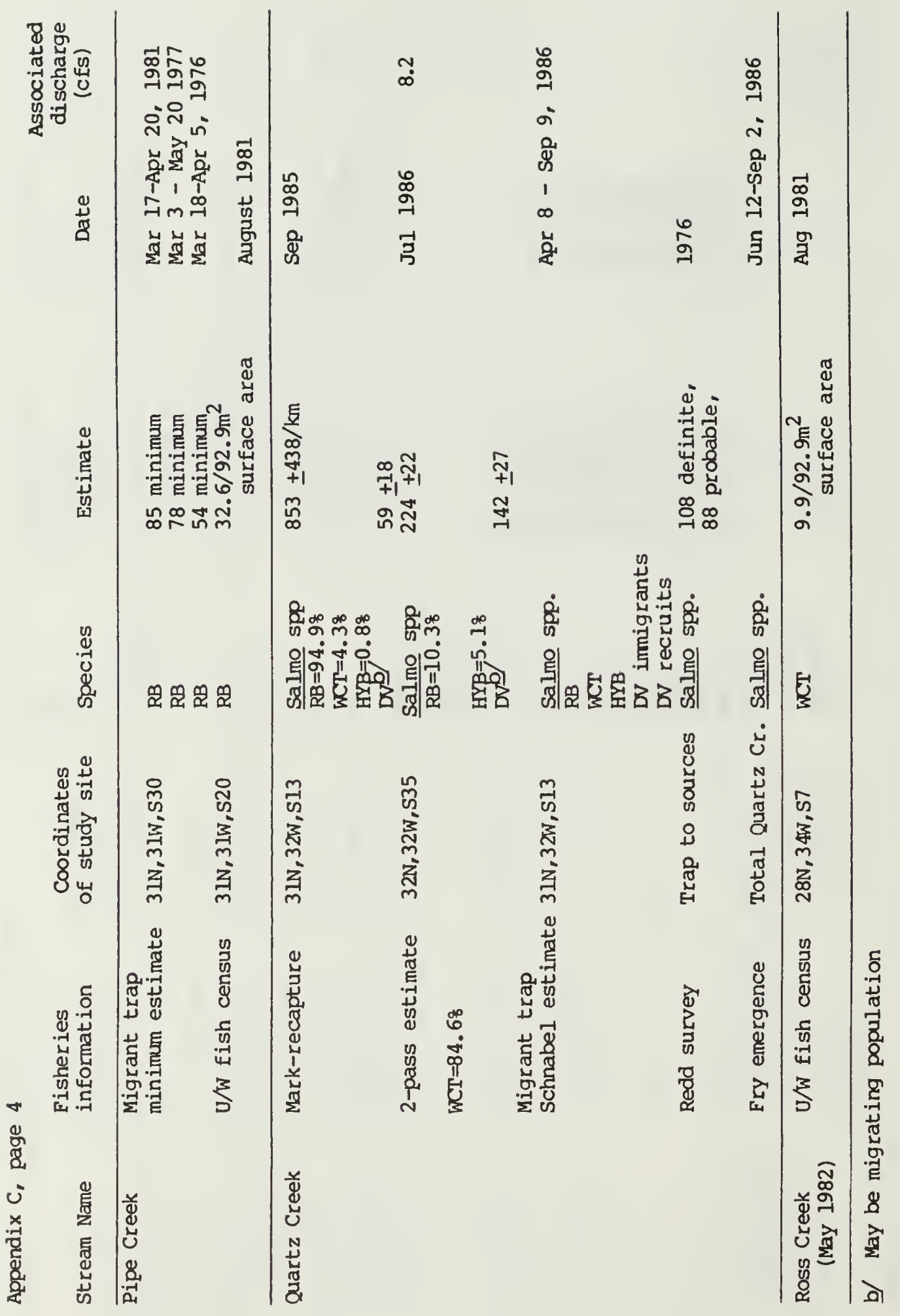




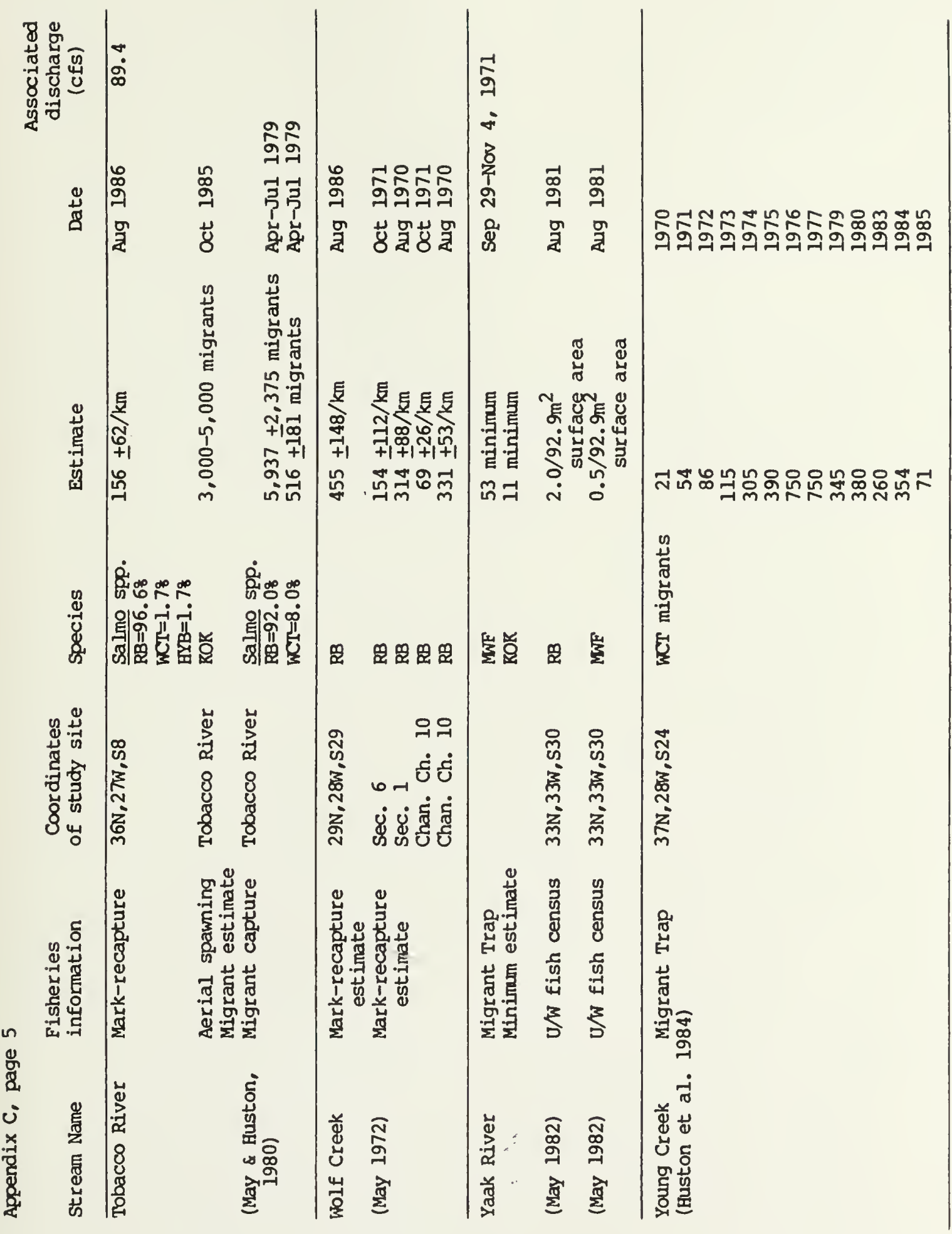




